UNIVERSIDADE DE SÃO PAULO

INSTITUTO DE PSICOLOGIA

MARIANNA DA GAMA E SILVA

\title{
O "TDAH" e os professores de escola particular: contribuições da Psicanálise
}


MARIANNA DA GAMA E SILVA

O "TDAH" e os professores de escola particular: contribuições da Psicanálise

(versão corrigida)

Dissertação apresentada ao Instituto de Psicologia da Universidade de São Paulo como parte dos requisitos para obtenção do grau de Mestre em Psicologia.

Área de concentração: Psicologia Clínica

Orientadora: Prof ${ }^{\mathrm{a}}$. Dr ${ }^{\mathrm{a}}$. Léia Priszkulnik

São Paulo

2014 


\title{
AUTORIZO A REPRODUÇÃO E DIVULGAÇÃO TOTAL OU PARCIAL DESTE TRABALHO, POR QUALQUER MEIO CONVENCIONAL OU ELETRÔNICO, PARA FINS DE ESTUDO E PESQUISA, DESDE QUE CITADA A FONTE.
}

\author{
Catalogação na publicação \\ Biblioteca Dante Moreira Leite \\ Instituto de Psicologia da Universidade de São Paulo
}

Silva, Marianna da Gama e.

0 "TDAH" e os professores de escola particular: contribuições da psicanálise / Marianna da Gama e Silva; orientadora Léia Priszkulnik. -- São Paulo, 2014.

$199 \mathrm{f}$.

Dissertação (Mestrado - Programa de Pós-Graduação em Psicologia. Área de Concentração: Psicologia Clínica) - Instituto de Psicologia da Universidade de São Paulo.

1. Transtorno de Déficit de Atenção e hiperatividade (TDAH) 2. Fracasso escolar 3. Medicalização 4. Freud, Sigmund 1866-1939 5. Lacan, Jacques-Marie Émile, 1901-1981 I. Título.

RC394.M3 
Nome: Silva, Marianna da Gama

Título: O "TDAH” e os professores de escola particular: contribuições da Psicanálise.

Dissertação apresentada ao Instituto de Psicologia da Universidade de São Paulo para obtenção do título de Mestre em Psicologia.

Aprovado em:

BANCA EXAMINADORA

Prof. Dr .

Instituição: Assinatura:

Prof. Dr .

Instituição: Assinatura:

Prof. Dr .

Instituição: Assinatura:

Prof. Dr .

Instituição: Assinatura:

Prof. Dr .

Instituição: Assinatura: 
Ao meu pai, pelo amor, pelo saber e pela fé 


\section{AGRADECIMENTOS}

A Léia Priszkulnik, minha orientadora, pelos palpites provocantes, pelo respeito ao meu tempo de elaboração e por me ensinar que a Psicanálise não precisa ser complicada.

A Ilana Katz Fragelli, por quem tenho uma imensa admiração, pela incursão no estudo de Lacan e por ter me transmitido o desejo de saber.

A Leny Mrech, por ter aceito tão gentilmente ler e contribuir com este trabalho no exame de qualificação.

À minha mãe, Magda, pela força admirável, pelo exemplo de mulher em quem me espelho e pelo amor nas horas difíceis.

Ao meu pai, Roberto, meu maior orgulho, meu motivo de persistir e por me fazer acreditar que é possível comer um elefante aos pedacinhos e que uma grande caminhada se começa com o primeiro passo.

Ao meu irmão, Renato, companheiro de toda as horas, por me ensinar que a vida não precisa ser levada tão a sério.

À minha cunhada, Sandra, por me trazer de volta a fé que pensava ter abandonado e me encorajar a enfrentar os impasses da vida.

A Isabel e a Flávia, fundadoras do Trapézio, onde consigo localizar a origem das provocações que mobilizaram meu desejo e as incursões no campo entre a Psicanálise e a Educação. Agradeço também a toda a equipe com a qual trabalhei e que me ajudou a pensar em tantas questões importantes para este trabalho em nossas reuniões clínicas.

Às minhas amigas de infância Carol, Caca, Cal, Dri, Fê, Gabi, Má e Bru, por partilharem da dor, da superação e da retomada.

Às minhas amigas de "adulta" Lia, Sofia, Rê, Déia, Karina e Cris, pelos momentos divertidos tão necessários durante a escrita deste trabalho.

Ao meu grande amigo Gustavo, pela força, apoio, companhia e incentivo de retomar aquilo que tinha abandonado.

Aos meus alunos, em especial a uma pequena ruivinha, que despertou com seu brilho no olhar o que em mim estava adormecido: o encantamento e a curiosidade sobre os mistérios da vida.

À minha avó $E d d y$, pelo testemunho de uma época que me inspira, de quem tenho uma saudade sem fim.

Ao meu analista, Paulo, com quem aprendi que as escolhas dependem "só" de mim e que é preciso autorizar-se de si mesmo, pelas revelações dolorosas mas libertadoras e pelo modo como a análise me mostrou outra forma de viver a vida. 
E, se forma longa e dificil, a dor abre uma brecha para as palavras.

Virgílio, Eneida, XI, 151

Deve nutrir-se carinho por um sofrimento sobre o qual se soube construir a felicidade, repetiu muito seguro. Apenas isso. Nunca cultivar a dor, mas lembrála com respeito, por ter sido indutora de uma melhoria, por melhorar quem se é. Se assim for, não é necessário voltar atrás. A aprendizagem estará feita e o caminho livre para que a dor não se repita. Estava a crescer.

Valter Hugo Mãe, O filho de mil homens 


\section{RESUMO}

Silva, Marianna da Gama (2014). O “TDAH” e os professores de escola particular: contribuições da Psicanálise. Dissertação de Mestrado, Instituto de Psicologia, Universidade de São Paulo, São Paulo.

O objetivo deste trabalho é analisar os sentidos e significações atribuídos por professores de escolas particulares (de elite) ao Transtorno de Déficit de Atenção e Hiperatividade (TDAH). Muito já foi escrito a respeito da psicopatologização das questões escolares sob o nome de TDAH. Entretanto, poucas são as pesquisas e os estudos dirigidos especificamente à repercussão deste fato na prática dos professores - e menos ainda dos professores de escolas de elite do Ensino Fundamental 1 - e à compreensão dos sentidos conferidos por eles a este fenômeno. O modelo utilizado é o da pesquisa qualitativa em Psicanálise, e o trabalho está dividido em dois momentos: revisão bibliográfica sobre o tema, discutida criticamente, e a pesquisa de campo por meio de entrevistas semidirigidas. A condução das entrevistas e a análise dos resultados foram psicanaliticamente orientadas pelo referencial teórico freudlacaniano. Primeiramente, levantamos elementos do espaço social e epistêmico que revestem este controverso diagnóstico e quais seus efeitos sobre a subjetividade das crianças. Discutimos a diversidade clínica envolvida nesta nomenclatura, que reduz manifestações subjetivas e sociais à categoria de transtorno. Trouxemos uma reflexão do trajeto organicista do quadro de TDAH e apresentamos um contraponto entre a noção de transtorno e o entendimento de sintoma para Psicanálise como tratamento ao real da angústia. Num segundo momento, analisamos as entrevistas com as professoras e as dividimos em categorias. Constatamos que o discurso do capitalista, aliado ao cientificismo do discurso da ciência, vem trazendo uma série de consequências ao sujeito, entre as quais: transforma a educação em mais uma mercadoria a ser consumida, legitima a transferência da responsabilidade de certos valores educativos próprios às famílias para as mãos da escola, desresponsabiliza aqueles envolvidos com a educação da criança, inclusive ela própria, e subjuga o mal-estar do sujeito a alterações neuroquímicas. Analisando esses aspectos, o trabalho busca evidenciar a permeabilidade do discurso pedagógico ao discurso médico científico hegemônico. Observamos que essa "epidemia de TDAH" acaba sendo, em grande parte, engendrada por uma sociedade capitalista, calcada no consumo e no lucro e tendo como representante o poder da indústria farmacêutica. Em uma perspectiva contrária às regularidades discursivas dos ditos especialistas, as professoras entrevistadas apresentam particularidades nas condições de enfrentamento dos impasses escolares, "inventando", dia após dia, estratégias para lidar com seus alunos. Assim, este trabalho pretende, também, contribuir com um espaço de reflexão ética, visando propiciar práticas educacionais mais críticas.

Palavras-chave: Transtorno de Déficit de Atenção e Hiperatividade, TDAH, fracasso escolar, medicalização, Sigmund Freud, Jacques-Marie Émile Lacan. 


\begin{abstract}
Silva, Marianna da Gama (2014). The "ADHD” and private school teachers: contributions of Psychoanalysis. Dissertação de Mestrado, Instituto de Psicologia, Universidade de São Paulo, São Paulo.

The objective of this work is to analyze the senses and the significances assigned by teachers in private schools (elite group) to Attention Deficit Hyperactivity Disorder (ADHD). Much has been written about the issues of school psychopathology under the name of ADHD, however, there are few researches and studies directed specifically to the impact of this fact on teachers practice - and even less on elite schools teachers of elementary school - and the insight of the meanings conferred by them to this phenomenon. The model used is the qualitative research in psychoanalysis and the work is divided into two stages: bibliographic review on the subject, critically discussed, and field research through semi-structured interviews. The conduct of the interviews and analysis of the results were psychoanalytically oriented through Freud-Lacan theoretical framework. First, we raised elements of social and epistemic space lining this controversial diagnosis and its effects on children subjectivity. We discussed the clinical diversity involved in that nomenclature which reduces subjective and social events to the category of a disorder. We have brought a reflection of the organicist path box ADHD and present a counterpoint between the notion of disorder and the understanding of symptom for Psychoanalysis as a treatment to the real of the angst. In a second stage, we analyzed the interviews with the teachers and divided them into categories. We noticed that the capitalist discourse, allied to the scientificism of the science discourse has brought a number of consequences to the subject including: turned education into a commodity to be consumed, legitimized the transfer of responsibility for certain families own educational values to the hands of the school, didn't blame those involved with the child's education, including herself, and subdued the malaise of the subject to neurochemical changes. Analyzing these aspects, this work seeks to demonstrate the permeability of pedagogic discourse to the hegemonic scientific medical discourse. We observed that this "epidemy of ADHD" ends up being largely engendered by a capitalist society grounded in consumption and income, having for major elective representantive the power of the pharmaceutical industry. On a counter perspective to the discursive regularities of said experts, the teachers who were interviewed show some particularities in terms of confrontation school impasses, "inventing" day after day, strategies for dealing with their students. This study also aims to contribute to an area of ethical reflection to provide more critical educational practices.
\end{abstract}

Keywords: Attention Deficit Hyperactivity Disorder, ADHD, school failure, medicalization, Sigmund Freud, Jacques-Marie Émile Lacan. 


\section{SUMÁRIO}

INTRODUÇÃO

1. PERCURSO HISTÓRICO E HIPÓTESE ETIOLÓGICA

1.1 A construção do TDAH

1.2 Perspectivas críticas e a medicalização na educação.

1.3 As avaliações no contexto escolar

2. A INFÂNCIA, A ESCOLA PARTICULAR E SUAS PARTICULARIDADES

2.1 Infância como uma construção discursiva histórica .

2.2 Da modernidade à contemporaneidade: os impasses subjacentes ao lugar reservado à criança escolar.... . .46

2.3 A infância, o infantil e a Psicanálise................................................................51

2.4 Panorama histórico do surgimento da escola no Brasil .......................................58

2.4.1 A situação das escolas na Europa na época do descobrimento do Brasil .....59

2.4.2 A situação das escolas no Brasil no período colonial ...................................60

2.4.3 A situação das escolas no Brasil no período do Império ..............................61

2.4.4 O século da escola pública no Brasil 1870 - 1980 ...................................63

2.5 A escola particular de elite no Brasil: os efeitos do poder econômico.................67 
3. CONTRIBUIÇÕES DA PSICANÁLISE.........................................................73

3.1 TDAH: transtorno médico ou sintoma analítico? .............................................. 74

3.2 Contribuições de Freud e de Lacan .................................................................

3.3 O mal-estar contemporâneo e o declínio da imago paterna.................................83

$3.4 \mathrm{O}$ discurso do capitalista e o mercado de saber: mudanças na educação ...........89

3.5 O terceiro ensino de Lacan: mais-a-se-pensar .............................................97

3.6 A ética da Psicanálise: responsabilidade subjetiva........................................ 101

4. PERCURSO METODOLÓGICO_..........................................................103

5. APRESENTAÇÃO E DISCUSSÃO DAS ENTREVISTAS .......................107

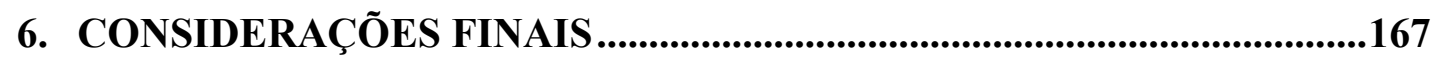

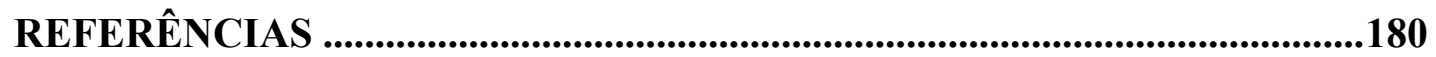

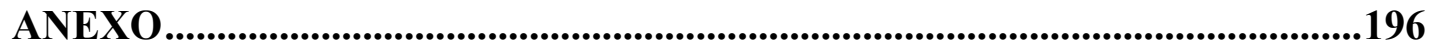




\section{INTRODUÇÃO}

O que constitui o fundo de todo drama humano... é o fato de haver liames, nós, pactos estabelecidos. Os seres humanos já estão ligados entre si por compromissos que determinaram o lugar deles, o nome deles, a essência deles. (Lacan, 1985, p. 248)

Questões preliminares

As inquietações que animam esta dissertação partem da constatação de que em nossa época crianças consideradas agitadas, bagunceiras e desatentas são vistas com preocupação dentro das escolas e agrupadas segundo essas referências na denominação de um dos transtornos com maior destaque nos encaminhamentos médicos. Crianças e jovens inquietos e com dificuldade de atenção são facilmente identificados com o diagnóstico de Transtorno de Déficit de Atenção e Hiperatividade, mais conhecido pela sigla TDAH. Trata-se do transtorno infantil mais frequente e difundido atualmente (seguido do transtorno desafiador opositivo e do transtorno de conduta), que se reproduz de forma extensa e sistemática, tendo recebido nos últimos anos uma quantidade vertiginosa de investigações a respeito de sua causa, diagnóstico e tratamento ${ }^{1}$. Livros sobre o assunto alcançaram a categoria de bestsellers, manchetes circulam em revistas e jornais do mundo todo e assistimos a uma explosão na venda de medicamentos para tratar esse transtorno ${ }^{2}$. Nunca houve um caminho tão curto para se chegar a um diagnóstico, que se apresenta banalizado como uma oferta comum para a nomeação e enquadramento da angústia que se manifesta na contemporaneidade ${ }^{3}$.

\footnotetext{
${ }^{1}$ A prevalência do TDAH em crianças em idade escolar, segundo dados da página da Associação Brasileira do Déficit de Atenção (ABDA), era estimada entre 5\% e 13\% em 2011. Estes dados foram alterados em 2014 para uma prevalência de $3 \%$ a $5 \%$.

2 Reportagem da Revista Época de 2006, “Remédios demais?", discute os riscos enfrentados por crianças medicadas com Ritalina e revela que no Brasil as vendas deste medicamento triplicaram nos últimos cinco anos. Em matéria publicada em 2010 no jornal "O Estado de São Paulo", entre 2000 e 2008 o número de caixas de Ritalina vendidas passou de 71 mil para 1,147 milhão.

${ }^{3}$ Partilharemos do conceito de contemporâneo concebido pelo filósofo italiano Giorgio Agamben (2009) como uma condição do sujeito em relação à época em que vive. "A contemporaneidade, portanto, é uma singular relação com o próprio tempo, que adere a este e, ao mesmo tempo, dele toma distâncias.... Aqueles que coincidem muito plenamente com a época, que em todos os aspectos a esta aderem perfeitamente, não são contemporâneos porque, exatamente por isso, não conseguem vê-la, não podem manter fixo o olhar sobre ela" (p. 59). O autor realiza uma bela metáfora com o escuro, dizendo que "contemporâneo é aquele que mantém fixo o olhar no seu tempo, para nele perceber não as luzes, mas o escuro” (p. 62).
} 
Vemos na literatura médica e psiquiátrica inúmeras pesquisas e descrições exaustivas sobre esse transtorno. Um simples levantamento de dados realizado em maio de 2014 no site de busca Google aponta 1.020.000 resultados com a palavra-chave TDAH e 29.200.000 resultados com a palavra-chave ADHD, sigla em inglês para o transtorno (Attention Deficit Hyperactivity Disorder). A grande maioria das páginas nos leva a informações sobre o dito transtorno, discorrendo sobre causas orgânicas, maneiras de identificação e apontando para uma imensa "vulgarização" do que seria supostamente denominado pela ciência como um transtorno de base neurobiológica, que se manifesta na tríade destacada no quinto volume do Manual Diagnóstico e Estatístico dos Transtornos Mentais (DSM-V, 2013): hiperatividade, déficit de atenção e impulsividade. No DSM-IV, em vigor até então, eram estabelecidos três diferentes tipos clínicos de acordo com as manifestações comportamentais: tipo predominantemente desatento, hiperativo-impulsivo ou combinado. A partir da última edição do manual, o termo "subtipo" cedeu lugar ao termo "predomínio", indicando a apresentação de um perfil que não é mais entendido como estável e fixo.

O diagnóstico envolve: exame da criança, entrevista com os pais e um questionário enviado à escola - principal responsável por encaminhamentos! - para a coleta de informações. Este questionário $\left(\mathrm{SNAP}-\mathrm{IV}^{4}\right)$ possui 18 perguntas e deve ser respondido pelo professor ao avaliar o comportamento da criança. Ao responder afirmativamente a seis itens de um subgrupo, o diagnóstico de TDAH está feito. Questões amplas e heterogêneas compõem este material, como por exemplo: distrai-se com estímulos externos, perde coisas, comete erros por descuido, fala em excesso.

O tratamento recomendado é à base do composto químico metilfenidato, derivado anfetamínico comercializado no Brasil com o nome de Ritalina ou Concerta, associado à terapia cognitivo-comportamental (Rohde \& Benczik, 1999). Dados alarmantes apontam que o Brasil é o segundo maior consumidor de Ritalina no mundo, estando apenas atrás dos Estados Unidos, e as vendas seguem aumentando assombrosamente a cada ano. Esse medicamento, comumente chamado de "droga da obediência" por ser administrado antes ou durante o período escolar e não aos finais de semana, possui efeitos colaterais consideráveis, como apatia, insônia e anorexia, podendo chegar a causar ataques cardíacos.

Collares e Moysés (1996), em seus escritos que se tornaram referência no estudo da medicalização das dificuldades escolares, nos mostram que esse transtorno é uma construção

\footnotetext{
${ }^{4}$ Sigla para a quarta revisão do questionário de Swanson, Nolan and Pelham. Questionário construído a partir dos sintomas do DSM-IV pela Associação Americana de Psiquiatria. Recuperado em 15 de outubro de 2010, de http://www.tdah.org.br. O mesmo material segue a ser recomendado e utilizado para o diagnóstico de TDAH pelo DSM-V.
} 
que aponta de que forma o discurso médico ressoa no social com um timbre normativo, reduzindo manifestações subjetivas e sociais à categoria de transtorno. Sendo o diagnóstico essencialmente clínico, os médicos se apoiam nas alterações no comportamento como quadro sintomático exclusivo para detectar o transtorno. Psiquiatras e estudiosos de renome, como veremos adiante, afirmam, contudo, não haver provas que evidenciem a existência do TDAH e que nunca foram encontradas diferenças orgânicas cerebrais ou reações bioquímicas diferentes em crianças hiperativas.

As questões que permeiam o conceito de TDAH e sua ampla repercussão no discurso cotidiano contemporâneo tornam este um tema relevante para a nossa pesquisa, pois envolvem a discussão sobre a medicalização da educação, a valorização da descrição médica hegemônica sobre o fenômeno e o modo como isso incide na fala e no fazer dos professores. Norteamo-nos aqui por questões como: qual é a compreensão que os professores possuem sobre o TDAH? O que pensam sobre a medicalização? $O$ que é uma criança agitada/desatenta? Em que essas crianças diferem das demais? Que estratégias de enfrentamento são utilizadas em sala de aula? E em que muda a prática educativa saber ou não se há um diagnóstico?

O predomínio da ideia de que o sofrimento humano pode ser tratado quimicamente conduz a um "apaziguamento ilusório da angústia" e facilita o descompromisso e a desresponsabilização de todos com a problemática que acomete a criança, "pois se passa a acreditar, de forma mágica, que as terapêuticas medicamentosas eliminarão todo e qualquer tipo de sintoma ou de sofrimento psíquico” (Legnani \& Almeida, 2008, p. 10).

Historicamente falando, como aponta Chauí (2010), nossa ciência ${ }^{5}$ é um fenômeno social e culturalmente produzido, ainda que atualmente seja concebida de modo desconexo com sua produção. Uma informação é, portanto, tomada como verdadeira quando existe uma comunidade que a considera como tal, e isso passa pelo modo de as pessoas a utilizarem como guia de pensamento e ação. Sabemos que opiniões variam de acordo com o lugar e a

\footnotetext{
${ }^{5}$ Ao longo do texto iremos nos referir à ciência em diversos momentos e, para tanto, é preciso marcar desde já que sempre que estivermos falando de ciência, estaremos na realidade nos referindo aos resultados de suas aplicações. Importante precisar que a ciência pura e suas teorias não podem ser identificadas com sua aplicação, com a prática. Chauí (2010) faz questão de marcar esta distinção a fim de não cairmos no senso comum numa atitude conhecida por cientificismo, que mantém a ilusão de neutralidade científica. O cientificismo, afirma a autora, "é a crença infundada de que a ciência pode e deve conhecer tudo, que de fato, conhece tudo e é a explicação causal das leis da realidade tal como esta é em si mesma” (p. 357). Ao analisar estes aspectos do senso comum cientificista, Chauí (2010) destaca: a ideologia da ciência na contemporaneidade, que com seus conhecimentos seria capaz de explicar completamente a realidade e manipulá-la, e a mitologia da ciência, enquanto detentora de verdades atemporais, absolutas e inquestionáveis. Ambas atitudes "encaram a ciência não pelo prisma do trabalho do conhecimento, mas pelo prisma dos resultados (apresentados como espetaculares e miraculosos) e sobretudo como uma forma de poder social e de controle do pensamento humano" (p.358).
} 
época em que foram emitidas. Ou seja, aparentes verdades inquestionáveis nada mais são do que fatos culturais e coletivamente condicionados, que se tornam reais no pensamento de determinada época. Morbidades que marcaram épocas e foram científica e socialmente legitimadas simplesmente desapareceram.

Scliar (2007), médico sanitarista especialista em saúde pública, nos traz um excelente exemplo da época da escravidão. Naqueles tempos, o desejo de fuga dos escravos era considerado uma enfermidade mental e recebia o nome de "drapetomania". A falta de motivação para o trabalho era chamada de "disestesia etiópica" e em ambas as situações o tratamento proposto era a chibatada. Foucault (1997), ao discutir a respeito dessa questão em A Arqueologia do Saber, conclui que a verdade instaurada pelo poder possui efeitos de poder, isso porque não há saber neutro, ele é sempre político. Consideramos importante precisar isto como ponto inicial para que possamos atuar a partir do reconhecimento desse vínculo entre verdade e poder. Assim, a constituição de um saber - no caso, o saber médico sobre a doença - conduz a detenção de um lugar de poder.

Seguindo ainda com este raciocínio, observamos que o que aparece como patológico na criança de determinada época talvez seja considerado como normal em outra. Diferentes manifestações podem ou não se configurar num quadro psicopatológico a depender da dimensão e da conjuntura socioeconômica e cultural vigente. No passado, por exemplo, as epilépticas eram queimadas na fogueira por estarem possuídas, "loucos" eram aprisionados em camisas de força e asilados, e judeus, durante o nazismo, eram torturados por não pertencerem à raça superior, tudo isso validado por médicos (Fernandéz, 2001). É preciso, portanto, analisar historicamente as práticas médicas considerando todas as determinações que as suportam e que extrapolam a própria instituição médica ${ }^{6}$.

Tomando esse ponto como referência, é importante levantar e considerar as questões na história relativas ao sentimento de infância e à relação do adulto com esses seres "pequenos", no sentido de desmistificar diversas ideias arraigadas muitas vezes como sentenças. Atravessamentos contemporâneos nos incitam a escutar o lugar designado às crianças na modernidade e as implicações de um discurso que a toma como depositária de sonhos e de uma completude da qual não se quer abrir mão.

\footnotetext{
${ }^{6}$ No capítulo 3, num momento oportuno, discorreremos sobre a lógica do que vemos acontecer hoje em dia, com o deslocamento do poder médico às indústrias farmacêuticas e os resultados desta operação: passando pelos lucros exorbitantes dos laboratórios medicinais, o "incentivo" e "apoio" dos mesmos a determinadas associações e médicos, até a própria "criação" de doenças e transtornos. Apenas para citar um exemplo desta sobredeterminação, vemos em uma reportagem publicada no jornal "Folha de São Paulo", em março de 2012, a seguinte manchete: Indústria influencia manual de psiquiatria: na equipe que prepara o novo livro de transtornos mentais (lançado em maio de 2013), 69\% dos integrantes têm relação com laboratórios (Garcia, 2012).
} 
Assistimos a uma homogeneização e padronização dos modos de pensar e agir, e quem não se enquadra é rapidamente rechaçado e recebe um diagnóstico por ser portador de um desvio. Quem determina esse padrão? A partir de quê e por quê? Tais questões não podem ser desprezadas em favor da patologização de formas de comportamento. Assim, como afirmam Collares e Moysés (2011), ao tratarmos aspectos complexos e sofisticados, como cognição e comportamento, é fundamental aprendermos a interrogar e refletir, pois é nessa área que o ser humano expressa sua maior diversidade.

\section{Provocações psicanalíticas}

Cada época busca seus recursos para dar conta do mal-estar que a caracteriza e de afrontar o impossível do ato educativo, que é estrutural, como revela Freud (1937) quando fala sobre as três profisssões impossíveis ${ }^{7}$. A medicação é atualmente o recurso que a ciência e a tecnologia produziram e com ela tenta-se responder aos sintomas das crianças de hoje. Essa atitude demonstra porque a medicalização é tão bem aceita atualmente, uma vez que, como apontam Collares e Moysés (1996), responde aos anseios de uma sociedade que busca rapidamente extirpar aquilo que causa incômodo e atrapalha o funcionamento das coisas. Por outro lado, a desatenção e a hiperatividade são formas de expressar esse "impossível" da educação e não deixam de ser também modos de o sujeito não se deixar tomar completamente pelo Outro $^{8}$ que o convoca, lançando mão do sintoma para tratar de seu sofrimento e de se afirmar. Discutiremos no trabalho a sintomatologia do TDAH, compreendendo-a a partir da Psicanálise como uma forma de expressão de conflitos psíquicos resultantes de uma configuração de significantes por meio dos quais a criança se constitui.

Extrapolaria os alvos deste trabalho apresentar os precedentes históricos da clínica médica positiva como um modelo de diagnosticar e propor tratamentos. Mas vale sublinhar que em ocasiões passadas a Psiquiatria ao menos buscava estabelecer um diálogo entre o

\footnotetext{
${ }^{7}$ Para Freud, educar, analisar e governar são as três profissões impossíveis, pois resultam sempre num mal-estar por não corresponderem ao ideal. O exercício da práxis traz o inevitável confronto com a impossibilidade de garantir que o resultado possa ser previsto antecipadamente. Como aponta Freud "os resultados serão insatisfatórios" pois o ponto de chegada nunca reitera o de partida (Freud, 1925,1937).

"Há dois outros que se devem distinguir, pelo menos dois - outro com "A" maiúsculo e um outro com "a" minúsculo, que é o eu. O Outro, é dele que se trata na função da fala." (Lacan, 1954-55/1985, p. 297). Lacan marcou uma distinção e a grafou entre o pequeno e o grande Outro; o pequeno outro é o igual, o semelhante, e o grande Outro é o campo simbólico da linguagem.
} 
saber médico e o saber psicanalítico a respeito dos significados dos fenômenos ligados à saúde e à doença. O que assistimos, desde o final do século passado, é que a visão organicista e biologizante domina o discurso científico e social, apoiado no tripé psicofarmacologia, neurociências e genética, deixando a Psicanálise de lado e se deixando contaminar por um viés de fatores externos à ciência.

Indispensável lembrar que a psicofarmacologia moderna foi quem forneceu à Psiquiatria recursos por meio dos quais esta última veio a firmar o exercício de sua prática e ganhar prestígio. A criação da classe do TDAH no manual diagnóstico psiquiátrico nada nos diz acerca da relação da criança com a aprendizagem, de sua constituição subjetiva. Para isso, há que se fazer distinção entre o mal real e sua construção social, visto que "não há classificação que não seja arbitrária e conjuntural" (Borges, 1974, citado por Bekerman, 2011, p. 26).

Para além da função estatística, as mudanças do DSMs ao longo do tempo passaram a omitir qualquer informação relevante sobre o sujeito, em prol de um referencial estritamente neurobiológico, na busca de sinais objetivos e mensuráveis, quase que isentando a necessidade de escuta do paciente.

Buscaremos ao longo do trabalho circunscrever e nos deter na questão de por que a Psicanálise pensaria sobre o TDAH e com o que ela poderia contribuir para a reflexão sobre esse suposto diagnóstico. Abordaremos o TDAH apresentando inicialmente o contraponto entre a compreensão médica científica de transtorno e o entendimento da Psicanálise de sintoma. Os eixos teóricos descritos como declínio da imago paterna e desbussolamento, conceito forjado por Jorge Forbes $(2010$, 2012), serão utilizados por favorecer a compreensão do TDAH. Discutiremos ainda de que modo o conceito de discurso do capitalista de Lacan nos auxilia a pensar sobre como essas manifestações vêm sendo compreendidas atualmente no interior das escolas.

Vemos que a Educação está atravessada pelo discurso dos especialistas de modo abrangente. Isso nos leva a interrogar a partir de que posição muitos professores olham a criança e que lugar é outorgado a ela na contemporaneidade. Também indagamos o que induz à suposição de que determinados comportamentos infantis devam ser encaminhados a médicos especialistas que diriam como educar uma criança e como podemos enxergar a permeabilidade da escola ao discurso da ciência.

Finalmente, algumas derivações do terceiro ensino de Lacan nos fornecerão suporte teórico para refletir sobre o TDAH. Iremos nos deter no entendimento desse transtorno como marca representante dos impasses pedagógicos contemporâneos e do mal-estar atual na Educação. Para isso, partiremos da cultura contemporânea, caracterizada pelos não sensos e 
vazios que aparecem e que geram um mal-estar sintomático nos sujeitos - mal-estar este imposto pelo registro do $\operatorname{Real}^{9}$, que escapa da inteligibilidade proposta e defendida pela ciência e que insiste em não se deixar apreender. Tais efeitos deletérios da cultura produzem o apagamento do sujeito. Isso comparece nas escolas como um sintoma coletivo que se reflete na medicalização desenfreada e nos diagnósticos de TDAH que se multiplicam.

Concluímos convocando a ética da Psicanálise, que busca escutar o mal-estar do sujeito e torná-lo responsável por assumir a sua posição de sujeito na vida, alternativa capaz de fazer frente ao discurso da ciência imperante. A Psicanálise vem para afirmar que o sujeito humano não se limita ao biológico e para fazer resistência contra as pretensões da ciência que "reduzem o pensamento a um neurônio ou confundem o desejo com uma secreção química" (Roudinesco, 2000, p. 9). Como pontua Birman (1999), essa sedação indiscriminada da angústia humana por intermédio dos psicofármacos representa um marco da atualidade e merece atenção especial, pois não implica o sujeito em sua problemática.

Importante precisar que não se trata de recusar a prescrição e o uso dos medicamentos em qualquer circunstância, mas sim de alertar sobre os efeitos de um discurso que, ao tomar o orgânico como causa, encerra e silencia qualquer pergunta pela verdade que o sintoma possa enunciar.

Conforme o levantamento bibliográfico realizado, verifica-se que nas escolas aquilo que nos anos 60 e 70 era entendido como um problema relativo a questões emocionais, resultando no encaminhamento da criança ao psicólogo ou psicanalista, a partir dos anos 80 passa a ser tratado pelos psicomotricistas e psicopedagogos, e que nos dias de hoje, quando há algum problema o psiquiatra e o neurologista é que são comumente procurados. Uma postura mais biológica é notada entre os vários profissionais ligados à Educação, o que nos faz pensar que algo pode ter a ver com a urgência, uma vez que o tratamento psicanalítico demanda um tempo muito maior quando comparado à ação dos medicamentos.

Pretendemos mostrar que não se trata apenas de um diagnóstico que nos leva a investigar sua terminologia e etiologia, senão a ideologia que está em jogo quando pensamos na criança que é aceita na contemporaneidade. O imperativo do desempenho que rege nossa modernidade (e sua pedagogia), conforme aponta Kupermann (2011), facilmente conduz ao risco de tratar crianças à base de Ritalina quando não correspondem ao ideal de criança que se tem em conta - o que resultará inevitavelmente numa falência, pois o ideal estrutura-se em

\footnotetext{
${ }^{9}$ A respeito do conceito de Real em Lacan é fundamental dizer que este não equivale a realidade concreta. É mais um registro através do qual o sujeito acede à realidade, sendo os outros o registro do simbólico e do imaginário. O real é aquilo sobre o qual não se tem como dizer, que não pode ser apreendido pelas palavras, que extrapola. Lacan deu o nome de real ao "'resto' impossível de transmitir" (Roudinesco \& Plon, 1998, p.646).
} 
torno do impossível, daí o seu nome, e a criança idealizada narcisicamente jamais corresponderá à criança da realidade. Tais considerações nos levam a interrogar a prática diagnóstica habitual dentro das escolas para pensá-la - e questioná-la - a partir da Psicanálise.

Presenciamos crianças, famílias e professores submetidos ao domínio da prática médica e da atuação medicamentosa sem que seus mal-estares e sofrimentos possam ser escutados e considerados. De acordo com Coutinho, Mattos, Schmitz, Forte e Borges (2009), os professores, de modo geral, frequentemente são os primeiros a sugerir que a criança tem TDAH, o que reforça a importância do relato deles, da reflexão crítica sobre o dito transtorno, visando práticas e posturas mais éticas em relação ao modo como os comportamentos e sofrimentos infantis vêm sendo compreendidos na contemporaneidade.

A administração de medicamentos às crianças para tratar um suposto transtorno orgânico, o enquadramento sob o diagnóstico de TDAH e as implicações decorrentes disso para a prática pedagógica cotidiana são fenômenos carregados de sentidos e significações para os professores, embora exista uma lacuna nos estudos dirigidos a este assunto, que buscam resultados que possam vir a ajudá-los. Quando o que é medicado é a angústia, é preciso saber o que do entorno social da criança está sendo medicado e com que pais e professores contamos. Tomar a Psicanálise como referencial teórico é balançar certezas e "devolver ao sintoma sua dignidade", torná-lo "digno oponente" como nos alerta Freud (1914b/1996) a respeito dos sintomas neuróticos.

Inúmeros trabalhos da literatura científica mostram que as diversas, e por vezes controversas, opiniões sobre o TDAH resultam em confusão para os professores. Em uma pesquisa com professores brasileiros de alto nível socioeconômico, Coutinho et al. (2009) identificaram um baixo conhecimento destes acerca da sintomatologia do TDAH, concluindo ser preciso investir em sessões educacionais e treinamentos informativos sobre o transtorno para aprimorar a capacidade de identificar crianças com possível TDAH.

Considerações como estas evidenciam a urgência de interferir em tal lógica, de se contrapor e procurar fazer com que esses profissionais do campo educativo possuam uma postura crítica e ética, com a qual possam questionar a atual medicalização das manifestações subjetivas. Ao oferecer um espaço de escuta psicanalítica, no qual os professores possam se confrontar com suas crenças a respeito da criança com TDAH, com os significantes que marcam o seu fazer e com a corrente prática da medicalização, que de forma alguma possui efeitos unívocos, pensamos ser possível propiciar práticas mais críticas em sala de aula no momento de realizar algum encaminhamento ou até mesmo de preencher o questionário SNAP-IV, tendo o bom senso de recusar dissociar o orgânico do cultural e do psíquico. 
Destacamos neste momento uma consideração importante do motivo da escolha de professores de escolas particulares como amostra eleita para a nossa pesquisa de campo. Verificamos que as pesquisas nas escolas são, predominantemente, em escolas públicas e os estudos sobre as questões do fracasso escolar em escolas particulares são ainda escassos e muito recentes. Acreditamos que isso esteja relacionado à grande preocupação em relação às questões do fracasso da escola pública, que tanto evoca a atenção da população em geral e que desvia a atenção daquilo que vem se passando neste outro polo. Além disso, interessamonos em escutar o que vem se passando no interior dessas escolas de elite, quais as lógicas que sustentam os encaminhamentos realizados por seus professores, os quais lidam com situações bastante "privilegiadas", quando comparadas ao que se passa na escola pública.

Enfim, a partir de nossa reflexão, entendemos que para além da designação TDAH existem os efeitos sociais sobre a subjetividade e a incidência na instituição escolar. Pretendemos contribuir para a promoção de uma aposta do poder educativo sobre o discurso medicalizante acerca do sofrimento das crianças e que este possa incluir o campo da palavra e do saber das autoridades educativas sobre suas responsabilidades pedagógicas e intervenções que ocorram dentro do mesmo dispositivo.

Outra preocupação, tratada pela historiadora e psicanalista Elizabeth Roudinesco (2000), diz respeito ao que ela chama de "era da individualidade". Vivenciamos, segundo a autora, uma política de evitação dos debates sobre as controvérsias, o que deixa o sujeito numa posição de conformismo e submissão, na qual não mais demanda ser escutado. Crianças se escondem atrás de diagnósticos, professores preferem o curto caminho do encaminhamento médico diante do aluno que não corresponde ao "ideal", e famílias recorrem a especialistas para resolver e silenciar rapidamente uma situação conflituosa.

Tendo tecido essas considerações, este trabalho teve por objetivo central buscar e analisar os sentidos e significações atribuídos por professores de escolas particulares de Ensino Fundamental I ao Transtorno de Déficit de Atenção e Hiperatividade (TDAH). Os objetivos específicos decorrentes da pesquisa foram: escutar o relato dos professores frente ao TDAH; permitir que eles manifestem o que pensam sobre a corrente prática diagnóstica e medicamentosa; dar a oportunidade para que expressem o que os faz levantar a hipótese de que determinada criança tenha TDAH; e contextualizar aspectos específicos de determinada classe social no enfrentamento dos impasses presentes no processo de escolarização. Assim, para escutar os professores, foi planejada a pesquisa de campo. 
No primeiro capítulo, apresentaremos o trajeto histórico da criação do que hoje é chamado de TDAH e sua hipótese etiológica. Partiremos do esclarecimento necessário sobre esse suposto transtorno e quais as representações que jazem por detrás dessa sigla. Trataremos da questão da medicalização de questões escolares a partir de uma perspectiva crítica levantada por autores consagrados na área. Para isso, discorreremos sobre o modo como esse transtorno vem sendo compreendido e discutiremos ainda as avaliações no interior das escolas, desde o seu surgimento no campo pedagógico até as repercussões nos dias de hoje. Mostraremos como a Psiquiatria Infantil nasceu da convergência dos interesses profiláticos da Medicina com as exigências disciplinares do Estado.

No segundo capítulo, incorreremos na definição de infância e de infantil e trataremos de apresentar a escola particular sobre a qual estaremos nos referindo, destacando aspectos singulares de sua constituição. Partiremos do debate inaugurado por Ariès sobre o surgimento da infância para deslizar na compreensão do lugar dedicado à criança na modernidade, articulando-o às revelações freudianas sobre a criança e o infantil. Ao refletir sobre a cultura e as vicissitudes da educação, a Psicanálise abre um campo para discussão acerca - também da posição ocupada pelos adultos diante das crianças na contemporaneidade, posição esta entre a paralisia e a desresponsabilização. Para que possamos nos referir à escola particular de elite, cujos professores são alvo deste trabalho, tratamos de situar o surgimento das escolas no Brasil e as modificações ocorridas ao longo da história.

Posto isso, remetemo-nos a referências bastante atuais e específicas sobre a escolarização da elite, assunto explorado apenas recentemente, visando a busca de ferramentas e argumentos de análise da pesquisa de campo. Propomo-nos o desafio de investigar em meios sociais favorecidos todas essas questões que envolvem a extensa incidência do diagnóstico de TDAH, pensando no modo como os privilégios ligados ao favorecimento econômico podem virar trunfos perante os fracassos escolares. Colocaremos em questão algo que usualmente não é discutido e que diz respeito ao papel do capital econômico na definição de como muitos assuntos são tratados no campo educativo, bem como as implicações disso para o sujeito e para a sociedade.

No terceiro capítulo, traremos as contribuições da Psicanálise como eixo teórico privilegiado para se pensar sobre as decorrências do diagnóstico de TDAH. Primeiramente apontaremos o contraponto entre a compreensão médica científica de transtorno e o entendimento de sintoma para a Psicanálise como a melhor resposta do sujeito para tratar sua angústia, para, a partir daí, discorrer sobre o corpo "hiperativo" e "desatento". 
O corpo biológico é análogo ao organismo objetivado que é investigado em suas funções e disfunções pela Medicina, enquanto que o corpo na Psicanálise não equivale ao organismo, mas sim a um corpo erógeno e pulsional, onde está inscrito o olhar do outro. Trata-se de um corpo tecido e humanizado pela linguagem. Abordaremos o TDAH a partir da compreensão psicanalítica que pode entendê-lo como um sintoma que está a serviço da afirmação da singularidade do sujeito.

A seguir, para dar continuidade à discussão sobre as questões que envolvem o conceito de TDAH e sua ampla repercussão no discurso cotidiano contemporâneo, com a valorização da descrição médica hegemônica sobre o fenômeno e o modo como isso incide na prática educativa dos professores, buscamos conceitos psicanalíticos para dar sustentação teórica à análise das entrevistas. Para isso, conceitos descritos por Freud e Lacan serão apresentados, uma vez que eles nos permitem comentar a consideração do referido fenômeno como resposta ao mal-estar contemporâneo e por oferecerem instrumentos de leitura das entrevistas realizadas. O declínio da imago social paterna e o discurso do capitalista nos servirão como operadores de leitura para pensar sobre como tais manifestações vêm sendo compreendidas atualmente no interior das escolas e sobre o modo como a Educação está atravessada pelo discurso dos especialistas de modo abrangente, produzindo uma série de consequências.

No quarto capítulo, descreveremos o método de investigação que embasa este trabalho, sendo ele o modelo de pesquisa qualitativa. Esta dissertação de mestrado está assentada numa pesquisa cujo referencial teórico e ético é o da Psicanálise. Em relação à análise das entrevistas, após sucessivas leituras e escutas do material foi possível realizar alguns recortes e levantar pontos de ancoragem para discutir os dados encontrados. O material está separado por temas e categorias através de questões que se repetem e também por singularidades e modos particulares de enxergar e lidar com a questão do diagnóstico de TDAH. Tal estratégia de análise foi escolhida devido à repetição de alguns assuntos e para facilitar a apresentação dos resultados encontrados.

No quinto capítulo, apresentaremos a análise das entrevistas colhidas na pesquisa de campo, buscando enfocar qual é o papel dos professores na compreensão e no encaminhamento das vicissitudes da criança e destacando ainda aspectos que entendemos ser próprios às escolas particulares de elite no tratamento das dificuldades escolares. Os seguintes eixos foram escolhidos para a discussão: o que os professores têm buscado? O que é a criança agitada e desatenta? Serão todas as crianças de hoje desatentas? Como as professoras manejam os impasses em sala de aula? Estratégias de enfrentamento. Afinal, quem é a criança 
com TDAH? Entre o esperado e o inesperado, somos todos TDAH? Mal-estar contemporâneo na Educação e suas implicações. Ritalina "Concerta"? Causalidade: imagem da criança. E, finalmente, qual o lugar do diagnóstico e diagnóstico para quê(quem)?

Teceremos as considerações finais no sexto capítulo, levantando questões a respeito dos motivos que sustentam uma postura medicalizante no campo educativo, considerando, no entanto, um achado "inesperado" quando comparado com a literatura pesquisada e que diz respeito à inventividade dos professores entrevistados e às estratégias de enfrentamento dos impasses escolares, que se apresentam das mais variadas formas. 


\section{PERCURSO HISTÓRICO E HIPÓTESE ETIOLÓGICA}

O cotidiano nas escolas nos coloca frente a um mal-estar, que se manifesta no alto número de crianças tidas como portadoras do que hoje é chamado de Transtorno de Déficit de Atenção e Hiperatividade. De modo intrigante, é raro que não encontremos em alguma sala de aula ao menos uma criança com suspeita ou de fato portadora desse diagnóstico. Antes de pensarmos numa epidemia de doenças mentais que estaria acometendo as crianças no interior das escolas - já que os dados de prevalência dessa doença e os números de caixas de medicamento para tratá-la poderiam nos levar ingenuamente a isso ${ }^{10}-$, consideramos mais prudente pesquisar a história do surgimento do TDAH.

É provável que a apresentação seja familiar àqueles que estão envolvidos no campo da Educação de alguma forma. Ainda assim, partiremos dessa ampla revisão bibliográfica sobre o tema, pois ela nos permitirá discutir a medicalização das dificuldades escolares, a qual pretende reduzir o sujeito a centros corticais e sinapses nervosas. O apelo sistemático do discurso médico hegemônico numa tentativa incessante de controle busca, cada vez mais, observar, medir, avaliar e classificar tudo aquilo que resiste ao ideal social de adulto. Iremos discutir ainda neste capítulo como as avaliações surgiram no interior das escolas e o motivo da perpetuação de tais práticas nos dias de hoje.

\subsection{A construção do TDAH}

Ao examinar textos de diversos autores sobre o assunto, verificamos que o TDAH nada mais é do que um significante novo para algo muito antigo, em que convergem interesses de pesquisadores e efeitos da ciência e do mercado. A investigação sobre as raízes científicas desse suposto transtorno revela um terreno com certas distorções, criação de fatos e omissões, distantes em muito do rigor metodológico preconizado pela ciência.

\footnotetext{
${ }^{10}$ Apresentamos na introdução deste trabalho, em nota de rodapé, os dados referentes ao volume de vendas de caixas de metilfenidato ao longo dos anos. Encontramos ainda dados do Instituto Brasileiro de Defesa dos Usuários de Medicamentos (IDUM) que divulgam que de 2000 a 2010 subiu de 70.000 para 2.000.000 o número de caixas vendidas. A Agência Nacional de Vigilância Sanitária (ANVISA), divulgou em fevereiro de 2013 o aumento de $75 \%$ referente à prescrição de Ritalina nos três últimos anos, alertando para uma supermedicação.
} 
As primeiras descrições médicas sobre o referido transtorno surgem ainda no fim do século XIX. Adam Rafalovich (1970), em seu livro Framing ADHD Children, nos apresenta uma análise crítica sobre a história e o discurso social vinculado à construção e legitimação do TDAH e revela que esse transtorno esteve inicialmente relacionado ao discurso médico sobre a criança idiota e o imbecil moral. O conceito de hiperatividade possui seus antecedentes na "criança turbulenta" (Wallon), na "instabilidade psicomotora" (Ajuriaguerra), na "síndrome hipercinética" (Abramson), entre outros (Tendlarz, 2006; Ajuriaguerra, 1983). Desde o início dos anos 60, a chamada instabilidade psicomotora esteve associada a formas anormais do comportamento, não raro sendo vista socialmente como perversão (Ajuriaguerra, 1983). Em 1925, escola francesa veio a apresentar, com o trabalho de Wallon, um outro posicionamento a respeito da instabilidade motriz, ao considerá-la do ponto de vista psicológico da personalidade do instável psicomotor.

Porém, segundo Ajuriaguerra (1983), os autores que escrevem na língua inglesa demonstraram desconhecer os estudos em língua francesa sobre psicomotricidade e criaram a síndrome hipercinética, localizando-a no quadro dos distúrbios da conduta e do comportamento e formulando hipóteses patogênicas para ela. Marcelli (1982, 1998), em seus estudos que deram continuidade ao trabalho de Ajuriaguerra, apontou a instabilidade psicomotora como um dos grandes motivos de consulta em Psiquiatria Infantil. Segundo o autor, na maior parte dos casos tratava-se de meninos e a queixa vinha da escola, acompanhada das seguintes frases: "ele não para", "mexe em tudo", "não ouve nada", "está sempre voando" - características idênticas ao que hoje é aceito como sintoma de TDAH. Vale a pena pontuar que o autor já havia alertado sobre o risco de a criança desenvolver uma “instabilidade reativa" como resposta à intolerância do meio e a suas exigências inacessíveis: "A vida urbana atual não é muito adaptada às necessidades de catarse motora da criança" (Ajuriaguerra, 1983, p. 83).

Em 1947, a corrente anglo-saxônica desenvolveu uma concepção neurológica segundo a qual os distúrbios de comportamento e de aprendizagem das crianças estariam relacionados à existência de uma suposta "lesão cerebral mínima" (LCM). A semelhança entre as sequelas comportamentais em crianças atingidas por traumatismos cranianos ou encefalites infecciosas e os sintomas de hipercinesia e desatenção observados em inúmeras outras crianças fez com que os autores supusessem que era "lógica" a existência de uma LCM em crianças desatentas e/ou agitadas (Marcelli, 1982/1998). Inicialmente, pensava-se que o dano cerebral era mínimo demais para causar outras manifestações neurológicas, mas suficiente para alterar apenas o 
comportamento e as funções cognitivas. Mesmo não passando de especulação, essa hipótese foi publicada sem qualquer evidência empírica.

Devido às críticas a tal concepção, um grupo de estudos realizado em Oxford em 1962 constatou que não havia lesão alguma. Portanto, o erro deveria ser apenas conceitual, por se tratar de uma disfunção. Com isso, o mesmo quadro passou a ser denominado como “disfunção cerebral mínima” (DCM) (Collares \& Moysés, 1996; Ajuriaguerra, 1983).

Essa mudança terminológica apareceu num momento crítico de questionamento sobre a ausência de evidência. Entretanto, vemos que a hipótese continuou a mesma. Em seus escritos que se tornaram referência no estudo da medicalização das dificuldades escolares, Collares e Moysés (1996) apontam ainda que o TDAH teve como origem o chamado quadro de "dislexia específica de evolução", que nada mais é do que uma suposição que inverteu a lógica da causalidade presente nas investigações a respeito da dislexia. A observação de que pessoas que passaram por traumas neurológicos tinham como sequelas alterações no comportamento e na leitura/escrita (quando comparados com seus próprios padrões anteriores à doença) levou a uma inversão reducionista dessa lógica ao supor que pessoas com comportamentos tidos como fora do padrão deveriam, então, apresentar uma disfunção cerebral.

Vemos mudanças aparentes, mascaradas por novas nomenclaturas, falando de um mesmo suposto distúrbio neurocerebral que acometeria a criança em nível orgânico e cujas características seriam:

a) acometer apenas o comportamento e aprendizagem, justamente as áreas mais complexas e de maior complexidade à avaliação no ser humano; b) critérios subjetivos, vagos. . . e sem número mínimo de sinais, de modo que preencher um critério apenas já era suficiente para fazer o diagnóstico; c) ausência de sinais ao exame físico e neurológico; d) ausência de alterações em qualquer exame laboratorial. . . e com um remédio à disposição da indústria farmacêutica. (Collares \& Moysés, 2011, p. 77)

$\mathrm{Na}$ trajetória de construção do TDAH, encontramos um personagem que foi relegado por questões óbvias, mas que deixou importantes marcas na hipótese etiológica deste quadro. Trata-se de Bradley, neurologista americano que em 1937 realizou experimentos com crianças de orfanato, dando-lhes anfetamina e concluindo que crianças com problemas de comportamento e aprendizagem melhoravam significativamente com a ingestão dessa droga experiência antiética que foi abafada, deixando atrás de si a conclusão de que "problemas de comportamento" deveriam ser tratados com anfetamina, fazendo assim com que crianças 
saudáveis fossem inseridas no território da dependência química através da prescrição de medicamentos (Collares \& Moysés, 2011).

Em 1957, o quadro foi descrito como a "síndrome do impulso hipercinético", caracterizando-se por seu elemento motor sem controle sobre os impulsos e com excesso de movimento, e em 1960, foi redefinido como a "síndrome da criança hiperativa" (Caliman, 2010). Em 1971, a descrição das manifestações clínicas dessa entidade foi ampliada, e Wender agregou a esse diagnóstico a hiperatividade, o déficit de atenção, a impulsividade, as dificuldades de aprendizagem e os transtornos afetivos (Tenderlaz, 2006). Foi então que, em 1980, na terceira edição do Manual Diagnóstico e Estatístico dos Transtornos Mentais (DSM III), surgiu a "síndrome de déficit de atenção", na qual foi acrescida depois a hiperatividade. Na publicação do DSM IV, em 1994, o transtorno apareceu com distinção de tipos e foi definitivamente reconhecido como um dos problemas mais graves da saúde pública americana (Caliman, 2008).

Em maio de 2013, foi lançada a quinta edição do DSM, a qual manteve os mesmos critérios e sintomas que a edição anterior, alterando os subtipos por especificadores de apresentação e com a novidade de classificar o TDAH em leve, moderado e grave, de acordo com o comprometimento na vida do sujeito. Por fim, o transtorno foi colocado no capítulo de desordens do neurodesenvolvimento, refletindo a correlação dele com a maturação cerebral.

Apesar das sucessivas mudanças de denominação, raramente comentadas no debate público, podemos verificar que o quadro permanece o mesmo - "mudam-se as aparências, mas a carcaça continua a mesma" (Collares \& Moysés, 2011, p. 78). Contra suspeitas sobre a legitimidade do diagnóstico e a sua existência real, em janeiro de 1998 foi organizado por Russel Barkley (2002), uma das maiores autoridades no campo, um Consenso Internacional, que corroborava a evidência científica do TDAH. Buscou-se com isso confirmar a natureza biológica e cerebral do transtorno, considerado como uma condição médica real, incluindo a referência de dezenas de artigos médicos. Entretanto, o relatório explicitado pelo Consensus Development Statement on Diagnosis and Treatment of Attention Deficit Hyperactivity (1998) e publicado pelo National Institutes of Health (NIH) comenta que as hipóteses sobre alterações cerebrais continuam especulativas, que não há nada que ateste a existência do transtorno e reconhece ainda os riscos do tratamento com psicoestimulantes por períodos longos. Ainda que tal relatório date de 1998 e as descobertas da Neurociência caminhem em ritmo acelerado, vale a pena sublinhar este achado, uma vez que o Consenso foi organizado por Barkley, célebre médico defensor do TDAH e, apesar disso, obteve respostas que questionavam a existência desse transtorno. 
Hoje os critérios diagnósticos permanecem os mesmos que os da DCM, envolvendo: exame da criança, entrevista com os pais e um questionário enviado à escola. Conforme abordado na introdução deste trabalho, trata-se de um questionário intitulado SNAP-IV, que é dirigido ao professor a fim de avaliar o comportamento da criança no ambiente escolar, respondendo com um "X" de sim ou não a cada uma das 18 perguntas relacionadas. Vale lembrar que não é necessário que todos os sintomas estejam presentes para que o diagnóstico já seja definido, bastam seis. Trata-se de um material composto por questões não objetivas, tais como: frequentemente fala em excesso? Frequentemente comete erros por descuido? Frequentemente distrai-se com estímulos externos? Frequentemente é esquecido em atividades do dia-a-dia? Essas perguntas dão margem para interpretações bastante subjetivas.

Chamamos a atenção para esse questionário, uma vez que ele é reconhecido pelo DSM-V como parte integrante e crucial do diagnóstico de uma doença causada por alterações cerebrais e, no entanto, suas questões abrem margem para as mais variadas interpretações. $\mathrm{O}$ que é falar em excesso para um professor pode não o ser para outro, e o mesmo vale para as demais questões. O aluno comete erros por descuido? Em que situações? Que erros são esses? Por que são avaliados como descuido e não relacionados a qualquer outro motivo? Além do mais, a única diferença entre o comportamento entendido como "normal" e o próprio da criança com TDAH localiza-se na palavra "frequentemente". Que tipo de causa biológica é essa que reconhece a diferença entre "normal" e frequente antes de considerar um certo professor, em determinada escola e sociedade?

Não há dúvida de que se fôssemos responder sozinhos a esse questionário numa autoavaliação de nosso comportamento seguramente iríamos nos enquadrar como portadores de TDAH. Essa inevitável ironia revela a insensatez brutal de um discurso médico que se propõe a medir e a classificar com rigor científico o comportamento humano. Impossível não questionar a pretensa clareza de um discurso neurológico sobre um transtorno que já mudou de nome inúmeras vezes e que se revela nada mais do que um enorme diagnóstico "guardachuva", que acaba por abrigar em si as mais diversas e indefinidas funções e disfunções da vida de um sujeito.

Importante destacar que, dado o diagnóstico, é recomendado o início do tratamento à base de um derivado anfetamínico, comercializado no Brasil com o nome de Ritalina ou Concerta. Adiante iremos nos deter no motivo do crescimento assombroso das vendas desses medicamentos, bem como apresentar reações críticas frente à prescrição dessas drogas, que consistem em estimulantes do sistema nervoso central e podem apresentar efeitos colaterais significativos para as crianças. Numerosos estudos apontam que o metilfenidato, substância 
presente nesses medicamentos, suprime comportamentos espontâneos de brincar, explorar e socializar, além de propiciar o surgimento de comportamentos obsessivos. Crianças tratadas com Ritalina padecem frequentemente do chamado efeito "zumbi", um estado de apatia generalizada, entendido como efeito terapêutico (Jerusanlinsky, 2011).

Peter Bregguin (2002), renomado psiquiatra americano, autor de inúmeros artigos e livros entre eles Talking Back to Ritalin e The Ritalin Fact Book, alerta sobre os riscos do uso dessas drogas estimulantes - cuja composição é similar à da cocaína e que, por isso, têm com um alto poder de indução ao vício -, as quais podem causar diversos efeitos, entre eles: danos cerebrais, problemas cardiovasculares, hipertensão, parada de crescimento, psicose, entre outros. A respeito do uso destas drogas em crianças "rotuladas como portadoras de TDAH, os efeitos terapêuticos tão divulgados, sempre apresentados benéficos, constituem na verdade sinais de toxicidade das drogas", expõem Collares e Moysés (2011, p. 102).

Infelizmente, a maioria desses estudos não chega até o público leigo, que, exposto à prescrição de tais psicotrópicos, desconhece a enorme quantidade de efeitos colaterais e os riscos advindos do uso dessas drogas.

1.2 Perspectivas críticas e a medicalização na educação

Ao nos determos nas hipóteses etiológicas em torno do TDAH, encontramos uma série de estudos com contradições e fragilidade científica, como será apresentado a seguir. As explicações respaldam-se na suposição de que diversos fatores estão envolvidos na causa do TDAH. Entretanto, nenhuma pesquisa é conclusiva e os estudos não são concordantes (Legnani \& Almeida, 2008). A literatura médica aponta relatos de alterações anatômicas em diversas áreas do cérebro, o que causa espanto, pois como poderiam existir tantas alterações cerebrais e a consequência ser tão específica, causando um transtorno que acomete apenas o comportamento?

Aparecem nos trabalhos médicos afirmativas que reduzem o mal-estar ao funcionamento biológico do sujeito: "A causa do TDAH é certo desfuncionamento cerebral" ; "os estudos com neuroimagens sugerem que os cérebros de crianças com TDAH são diferentes de outras crianças"; ou ainda "o TDAH frequentemente é genético e qualquer que seja sua causa específica (o que indica que a mesma não é conhecida), parece iniciar-se muito cedo na vida à medida que o cérebro está se desenvolvendo" (Stiglitz, 2006, p. 12). 
Stiglitz, psiquiatra e psicanalista, aponta para a imprecisão de tais achados e a excessiva heterogeneidade entre os elementos descritivos, o que expõe visivelmente a veracidade científica das pesquisas em voga. Muitos artigos consultados sugerem que a etiologia do TDAH mais aceita considera que existe uma alteração de certos neurotransmissores - dopamina e noradrenalina. Essa suposição de um desequilíbrio químico - sem comprovação científica consistente - foi construída ao se verificar que os medicamentos estimulantes aumentavam o nível desses neurotransmissores, a partir do que se depreendeu que isso significava que seria o déficit dessa substância química o responsável por provocar o TDAH.

Frente a isso cabe-nos ainda perguntar, levando em conta a neuroplasticidade: será essa variação funcional no cérebro causa ou consequência do transtorno? E essa questão central é justamente algo que não se sabe (Rebasa, 2006). Surpreende ainda o fato de que a despeito de tais imprecisões o tratamento recomendado às crianças seja medicamentoso.

Ainda que os EUA sejam reconhecidos como o epicentro do TDAH, o país ocupa essa mesma posição no que diz respeito à produção científica que examina sob uma perspectiva crítica esse fenômeno. Sociólogos, pediatras, psicólogos, psiquiatras e até neurologistas vêm questionando duramente a existência genuína do transtorno e sua definição. Baughman (2006), um reconhecido neurologista americano, afirma de modo convicto que o TDAH é 100\% uma fraude. Lloyd, Stead \& Cohen (2007), no livro Critical New Perspectives on $A D H D$, revelam os mitos que rodeiam o transtorno e apresentam autores renomados em disciplinas acadêmicas distintas com suas explicações para a emergência e manutenção do TDAH em nossa sociedade - um debate que passa pelo domínio do modelo da psiquiatria americana e a necessidade de mercado das indústrias farmacêuticas, como também pela função que esse diagnóstico ocupa nas escolas, famílias e na própria sociedade.

Vários autores vêm discutindo criticamente a alta incidência do TDAH e expondo o quão inconclusivas e incertas são as ditas evidências anatomo-fisiológicas tão propagadas por vários cientistas. Ao tecer críticas ao discurso biologizante e reducionista da psiquiatria, esses autores fazem importantes objeções a respeito do modo como o sujeito vem sendo reduzido estritamente ao seu funcionamento biológico (Guarido, 2007, 2008; Collares \& Moysés, 1996, 1997, 2011; Legnani \& Almeida, 2008; Caliman, 2008, 2009, 2010; Werner, 2001, entre outros).

É importante destacar que todas essas hipóteses defendidas pelo discurso científíco devem ser lidas no contexto da tendência social de discriminar e erradicar comportamentos tidos como desviantes e fora do padrão estabelecido pela sociedade de determinada época. 
Esse padrão revela-se como um eixo central para entender porque a medicalização ${ }^{11}$ é facilmente disseminada e aceita, tendo-se difundido para o campo pedagógico e fazendo parte do imaginário de muitos professores.

O processo de medicalização tem como resultado naturalizar uma história que foi socialmente construída. No campo educativo, isso gera a patologização dos processos envolvidos nas situações de ensino e aprendizagem, pela transformação de dificuldades, que lhes são inerentes, em transtornos, com o consequente apagamento do sujeito. Assim, manifestações infantis, como agitação, não permanecer muito tempo sentado, mexer constantemente no material, falar sem esperar a vez etc., são encaradas como efeitos de disfunções neurológicas ou bioquímicas, sem qualquer relação com aspectos afetivos, sociais e culturais.

$\mathrm{Na}$ atualidade, o TDAH ganha destaque como a descrição médica mais utilizada, o que evidencia claramente a biologização das vicissitudes que comparecem na infância. O que mais espanta é a larga aceitação social desse diagnóstico, que pode ser facilmente constatado no interior do discurso pedagógico. Esse modo de entender as vicissitudes do processo de ensino-aprendizagem - individualizando, biologizando e naturalizando problemas coletivos é que é chamado de medicalização da educação, tema amplamente estudado pela professora e médica pediatra Maria Aparecida Moysés.

Como ressalta a autora, a consequência desse modo de se encarar a queixa escolar é isentar a instituição de ensino de responsabilidades, ao centrar na criança e em sua família as causas do fracasso escolar. Conforme veremos no item a seguir, o declínio da autoridade do pai (assunto discutido no Capítulo 3), bem como a substituição de sua função educativa pelos médicos (e demais especialistas), são fatores que deram grande empuxo à medicalização da infância.

É preciso deixar claro que, quando falamos de medicalização, estamos querendo pensar um movimento para além da prescrição de medicamentos. Queremos pensá-la como engrenagem de uma medicina que transforma a vida em objeto de sua intervenção. Assim, medicalizar a vida passa a significar a fabricação de subjetividades medicalizadas com a prescrição de normas e condutas para todos os níveis da existência, transformando todo e qualquer sofrimento humano em patologia. (Monteiro, 2008, p. 9)

Frente ao que foi exposto até o momento, iremos discutir adiante o que faz com que o TDAH tenha tido uma credibilidade tão expressiva, que desconsidera as controvérsias a

\footnotetext{
${ }^{11}$ Ivan Ilich denominou de medicalização o processo de deslocamento de problemas inerentes a vida para o campo médico, denunciando o aumento do poder médico sobre o modo como a sociedade vem conduzindo o sofrimento dos seres humanos.
} 
respeito de sua existência real. Entendemos que é oportuno e pertinente sublinhar que nem todos no campo psiquiátrico estão de acordo quanto à existência do TDAH. Bregguin (2002) declara não haver provas que evidenciem esse quadro e afirma que nunca foram encontradas diferenças orgânicas cerebrais ou reações bioquímicas diferentes em crianças hiperativas. Peter Conrad e Adam Rafalovich (1970/2008) apresentam uma perspectiva sociológica crítica do TDAH e vêm se dedicando há anos a estudar a influência da prática médica na vida social.

A investigação sobre o contexto sócio-histórico de surgimento e legitimação desse dito transtorno revela que a aceitação social acerca do TDAH ganhou destaque na década de 60, quando houve um grande interesse governamental dos EUA em oferecer respostas às famílias de classe média baixa a respeito do fracasso escolar de seus filhos (Collares \& Moysés, 1996). Soma-se a isso a Guerra Fria, a Guerra do Vietnã, a corrida espacial, a juventude questionadora do movimento hippie, tudo contestando valores da sociedade americana ${ }^{12}$. Nesse cenário de prosperidade econômica, foram bem aceitas as explicações médicas sobre a etiologia orgânica dos problemas de aprendizagem. Seria possível localizar os indivíduos incapazes de satisfazer as expectativas morais, políticas e econômicas da sociedade a partir de um diagnóstico médico. Esse diagnóstico se fortaleceu, portanto, no interior de uma sociedade que valoriza o indivíduo bem-sucedido e produtivo, tanto é que diversas pesquisas ocupam-se em analisar a relação do TDAH com a criminalidade, desemprego e perdas econômicas, encarando-o como um fator de risco para o estado norte-americano (Matza 2005, citado por Caliman, 2008).

Outro autor central que impulsionou a atual categoria diagnóstica do TDAH foi o pediatra inglês George Still, ao vincular, no início do século, o transtorno de atenção a um defeito neurofisiológico do sistema inibitório, o déficit da moral e da vontade (Caliman, 2010). Com suas teses, Still tratou de "legitimar os valores morais da época ao inscrevê-los no corpo", postulando a "existência de uma patologia moral específica, marcada pela desobediência às regras e consensos morais" (Caliman, 2010, p. 52). A decisão sobre a existência do distúrbio não passava de um acordo social sobre o que era ou não tolerado.

Em virtude dessas marcas, verificamos que o transtorno teve um papel considerável na legitimação do discurso neurobiológico, num processo de biologização e patologização da moral e da vontade, cujos problemas passariam a ser resolvidos por meio do tratamento médico e não pelo aprendizado de um autocontrole, por exemplo.

\footnotetext{
12 Hannah Arendt (1957/1997) realiza colocações preciosas para pensar sobre a crise do mundo moderno articulada a crise na educação e a resposta do homem frente a esse mal-estar, isentando-se de assumir sua responsabilidade frente ao futuro das crianças, marca do que a autora chama de crise da autoridade.
} 
A partir dessas colocações, percebemos que contingências sociais, econômicas, políticas e morais fazem parte do que Caliman (2009) definiu como "fato TDAH". O presente trabalho não pretende se debruçar profundamente sobre esses aspectos, mas a título de compreensão é importante considerar o panorama da construção sócio-médica do TDAH e o discurso hegemônico da ciência que o suporta. Como bem destaca Aranowitz (1998, citado por Caliman, 2010):

Uma patologia só pode ser compreendida através da análise conjunta de sua biologia, das aspirações disciplinares em torno de sua pesquisa, das organizações burocráticas que a financiam e a sustentam, de sua terapêutica, das mudanças em suas práticas investigativas e da forma como o indivíduo e a sociedade a experiencia. (p. 60)

A respeito dos determinantes sociais envolvidos nos problemas de aprendizagem, fazse imprescindível a citação de Maria Helena Souza Patto (2002), renomada autora que inaugurou a discussão sobre o fracasso escolar ao realizar uma vasta pesquisa histórica que verificou como a Psicologia e a Medicina se instauraram no interior do pensamento educacional brasileiro através das explicações sobre a queixa escolar - a Psicologia com a oferta de testes psicológicos e a Medicina com os medicamentos.

\subsection{As avaliações no contexto escolar}

A serviço de que surgiram as avaliações no interior das escolas? Elas respondem exatamente ao que da sociedade? Por que categorizamos as crianças cada vez mais precocemente? Observamos que em nossos dias existe uma multiplicidade de diagnósticos psiquiátricos infantis que não cessa de aumentar. Nomes que nos soam estranhos, como "transtorno das pernas inquietas", "transtorno desafiador-opositivo", vêm numa tentativa afã de localizar uma causa orgânica para toda e qualquer ocorrência do sujeito. O DSM-V, publicado recentemente, já traz em suas páginas, para o público em geral, novos diagnósticosrotuladores, que numa pletora descritiva de sintomas ${ }^{13}$ e sinais ${ }^{14}$ dificilmente deixará "imune" a criança que apresenta em seu comportamento algo de incômodo para o adulto.

\footnotetext{
${ }^{13}$ Para a Medicina, sintoma é um fenômeno subjetivo, referente a alguma alteração orgânica ou funcional (dor, mal-estar etc.), relatado pelo paciente acerca da sua doença e sobre o qual o médico estabelecerá um diagnóstico (Houaiss, 2002).

${ }^{14}$ Sinal, por sua vez, é aquilo que serve de signo. Trata-se de um fenômeno objetivo observado pelo médico no exame do paciente (Houaiss, 2002). Posto isto, entendemos que, em seu trabalho diagnóstico, o médico procura transformar sintomas em sinais, ou seja, subjetividade em objetividade.
} 
Não podemos desconsiderar que a prática da avaliação psicológica nega a determinação e a influência das relações institucionais e sociais sobre o psiquismo. Lembremos que uma avaliação "sela destinos", pois é entendida como definitiva, portadora da verdade sobre a causa de um determinado problema psíquico ou bioquímico (Patto, 1997, 2002).

Consideramos, portanto, que é preciso se ter em conta que a permeabilidade da escola ao discurso médico e psicológico é histórica. Situaremos o surgimento da universalização do ensino no Brasil, para que possamos compreender de que modo as intervenções higienistas nas escolas nas primeiras décadas do século XX já traziam em sua atuação a ideia de uma profilaxia mental, que consistia em agir sobre as crianças da escola e que, de modo similar, vemos ocorrer ainda nos dias de hoje.

Com a extensão do sistema escolar e as leis de escolaridade obrigatória, há um aumento expressivo no contingente de crianças dentro das escolas. Consequentemente, surge uma série de alunos com dificuldades escolares, o que desperta a atenção e interesse de pedagogos, psicólogos e médicos. Nas décadas de 20 e 30 do século passado, houve um enorme esforço da Higiene Mental em dividir os capazes dos não capazes, num processo chamado de higienização social. As precárias condições de saúde da população representavam barreiras de impedimento para o desenvolvimento e crescimento econômico do país. Rapidamente, os médicos higienistas, que ocupavam importantes posições na sociedade, foram convocados para atuar dentro das escolas, com o pressuposto básico de intervir nos corpos, nos costumes e hábitos das crianças e de suas famílias, destituindo a autoridade do pai colonial na educação e determinação do destino dos filhos. Os médicos higienistas, respaldados pelas inúmeras teses das faculdades de Medicina, apregoavam que as famílias não eram capazes de cuidar de seus filhos, o que os autorizava a tomar o seu lugar e a ditar regras. Encontramos em um documento de 1925 escrito pela Liga Brasileira de Higiene Mental sugestões para se educar corretamente uma criança. A visita de enfermeiras e professoras aos lares era prática comum, com o objetivo de aconselhar os pais em suas funções (Costa, 1983).

No início do século XX, Alfred Binet e Théodore Simon estabeleceram uma escala métrica de inteligência e criaram na França um instrumento para medir as faculdades mentais. Depois de se tornarem bastante populares na Europa, os testes chegaram nos EUA e tornaram-se uma das principais ferramentas para avaliar deficiências na aprendizagem. Lewis Terman propôs o teste de Q.I., ainda utilizado hoje em dia, para avaliar as capacidades cognitivas de um sujeito em relação ao seu grupo etário. Frente ao contexto de higienização da infância daquela época, esses testes que pretendem medir a inteligência (e abstrair o 
sujeito) foram rapidamente adotados pelas escolas brasileiras com a ideia de que as dificuldades infantis de aprendizagem poderiam ser medidas e tratadas (Santiago, 2005). Como aponta Santiago (2005), Binet contribuiu com a própria ideia da existência de um déficit, que pode ser medido e que possui uma causalidade orgânica:

O teste de Binet e Simon torna-se o ponto de partida central em torno do qual se elabora uma série de outros testes psicológicos mais específicos destinados a discernir e mensurar, separadamente, cada uma das atividades cognitivas - de percepção, de compreensão, de memória e de abstração. (p. 62)

Essa breve apresentação nos auxilia a verificar que o objetivo final dos médicos higienistas não era observar e intervir unicamente em algo da ordem biológica, na regulamentação daquilo que estaria especificamente relacionado à área da saúde, senão tentar “corrigir” e ordenar muitos problemas sociais e culturais. Daí podemos pensar no caráter ideológico de tais instrumentos, que visavam, por meio de elementos científicos, identificar razões para justificar as desigualdades sociais (Collares \& Moysés, 1997). Atualmente, ainda que a figura do médico não intervenha pessoalmente nas escolas, vemos claramente que o discurso médico está atravessado no imaginário de todos aqueles envolvidos no cenário escolar. Há uma clara tendência em se buscar explicações orgânicas para o não aprender ou para o não se comportar da forma considerada adequada pela escola.

Por muito tempo no Brasil, a Psicologia aplicada à Educação funcionava, segundo revela Pereira (2012), "como uma prática de especialista que detinha, a priori, um saber ortopédico, de normalização e de contenção dos comportamentos desviantes" [grifos do autor] (p. 27). De acordo com essa lógica, as diferenças entre as crianças provinham de questões individuais e não de desigualdades sociais e culturais. Logo, a Psicologia Escolar detinha, como objeto privilegiado de atenção, as dificuldades de aprendizagem, o desenvolvimento fora do esperado e os desvios de comportamento. Os determinantes sociais, as desigualdades de oportunidades, a escola e toda sua gestão não eram questionados.

Com o tempo, o universo escolar passou a agregar em si toda a massa populacional, incluindo os diferentes e os outrora excluídos, localizados à margem da sociedade - fenômeno que ocorreu tardiamente no Brasil após os anos 50 e a Constituição de 1988. Assim, os problemas psicológicos inevitavelmente passaram a ser olhados nos determinantes discursivos que os condicionavam. Assistimos ao gradual interesse em identificar e tratar a criançaproblema e seus impasses, o que resulta, como bem nos lembra Santiago (2005), no aparecimento de diversas clínicas de atendimento médico-psicopedagógico, em atenção à higiene mental das crianças. Tais clínicas apontam para a hegemonia do enfoque 
adaptacionista da Psicologia no seio da escola, servindo a esta última ao oferecer tratamentos reeducativos para as dificuldades escolares. A incorporação de algumas teses psicanalíticas que enfatizam a psicologia do ego e não o inconsciente serviu ainda, nesse cenário, como instrumento de análise, que trouxe a designação dessa criança-problema, fruto de interferências da dimensão afetiva e familiar em seu comportamento e nas dificuldades escolares (Santiago, 2005).

Em sua obra de referência A Produção do Fracasso Escolar, Patto (1990) analisa de que forma o discurso social incide na produção das ditas dificuldades de aprendizagem. Quando a escola apresenta um pré-diagnóstico das dificuldades escolares e possui determinada expectativa em relação aos alunos, qualquer desvio é visto como anormalidade e problema. Essa atitude diagnóstica e preditiva da educação da criança possui graves consequências, pois interfere diretamente sobre a performance do aluno na escola. É possível que a criança vá mal na escola, pois é isso que se espera dela (Jacobson e Rosenthal, 1968, citado por Souza, 2004). Como coloca Souza (2011), são pensamentos que enfatizam aspectos da criança e de sua família em detrimento da análise das causas escolares na produção da queixa escolar.

Podemos pensar que, em situações como esta, aparecer, por exemplo, como hiperativo e desatento é melhor do que aparecer como burro, restando à criança ocupar o lugar de assujeitamento. Sabemos, no entanto, que rotulações diagnósticas suplantam a subjetividade da criança e marcam seu lugar na escola. Nessa perspectiva, há que se considerar, portanto, o efeito das formações discursivas tanto da esfera médica quanto da educacional, pois elas podem acabar aprisionando a criança à dimensão imaginária de ser portadora de um transtorno.

Práticas diagnósticas geradas a partir de tais avaliações psicológicas excluem a realidade escolar na qual a criança está inserida e desconsideram que o sujeito se estrutura na relação com o outro, o que inclui o ambiente escolar. Ao se valorizar um determinado tipo de criança que é tida como modelo e padrão, toda a gama de particularidades do sujeito é discriminada, rechaçada e vista como desviante. Diante disso, resta o encaminhamento aos especialistas, detentores de um suposto saber sobre o mal que acomete a criança e que trará uma saída - na maior parte das vezes a associação de um medicamento com a terapia cognitiva ou reeducação psicopedagógica.

Em seus estudos sobre a biologização da vida, Guarido (2011) critica o modo como são tratadas as manifestações singulares de cada sujeito, através da patologização da aprendizagem. O contexto social é desconsiderado, o psiquismo em constituição também, e a 
medicação ocupa o lugar de salvação, com respostas prontas para qualquer mal que venha a tirar as coisas de uma suposta ordem natural. Quem sofre e por que sofre são questões que ficam relevadas a segundo plano, num movimento que visa esbater qualquer manifestação comportamental dita "desajustada". Perde-se a possibilidade de pensar essa questão do ponto de vista do sofrimento, da singularidade daquilo que a criança está expressando com tais comportamentos, ficando toda a problemática localizada no campo dos transtornos. Como diz a autora, convivemos atualmente com "sofrimentos codificados em termos de uma nomeação própria do discurso médico" (Guarido, 2007, p. 158), o qual se propaga e passa a ordenar a relação do sujeito consigo mesmo.

A colocação do sujeito como portador de 'transtornos de personalidade' dificulta que ele se reconheça com suas determinações inconscientes e sócio-históricas e impede que ele demande, que ele apele ao campo social, que faça laço social, porque está numa posição absolutamente objetificada. (Moysés, 1992, p. 49)

Nos últimos anos, frente aos avanços das neurociências vemos que diante do fracasso escolar predominam ainda mais explicações extraescolares e, cada vez mais, as orgânicas e neurológicas, que camuflam, encobrem e impedem que a sociedade se debruce sobre questões políticas e pedagógicas, sobre o que se passa no interior das escolas para assim poder compreender, dentro do contexto sócio-histórico e cultural de cada época, a razão de certas explicações serem favorecidas.

Como resultado desse entendimento da queixa escolar, vemos que a criança é culpabilizada pelo fracasso e que os demais personagens à sua volta, professores e pais, são desresponsabilizados. Agora, para aliviar a situação de culpa, nem mais a própria criança é sujeito do aprendizado, pois a culpa recai sobre seu cérebro e sobre alguma insuficiência em dar conta da aprendizagem. Temos constatado que esse fortalecimento das psicologias cognitivistas e das neuropsicologias remontam ao início do século XX, com a atuação médica de base positiva regendo a educação e o modo de compreensão das dificuldades escolares. "Buscar de novo a essência da coisa não deixa de ser uma maneira soberba de redução do homem à biologia" (Pereira, 2012, p. 29). Os maus alunos desinteressados de outrora passaram, então, a ser nomeados a partir de novos significantes, tal como o TDAH, desde a introdução do discurso da ciência na escola. O resultado desse tipo de nomeação, de acordo com Santiago (2005), é a "produção exacerbada da patologização e medicalização dos problemas escolares, que não deixa de ocasionar prejuízos muito grandes à trajetória escolar da criança” (p. 18). 
A partir dessa resumida exposição sobre a avaliação das dificuldades escolares no contexto escolar, podemos acompanhar uma trajetória bastante particular: em algumas décadas, passou-se de um entendimento a respeito de tais dificuldades desde um ponto de vista moral - a criança preguiçosa - para uma explicação puramente médica e patológica - o desvio da criança - e, por fim, para um ponto de vista social - o fracasso estaria na inadaptação escolar. O que presenciamos nos dias de hoje é o retorno maciço às explicações médicas.

Sabemos que não são todas as famílias que se sentem aliviadas diante de um diagnóstico psiquiátrico que situe o problema escolar da criança num nível orgânico. Muitos pais preferem não saber, pois isso poderia resultar num mal-estar entre os cônjuges, que tentariam localizar, por exemplo, a herança genética na família do outro e não na sua. Isso revela que sempre estamos num campo onde a singularidade prevalece sobre a tendência de universalizar e objetivar comportamentos, reações e atitudes do sujeito frente ao mal-estar em questão. No entanto, como bem pontua Pereira (2012), não há como negar a existência de um certo "frenesi idólatra em relação à biologia" (p. 29), ao se pensar que a genética e a neurofisiologia trarão as explicações para tudo. A educação escolar insiste em suas exigências de explicações universais para as diferenças individuais. Todavia, nós nos opomos firmemente à ideia de que a psique humana se reduza a giros cerebrais, centros corticais e neurotransmissores, pois uma visão como essa, tão favorecida nos dias de hoje, desconsidera que a subjetividade é efeito das relações sociais, que são tecidas de modo singular por cada sujeito.

Por esse motivo, convocamos a importância ética da Psicanálise, pois, quando falamos de sujeito, temos a exceção como real, estamos falando de sujeito como efeito de um discurso, recusando, assim, quaisquer generalizações. O que nos interessa são as falas, as palavras, a linguagem que marca esse sujeito e não os comportamentos e as sinapses nervosas. A Psicanálise não se deixa enredar pela objetividade científica, mas cuida para "manter suas verdades sempre 'meio-ditas"” (Pereira, 2011, p. 344). 


\section{A INFÂNCIA, A ESCOLA PARTICULAR E SUAS PARTICULARIDADES}

A infância é objeto de inflexões tanto múltiplas quanto históricas, sendo, portanto, produto de realidades "humanas" e infâncias diversas. O fato de tratarmos todas essas infância plurais como $A$ Infância no singular é a prova do caráter tanto universal quanto natural sonhado para a infância moderna que, embora não tão pregnante quanto antes, ainda hoje é referência discursiva para nós. (Lajonquière, 2003, p. 145).

Para que possamos falar da criança tal como é concebida e idealizada nos dias de hoje, faz-se necessário antes contextualizar a emergência do "sentimento de infância" na modernidade como uma construção social, assunto vastamente explorado na obra clássica do historiador francês Philippe Ariès, no livro História Social da Infância e da Família (1981), para então seguir com a concepção de criança presente no discurso pedagógico contemporâneo. Apesar das críticas e questionamentos realizados ao trabalho deste autor, apontando a carência metodológica de suas teses fundadas em fontes iconográficas, consideramos que Ariès possui o seu mérito por ter questionado o conceito de criança como um objeto natural dado. Ao longo da história, verificamos que a infância apresenta características determinadas por fatores socioculturais específicos de cada época e de cada sociedade. Excederia o objetivo deste trabalho apresentar e analisar as transformações do conceito de infância ao longo da história. No entanto, faremos algumas articulações que consideramos importantes para a discussão.

Versaremos a seguir sobre a criança que a Psicanálise freudiana descortina e o modo como esse novo saber demarca um divisor de águas, rompendo com as representações e significações até então mantidas no imaginário social e levando em consideração o que a Psicanálise tem a dizer sobre a criança como sujeito em constituição.

Abordaremos brevemente o histórico do surgimento da escola no Brasil, as repercussões advindas do aumento do contingente de crianças na escola e o fracasso escolar daí decorrente e constituído como um grande obstáculo ao tão propalado desenvolvimento econômico do país, questão apresentada no capítulo anterior quando discutimos a questão das avaliações psicológicas. Por fim, nós nos deteremos na caracterização da escola particular de 
“elite", cujos professores são alvo do presente trabalho. Buscaremos destacar alguns aspectos peculiares da classe dominante que frequenta essas escolas em seu processo de escolarização.

\subsection{Infância como uma construção discursiva histórica}

É provável que a apresentação que se segue seja familiar àquele que esteja envolvido com o campo educativo. Contudo, é relevante para os propósitos deste trabalho contextualizar a historicidade da ideia de infância, entendida como uma invenção societária. O conceito de criança e de infância, com todas as representações conhecidas atualmente, é uma concepção bastante recente, cuja origem está localizada no século XII e se consolida no fim do século XVII e começo do século XVIII. A noção de infância como uma "fase da vida" pode ser pensada como resultado de um processo de incursões ocorridas ao longo da história, marcado por transformações que propiciaram mudanças no que tange ao tratamento despendido à criança.

Logo, refletir sobre a criança implica em pensar a sociedade, a cultura, as diferentes formas de estruturação familiar e as relações de poder estabelecidas historicamente. A concepção de infância só pode ser entendida por meio de representações que foram e são estabelecidas no seio das relações entre o adulto e a criança no decorrer do tempo (Freitas \& Kuhlmann, 2002). Não é o objetivo deste trabalho pontuar exaustivamente as inúmeras transformações históricas, sociológicas e econômicas da sociedade medieval, que culminaram no advento da modernidade e, consequentemente, da infância tal como é tomada atualmente. Faremos, porém, uma breve incursão no tema, para situar o leitor a respeito do modo como a infância passou do anonimato histórico "à verdade discursiva de nossos tempos", à imagem da "criança-esperança" (Pereira, 2011, p. 338).

A etimologia da palavra "infância" vem do latim infans ou in fari, que significa "aquele que não fala", isto é, aquele que se distingue do adulto pela não apropriação da fala. O termo, que antigamente remetia aos que não podiam se valer do uso da palavra para dar testemunho nos tribunais, exprime nada mais do que a condição de estar, de fato, privado da palavra, dependente e à mercê das ordens dos outros (Lajonquière, 1999; Pereira, 2011). A noção de infância envolve um período de tempo específico, o início da vida, durante o qual o ser humano está privado de algo: da fala, da maturidade ou daquilo que pertence ao mundo adulto. 
Philippe Ariès (1981) deteve-se longamente na análise da infância na sociedade ocidental europeia, especialmente a francesa, na busca por decifrar os lugares assumidos pela criança e pela família ao longo do tempo. Segundo o autor, a chamada "descoberta da infância" teve início no século XIII, estendendo-se até o século XVI, quando começou a existir uma maior valorização da infância, como se observa pelas pinturas renascentistas, pelo surgimento da família nuclear moderna e pela abrangência dos sistemas escolares. Até o advento da modernidade, segundo o autor, não havia no imaginário social o lugar simbólico de destaque da infância tal como a consideramos atualmente. Digno de nota é que Ariès (1981), ao comentar a inexistência do sentimento de infância, não queria com isso dizer que as crianças eram negligenciadas ou desprezadas.

O sentimento de infância não significa o mesmo que afeição pelas crianças: corresponde à consciência da particularidade infantil, essa particularidade que distingue essencialmente a criança do adulto, mesmo jovem. Essa consciência não existia. (Ariès, 1981, p. 156)

Na sociedade medieval, tão logo terminasse o período de maior dependência da mãe ou da ama de leite, as crianças participavam das mesmas atividades e ambientes que os adultos, sem experimentar um período de passagem - inexistia a adolescência. As crianças eram educadas em tenra idade por meio da chamada impregnação cultural, e a transmissão se dava de forma pública pela convivência com os adultos (Ariès, 1981). O cuidado específico, o tratamento endereçado exclusivamente às crianças e a indicação da idade não faziam parte da cultura europeia medieval. Dos adultos que lidavam com as crianças, não era exigida nenhuma preparação, e contava-se com as chamadas criadeiras, amas de leite ou mães mercenárias (Ariès, 1981). Até mesmo o costume de dar um nome exclusivo a cada filho só veio a aparecer por volta do século XVII (Postman, 1999).

Em todas as fontes, descobre-se que na Idade Média a infância terminava aos sete anos. Por que sete? Porque é nesta idade que as crianças dominam a palavra. . . . Podem conhecer todos os segredos da língua, que são os únicos segredos que precisam conhecer. (Postman, 1999, p. 28)

Havia uma convivência precoce da criança com a vida coletiva dos adultos, na qual se dava a aprendizagem a respeito da cultura e do mundo ao redor. O chamado "sentimento de infância", que distinguiria radicalmente a criança do adulto, segundo Ariès (1981), não existia naquela época.

A duração da infância era reduzida a um período mais frágil, enquanto o filhote do homem ainda não conseguia bastar-se; a criança, então, mal adquiria algum desembaraço físico, era logo misturada aos adultos, e partilhava de seus trabalhos e jogos. De criancinha pequena, ela se transformava imediatamente em homem; mas sem passar pelas etapas da juventude, que 
talvez fossem praticadas antes da Idade Média e que se tornaram aspectos essenciais das sociedades desenvolvidas de hoje. (Ariès, 1981, p. 10)

$\mathrm{Na}$ antiga cultura grega e romana, conforme Postman (1999), ainda era encontrada certa atenção a questões de proteção e educação das crianças, ligando a infância à escolarização, como, por exemplo, a importância de se exercitar corporalmente e aprender a ler e a escrever, o que se perde na época medieval.

Até mesmo na arte da Idade Média podemos comprovar como não havia preocupação em representar a infância ou a criança, que era pintada como um adulto em miniatura, sem nenhuma diferenciação de traços ou de expressão. Até o século XII não havia, portanto, uma representação que demonstrasse uma preocupação com a infância tal como a concebemos na modernidade. Ela era entendida como uma época de transição, que passava rapidamente e que seria esquecida em seguida. Daí a falta de interesse por essa fase da vida.

Até por volta do século XII, a arte medieval desconhecia a infância ou não tentava representála. É difícil crer que essa ausência se devesse à incompetência ou à falta de habilidade. É mais provável que não houvesse lugar para a infância nesse mundo. (Ariès, 1981, p. 50)

Um fator que corroborava para que as crianças não fossem alvo de tamanha devoção até o século XII dizia respeito às precárias condições gerais de higiene e saúde, que tornavam o índice de mortalidade infantil muito alto. A esse respeito, apontam Ariès e Heywood:

Contudo, um sentimento superficial da criança - a que chamei de "paparicação" - era reservado à criancinha em seus primeiros anos de vida, enquanto ela ainda era uma coisinha engraçadinha. As pessoas se divertiam com a criança pequena como um animalzinho, um macaquinho impudico. Se ela morresse então, como muitas vezes acontecia, alguns podiam ficar desolados, mas a regra geral era não fazer muito caso, pois outra criança logo a substituiria. A criança não chegava a sair de uma espécie de anonimato. (Ariès, 1981, p. 10)

Pode-se apresentar um argumento contundente para demonstrar que a suposta indiferença com relação à infância nos períodos medieval e moderno resultou em uma postura insensível com relação à criação de filhos. Os bebês abaixo de dois anos, em particular, sofriam de descaso assustador, com os pais considerando pouco aconselhável investir muito tempo ou esforço em um "pobre animal suspirante", que tinha tantas probabilidades de morrer com pouca idade. (Heywood, 2004, p. 87)

No século XIII, em vez de se procurar entender e aceitar as diferenças e semelhanças das crianças, a originalidade de seu pensamento, pensava-se nelas como páginas em branco, as chamadas tábulas rasas, a serem preparadas para a vida adulta. A mudança de paradigma no que se refere ao conceito de infância está diretamente ligada com o fato de que as crianças eram consideradas adultos imperfeitos. Sendo assim, essa etapa da vida provavelmente seria 
de pouco interesse. "Somente em épocas comparativamente recentes veio a surgir um sentimento de que as crianças são especiais e diferentes e, portanto, dignas de ser estudadas por si sós" (Heywood, 2004, p. 10).

De acordo com a análise de Postman (1999), um comunicólogo americano, a invenção da imprensa em meados do século XV modificou radicalmente a relação dos adultos com seus saberes e teve grande impacto na criação da ideia moderna de infância e de educação. É notável o fato de que a necessidade de acesso ao universo letrado, processo visto como resultado de uma adequação natural da criança, foi responsável pela delimitação do conceito de infância da modernidade.

Nos séculos XVI e XVII, a noção de infância foi então se consolidando, segundo Postman (1999), como um efeito da mudança social provocada pela invenção e aperfeiçoamento da imprensa - e a consequente separação entre aqueles que sabiam ler e os que não sabiam - e em decorrência de uma moralização da sociedade relacionada ao fenômeno burguês. Houve neste período uma mudança no "sentimento de infância", como se evidenciou no préstimo da figura da criança pela religião, na chamada "paparicação" dos adultos e na concepção de "inocência infantil" (Postman, 1999, pp. 68 e 136). A partir de então, foi reconhecida a importância da educação destinada às crianças e surgiu uma preocupação com o desenvolvimento moral e mental delas.

As reformas religiosas e a constituição do Estado Moderno, a partir do século XVIII, também contribuíram com a geração do sentimento de infância. Anotemos mais um trecho de Ariès (1981), referente à vinculação do ambiente escolar e o surgimento desse sentimento: "Essa separação - e essa chamada à razão - das crianças deve ser interpretada como uma das faces do grande movimento de moralização dos homens promovido pelos reformadores católicos ou protestantes ligados à Igreja, às leis ou ao Estado" (p. 11). A reforma luterana, de acordo com Cauvilla (1999), teve como uma de suas principais características a criação de escolas, enquanto que a Contra Reforma católica no Brasil também fez do ensino uma de suas principais ações em defesa da Igreja Católica.

A partir do momento em que a criança passou a ser concebida como um ser que necessita de preparo antes que venha a participar do mundo adulto, foi que a escola adquiriu importância fundamental na definição da criança e que esta passou a ser pensada como criança escolar. O espírito republicano impôs uma crescente necessidade de tornar a criança letrada e preparada.

A emergência de uma concepção de infância como idade privilegiada foi favorecida, portanto, por uma revolução educacional, que a partir do século XVI passou a separar a 
criança da convivência direta com o adulto, por ela ser considerada ainda imatura e delegando-a aos cuidados de profissionais especializados, além de conferir à família a responsabilidade pela observação da vida educacional da criança (Bauman, 1998).

Fatos ao longo do século XVIII e posteriores, tais como a diminuição da mortalidade infantil, a descoberta da tipografia, da pedagogia, da pediatria e da psiquiatria e, posteriormente, da psicologia com suas especialidades, fizeram com que o sentimento e o tratamento para com a criança também se modificassem (Marino \& Baptista, 2007). Mannoni (1977) considera pertinente falar em "descoberta da criança" como o grande acontecimento dos tempos modernos, provocando o aparecimento da instituição educacional, entre outros efeitos.

Sublinhamos aqui a preocupação com a mortalidade infantil como um dos aspectos presentes no investimento que passou a ser feito na criança, com o objetivo de barrar o alto índice de mortes que caracterizava o Antigo Regime. Concomitante a isso, temos o surgimento da demografia, uma nova disciplina que viria a contabilizar os habitantes de um país para dimensionar o potencial produtivo do Estado e engrossar a força militar (Marino \& Baptista, 2007). Os asilos mantidos para as crianças abandonadas passaram a ser vistos como desperdício, pois essas crianças em sua grande maioria (90\%) morriam antes de se tornarem produtivas.

A passagem para a modernidade configura-se, assim, como um momento de formalização da demanda social em termos da educação, já que as crianças deveriam ser protegidas, amparadas e educadas. Passa-se a considerar que a criança não é um ser maduro para a vida e, por essa razão, ela se torna “objeto de estratégias educacionais" (Petitat, 1994, p. 90). É em decorrência de uma questão econômica, da constituição da sociedade capitalista, da organização do trabalho industrial e da urbanização que o discurso médico-higienista teve, assim, forte repercussão social, vindo a incidir nas escolas. Os médicos passaram a pregar a necessidade de mudanças por meio desse ideal higiênico, que ditava regras e normas para o comportamento e aperfeiçoamento do "futuro homem da sociedade". Havia uma questão fundamentalmente moral por detrás desses ideais defendidos pela medicina do século XIX (Costa, 1989).

O início do século XIX foi marcado por mudanças importantes na concepção de homem e de mundo, que influenciaram diretamente na noção e na representação da criança como "indivíduo". As transformações no âmbito do conhecimento, do uso da razão e da valorização da consciência foram fundamentais para essa nova forma de tratamento (Smolka, 2002). Frente à crescente produção de conhecimento daquela época, a infância moderna 
passou a representar e designar um período permeado pelos ideais de futuro e esperança, ou seja, "o ponto de fuga no horizonte dos sonhos adultos" (Lajonquière, 2003, p. 149), onde encontramos o desejo e o narcisismo desses adultos, a respeito dos quais nos fala a Psicanálise - tema discutido no próximo item - e que transformam a infância numa depositária imaginária deste sonho.

A ideia de progresso e de evolução levou, assim, a uma sistematização nos conhecimentos sobre a criança, caracterizados sobretudo pelo aperfeiçoamento de suas aquisições e habilidades, tendo em mente uma criança tomada como modelo de normalidade. Nesse sentido, há uma expectativa social sobre a qual a criança é convocada a responder desde muito cedo, incluindo o que pais, professores e profissionais de saúde esperam em termos de ritmo de desenvolvimento. Num contexto onde a infância passou a ser concebida como uma fase da vida, a criança tornou-se objeto privilegiado de estudo e de "cuidados", pois tudo começa a ser pensado e realizado visando o seu bem.

Atualmente, com o aumento vertiginoso da venda de medicamentos psicotrópicos para crianças, o que se evidencia é que a criança se tornou objeto privilegiado do discurso médicocientífico que, conforme salientamos anteriormente, passou a buscar o silenciamento de comportamentos tratados como transtornos. Frente a esse cenário, a administração de Ritalina para acalmar e ajudar o aluno a prestar atenção e ter sucesso escolar faria sentido e seria não só indicada como amplamente aconselhada para um número cada vez maior de crianças que fogem ao comportamento esperado dentro da escola. Seria esta uma marca da concepção de criança na modernidade, assunto sobre o qual nos deteremos mais adiante.

Em suma, a criança, segundo os ideais de "possibilidade" e "futuro" que permearam a noção de infância na modernidade, passou a corresponder à expectativa dos adultos dessa conjunção representativa. A tomada da criança pelo discurso conferiu-lhe visibilidade, porém, fixou-a como aposta do futuro da civilização. Como afirma Priszkulnik (2000), a criança passou a ter o dever de contemplar a demanda de ser comportada, brilhante e capaz. Parafraseando Hannah Arendt em referência ao registro moderno dos acontecimentos passados, a infância foi o "precipitado da imortalidade terrena à qual aspirava a Idade Moderna" (Lajonquière, 2003, p. 149). 
2.2 Da modernidade à contemporaneidade: os impasses subjacentes ao lugar reservado à criança escolar

Partindo do que foi exposto até o momento, podemos entender que as mudanças de atitude em relação às crianças ao longo da história marcam as diferentes representações de infância a partir de discursos e posicionamentos sociais a respeito dessa etapa da vida. Conforme discutido acima, a relação que hoje nos parece evidente entre crianças e escolas, assim como qualquer outra relação social, não é natural. A partir do momento em que as experiências da infância ganharam relevo, foram criadas políticas que visavam promover e ampliar as condições necessárias para o exercício da cidadania das crianças, que, por sua vez, passaram a ocupar lugar de destaque na sociedade. A afirmação da educação das crianças como um valor e um direito é, assim, fruto de um longo processo histórico repleto de idas e vindas.

As famílias passaram a se mobilizar para a plena instalação da criança na sociedade a partir das mudanças destacadas até aqui e, nos dias atuais, o valor dos filhos para a sociedade é medido, prioritariamente, pelo seu valor escolar, o que faz com que os processos de escolarização adquiram um papel de destaque no seio das famílias. Nesse contexto, o sucesso escolar dos filhos refletiria o sucesso dos pais, ao passo que o fracasso refletiria a "incompetência" da família.

Tudo se passa como se o êxito do filho constituísse uma espécie de símbolo do êxito pessoal dos pais, do bem fundado de seus valores e de sua concepção de educação; como se esse êxito se tornasse para os pais um critério fundamental de sua autoestima. (Godard, citado por Nogueira, 2004, p. 119)

A instituição escolar, como uma invenção da modernidade, possui um enorme papel subjetivante, conforme nos aponta Lajonquière. A escola despontou como um lugar público, não familiar, onde as crianças eram interpeladas a responderem como se fossem os adultos que ainda não eram. Nas palavras do autor, "a chamada escola republicana foi a figuração discursiva mais acabada da infância dita moderna" (Lajonquière, 2006, p. 11), já que precipitou um dispositivo arbitrário, que forjou o tempo psíquico de espera por uma recompensa sonhada. Por ter incorporado em si a tensão narcisismo/desejo embutida na infância - tópico que será abordado mais adiante -, todos intuíram que a escola detinha "a 
chave de acesso à infância, e esta, por sua vez, era a chave que dava acesso a um mundo Outro aqui mesmo na terra" (Lajonquière, 2003, p. 150).

O teatro escolar gira em torno de uma paradoxal demanda endereçada às crianças. Ele implica, por um lado, uma dialética entre o lado criança e "sua psicologia infantil", recalcados à intimidade privada do lar, e o lado aluno que frequenta a escola e, portanto, que passa a ficar sob o olhar do público - isto é, sob os olhos da República. (Lajonquière, 2003, p. 150)

O destaque atribuído e dispensado à educação escolar no Brasil pode ser encontrado na Lei de Diretrizes e Bases da Educação Nacional n. 9394/96, que afirma que "o dever do Estado com educação escolar pública está efetivado mediante a garantia de (...) atendimento gratuito em creches e pré-escolas às crianças de zero a seis anos de idade". A criação do Conselho da Criança e do Adolescente, no ano 1990, que explicitou melhor cada um dos direitos da criança e do adolescente, bem como os princípios que devem nortear as políticas de atendimento, também representa um marco importante, com a criação do Estatuto da Criança e do Adolescente (ECA) e dos Conselhos Tutelares. Na visão de muitos autores, a criação do ECA é vista como um marco no que diz respeito ao reconhecimento e valorização da infância por parte das políticas públicas, uma vez que a partir daí as crianças passaram a ser "sujeito de direitos" em sua peculiar condição de "pessoas em desenvolvimento".

A família nuclear e a escola tiveram assim um papel fundamental na criação de um lugar simbólico para a infância na modernidade, já que, como afirma Kupfer (2007), "a criança moderna é uma criança indissoluvelmente ligada ao escolar, que lhe atribui o lugar social, a inserção social, é o que a constitui, o que lhe dá identidade" (p. 36). Tal criação, apesar de ter produzido um lugar simbólico para a infância, possibilitando ao adulto endereçar à criança um discurso que limitasse lugares e contornasse possibilidades discursivas, acabou também por gerar uma série de necessidades imaginárias de conhecer a criança sob todos os aspectos, na intenção de classificá-la, avaliá-la, medi-la, impedindo, talvez, a possibilidade do adulto de se reconhecer nela, tamanho o mosaico de saberes científicos ali depositados.

Segundo Pereira (2011), a Pedagogia, a Psiquiatria e a Psicologia tornaram-se alguns dos dispositivos modernos mais significativos na busca de revelar saberes sobre a criança, encarnando um apelo sistemático à objetividade científica por meio de métodos de ensino ditos apropriados e procedimentos diagnósticos. A esse respeito o autor afirma:

A atualidade da criança sustenta-se numa evanescência que a mantém exposta a uma desmedida operação de aderência imaginária aos ideais estabelecidos e vigiados pelos observadores da perícia psicopatológica ou pelos observadores das condutas psicopedagógicas. (Pereira, 2011, p. 341) 
Uma infância que requer tratamento e solicita que "especialistas" lhe revelem a sua verdade seguramente não é uma infância qualquer. Assim, a noção de infância na modernidade se articula dentro de uma política de verdades, amparada pela autoridade do saber de seus porta-vozes. A esse respeito, Vorcaro (2011) sustenta que:

A infância tornou-se objeto de disputa de poderes, configurada como uma zona limítrofe de confronto entre o público e o privado, gerando novos saberes e modalidades de controle. $\mathrm{O}$ cuidado com as crianças ultrapassou família e escola, sendo abarcado pelo discurso médico sobre a infância. (p. 220)

Partindo-se dessa concepção moderna de infância, até a atualidade foi percorrido um caminho intenso, que situou a criança em uma posição nunca antes ocupada. Conforme o levantamento bibliográfico realizado, verifica-se que a criança como centro do processo educativo é uma concepção relativamente recente, tributária do espírito da Escola Nova, que, por sua vez, foi diretamente influenciado por teorias psicológicas e pela tese da adequação natural. Nesse ponto, o estabelecimento de metas escolares passou a se subordinar às teorias de desenvolvimento infantil e a uma atitude de respeito à autonomia do aluno.

Desde Rousseau, que em sua obra fundamental, Emílio, lançou o início da preocupação em estudar como conduzir a criança por meio da educação, conhecer a criança de modo a adequar a ação educativa passou a animar o espírito pedagógico. "Calibrar a atividade que lhe será proposta segundo o seu estágio de desenvolvimento" representa o modo de busca desta adequação, comenta Voltolini (2011b , p. 41).

A maneira como a infância é vista atualmente, e que evidencia a pregnância das ditas capacidades psicológicas naturais, pode ser encontrada nos Parâmetros Curriculares Nacionais (PCN), no qual localizamos expressões como "capacidade a ser desenvolvida", "intervenções pedagógicas adequadas" ou "intervenções ajustadas às capacidades cognitivas dos alunos" (Lajonquière, 1999, pp. 56-65). Opera, portanto, no ideário pedagógico uma lógica de uma relação direta e indissolúvel entre disciplina, aprendizagem e maturação psicológica, segundo a qual os problemas, tanto de aprendizagem quanto de indisciplina, estariam relacionados apenas a uma falta de ajuste frente a um desenvolvimento que se supõe dado. No cotidiano escolar, a "caça ao detalhe de indícios de perturbações cognitivas ou comportamentais" adquire, assim, justificação científico-psicológica (Lajonquière, 1999, p. 57). Esta lógica natural do aprender poderia, por sua vez, ser atrapalhada por algum transtorno orgânico que viria a acometer o cérebro da criança e assim, mais uma vez, causas externas estariam na base explicativa dos impasses escolares. 
Em nossos dias, como afirma Lajonquière (2003), vê-se um “apagamento da distinção entre o escolar e o familiar, na esteira do esvaziamento da diferença entre o público e privado" (p. 151), resultante, por um lado, do imperialismo das escolas particulares - onde o cliente é quem manda e sempre tem razão - e, por outro, dos psicologismos da vida cotidiana - em que as manifestações infantis são, muitas vezes, enquadradas em manuais psicológicos e psiquiátricos, tendo como reflexo uma boa quantidade de teses pedagógicas que prescrevem uma norma natural de desenvolvimento psicológico. A criança é entregue e "lida" em sua infantilidade por um séquito de profissionais ligados ao campo psi, que pretendem e alegam tudo ver e tudo saber.

Como denuncia Lajonquière (1999), se a educação hoje se converte a priori em um fenômeno de difícil acontecimento, tal coisa se deve ao império do ideário (psico)pedagógico contemporâneo, que revela um processo de psicologização das experiências educativas. Ou seja, haveria certos parâmetros esperados de comportamento prescritos pelas teses e que deveriam ser alcançados, caso contrário, os especialistas interviriam para suprir as lacunas das crianças e alcançar uma normatização. Numa busca inadvertida de cumprir essa tarefa sabidamente inexequível, cria-se uma espécie de mito moderno da infância, em que a criança aparece como "A" criança idealizada e abstrata, à sombra da qual "todas as outras, de "carne e osso', passaram a estar em risco de serem desrespeitadas, seja no interior das famílias, da escola ou da sociedade" (Lajonquière, 2010, p. 21).

As crianças que antes eram chamadas, por exemplo, de tímidas, preguiçosas ou maus alunos são agora consideradas, independentemente do cenário, de imaturas, hiperativas ou portadoras de algum déficit ou transtorno. Operam no cotidiano de muitas escolas raciocínios ditos viciosos, marcados por esse discurso que impera na atualidade e que leva profissionais da educação a, por exemplo, encaminhar à psicopedagoga ou ao neuropsicólogo uma criança que conversa muito em sala de aula ou é muito agitada, pois subentende-se que essa conduta seja indício de algum desajuste ou problema que venha a aparecer no futuro. Cabe ressaltar que quaisquer que sejam as informações recebidas dos chamados "especialistas", elas sempre serão insuficientes, pois nada revelam sobre a singularidade subjetiva do agir de uma criança e tampouco sobre o que fazer de concreto em sala de aula. Os laudos trariam, assim, apenas um sossego moral para aqueles que o recebem em mãos e que podem, dessa forma, continuar fazendo o que vinham fazendo até então.

Essa multiplicação de conhecimentos sobre a criança, marca da contemporaneidade, evidencia o quanto ela continua sendo inapreensível para os adultos, impossível de ser controlada e previsível em seus desdobramentos, insistindo em não se deixar apreender, 
inclusive por meio dos chamados fracassos escolares, que insistem em se multiplicar. $\mathrm{O}$ acúmulo de conhecimentos nos faz evocar a anedota da centopeia, a quem foi perguntado como sabia com que perna dar o próximo passo e que, segundo consta, depois disso nunca mais andou. Com isso, queremos dizer que a operacionalidade do processo educativo fica comprometida e carrega consigo a angústia de que tanto conhecimento não traz, no fundo, nenhum saber (Voltolini, 2011b).

Nesse sentido, Lajonquière (1999) nos alerta sobre os perigos do inflacionamento psicopedagógico, visto como um operador de leitura da pedagogia moderna, pois "quanto mais inflacionada está a dimensão psicopedagógica, mais fica comprometida a educativa" (p. 25). Os impasses educativos atuais, manifestos em diversas facetas e investigados por ilustres autores, incluindo o fracasso escolar, a violência e a evasão, atestam que ocorre algo com o lugar construído para a infância moderna. Nesse contexto, um dos reflexos do fracasso que se observa atualmente é o grande encaminhamento, partindo de muitas escolas, de crianças para psicopedagogos e/ou neuropsicólogos e o aumento do número de diagnósticos psiquiátricos e de prescrições de psicotrópicos a crianças.

À época em que sua tese de livre-docência foi escrita, Lajonquière (1999) esboçava uma preocupação e interesse especiais pela importância que passou a ser concedida pela Pedagogia ao campo e ao saber da (Psico)pedagogia e às consequências disso, como a renúncia ao ato educativo e o esgotamento do tempo da infância. No entanto, hoje, passados quinze anos, podemos incluir uma preocupação social talvez ainda maior, que diz respeito à psiquiatrização do cotidiano escolar e à medicalização da infância.

Se até aqui a Pedagogia moderna nutria-se da ilusão de um desenvolvimento natural das crianças graças a uma estimulação ambiental correta, efeito do imperialismo dos saberes psicológicos, em nossa época o discurso hegemônico da ciência domina o cenário com explicações organicistas para as ocorrências e vicissitudes de uma educação escolar. No capítulo seguinte, iremos nos debruçar sobre essa questão, embasados numa leitura psicanalítica, a fim de compreender o significado do aumento vertiginoso do diagnóstico de TDAH e de sua ampla aceitação social.

Retomando, todas essas mudanças sobre a concepção de criança ocorreram no âmbito familiar por meio da importância do filho e a transformação do lugar ocupado por ele na família contemporânea. Essa nova configuração leva a uma nova relação entre família e instituição escolar, baseada no surgimento de um olhar diferente sobre a criança e o lugar que ela passa a ocupar no nosso imaginário. Esse novo olhar surge a partir do momento em que a criança passa a ser desejada por seus pais, tendo maior valor afetivo e 
não apenas representando mais uma perspectiva de ganho para os pais por meio de futura força de trabalho.

Esse dispositivo discursivo parental está sustentado, em grande parte, pelas instâncias psíquicas do narcisismo e do ideal de eu, as quais a Psicanálise vem nos mostrar e sobre as quais discorreremos neste trabalho para fins da análise dos achados da pesquisa de campo. Avancemos, portanto, primeiramente com a concepção psicanalítica de criança lançada na virada do século XIX para o XX ao trazer um outro dispositivo discursivo sobre o infantil, para então pensar sobre esse investimento parental, chamado narcísico, sobre as crianças e suas consequências na época atual, uma vez que ele está atrelado ao discurso hegemônico da ciência e à permeabilidade da escola a ele.

2.3 A infância, o infantil e a Psicanálise

No fim do século XIX, Freud aparece para marcar radicalmente o discurso sobre a infância circulante até então e recoloca o debate sobre os sentimentos, as representações e o surgimento da infância num contexto para além da clássica tensão entre a dualidade biologismo e culturalismo.

Lajonquière (2003) diz: "Tanto num quanto no outro, uma vez que a determinação jamais acontece no sentido forte do termo, não há lugar para se pensar as vicissitudes próprias da instituição de uma subjetividade" (p. 141). Com essa colocação, ele pretende demonstrar que nunca podemos falar de uma determinação social ou biológica, pois se trata acima de tudo da constituição de uma subjetividade engendrada e instituída pela "atualização de determinações prévias à emergência propriamente dita" (Lajonquière, 2003, p. 141).

Com a publicação de $A$ Interpretação dos Sonhos, em 1899, seu livro mais influente, e a seguir com o texto Três Ensaios sobre a Teoria da Sexualidade (1905), Freud vem a subverter uma série de pressupostos sobre o sujeito, tidos até então como verdadeiros. Além de questionar a noção do homem como ser essencialmente racional e detentor de uma consciência absoluta, apresentando o conceito de inconsciente, ele discutiu ainda a moral sexual da época ao apresentar uma ideia revolucionária da sexualidade como inerente e central na formação do ser humano. Para além de como a questão sexual era entendida até então, atrelada e restrita à genitalidade, Freud tratou de apresentar um novo entendimento sobre o sexual, relacionando-o ao desejo e àquilo que é necessário para que um ser se torne 
sujeito humano e que diz respeito a um campo de significações que se sobrepõe ao biológico e que vem marcar a criança.

O que Freud descobriu, em suma, é que o que faz a criança tornar-se alguém é que ela deseja. E mais: deseja porque alguém a desejou e a antecipou como desejante, introduzindo-a nesse campo pulsional. (Bernardino, 2006, p. 20)

A grande subversão da Psicanálise referente ao entendimento de infância foi justamente revelar, a partir da análise do discurso dos adultos, a sexualidade infantil presente já nos bebês (Bernardino, 2006). A ideia que se tinha sobre as crianças como seres puros, inocentes, frágeis, ingênuos e assexuados - e que vemos ainda hoje permear o imaginário das representações sociais sobre a criança - mostrou-se falaciosa e causou espanto na conservadora sociedade do século XIX.

A infância era encarada como inocente e isenta dos intensos desejos do sexo, e não se pensava que a luta contra o demônio da sensualidade começasse antes da agitada idade da puberdade; tais atividades sexuais ocasionais, conforme tinha sido impossível desprezar nas crianças, eram postas de lado como indícios de degenerescência ou de depravação prematura, ou como curiosa aberração da natureza; poucos dos achados da Psicanálise tiveram tanta contestação universal ou despertaram tamanha explosão de indignação como a afirmativa de que a função sexual se inicia no começo da vida e revela sua presença por importantes indícios na infância. (Freud, 1908b/1996, p. 46-47)

Desde as primeiras publicações psicanalíticas, Freud insistiu na importância da infância na etiologia sexual das neuroses. Inicialmente, serviu-se do modelo da teoria do trauma da sedução precoce, à qual todo sujeito neurótico teria sido submetido no tempo de sua infância, para justificar a causa das neuroses. Em 1897, ele abandonou a teoria da sedução sexual numa carta dirigida a Fliess: "E agora quero confiar-lhe, de imediato, o grande segredo que foi despontando lentamente em mim nestes últimos meses. Não acredito mais em minha neurótica" (Freud, 1897/1996, p. 350).

Embora tenha abandonado essa teoria, Freud manteve a infância dos pacientes na origem dos conflitos neuróticos, ainda que de um modo distinto, articulando o sexual e o infantil. É fato que nessa época o autor não dispunha ainda do conceito de inconsciente e que a sexualidade infantil era apenas uma suspeita. Entretanto, esse momento representa um marco fundamental do pensamento freudiano, a saber: a consideração da realidade psíquica para falar da prevalência da fantasia - já que a sedução não era real -, o que iria se desdobrar naquilo que hoje conhecemos como complexo de Édipo (Garcia-Roza, 2005). 
Cremos ser importante sublinhar que Freud, apesar de abandonar a teoria da sedução, não deixou de assinalar os cuidados maternos como fonte de excitações sexuais e de uma sedução à qual a criança permanece sujeita durante toda a infância.

A relação de uma criança com quem quer que seja responsável por seu cuidado proporcionalhe uma fonte infindável de excitação sexual e de satisfação de suas zonas erógenas. Isso é especialmente verdadeiro, já que a pessoa que cuida dela, que afinal de contas, em geral é sua mãe, olha-a com sentimentos que se originam de sua própria vida sexual: ela a acaricia, beijaa, embala-a e muito claramente a trata como um substitutivo de um objeto sexual completo. (Freud, 1905/1996, pp. 229-230)

O estado original da sexualidade infantil, anterior ainda ao narcisismo, é chamado de autoerotismo. Neste, a pulsão ${ }^{15}$ sexual encontra o seu "apoio" na pulsão de autoconservação, mantendo uma relação com as funções ligadas à conservação da vida. $\mathrm{Na}$ amamentação protótipo da experiência de satisfação -, inicialmente a ingestão do leite é que satisfaz um estado de necessidade de nutrição e por isso o bebê suga o seio. Porém, ao mesmo tempo em que o faz, o lactente tem seus lábios e língua excitados pelo peito materno, o que produz uma satisfação que vai além da saciedade alimentar, ainda que encontre nesta o seu apoio (GarciaRoza, 2005).

Temos, então, um primeiro momento no qual o objeto específico está ligado à autoconservação. A pulsão somente emerge quando, por apoio nessa função, produz-se o prazer de sugar o seio desvinculado do prazer pela satisfação de se alimentar. Portanto, quando o objetivo e o objeto ganham autonomia a despeito da alimentação é que a criança passa, por exemplo, a chupar o dedo, sendo esta a primeira forma de manifestação da pulsão e o protótipo da sexualidade oral propriamente dita (Garcia-Roza, 2005; Mezan, 2008).

Nosso estudo do ato de sugar o dedo ou sugar sensual já nos forneceu as três características essenciais de uma manifestação sexual infantil. Em sua origem ela se apoia em uma das funções somáticas vitais; ainda não se tem objeto sexual e é, assim, autoerótica; e seu objetivo sexual é dominado por uma zona erógena. . . . É claro que o comportamento de uma criança ao sugar o dedo é determinado pela busca de um prazer já experimentado e que neste momento é recordado. . . . Foi a primeira e mais vital atividade da criança, a sucção do seio materno, ou de seus substitutos, que a familiarizou com este prazer. (Freud, 1905/1996, pp. 186-187)

\footnotetext{
${ }^{15} \mathrm{O}$ conceito de pulsão (Trieb) em Freud possui um significado distinto do termo Instinkt, o que se constitui muitas vezes num entrave para o leitor leigo, que não está familiarizado com a Psicanálise. Freud tratou de acentuar a diferença fundamental entre ambos os termos. Enquanto o instinto designa um comportamento fixado hereditariamente, com um objeto fixo e pré-determinado; a pulsão por sua vez varia de objeto e de objetivo (Garcia-Roza, 2005). "Uma pulsão nos aparecerá como sendo um conceito situado na fronteira entre o mental e o somático, como o representante psíquico dos estímulos que se originam dentro do organismo e alcançam a mente" (Freud, 1915, p.99).
} 
Freud considera, dessa forma, que o ato de mamar com deleite ou mesmo o ato de sugar o dedo constituem elementos consideráveis para apontar as características essenciais de uma manifestação sexual infantil. A finalidade inicial, vinculada à necessidade de alimentarse, cede lugar a um “comportamento" que não está mais vinculado à nutrição, já que a criança suga várias coisas além do seio materno, tais como a mamadeira, a chupeta, o dedo. A atividade de sugar, determinada a princípio por uma necessidade biológica fundamental de alimentação, é uma fonte de prazer e faz com que os lábios do bebê se transformem numa zona erógena, origem de uma pulsão parcial.

Freud assinala que o corpo possui zonas erógenas, que seriam regiões corporais para além da genital e sede das sensações sexuais infantis de prazer, indicando aí a boca e o ânus. A vida psíquica das crianças seria dotada desde o seu início, de acordo com Freud (1905), de uma dimensão sexual, marcada pela disposição "perverso polimorfa". É chamada de perversa por se ligar a objetos parciais, e de polimorfa por se manifestar individualmente sob inúmeras formas, levando à obtenção de satisfação das múltiplas zonas erógenas do corpo. A sexualidade infantil caracterizar-se-ia, portanto, por: não ser objetal, ser autoerótica, prégenital, não ter ligação alguma com a reprodução e não fazer hierarquia entre as zonas erógenas. Freud nos fornece exemplos dessa sexualidade infantil nas seguintes afirmações:

As crianças trazem ao mundo com elas germes de atividade sexual, que já gozam de satisfação sexual quando começam a alimentar-se e que persistentemente buscam repetir a experiência na conhecida atividade de 'sugar o polegar'. (Freud, 1905/1996, p. 239)

A obstinada persistência do bebê em sugar dá prova, em estágio precoce, de uma necessidade de satisfação que, embora se origine da ingestão da nutrição e seja por ela instigada, esforça-se todavia por obter prazer independentemente da nutrição e, por essa razão, pode e deve ser denominada de sexual. (Freud, 1940/1996, p. 179)

O infantil, nesse sentido, deixa de ser apenas uma versão da sexualidade adulta, passando a ser o modo como Freud começa a nomear a sexualidade própria ao ser humano, seja ela a de um adulto ou de uma criança.

O saber da época sobre a sexualidade tinha como referência básica o conceito de instinto sexual, entendido como um padrão fixo e invariável de comportamento, comum a todos os indivíduos de uma mesma espécie, voltado para um objeto específico e prédeterminado de satisfação, que o é precisamente por garantir que sua finalidade seja alcançada. Freud substituiu o conceito de instinto e propôs o conceito de pulsão, sendo esta concebida como independente de um objeto fixo ou pré-determinado (Freud, 1905/1996). 
Apenas a título de nota, a pulsão, cujo objeto é variável, visa a satisfação e exige o trabalho psíquico permanente e constante, não existindo sujeito para quem a pulsão não se coloque como exigência de trabalho, seja na forma do recalque, seja na dos outros destinos da pulsão, descritos mais tarde, em 1915, por Freud em As Pulsões e suas Vicissitudes. Por meio dessas "descobertas", Freud "aponta para um sujeito que escapa ao controle da educação, pois não é possível domesticar as pulsões" (Priszkulnik, 2009, p. 17).

Tendo em vista que a sexualidade é perversa, Freud foi levado, a partir de suas próprias reflexões, a investigar a vida sexual das crianças, mais exatamente os fatores que influenciam a constituição da sexualidade, em virtude de uma ideia que começava a se esboçar de que a sexualidade dos neuróticos permanece num estado infantil ou é trazida de volta a ele (Freud, 1905/1996). O infantil da história de cada um comporia, assim, a base psíquica de qualquer sujeito.

Ao trazer para o centro da discussão a sexualidade infantil como algo amplo e fundamental, Freud revela a existência de um corpo erógeno, no qual é inscrito o olhar e o cuidado do Outro. O circuito pulsional, construído no corpo da criança a partir da relação significativa com este outro que dela cuida, rapidamente suplanta e significa o funcionamento biológico.

Para Lacan, a organização subjetiva da criança não acontece naturalmente, não é da ordem do biológico, mas sim construída e marcada pelo desejo do Outro primordial que inscreve o sujeito numa ordem filiatória. $\mathrm{O}$ autor nos fala da maneira peculiar por meio da qual um ser sai do registro puramente biológico para entrar num "campo de significações" vindas do campo do Outro (Lacan, 1953/1998).

O que isso quer dizer? Significa que quando uma criança chega ao mundo, ela já foi falada antes de falar por si própria, já foi desejada, imaginada e idealizada, marcas fundantes de sua constituição, que inevitavelmente estão impressas e inscritas em seu corpo e resultarão em sua subjetividade, seu desejo próprio (Bernardino, 2006). A criança representa algo para ambos os pais em função de cada história particular e, por essa razão, ela vem ao mundo com um lugar marcado simbolicamente por sua filiação, pela cultura e pela sociedade na qual está inserida, enfim, por nascer inserida na linguagem.

Como parte deste banho de linguagem que recebe ao nascer, o bebê passa a ter um lugar na família que o acolhe. Esse lugar deve ser entendido em sua dimensão metafórica - não se trata somente de ter um quarto, um berço ou um nome, mas de ocupar uma posição subjetiva, da fazer uma diferença com sua chegada, de modificar as posições familiares estabelecidas até então. É um lugar pleno de determinações também simbólicas. Além de sua herança genética, 
herda também - simbolicamente - os acontecimentos, as experiências significativas vividas por seus familiares e antecedentes, a cuja história vem dar continuidade. (Bernardino, 2006, p. 27)

Importante sublinhar que a chegada real da criança, como observa Priszkulnik (2009), nunca corresponde exatamente àquilo que foi imaginado pelos pais. Os pais sempre idealizam seu filho, atribuindo-lhe os mais diversos adjetivos e competências, como educado, obediente, bom aluno, inteligente, organizado, atributos com os quais denominam a perfeição.

Como é impossível para qualquer ser humano atingir a perfeição, quanto mais se espera de uma criança, mais ela pode "fracassar", e esse fracasso pode ser até "saudável", na medida em que fracassar diante de um ideal inatingível é a condição de buscar um caminho próprio, de buscar usufruir suas características específicas e singulares. (Priszkulnik, 2009, p. 20)

Tais expectativas dizem respeito ao narcisismo envolvido em qualquer relação e têm a ver com a idealização do outro. As fantasias parentais que envolvem o narcisismo ganham contornos próprios em uma cadeia de significantes que se particulariza para cada casal parental (Voltolini, 2011a). Referindo-se aos pais, Freud (1914a/1996) observa que estes

acham-se sob a compulsão de atribuir todas as perfeições ao filho. . . e de ocultar e esquecer todas as deficiências dele. . . A criança concretizará os sonhos dourados que os pais jamais realizaram. . . . O amor dos pais, tão comovedor e tão infantil, nada mais é senão o narcisismo dos pais renascido, o qual, transformado em amor objetal, inequivocadamente, revela sua natureza anterior. (p. 108)

Podemos, portanto, concluir que a criança da qual nos fala a Psicanálise não equivale àquela inocente e ingênua que estaria atravessando um período de tranquilidade e calmaria, mas sim uma criança portadora de sexualidade, desejante e submetida às leis da linguagem, "capaz da maior parte das manifestações psíquicas de amor, por exemplo, a ternura, a dedicação e o ciúme" (Freud, 1905/1996, p. 139), além das vivências de conflitos, contradições e desejos.

Lajonquière (2003) refere-se à infância como o "tempo de espera a ser fruído por seres mais ou menos pequenos" (p. 146), uma espécie de quarentena do mundo adulto, que pode ser qualificada como uma constante histórica e sociológica. Isso é importante de ser salientado, visto que o mundo adulto sempre previu um tempo de espera para os pequenos, independentemente das representações e sentimentos nutridos por eles. Com o termo "seres pequenos", o que o autor pretende assinalar é que a condição da criança não é somente temporal, mas de desproporção em relação à dos adultos. Quando esse "ser pequeno", que, como coloca Lajonquière (2003), temos o hábito de chamar de criança, chega ao mundo, o adulto já o habita há algum tempo. Isso instala uma diferença e um desencontro no real do tempo entre gerações, o que moverá o devir adulto a se endereçar à criança, demandando-lhe 
abandonar sua "condição estrangeira de infans"16 (Lajonquière, 2006, p. 7) e apostando no desdobramento dessa diferença posta na origem. Segundo o autor, tal processo é devidamente chamado de educar, isto é, transmitir "marcas simbólicas" que permitam à criança usufruir de um lugar a partir do qual possa se lançar no mundo pela via desejante. No momento em que o infans torna-se adulto, "a infância passa a existir como perdida, embora o resto inexorável do encontro de uma criança com o mundo adulto, em parte, inscreva-se psiquicamente como desejo sexual e infantil" (Lajonquière, 2003, p. 145).

Considerar um tempo de espera para a infância, durante o qual algo se desenrola, pode ser erroneamente relacionado a uma teoria de desenvolvimento psíquico em que haveria etapas sucessivas a serem alcançadas e superadas. Por essa razão, a Psicanálise não fala em desenvolvimento e sim em constituição do sujeito, pois quando a criança passa de objeto para sujeito, algo se constitui e institui uma diferença no tempo posterior. Enquanto seres falantes, de acordo com Lacan, a constituição subjetiva ocorre no laço com o outro, tornando impossível pensar uma criança dentro de parâmetros de desenvolvimento como se fosse um processo autônomo e independente de seu meio familiar, social, cultural. A respeito disso, Lajonquière (2003) escreve:

Ambos os termos, infans e adulto, não são pontos de uma linha genético-evolutiva rumo a uma razão mais ou menos iluminada, conforme postulam as clássicas psicologias do desenvolvimento - herdeiras paradoxais do ideário iluminista -, mas são posições no discurso com relação ao desejo - à palavra do outro. [grifos do autor] (p. 144)

Um último aspecto que merece ser enfatizado diz respeito à relação entre um adulto e uma criança. Segundo Priszkulnik (2009), para além das concepções e preconceitos a respeito da criança, vale ressaltar que, dependendo da forma como o adulto a idealiza e a ela se endereça, isso revela também o ideal que ele tem construído para si próprio, seja ele de pai, professor, médico etc. Nas palavras da autora:

Pensar na criança implica necessariamente o adulto com suas concepções ou com seus preconceitos em relação à infância. Construir um ideal para a criança implica necessariamente construir um ideal para o adulto. Se existe a ideia da criança como "um adulto em miniatura", o adulto é o padrão a ser atingido e, consequentemente, a criança pode ser vista como "inferior" enquanto não atingir o padrão esperado. Se a criança é vista como "uma tábula rasa", ela é vista como "um pedaço de barro" (algo "menor"), que precisa ser moldado pelo adulto provedor e protetor. Se ela é vista como "inocente", ela precisa da proteção do adulto e

\footnotetext{
${ }^{16} \mathrm{O}$ termo estrangeiro é utilizado por Lajonquière referindo-se a condição na qual o adulto toma a criança quando esta chega ao mundo. Segundo o autor assim deve ser a filiação simbólica de humanização, caso contrario, se a criança é tomada como alienígena ou selvagem, não há uma aposta no desdobramento desta diferença posta na origem e as conseqüências disto para a estruturação do sujeito são preocupantes (comunicação pessoal, 10 de abril de 2009).
} 
da disciplina imposta pelo adulto para não se deixar corromper pelas tentações do mundo. Assim, independentemente de como a criança é vista, existe o padrão de adulto a ser atingido. Dito de outra maneira, o adulto idealiza a criança sem perceber que também está construindo um ideal para ele; pode ser um ideal de pai ou mãe, de aluno(a), de professor(a), de trabalhador(a), etc. (Priszkulnik, 2009, p. 21)

Posto isso, os alunos têm, assim, que se deparar com a investidura de seus professores e pode ser que contem com a sua compreensão e simpatia pelo fato de representá-los narcisicamente ou, ao contrário, com a sua antipatia e aversão, o que em última instância relaciona-se com a transferência ${ }^{17}$, o modo particular como cada criança afeta cada professor.

Consideramos valioso destacar isso, pois ao pensar nos professores e no objetivo deste trabalho, tentaremos compreender qual o ideal de criança é esperado. O professor idealiza apenas a criança disciplinada, estudiosa, que participa? Será que comportamentos "turbulentos" característicos daquilo que vem sendo entendido como TDAH causam repulsa e marcam o que entendemos por profecias autorrealizadoras na trajetória escolar de certas crianças? Não pretendemos responder a estas perguntas, mas apenas a título de hipótese compreensiva achamos oportuno pensar em tais questões por considerar que elas favorecerão a análise das entrevistas e a leitura do modo como esses professores significam a criança agitada e desatenta em sala de aula.

Isso posto, se é o adulto que ao se endereçar a uma criança se implica na constituição subjetiva de uma infância, é muito importante considerar como se organizam os discursos adultos hoje e qual o lugar dado a eles a criança. Assim, como ressalta Kupfer (2007), "a realidade humana está recortada pelo significante ${ }^{18}$, então o significante 'criança' será também uma criação da linguagem sobre algo a que chamamos suporte biológico" (p. 36).

2.4 Panorama histórico do surgimento da escola no Brasil

A apresentação que se segue pretende destacar sucintamente o histórico das escolas no Brasil. Não é de nosso interesse elencar exaustivamente a sucessão de fatos e de

\footnotetext{
17 "Processo inconsciente que faz com que uma dada pessoa funcione para nós, mais de acordo com uma suposição que temos dela do que a partir de seus atos ou inclinações reais" (Voltolini, 2011a, p.33).

${ }^{18}$ Significante é um termo da Lingüística saussureana empregado por Lacan para se referir aos fatos de linguagem. Lacan (1988), em seu Seminário IX diferencia, o significante do signo: enquanto um signo representa algo para alguém, um significante representa um sujeito para outro significante. O significante é para a Psicanálise o "elemento fundante do discurso que determina os atos, as palavras e o destino do sujeito, à sua revelia e à maneira de uma nomeação simbólica (Roudinesco, 1998, p.708).
} 
acontecimentos que levaram ao desdobramento da escola tal como a enxergamos atualmente. Todavia, consideramos oportuno pontuar alguns aspectos para melhor situar o leitor diante do cenário que temos hoje nas escolas particulares e de que modo isso se articula com a discussão feita na sequência.

2.4.1 A situação das escolas na Europa na época do descobrimento do Brasil

No início da colonização brasileira, a Europa se encontrava no auge da época renascentista e as atividades comerciais despontavam enquanto a migração das zonas rurais para as cidades provocava um surto de urbanização. No século XVII, conforme discutido anteriormente, foi que se ganhou consciência efetiva - e irrefutável - de que as crianças eram seres diferentes dos adultos e que precisavam de um tipo especial de proteção - para o bem delas e da própria sociedade. Os primeiros pedagogos, se assim os podemos nomear, defendiam que a disciplina era o único meio de proteger as crianças do mundo corrompido e de prepará-las para uma existência de hábitos virtuosos. Com um forte sentimento religioso amalgamado, consideravam que os professores tinham as almas dos alunos a seu encargo, sendo responsáveis pela conduta moral das crianças e, indiretamente, dos futuros adultos que viriam a se tornar. Preocupada com a difusão da fé e com a educação religiosa, as ordens existentes, particularmente a dos jesuítas, criaram um sistema educacional que transmitia às classes dominantes uma educação clássica e humanista, como era o ideal europeu na ocasião (Oliveira, 2004).

A revolta de algumas sociedades contra a ação da Igreja Católica resulta na Reforma, que no século XVI apresenta Lutero se dirigindo aos pais por verificar que eles estavam desmotivados para enviar os filhos à escola. A falta de prestígio da vida religiosa levou-os a se preocupar em preparar os filhos para as profissões da época. Por isso, Lutero escreve em 1530 "Uma Prédica para que se Mandem os Filhos à Escola", a fim de conscientizá-los quanto à importância e, ao mesmo tempo, convocá-los a investirem na educação das crianças e dos jovens.

Este foi um período intenso, marcado por desafios e mudanças, pois o homem do século XVI já não se contentava mais com as explicações religiosas para as questões da vida, que até então haviam sido suficientes. O mundo laico começava a sobrepor-se ao mundo religioso e os anseios por renovação circulavam em todos os âmbitos da sociedade. (Santos, 2008, p. 29). 
No século XVI, percebe-se que as sociedades culturalmente mais avançadas procuram educação para os seus filhos nas escolas que começavam a se multiplicar fora das ordens religiosas, tendo surgido as primeiras escolas laicas após a Idade Média. Importante ainda considerar nesta época o fortalecimento de um grupo social juntamente com o crescimento populacional, as atividades de comércio, o fluxo migratório e a especulação financeira: a burguesia (Mousnier, 1957).

As escolas que despontam surgem similares às escolas que, hoje se considera, foram ligadas a este fortalecimento e crescimento da burguesia, tratando da educação dos filhos da classe economicamente dominante. A educação dos filhos da nobreza, de reis e imperadores continuava sendo exercida por tutores nomeados, e os filhos dessa classe não eram a priori os frequentadores da escola laica ou religiosa.

Especificamente em Portugal, onde a época do descobrimento criou um grande incremento nas atividades comerciais em função da exploração da costa da África, do açúcar e da venda de especiarias que traziam os rendimentos necessários para enriquecer a burguesia das cidades, principalmente Lisboa, via-se um movimento oposto.

A partir do século XVI, por motivos que são ainda os da fé e do Império, quando a Europa ingressa, pelo rompimento da concepção do mundo medieval, no surto do humanismo e renascimento e da descoberta das ciências positivas, das técnicas, e ao mesmo tempo em que vemos a Europa orientada ao espírito crítico individualista, pela afirmação de um novo homem centrado na natureza, e no plano espiritual, a afirmação da liberdade de pensamento e da autonomia religiosa, contra a autoridade da Igreja, Portugal coloca-se no movimento da Contra-Reforma, preservando sua fé. Empenho este que moverá Portugal à obra da colonização. (Caminha, 2006, p. 10)

Embora na Europa Central ocorresse o fortalecimento das escolas laicas, inspiradas pelo humanismo, pela descoberta das ciências positivas e pela "afirmação da liberdade de pensamento e da autonomia religiosa, contra a autoridade da Igreja", em Portugal se fortaleciam as ordens religiosas como elementos concentradores das escolas, principalmente pela ação da Companhia de Jesus, cujos membros eram os jesuítas (Caminha, 2006, p. 10).

\subsubsection{A situação das escolas no Brasil no período colonial}

A história da educação no Brasil se inicia em 1549 com a chegada dos primeiros padres jesuítas, inaugurando uma época que deixaria marcas profundas na cultura brasileira. 
Motivados pela divulgação do evangelho e a propagação da fé cristã, durante quase 200 anos os jesuítas foram praticamente os únicos educadores do Brasil colônia e o governo português não interveio nem se preocupou com o ensino. Fundaram nas cidades litorâneas e próximas ao litoral, como São Paulo, inúmeras escolas de ler, contar e escrever. Entretanto, a prioridade dos jesuítas era a escola secundária, grau do ensino onde eles organizaram uma rede de colégios reconhecida por sua qualidade.

As escolas religiosas jesuíticas no Brasil visavam principalmente à educação dos filhos dos colonos e da população local, formada por indígenas e filhos de imigrantes (Oliveira, 2004). O Colégio de São Paulo de Piratininga, que abrigava a moradia dos religiosos, as salas de aula, a igreja e demais instalações, caracterizou-se como o centro de educação da colônia.

[Os jesuitas] rumaram para o sul, fundando colégios que se expandiram amplamente e nos quais funcionavam escolas elementares, base do sistema colonial de educação, que funcionavam onde quer que existisse um convento, os índios aprendiam a ler, escrever, contar e falar o português. (Caminha, 2006, p. 12)

A reação da população indígena à doutrina dos jesuítas e aos ensinamentos ministrados a seus filhos não foi tranquila. Houve resistência por parte dessa cultura, ao mesmo tempo em que os bandeirantes paulistas aprisionavam os índios na procura por escravos e entravam em conflito com os catequizadores. Diversas revoltas contra os jesuítas ocorreram em São Paulo, Santos e Rio de Janeiro, com os colonos invadindo as escolas da Companhia de Jesus.

Desde o século XVI, a Companhia de Jesus conseguiu que o governo proibisse tal prática [escravização]. Todavia grupos importantes de plantadores de cana, donos de engenho e, posteriormente, bandeirantes que obtinham grandes lucros com a escravização dos "negros da terra" consideravam sua proteção uma ruína para a Colônia. (Del Priore \& Venancio, 2010, p. 32)

Em 1759, por diversos motivos, mas principalmente pelas revoltas nas colônias, os jesuítas foram expulsos de Portugal e de suas colônias, ocorrendo com isso uma falta quase total de escolas e de educadores em todo o Brasil. Somente em 1808, com a fuga da família real portuguesa para o Brasil e a mudança da sede do reino de Portugal, a educação e a cultura tomaram um novo impulso, com o surgimento de novas escolas laicas e religiosas (Soneville \& Marcílio, 2005). 
2.4.3 A situação das escolas no Brasil no período do Império

Com a chegada de D. João VI e da corte lisboeta ao Brasil, em 1808, a paisagem cultural do país passou por grandes transformações. Em sua obra educacional, visou atender principalmente as necessidades dos membros da família real e de sua corte. Segundo Oliveira (2004), “o país passa a viver um ambiente de efusão cultural, em que se destacam a criação do Museu Real, do Jardim Botânico, da Biblioteca Pública e da Imprensa Régia. No setor educacional, surgem os primeiros cursos superiores" (p. 947).

A independência do Brasil levou ao início da normatização das escolas, com a Lei Geral de Ensino de 1827, determinando a criação de escolas de primeiras letras nas cidades. Ainda que persistisse a falta de salas de aula, de professores preparados e de material didático, as escolas populares aos poucos foram sendo implantadas. Essa Lei Geral do Ensino, que vigoraria até 1946, determinou a criação de "escolas de primeiras letras em todas as cidades, vilas e lugarejos" (artigo $1^{\circ}$ ) e "escolas de meninas nas cidades e vilas mais populosas" (artigo XI).

D. Pedro I, por Graça de Deus e unânime aclamação dos povos, Imperador Constitucional e Defensor Perpétuo do Brasil: Fazemos saber a todos os nossos súditos que a Assembleia Geral decretou e nós queremos a lei seguinte:

Art. $1^{\circ} \mathrm{Em}$ todas as cidades, vilas e lugares mais populosos, haverá as escolas de primeiras letras que forem necessárias.

Art. 11. Haverá escolas de meninas nas cidades e vilas mais populosas, em que os Presidentes em Conselho, julgarem necessário este estabelecimento. (Lei Geral do ensino, 1827, 15 de outubro)

No ano de 1834, foi realizada a reforma do sistema educacional, que criava o ensino elementar, secundário e de formação dos professores a cargo das províncias, enquanto o poder central cuidaria do Ensino Superior.

Ainda durante todo o século XIX se desenvolveu a tendência da criação de escolas religiosas, o que já não ocorria na Europa e nos Estados Unidos, onde o ensino laico se desenvolveu significativamente. Dentre essas instituições de ensino, figuram o Colégio São Luís (1867), o Colégio Caraça em Minas Gerais (1820), Colégio Mackenzie (São Paulo, 1870), Colégio Americano (Porto Alegre, 1885), Colégio Internacional (Campinas, 1873), entre outros. 
Ao final do Império, o quadro geral do ensino era o seguinte: poucas escolas primárias (com 250 mil alunos para um país com cerca de 14 milhões de habitantes, dos quais $85 \%$ eram analfabetos), liceus provinciais nas capitais, colégios particulares nas principais cidades, alguns cursos normais e os cursos superiores que forjavam o projeto elitista (para formação de administradores, políticos, jornalistas e advogados), que acabou se transformando num elemento poderoso de unificação ideológica da política imperial. (Oliveira, 2004, p. 949)

\subsubsection{O século da escola pública no Brasil 1870 - 1980}

No final do século XIX, começou a se redesenhar a estrutura da sociedade brasileira, com afirmação da burguesia.

$\mathrm{Na}$ transição republicana, com a adesão de parte da elite intelectual aos ideais do liberalismo burguês, é atribuída à educação a tarefa heroica de promover a reconstrução da sociedade. A primeira Constituição da República, de 1891, institui o sistema federativo de governo e, consequentemente, a descentralização do ensino. (Oliveira, 2004, p. 949)

Com a proliferação do ideal republicano, segundo o qual o Estado é o responsável pela manutenção e o desenvolvimento da instrução pública, a escola começou a fazer parte da vida das cidades, com prédios próprios e bem aparelhados. A fim de preparar os professores, instalaram-se Escolas Normais públicas, como a Escola Normal Secundária, da Praça da República, com sua escola primária Caetano de Campos.

Um aspecto importante desta época a ser destacado nas escolas primárias foi a criação dos denominados Grupos Escolares. No território brasileiro estes Grupos, criados inicialmente no Estado de São Paulo em 1893 como uma proposta de reunião de escolas isoladas agrupadas segundo a proximidade, foram responsáveis por um novo modelo de organização escolar no início da República e reuniam as principais características da escola graduada.

Os grupos escolares constituíram um fenômeno tipicamente urbano, já que no meio rural ainda predominou as escolas isoladas por muito tempo. O Grupo Escolar foi uma escola eficiente para a seleção e a formação das elites. A questão do ensino para as massas populares só esteve presente na reforma paulista de 1920. Os grupos escolares também eram conhecidos como escolas graduadas, já que possuíam turmas seriadas. (Saviani, 2006, p. 244)

A respeito do ensino naquela época, Souza R. F. (2004) comenta:

O ensino primário era ministrado em quatro anos, com um programa enciclopédico com matérias que proporcionavam uma educação integral - a educação física, intelectual e moral. Foi ainda um projeto cultural a favor da nação, o qual educava mais do que instruía. Ela reportava a uma clara concepção de ensino; educar pressupunha um compromisso com a 
formação integral da criança que ia muito além da simples transmissão de conhecimentos úteis dados pela instrução e implicava essencialmente a formação do caráter mediante a aprendizagem da disciplina social - obediência, asseio, ordem, pontualidade, amor ao trabalho, honestidade, respeito às autoridades, virtudes morais e valores cívico-patrióticos necessários à formação do espírito de nacionalidade. (p. 127)

O final do século XIX e início do século XX surge como a época da escola pública, universal e gratuita nos países desenvolvidos e também no Estado de São Paulo. Nessa ocasião, Rui Barbosa criticava violentamente o Estado por relegar a educação popular, sem dar à formação do povo sua devida importância, demandando por uma reforma radical do ensino público (Barbosa, 1947).

A partir de 1920, de modo a atender a grande demanda por escolas, o estado permitiu o aparecimento de escolas particulares de todo o tipo, sem controle nem fiscalização, embora algumas delas, em grande parte em mãos de ordens religiosas, tenham contribuído para a renovação e modernização do ensino.

Foi o início do dualismo vigente no sistema educacional brasileiro: escolas privadas, caras, de alta qualidade, para as crianças de elite e classe média, e escolas públicas ou privadas, de baixo custo e baixa qualidade para as demais. (Soneville, 1992, p. 109)

Um aspecto importante a ser considerado neste período foi o efeito do fluxo migratório de europeus e outras nacionalidades, dando início à instalação de escolas destinadas a atender a classe média representada pela evolução desses imigrantes e caracterizando determinadas escolas com o país de origem. Como exemplo, podemos citar: o Colégio Porto Seguro, de 1930, de origem alemã; o Colégio Dante Alighieri, de 1911, da colônia italiana e o Liceu Pasteur, de 1908, da colônia francesa.

Embora as escolas particulares iniciassem a sua disseminação, as escolas públicas ainda detinham o status de liderança no ensino e educação no Estado de São Paulo.

Segundo Oliveira (2004), nesta época se desenvolveu a pedagogia pragmática da Escola Nova, baseada no pensamento do norte-americano John Dewey, que propunha um modelo

com tendências a produzir privilégios e desigualdades, mas que subsiste pela expectativa de mudança e ascensão social. . . . O pensamento escola-novista foi adotado por diferentes educadores brasileiros da época, com divergências apenas no que diz respeito à orientação geral (revolucionária-reformista ou conservadoramente democrática). (p. 951).

A partir de 1930, com o governo de Getúlio Vargas surgem reformas educacionais mais modernas, correspondentes à introdução do pensamento pedagógico liberal no Brasil e a 
favor de uma resposta eficaz à crescente demanda social por educação (Akkari, 2001). Em 1932, alguns intelectuais brasileiros, como Lourenço Filho, Fernando de Azevedo, Afrânio Peixoto, Cecília Meirelles e Anísio Teixeira, dentre outros, assinam o Manifesto dos Pioneiros da Educação Nova, que reflete o ápice deste movimento. O documento preconizava uma universalização do ensino pelo desenvolvimento de um sistema público de ensino, e o resumo encontra-se a seguir:

Em nosso regime político, o Estado não poderá, decerto, impedir que, graças à organização de escolas privadas de tipos diferentes, as classes mais privilegiadas assegurem a seus filhos uma educação de classe determinada; mas está no dever indeclinável de não admitir, dentro do sistema escolar do Estado, quaisquer classes ou escolas, a que só tenha acesso uma minoria, por um privilégio exclusivamente econômico.

Afastada a ideia de monopólio da educação pelo Estado, num país em que o Estado, pela sua situação financeira, não está ainda em condições de assumir a sua responsabilidade exclusiva, e em que, portanto, se torna necessário estimular, sob sua vigilância, as instituições privadas idôneas, a escola única se entenderá entre nós, não como uma conscrição precoce arrolando, da escola infantil à universidade, todos os brasileiros e submetendo-os durante o maior tempo possível a uma formação idêntica, para ramificações posteriores em vista de destinos diversos, mas antes como a escola oficial, única, em que todas as crianças, de 7 a 15 anos, todas ao menos que, nessa idade, sejam confiadas pelos pais à escola pública, tenham uma educação comum, igual para todos.

A educação nova, alargando sua finalidade para além dos limites das classes, assume, com uma feição mais humana, a sua verdadeira função social, preparando-se para formar a hierarquia democrática pela "hierarquia das capacidades", recrutadas em todos os grupos sociais, a que se abrem as mesmas oportunidades de educação. Ela tem, por objeto, organizar e desenvolver os meios de ação durável com o fim de dirigir o desenvolvimento natural e integral do ser humano em cada uma das etapas de seu crescimento, de acordo com uma certa concepção de mundo.

A seleção dos alunos nas suas aptidões naturais, a supressão de instituições criadoras de diferenças sobre base econômica, a incorporação dos estudos do magistério à universidade, a equiparação dos mestres e professores em remuneração e trabalho, a correlação e a continuidade do ensino em todos os graus e a reação contra tudo que lhe quebra a coerência interna e a unidade vital, constituem o programa de uma política educacional, fundada sobre a aplicação do princípio unificador que modifica profundamente a estrutura íntima e a organização dos elementos constitutivos do ensino e dos sistemas escolares. (Bello, 2001, s/p)

No Estado Novo da Era Vargas as ideias registradas no Manifesto não encontram o eco desejado. Nessa época, as escolas particulares já estavam voltadas para atender as classes mais ricas, embora ainda competissem com as escolas públicas de alta qualidade.

Com a nova constituição brasileira, em 1946, surge uma discussão em torno do Plano Nacional de Educação (PNE), que pretendia unificar as redes de ensino segundo diretrizes educacionais, porém, sem tirar a autonomia dos estados. Entre as décadas de 50 e 60, ocorreu no país um forte movimento no cenário educacional, com grupos defensores da escola pública 
e grupos defensores da escola privada, o que culmina, em 1961, com a promulgação da primeira Lei de Diretrizes e Bases da Educação Nacional. Embora tenha reforçado no plano legislativo a escola pública, essa lei frustrou o grupo liberal e não constituiu um avanço sensível no sistema público de ensino (Akkari, 2001).

No período que vai da queda do Estado Novo, em 1945, até 1964, quando se inaugurou um novo período autoritário, o sistema educacional brasileiro passou por mudanças significativas, destacando-se a instalação do Conselho Federal de Educação, em 1961, campanhas e movimentos de alfabetização de adultos, além da expansão do ensino primário e superior. O trabalho pioneiro do Movimento de Educação Básica (MEB) e a atuação de Paulo Freire foram decisivos para tal movimento da educação popular. De 1951 a 1980, houve um nítido apoio às escolas públicas, mesmo durante o regime militar das décadas de 60 e 70 . Muitos dos políticos e personalidades daquela época tinham se formado em escolas públicas, como o Colégio Caetano de Campos já mencionado. Entretanto, neste período se intensificava o dualismo já citado anteriormente e se solidificavam as escolas particulares para a elite e classe média alta (Akkari, 2001).

Com a Lei 4.024/61, as escolas particulares ganharam autonomia para definir o método pedagógico. Neste período, são abertas diversas escolas particulares, algumas sem ligação com instituições religiosas, e aparecem também as escolas experimentais influenciadas pelo movimento da Escola Nova. Em plena ditadura política, os pedagogos estudavam métodos pedagógicos para garantir o sucesso escolar, apoiados na puericultura e alicerçados na medicina e nas teorias psicológicas. Estas últimas, como comentado em outro momento do trabalho, exerceram influência direta nas práticas escolares, graças aos estudos do desenvolvimento e avaliações, que buscavam um ensino ajustado à criança, o que ia ao encontro dos ideais políticos de então.

A partir dos anos 80, de acordo com Akkari (2001), com o progressivo retorno à democracia, o debate passou a girar em torno da democratização do ensino e da preocupação em eliminar a evasão escolar. Várias medidas foram votadas, entre elas a Nova Lei de Diretrizes e Bases da Educação Nacional, em 1996.

Este breve sobrevoo pelo histórico da constituição do sistema educativo no Brasil nos revela o seguinte: partindo, primordialmente, do monopólio das ordens eclesiásticas, a educação formal passou a ser organizada pelo Império e pela República, seguindo a modernização e o desenvolvimento econômico do país. Fica claro, no entanto, que o Estado "nunca quis ou pode controlar o conjunto do processo de escolarização de massa ao longo do 
século XX. O ensino particular constitui-se progressivamente como a única opção para os filhos da elite social"' (Akkari, 2001, p. 166).

Segundo análise de Akkari (2001), a chamada "fragmentação do sistema educativo brasileiro", representada por sua heterogeneidade, acentua ainda mais as desigualdades sociais, além de comprometer consideravelmente o desenvolvimento social e econômico do país. Os principais fenômenos responsáveis por isso seriam: "a privatização neoliberal, a descentralização e o pacto das elites" (Akkari, 2001, p. 173).

2.5 A escola particular de elite no Brasil: os efeitos do poder econômico

A partir de 1980, com a abertura política e o vertiginoso aumento da rede escolar, fica nítido que a qualidade do ensino nas escolas particulares era significativamente superior à qualidade do ensino nas escolas públicas. Razões para essa queda da escola pública são objeto de inúmeros estudos e análises, que procuram encontrar os motivos da atual situação.

Não é objetivo do presente trabalho, no entanto, entrar nessa discussão. Na pesquisa de campo, como se sabe, foi tomado como objeto de estudo professores de escolas particulares de elite ${ }^{19}$ da cidade de São Paulo. As escolas escolhidas possuem como "clientela" a classe dominante ${ }^{20}$, com maior concentração de riqueza do país, e figuram entre as melhores da cidade, conforme apontam os meios educacionais, a mídia, avaliações que têm por base as notas no exame do Exame Nacional do Ensino Médio ${ }^{21}$ (ENEM) e a aprovação em vestibulares de universidades prestigiadas.

Os aspectos da escolarização dessa parcela ínfima da sociedade (por volta de $0,5 \%$ ) mas que condiciona a economia, a cultura e a política - emergiram apenas recentemente como temática específica de estudo, ainda que possuam características singulares que tenham muito a revelar sobre a formação da opinião pública por meio da grande mídia e favoreçam

\footnotetext{
${ }^{19}$ Estamos advertidos sobre a controvérsia do termo elite, pelo fato dele ser amplo e ambíguo. Todavia, o utilizamos neste texto em referência a elite econômica, que sabemos nem sempre ocupar uma posição privilegiada por competência ou mérito.

${ }^{20}$ Apesar de estarmos cientes da imprecisão do termo classe dominante, optamos por reproduzir as expressões utilizadas pelos autores citados.

${ }^{21}$ Aspectos referentes a esta escolha poderão ser melhor compreendidos no capítulo que trata da metodologia da pesquisa. A respeito da confiabilidade no ENEM para ditar quais seriam as escolas com melhor avaliação, ainda que não entrando no mérito da ampla discussão por detrás desta designação, cabe parafrasear Bordieu (1998) pois sabemos que "não é jamais possível, em todo caso, dizer com segurança quem, entre o agente e a instituição, escolhe realmente; se é o bom aluno que escolhe a escola ou se é a escola que o escolhe" (p.198). Por esta razão, consideramos duvidosa a posição destas escolas no ápice das hierarquias escolares segundo o Enem pela manutenção do padrão de desempenho.
} 
importantes tomadas de decisão sobre as grandes questões econômicas e culturais que afetam o país. Daí decorre o valor de estudar as classes abastadas para compreender os processos de produção e reprodução social. Entre os estudos sobre o tema, destacam-se a coletânea organizada por Almeida e Nogueira (2003), A Escolarização das Elites: Um Panorama Internacional de Pesquisa, o trabalho de Brandão (2003), Dallabrida (2001) e Akkari (2001).

Histórica e concretamente, deparamo-nos, no Brasil, com uma sólida relação entre domínios econômico, político e ideológico por parte de minorias poderosas que desenvolvem contínuo trabalho de legitimação e reforço da posição que ocupam, valendo-se das instituições da sociedade civil, de aparelhamento do Estado e de peculiares estratégias econômicas arregimentando a sociedade em torno de um conjunto de idéias e valores que sustentam. (Almeida e Nogueira, 2002, p. 173)

No Brasil, as questões envolvidas na formação escolar da "elite" foram, durante muito tempo, suplantadas pela preocupação com a qualidade da escola pública e com a universalização do ensino básico. Centenas de obras, algumas das quais foram citadas ao longo deste trabalho, voltadas para a compreensão e análise da escola pública e do fracasso escolar foram publicadas, ao passo que a preocupação com a formação dos muito ricos foi, durante bastante tempo, "negligenciada", se é assim que podemos nos referir ao interesse recente pela temática em questão.

Sabemos que muitas famílias escolhem determinada escola com foco na rede de relações sociais que seus filhos irão manter, ou seja, tendem para uma visão utilitarista e pragmática, deixando, não raras vezes, o ensino e a educação num segundo plano. Como bem atestam Almeida e Nogueira (2002), "esse é o grande trunfo das escolas para os muito ricos: serem empreendimentos comerciais, em princípio, altamente rentáveis, contribuindo, ao mesmo tempo, para a formação e a reprodução da classe dominante” (p. 175).

A partir daí podemos compreender por que para muitos pais a preocupação maior reside em apenas manter o filho na escola, garantindo que ele não seja reprovado e permaneça, assim, com o seu círculo social de amizades, ainda que com o alto custo de um diagnóstico médico psiquiátrico que valide isso - prática corrente em muitas escolas particulares que garantem não reprovar o aluno mediante a apresentação de um laudo que ateste a existência de um transtorno de aprendizagem ou de comportamento.

Notamos o quanto essas escolas estão subjugadas pelos interesses da elite que a frequenta, uma vez que, ao invés de o aluno e de sua família terem que se ajustar à escola, como seria o esperado, é esta última que trabalha para se adequar às exigências da família, da criança, enfim, de todo um grupo economicamente favorecido. Entram nesse rol as leis em 
curso e em trâmite que preveem condições "especiais" de tratamento escolar a crianças com dislexia e TDAH, como por exemplo, um tempo maior e exclusivo para realizar as avaliações, além de todo um aparato fornecido por profissionais "especialistas" que fazem parte da escola e que são, por vezes, nada mais do que um chamariz.

Veremos adiante como esta lógica perversa permite que famílias comprem diagnósticos para seus filhos, pois, assim, eles teriam acesso a uma vida escolar menos exigente e mais flexível, sem ter que se sujeitar à aflição provocada pelas provas, tampouco à angústia de não passar de ano. As consequências disso, como sabemos, são nefastas, pois traduzem a desresponsabilização e desimplicação de todos os personagens do cenário educativo.

Nogueira (2003) destaca ainda que nessas famílias favorecidas financeiramente há uma preocupação maior de inserir o jovem no mundo do trabalho do que no da escola. Os conhecimentos adquiridos nesta última seriam secundários em relação ao interesse de inserção no universo empresarial. Assim, as elites econômicas não precisariam investir "tão pesadamente na escolarização dos seus filhos quanto certas frações das classes médias que devem sua posição social, quase que exclusivamente, à certificação escolar" (Nogueira \& Nogueira, 2002, p. 23). Os autores compreendem que a fuga do fracasso escolar justifica muitas vezes essa escolha e legitima para muitas famílias a matrícula em escolas particulares de menor qualidade, apenas para que o filho não "perca o ano" - isso quando o diploma não é "comprado" no interior da própria escola. Como exemplo do desapreço pela educação escolar, temos a pesquisa de Nogueira (2004) com grandes e médios empresários de Minas Gerais, cujo objetivo foi conhecer as estratégias educativas postas em prática por essas famílias ao longo do processo de escolarização de seus filhos. A autora chega à seguinte conclusão:

Há uma relação com a escola e com o saber predominantemente instrumental. . . em que as finalidades perseguidas são, em sua maior parte, exteriores ao conhecimento em si mesmo e marcadas pelo utilitarismo, como, por exemplo, a obtenção da nota ou do diploma. Um relativo desapreço pelo universo escolar, ao qual corresponde um interesse quase apaixonado pelo mundo empresarial (o mundo das "coisas vivas") e pelos desafios que este lhes coloca, caracteriza esses estudantes. (Nogueira, 2004, p. 141)

Como bem coloca Ballion (1977), sociólogo que se debruçou sobre o tema do insucesso escolar nos meios altamente favorecidos economicamente, "l'argent efface l'échec", ou seja, o dinheiro repara o prejuízo, no caso, o escolar. Essa categoria social dispõe de meios de luta contra o fracasso escolar por meio da reparação ou atenuação deste. Dentro dessa lógica de pensamento, os resultados escolares dos filhos da classe dominante "estariam 
se tornando cada vez mais dependentes dos recursos financeiros e da capacidade estratégica de seus pais, e cada vez menos de seu valor escolar" (Nogueira, 2010, p. 223).

Os pais tentam redirecionar os destinos determinados pelos resultados escolares (com aulas particulares, por exemplo) e se submetem cada vez menos à lógica da instituição escolar (eles fazem de tudo para que seus filhos frequentem a melhor escola). É isso a parentocracia. Ela significa que a escola sofre a concorrência das estratégias dos pais. (Van Zanten e DarchyKoechlin, 2005, citado por Nogueira, 2010, pp. 223-224)

Haveria, portanto, todo um conjunto de dispositivos "para-escolares" e de estratégias utilizadas por essas famílias para promover as melhores oportunidades de êxito escolar para seus filhos. Essas estratégias vão desde aulas particulares e consultas com psicopedagogos até ao que hoje é chamado de "coaching escolar", que consiste no trabalho de um profissional que é uma espécie de mediador entre a escola e o aluno e entre este e seus pais e que busca auxiliar o aluno na rotina e organização dos estudos (Nogueira, 2010). Obviamente que o emprego de tais recursos reduz em muito a incidência do fracasso escolar nas escolas de elite, porém, sabemos que apesar de tudo essas escolas não estão imunes a esse fenômeno, que, parafraseando Lacan ao referir-se ao real, "não cessa de não se inscrever". Àquele que não captou o sentido da frase precedente, recomendamos apenas que a tome como uma inquietação que o mova ao capítulo seguinte, na qual ela certamente se esclarecerá.

A expectativa de algumas famílias que encaminham seus filhos para essas escolas centra-se comumente na construção de amizades e redes de influência. Almeida (2003), dedicando-se ao estudo da elite das escolas paulistanas que atendem a fração da classe dominante, destaca o rígido processo de seleção dos alunos dessas escolas, que visa garantir uma pretensa "homogeneidade do alunado em termos da maneira de viver a escolarização" (p. 34), como reflexo da função exercida pelo sistema educacional na manutenção das desigualdades entre os grupos sociais. Na maior parte das escolas que foram alvo da presente pesquisa de campo, somente filhos de ex-alunos podem ingressar e possuem vaga garantida. Aos demais é reservada uma longa fila de anos de espera e a entrega à sorte de um suposto sorteio que possa vir a ocorrer algum dia.

Consideramos importante destacar a peculiaridade da realidade da elite brasileira quando comparada à elite europeia. Se nos países europeus de primeiro mundo, há uma valorização do capital cultural, o mesmo não acontece no Brasil, que possui uma espécie de “norte-americanização" cultural (Cattani e Kieling, 2007, p. 182). Por esse motivo, os estudos no campo da Sociologia da Educação realizados pelo sociólogo francês Pierre Bordieu (1998) sobre o problema das desigualdades escolares - referência sobre o papel das escolas na 
reprodução e naturalização das situações de classe - possui os seus limites para se pensar na realidade brasileira, especificamente a paulista.

Brandão e Lellis (2003) salientam um "campo simbólico fragmentado na América Latina”, entendendo por isso não só a ausência de um padrão de consumo cultural de bens de alta cultura, mas a apropriação de outras culturas sem que haja a constituição de um padrão cultural próprio. Logicamente há frações específicas da classe dominante que não se encaixam nesta visão e que, ao contrário, valorizam os recursos simbólicos propiciados pela educação formal. Em virtude disso, os autores que se dedicaram a estudar o tema preocupam-se em ressaltar a heterogeneidade das classes dominantes brasileiras.

Assistimos a um crescente protagonismo que as famílias contemporâneas da classe dominante assumem no funcionamento dos próprios sistemas de ensino, por meio de estratégias educacionais tais como as que foram anteriormente destacadas (Nogueira, 2010). Se a teoria proposta por Bordieu nos anos 60 havia sido revolucionária por ter feito uma grande contribuição para a compreensão sociológica da escola, ressaltando o fato de esta não ser neutra, como era difundido até então, o que vemos se esboçar em nossa época, ainda segundo essa mesma lógica, é completamente inusitado. Bordieu (1998) destacara a escola como uma das principais instituições por meio das quais os privilégios sociais se legitimariam e se manteriam. O autor preocupou-se em mostrar como a escola produz as condições de reprodução dos grupos sociais em posição dominante. Petitat (1994), sociólogo da Educação, questiona a Sociologia clássica ao acrescentar que, para além desse papel, a escola também participa ativamente da produção e da transformação desses mesmos grupos ${ }^{22}$. Segundo essa visão, a escola é entendida como parte interessada na gênese de certos grupos sociais, agindo assim como uma instância produtora - e não mais como mera receptora do fatalismo da reprodução - de transformações.

Cabe aqui abrir um parêntese para nos perguntar se a prática diagnóstica corrente no interior das escolas, além de responder a algo que está posto no social, não estaria também produzindo algo novo a serviço dos valores dominantes. Na atualidade, observamos que as

\footnotetext{
${ }^{22}$ Para aquele interessado nesta discussão, indicamos a leitura de "Produção da escola/produção da sociedade: análise sócio-histórica de alguns momentos decisivos da evolução escolar no ocidente", na qual Petitat (1994) nos fornece exemplos da contribuição ativa da escola para as transformações da sociedade. Um exemplo histórico é como as escolas elementares, ao formalizarem o ensino da escrita para "domar" a socialização oral, permitiu que operários alfabetizados pudessem se organizar e tomarem uma consciência de classe que culminaria na Revolução Industrial. As instituições escolares podem, por exemplo, servir o poder constituído enquanto que, inconscientemente e a longo prazo, trabalham para a sua ruína. No Antigo Regime os colégios que professavam fidelidade aos regimes de poder, contribuíam para manter a dominação social e política mas ao mesmo tempo forneciam a burguesia em pleno crescimento uma identidade cultural e um ponto de agrupamento simbólico.
} 
elites econômicas parecem deter o poder de alterar o curso de muita coisa que se desenrola no interior das escolas a seu favor. Segundo a lógica mercadológica capitalista, a educação "cara" é vista como mais um objeto de consumo a ser adquirido no mercado, com um valor de compra e exigência de satisfação do cliente. Ao se colocar como instrumento do discurso capitalista - conceito discutido a seguir -, essas escolas acabam por transformar o saber em mais uma mercadoria. No próximo capítulo, articularemos isso à crise na educação e ao declínio da imago paterna, que levou o sujeito à descrença nos ideais simbólicos a favor de um empuxo a gozar sempre mais em nome de seus direitos.

Diante do exposto, Nogueira (2010) destaca o papel dessas famílias de elite como coprodutoras de uma realidade educacional que as localiza como "atores incontornáveis na orientação da ação educativa" e não apenas como meras usuárias passivas que sofrem a ação do Estado (Van Zanten, 2002, citado por Nogueira, 2010, p. 228).

Tendo, enfim, acompanhado todos os aspectos levantados até o momento em relação à manifestação e ao diagnóstico de TDAH, convocamos a Psicanálise para refletir sobre essa sintomatologia articulada às questões que envolvem a contemporaneidade, conforme será discutido a seguir. 


\section{CONTRIBUIÇÕES DA PSICANÁLISE}

Entre o temor à desordem e a valorização de uma competitividade fundada exclusivamente sobre o exito material, muitos sujeitos preferem entregar-se voluntariamente às substâncias químicas a falar de seus sofrimentos íntimos. O poder dos medicamentos do espírito é assim o sintoma de uma modernidade que tende a abolir no homem não somente seu desejo de liberdade, mas também a ideia mesma de enfrentar $a$ adversidade. $O$ silêncio é então preferivel à linguagem, fonte de angústia $e$ de vergonha. (Roudinesco, 2000)

Para nossa apresentação sobre as contribuições da Psicanálise a fim de se pensar sobre o TDAH no campo educativo, partiremos da distinção inicial entre o que é entendido como transtorno pela Medicina e como sintoma pela Psicanálise. A Psicanálise pode estudar uma criança que apresenta alterações no comportamento (por exemplo, uma agitação motora), pois entende que tais alterações podem ser efeito de modificações na imagem corporal e não no corpo propriamente dito. Freud não contesta a Neurologia, mas afirma que algumas alterações sofridas no corpo referem-se não à anatomia que é conhecida pelo médico, mas à anatomia imaginária do sujeito. Isso nos permite considerar que nem toda alteração de comportamento é uma alteração neurológica, diferentemente do que pretendem defender muitos médicos, psiquiatras, psicólogos e demais profissionais da saúde. Este argumento revela-se fundamental para que, a partir daí, possamos seguir com a definição de alguns conceitos psicanalíticos em Freud e Lacan, que nos fornecerão subsídios para refletir criticamente sobre a maneira como os comportamentos das crianças vêm sendo compreendidos atualmente no interior das escolas.

Posteriormente, discutiremos sobre a crise da autoridade em nossa época e seus efeitos sobre a educação. O mal-estar contemporâneo na educação, efeito do que Freud já havia anunciado como "declínio do pai”, será apresentado adiante, articulado ao conceito de discurso do capitalista, tal como proposto por Lacan. Concluiremos o capítulo nos remetendo ao terceiro ensino de Lacan, mais especificamente ao conceito de real em sua obra, para então convocar a ética da Psicanálise, que advoga pela responsabilização subjetiva. 
3.1 TDAH: transtorno médico ou sintoma analítico?

“E por que a Psicanálise?”, pergunta Roudinesco (2000). E reedita a temática, Moretto (2006): "Porque num tempo de busca desenfreada pela normalização e padronização de comportamentos, a Psicanálise vem para dar lugar para que a subjetividade seja considerada" (p. 48). A hipótese que queremos destacar é a de que a Psicanálise opera num sentido inverso ao do discurso da ciência: interroga ao invés de postular verdades, balança certezas, problematiza ao invés de ser inflexível, reflete criticamente ao invés de se apoiar incondicionalmente em certos argumentos e, principalmente, se interessa pela subjetividade, pelo ser que sofre e não pela doença em si. Parte do princípio de que, ao falar do sujeito, estamos num campo cujas verdades são particulares e cujos sentidos e significados não estão dados a priori.

Para percorrer esse argumento, faz-se necessário apresentar a diferença fundamental que existe entre a noção de transtorno para a ciência médica e o entendimento de sintoma para a Psicanálise. Antes, porém, falaremos a respeito do principal fator que sustenta essa diferença, já que o corpo na Psicanálise não é o mesmo corpo que o da Medicina, ou seja, ele não equivale ao organismo biológico (Priszkulnik, 1993).

$\mathrm{Na}$ Psicanálise, consideramos o corpo erógeno e pulsional, onde está inscrito o olhar do outro. Trata-se de um corpo tecido e humanizado pela linguagem. Em contrapartida, o corpo anatomofisiológico é análogo ao organismo objetivado que é investigado em suas funções e disfunções pela Medicina. Freud, por meio de suas pacientes histéricas, notou que a vivência da corporalidade não passa pela estrutura anatômica corporal, mas sim pela imagem que se tem do corpo e que é de outra ordem (Priszkulnik, 2000).

Frente à especificidade do corpo pulsional, à Psicanálise interessa escutar o que manifesta esse corpo caracterizado pela Medicina como portador de um dito transtorno neurológico e que se apresenta de modo desorganizado, inquieto e distraído: o que se passou na história pulsional da criança? Quais falhas estruturais ocorreram em seu psiquismo que não lhe permitiram significar a experiência vivida e a conduziram a essa manifestação corporal? $\mathrm{O}$ que isso tem a nos dizer sobre as vicissitudes do sujeito? Como este se relaciona com seu sintoma? Que relação estabelece, de onde fala, do que sofre, qual sua posição discursiva, que posição subjetiva assume em relação ao que diz? 
A Medicina, por sua vez, ocupa-se da doença e do organismo biológico eleito como objeto de estudo privilegiado e busca a objetividade, a constância e a regularidade no tocante aos conhecimentos e não fatos singulares que não possam ser generalizados (Chaú, 2010) ${ }^{23}$. Além disso, a ciência médica opera com uma colagem entre o signo e o sintoma (conforme foram explanados em nota de rodapé no Capítulo 1), entre o significante e significado, o que leva, inevitavelmente, à exclusão do particular.

O psicanalista sabe que a clássica equação da história natural da doença (ou do processo saúde-doença) não dá conta do padecimento do paciente, pois as necessidades humanas não são puramente biológicas, e o padecimento pode resultar das vicissitudes das complexas relações e interações que acompanham cada sujeito vida afora. Ele sabe que, diferentemente do sintoma médico ou psiquiátrico, o sintoma analítico não é objetivo, pois depende do sujeito que fala e é no movimento de falar que o sujeito vai construindo o sintoma na análise. $\mathrm{O}$ sintoma analítico é a expressão de um desejo que não visa e de antemão, ser curado, mas visa ser ouvido. (Priszkulnik, 2008, p. 3)

Posta essa diferença fundamental, podemos entender por que a Psicanálise não trabalha com o binômio norma versus transtorno, mas sim com o sintoma como manifestação do sujeito (Quinet, 2009). De acordo com a elaboração freudiana, o sintoma está a serviço da afirmação da singularidade do sujeito e possui uma função e um sentido para ele. Freud (1924-25/1996) postula que o sintoma encobre uma função de solução de compromisso entre duas forças contrárias: as exigências da civilização, ligadas ao princípio da realidade por um lado, e o desejo inconsciente, ligado ao princípio do prazer por outro. Isso quer dizer que é a partir do conflito produzido no encontro com o Outro, que impõe limites e restringe, que o sujeito constrói o seu sintoma, como substituto de uma satisfação pulsional que não pode se realizar, revelando e ocultando o conflito psíquico. O sintoma é, assim, uma resposta frente a esse mal-estar, uma espécie de negociação dos desejos com as demandas sociais, e se forma quando

as duas forças que entraram em luta encontram-se novamente no sintoma e se reconciliam, por assim dizer, através do acordo representado pelo sintoma formado. É por essa razão, também, que o sintoma é tão resistente: é apoiado por ambas as partes em luta. (Freud, 1917/1996, p. 361)

O diagnóstico médico de TDAH entende as manifestações do sujeito como uma enfermidade que deve ser eliminada por meio de intervenções medicamentosas. Reduz, com isso, a dimensão subjetiva ao corpo biológico e, ao pretender dizer tudo sobre o paciente,

\footnotetext{
${ }^{23}$ A análise dos pressupostos que configuram a clínica médica e que os diferenciam da clínica psicanalítica pode ser lida de modo mais aprofundado no precioso artigo de Priszkulnik (2000) Clínica(s): Diagnóstico e Tratamento.
} 
acaba por não dizer nada sobre o sujeito que ali se encontra. Responde à realidade velando a angústia, e esta, por sua vez, retorna como um sintoma. Toda criança passa a ser a mesma coisa a partir desse diagnóstico comum.

Diversamente, a Psicanálise, ao trabalhar com o sintoma tomando-o como expressão do funcionamento inconsciente, busca localizar, em termos freudianos: o que ocorre com a libido que não está sendo utilizada para prestar atenção no professor? O que ocorre que faz com que ela retorne ao corpo e este se torne inquieto e não responda ao chamado do outro? Por essa razão dizemos que a psicanálise não classifica, mas, antes, toma o sujeito como responsável pelo seu gozo ${ }^{24}$, pois a partir daí pode-se obter efeitos sobre a angústia. Como propõe Eric Laurent (2004), desangustiar consiste em fazer surgir a questão do desejo, o que não deixa de ser mais trabalhoso. Interessa ao analista, desse modo, entender os sentidos que podem assumir para o sujeito tal manifestação corporal desorganizada, ou ainda "extrair da modalidade de gozo que é fixada como um tipo clínico, a hiperatividade por exemplo, o caso único, em que se pode localizar a construção singular do sujeito” (Freire, 2007, p. 55).

A criança, como ser humano que é, utiliza seu corpo para expressar perturbações que a acometem, e nesse sentido o sintoma que se observa é a formação de compromisso entre as várias instâncias psíquicas, não devendo ser eliminado de modo ingênuo, mas precisando, sobretudo, ser encarado como uma manifestação singular do sujeito para expressar que algo não vai bem no plano afetivo. Quando a criança descarrega corporalmente uma agitação, podemos pensar, então, que existe ali uma angústia que não pode encontrar uma saída psíquica por meio das palavras e que extravasa corporalmente. O TDAH pode ser a forma que a criança encontrou para expressar e denunciar um mal-estar no plano afetivo, configurandose assim como um sintoma, o qual traz em si uma mensagem e um apelo dirigidos ao outro. Como bem salienta Priszkulnik (1993), “se o domínio motor está alterado isto pode ter a ver com o corpo imaginário e não necessariamente com algum comprometimento orgânico" (p. 13).

Ao encarar a manifestação da criança como um sintoma com valor de linguagem, pode-se compreender que ele se constitui como a melhor resposta do sujeito para dar conta de sua angústia, sendo, portanto, uma construção única e singular. A busca pelo sentido oculto no sintoma revela a verdade da criança, lógica esta que se opõe àquela da ciência, que tem

\footnotetext{
${ }^{24}$ O conceito lacaniano de gozo é uma construção complexa que se aproxima, de acordo com Nasio (1993) com a teoria freudiana da repetição. "Se há um conceito freudiano próximo do gozo concebido como a força que garante a repetição, é exatamente o de compulsão à repetição, entendido como a tendência irredutível, no ser humano, a viver voltado para a frente, é certo, mas tentando completar os atos esboçados no passado. Toda a força da vida está aí" (Nasio, 1993, p.43). O gozo, para Lacan, é a energia do inconsciente e não está relacionado ao prazer orgástico experimentado pelo eu. Uma das imagens principais do gozo está relacionada ao que Nasio (1993) chama de efeito "libertador e apaziguador do sintoma", pois o sujeito goza de uma satisfação com o seu sintoma que é "tanto sofrimento para o eu quanto alívio para o inconsciente" (p.25).
} 
como solução a oferta de medicamentos que visam o encobrimento e a eliminação de qualquer comportamento que fuja do esperado. Entretanto, acalmar crianças com remédios, como adverte Priszkulnik (1993), é “obturar talvez o único caminho que elas encontram de 'dizer' do mal-estar que experimentam” (p. 59). Por ser sempre um apelo ao outro, o sintoma assim silenciado por remédios acaba perdendo seu valor de pedido de ajuda e, por uma "reeducação", obriga a criança "a viver suas perturbações de algum outro modo" (Priszkulnik, 1993, p. 3), fixando tais perturbações nas mesmas significações, ainda que obrigando que elas se manifestem de outra maneira.

Para compreender melhor o olhar que a Psicanálise dedica a essa problemática, é importante situar a perspectiva teórica da qual se parte e a partir da qual se concebe a constituição do sujeito.

\subsection{Contribuições de Freud e de Lacan}

A descoberta do funcionamento do inconsciente faz com que Freud rompa com a noção narcísica de que o homem seria senhor em sua própria casa. Freud nos revela que o inconsciente se mostra presente em todas as manifestações humanas, o que traz para a cultura um novo discurso sobre o sujeito.

Para que possamos ter condição de mais adiante articular a teoria psicanalítica com a pesquisa de campo, alguns conceitos serão apresentados em seus traços essenciais através da obra de Freud, nos ensinos sucessivos de Lacan e de seus comentadores.

Iniciemos nossa apresentação fazendo referência ao conceito de inconsciente, descoberto por Freud através do caminho dos sonhos e, posteriormente, em suas formações conhecidas como atos falhos, chistes e lapsos.

\section{Inconsciente}

A concepção psicanalítica de inconsciente rompe com o cogito cartesiano da filosofia ocidental baseada na razão e na consciência. Se até então o Eu era tomado como lugar da verdade e da enunciação, Freud nos revela que este é antes o "lugar do ocultamento" (Garcia- 
Roza, 2005, p. 196). Por meio da descoberta do inconsciente, Freud nos fala que existe uma realidade psíquica marcada por fantasmas e desejos e que ela não coincide com a realidade concreta e observável. Haveria, então, um significado inconsciente nas palavras, ações e produções imaginárias de todo ser humano.

Freud conceitua o psiquismo a partir da consideração de que a maior parte dele é inconsciente e nos afeta sem que possamos nos dar conta, deslocando assim o lugar central que se acreditava era ocupado pela consciência. $\mathrm{O}$ autor concebe o inconsciente como um lugar psíquico particular, com mecanismos próprios estranhos ao ego e que não está relacionado a uma "segunda" consciência (Laplanche \& Pontalis, 2001). Seu modo de funcionamento opera segundo leis que desconhecem a contradição, a lógica temporal da razão e a negação.

Lacan (1972-73/1992a) avança ao articular esse conceito freudiano aos seus estudos sobre a linguagem, o que o leva a postular o princípio de que "o inconsciente é estruturado como uma linguagem". Lacan enuncia essa proposição a partir das categorias linguísticas de metáfora e de metonímia para explicar o funcionamento do inconsciente, o qual segue a mesma lógica da linguagem, sendo uma cadeia de significantes. A concepção lacaniana da relação do sujeito com a linguagem repousa no dado primordial de que o sujeito é constituído pela linguagem, já que somos seres falantes. Pretende com isso revelar que continuamente falamos coisas sem saber que falamos e dizemos mais do que sabemos porque somos seres atravessados pela linguagem e marcados por inscrições inconscientes que desconhecemos. A linguagem nos surpreende, pois sempre ultrapassa a intenção que tínhamos de nos expressar, se equivoca e surge inadvertidamente. Ao tentar falar sobre algo, "falo sem saber e sempre mais do que sei (além do conhecimento consciente); portanto ao falar, posso estar dando à palavra uma significação diferente daquela que realmente queria dar” (Priszkulnik, 2009, p. 18). O inconsciente seria, portanto, essa trama de "dizeres que sabe atualizar-se num 'dito' oportuno, que o sujeito diz sem saber o que está dizendo" (Nasio, 1993, p. 23).

Ora, o que Lacan e Freud vêm a revelar, portanto, é que esse sujeito até então tido como absoluto, não é "senhor nem mesmo em sua própria casa" (Freud, 1917/1996, p. 292), onde acredita estar no controle das situações. É atropelado por um outro sujeito que ele não apenas desconhece, mas que também lhe impõe uma fala muitas vezes sem sentido e repleta de lacunas. Assim, o sujeito para a psicanálise surge com uma divisão.

Tal descoberta nos fornece recursos que permitem discutir e questionar o discurso da ciência, a qual pretende dotar o homem com uma razão universal e totalizante, mas por meio da qual seria possível alcançar "A" verdade. Ao limitar-se ao conhecimento da consciência, o discurso da ciência evidencia desconhecer, ou ao menos ignorar, o fato de que não podemos 
controlar e saber tudo. A ilusão de que o ser humano saberia perfeitamente tudo aquilo que lhe ocorre é profundamente abalada pela revelação da Psicanálise. Freud desvenda assim "uma poderosa limitação às pretensões da consciência para dominar e controlar a realidade e o conhecimento" (Chauí, 2010, p. 169).

\section{Narcisismo}

Em 1914, Freud publica um artigo sobre o narcisismo caracterizando-o como um fenômeno libidinal que ocupa um espaço essencial na teoria do desenvolvimento sexual do sujeito. Trata-se de uma "atitude resultante da transposição para o eu do sujeito, dos investimentos libidinais antes feitos nos objetos do mundo externo" (Roudinesco \& Plon, 1998, p. 531). Tal acontecimento só ocorre, conforme observa Freud, num segundo momento, após o investimento libidinal dos objetos externos por uma libido do eu. Sendo assim, o autor distingue dois narcisismos: o primário e o secundário.

Inicialmente, define o narcisismo primário como um estado de difícil observação, “onde cada pulsão se satisfaz auto-eroticamente no próprio corpo" (Nasio, 1997, p. 49), uma vez que o eu ainda não se constituiu. $\mathrm{O}$ autoerotismo seria, então, o primeiro modo de satisfação da libido, que procura no corpo o prazer que cada órgão obtém de si próprio. Freud (1914a,/1996) destaca a admiração parental na constituição do narcisismo primário com o famoso aforismo "his majesty the baby", ao se referir à manifestação nos pais de seu próprio narcisismo primário abandonado, o qual projeta todos os seus ideais e sonhos a serem realizados no bebê e atribui ao filho todas as perfeições. Isso ocorre ao ponto de o adulto, ao olhar nos olhos da criança, recuperar a felicidade que acreditava ter perdido e receber desse olhar "sua própria imagem refletida às avessas ou, em outras palavras, quando olha uma criança e focaliza de fato aquela outra ideal, todo adulto consegue ver a si mesmo completo" (Lajonquière, 1997, p. 40). Voltolini (2011) menciona o quanto é paradoxal esse lugar no qual a criança é posta, uma vez que ao mesmo tempo em que, por incorporar um ideal, é servida e adorada, sofre uma intensa repressão quando não se comporta dentro do padrão adequado.

É importante sublinhar que o conceito de narcisismo e idealização pode se estender para qualquer laço, como, por exemplo, na relação professor-aluno ou médico-paciente, quando o primeiro idealiza a criança tomando-a como modelo. 
O amor dos pais pelo filho, tão tocante e, no fundo, tão infantil, não é outra coisa senão seu narcisismo renascido, que a despeito de sua metamorfose em amor de objeto, manifesta inequivocadamente sua antiga natureza. (Freud, 1914a/1996, p. 98)

Freud sustenta que o amor parental, ainda que seja objetal, traz consigo uma cota de narcisismo. Ao se endereçar a uma criança, inconscientemente o adulto demanda que lhe seja restituído aquilo que imagina ter perdido ou aquilo de que supõe estar sendo privado. Espera, portanto, encontrar a felicidade que imagina estar embutida na imagem da "criançaesperança" (Lajonquière, 1999).

Por sua vez, o narcisismo secundário corresponde ao narcisismo do eu propriamente dito. Diz respeito ao investimento libidinal da imagem do eu, sendo essa imagem constituída pelas identificações do eu com as imagens dos objetos. A criança sai do narcisismo primário quando se vê confrontada com um ideal externo que lhe é imposto e ao qual deve se comparar, o chamado ideal de eu, que apresentaremos a seguir. Ao perceber que a mãe dirigese não apenas a ela, mas também a outros e que ela não é tudo para a mãe, isso inflige uma ferida no narcisismo primário da criança. A partir daí, para se fazer amar pelo outro, a criança precisa satisfazer certas exigências. Por essa razão, considera-se que o narcisismo constitui “o primeiro esboço do que viria a se transformar no ideal de eu” (Roudinesco \& Plon, 1998, p. 532), sendo este último designado pelas representações da cultura transmitidas pelos pais.

Como coloca Nasio (1997), o elemento mais importante, que faz com que a criança saia do narcisismo primário, é o complexo de castração e o consequente "reconhecimento de uma incompletude que desperta o desejo de recuperar a perfeição narcísica” (p. 51). Em decorrência disso, o sujeito se volta para os objetos do mundo que possam vir a completá-lo, inserindo-se assim no circuito desejante que o moverá eternamente pela vida. Esta falta constitutiva e impossível de ser preenchida é necessária para a constituição psíquica do ser humano e, para que isso se realize, é necessária a intervenção da função paterna.

\section{A mediação do Ideal do eu}

A noção de um ideal do eu ${ }^{25}$ está articulada ao narcisismo e nos é fundamental para compreender esse local de engolfamento que a criança pode vir a ocupar no emaranhado das

\footnotetext{
${ }^{25} \mathrm{O}$ termo eu, provem de ich em alemão que é o mesmo que I em inglês, e o termo ego significa eu em latim. Ambos são empregados por Freud em referência a mesma instância psíquica.
} 
necessidades narcísicas dos pais. "Concebido em referência ao ideal parental sobre a criança, servirá como baliza para acompanhar o desenvolvimento do eu da criança e como fator de mensuração de seu comportamento" (Voltolini, 2011, p. 30).

O ideal do eu forma-se a partir do narcisismo infantil secundário, que se desloca do ego real para o ego ideal, dotado de todas as perfeições. A busca para recuperar a perfeição narcísica da infância ocorre sob a forma deste ideal do ego (Freud, 1914a/1996). "Enquanto instância diferenciada, o ideal do ego constitui um modelo a que o sujeito procura conformarse" (Laplanche \& Pontalis, 2001, p. 222).

É somente quando se introduz um outro que falamos em ideal de ego como uma instância diferenciada e resultante da convergência do narcisismo (idealização do ego) e da identificação com a fonte parental, com os seus substitutos e o ideal coletivo (Garcia-Roza, 2005). É assim, a partir das representações culturais e sociais tal como são transmitidas pelos pais e das críticas vindas dos demais adultos que se encarregam da educação da criança, que o ego elabora para si um ideal como um horizonte a ser atingido. Este ideal representa nada mais do que a projeção do narcisismo perdido na infância, onde o sujeito não distingue a realidade do seu ego do modelo grandioso pelo qual se concebe (Mezan, 2008). Vale observar que a "consciência moral", como uma instância observadora e crítica do ego a partir desses elevados modelos de perfeição, se faz acompanhar da formação do ego ideal.

Finalmente, o ideal de eu corresponde, em última instância, aos traços simbólicos expressos nos ideais sociais - que são introjetados e fazem a mediação por meio da qual o sujeito busca um lugar para si passível de ser amado.

O conceito de castração

Por intermédio de seu trabalho com um menino de cinco anos, popularizado como o caso do "Pequeno Hans", Freud (1908b/1996) insere o conceito de castração em sua teoria. Freud observa que o garoto, confrontado com a anatomia de sua irmãzinha, desconsidera a possibilidade de existir uma pessoa sem pênis, prevendo em seu lugar que este cresceria depois.

O complexo de castração designado por Freud está diretamente relacionado à experiência psíquica de ameaça e angústia, inconscientemente vivida pela criança frente à constatação da diferença anatômica entre os sexos (Roudinesco \& Plon, 1998). A ilusão da onipotência, na qual a criança vivia até então, exige a renúncia e o abandono de desejos e a 
aceitação dos limites do corpo que, como aponta Nasio (1997), "são mais estreitos do que os limites do desejo" (p. 13).

Quando falamos em castração, estamos nos remetendo à ideia de que não é possível gozar de sua onipotência imaginária sobre o outro. Lacan, ao avançar na teoria freudiana sobre a castração, concebe-a como o corte do vínculo imaginário e narcísico entre a mãe e o filho e que é veiculado pelo "pai”, que encarna a lei simbólica, por meio da proibição do incesto. A castração seria, portanto, um "ato de corte", resultado dessa operação simbólica à qual o sujeito é submetido (Nasio, 1997).

Convém esclarecer que o ato de castração, comumente atribuído ao pai, é, na realidade, uma operação simbólica da fala paterna que encarna a lei. O pai real também está assujeitado à lei, sendo assim, na concepção lacaniana, “o agente da castração é a efetuação, em todas as suas variações, dessa lei impessoal, estruturada como uma linguagem e completamente inconsciente" (Nasio, 1997, p. 37).

\section{Função paterna}

Lacan descreve o pai de acordo com a perspectiva freudiana, segundo a qual é sua função submeter a criança à lei da castração e permitir que ela se separe do circuito desejante e de gozo do corpo materno, ao qual estava aprisionada. Ao questionar sobre o significado do pai, Cunha (2012) afirma que Lacan concebe "que o importante é entender a sua função no complexo de Édipo, uma vez que na família o pai pode ter qualquer papel, ao passo que naquele complexo ele é a metáfora do significante materno" (p. 109). Importante destacar que a função paterna é veiculada primordialmente pela palavra materna, na aceitação da Lei.

Para Lacan (1957/1999), portanto, “a função do pai no complexo de Édipo é ser um significante que substitui o primeiro significante introduzido na simbolização, o significante materno" (p. 180). Consideramos importante destacar essa citação, pois quando falamos em pai, estamos, na verdade, sempre nos referindo a uma função simbólica, ao pai como representante da Lei, e não ao pai biológico da realidade ou a um homem na família.

Por essa razão é que Lacan se refere aos Nomes-do-pai ${ }^{26}$, no plural, para referir-se aos significantes da função paterna, ou seja, às formas de substituição do pai que estão presentes

\footnotetext{
${ }^{26}$ Lacan designou de Nome-do-pai, o pai simbólico que traz o significante da autoridade da lei e é responsável pela inscrição da ordem simbólica no inconsciente.
} 
mesmo quando a criança não possui uma figura masculina em seu núcleo familiar. Isso porque o que impõe a Lei e o limite do gozo e completude entre mãe e criança é socialmente construído e imposto pela linguagem, o que pode estar inclusive no ato de uma mãe.

É esta dimensão simbólica do pai que ao mesmo tempo limita a amplitude louca do pai imaginário e dá valor àquilo que o pai real produz, mas sobretudo é esta dimensão simbólica que permite ao sujeito um acesso parcial ao saber, um investimento no saber, saber que segunda a metáfora dita paterna limita o gozo do Outro o gozo mãe-filho. (Rassial, 2000, citado por Mrech, 2010, s/p)

\subsection{O mal-estar contemporâneo e o declínio da imago paterna}

Muito se tem escrito sobre o declínio da figura da autoridade, tradicionalmente do pai. No século passado, na época de Freud, tínhamos um modelo tradicional de escola e de sociedade pai-orientada, na qual o professor encarnava uma figura de autoridade respeitada e valorizada em seus saberes, com papéis sociais claramente definidos. Na modernidade, a rigorosa moral ocidental perdeu seu status, o pai não ocupa mais o lugar de chefe da família, as definições se multiplicaram e observamos, consequentemente, a relativização de sua autoridade $^{27}$. Diante do dinamismo irrefreável da globalização, vemos falar-se do pai ausente, do pai humilhado, do pai indiferente e "se a figura do pai declina é porque todas as formas tradicionais de autoridade estão em crise" (Gorostiza, 2007, p. 75).

Com o advento da Escola Nova e do questionamento dos valores tradicionais, a criança é colocada no centro do processo educativo e, de modo diferente, assistimos na atualidade um professor que não é mais o narrador e o representante simbólico por excelência, mas sim um agente facilitador da aprendizagem.

Em seu livro A Impostura do Mestre, Pereira (2008) afirma que a falta da figura paterna no meio familiar é relacionada, pelos professores, à desautorização que vivenciam atualmente dentro das escolas e aos inúmeros problemas gerados a partir desta realidade. De acordo com a Psicanálise, qual seria a relação entre o pai e as situações de impasse presentes hoje nas escolas? Lembremos que, conforme apontado anteriormente, o pai ao qual nos referimos diz respeito àquele que exerce a função paterna.

\footnotetext{
${ }^{27}$ R. Cláudia (comunicação pessoal, março de 2011, em disciplina na Faculdade de Educação de São Paulo no programa de pós-graduação).
} 
A partir da década de 30, Lacan, em seus primeiros anos de ensino, já falava no declínio social da imago paterna ${ }^{28}$ e num esvaziamento desta posição a partir da queda das figuras de autoridade e do estado desastroso da sociedade europeia às vésperas da guerra. $\mathrm{O}$ autor, com sua famosa capacidade de estar à escuta do social, deu-se conta de que o significante Nome-do-pai deixara de ter a operacionalidade de antigamente, devido ao desenvolvimento da ciência, do capitalismo e da democracia. Ao cair a importância do professor, do padre, do médico, Lacan percebeu que as insígnias do pai pareciam ter se enfraquecido e que a função paterna não ocupava mais a posição de outrora, o que resultaria em importantes consequências para o sujeito.

No tempo de Freud, em que existiam padrões absolutos e rígidos de comportamento, o "pai" (enquanto significante) era idealizado. Após rápidas e sucessivas transformações sociais, o pai perdeu o seu lugar e hoje podemos falar num pai degradado. As referências simbólicas que anteriormente eram menores e mais localizadas foram mundializadas pela globalização. Isso significa que foram ampliadas as possibilidades de identificação, que nas sociedades tradicionais eram facilitadas pela estabilidade representada pelas estruturas de parentesco e referendadas pela comunidade (Voltolini, 2001). Atualmente, falamos em várias funções paternas, o que se, por um lado, abre as possibilidades frente à submissão à lei imposta pelo pai traz consigo o ônus da responsabilização do sujeito por suas escolhas diante da pluralização dos Nomes-do-pai, nome este que deveria assegurar as interdições e os limites que implicam o sujeito numa filiação simbólica com o passado. Essa maior liberdade individual leva a um aumento da angústia subjetiva e produz consequências sintomáticas, já que o sujeito deve responsabilizar-se por suas escolhas na falta de uma regulação e de um apoio antes oferecido pela autoridade (Forbes, 2010). Com isso, Forbes (2012) procura afirmar que "a proliferação dos nomes do pai aumentou nossas possibilidades de escolha. Se antes o mal-estar localizava-se na impossibilidade da realização, hoje ele se manifesta na angústia da escolha. Quanto mais aumenta o risco da escolha, maior a angústia” (p. XXXI).

A educação escolar, que sempre agregou em si saberes estranhos à Pedagogia, oriundos de outros campos, viu o discurso tecnocientífico comparecer com seus saberes como legitimadores de práticas e modelos pedagógicos que buscam assegurar que tudo aquilo que

\footnotetext{
${ }^{28}$ Conceito entendido pela psicanálise como o declínio do pai encarregado de inserir a criança no campo da linguagem e de transmitir a lei da cultura, a partir da separação entre mãe e filho e da interdição e consequente renúncia da criança ao gozo de ser o objeto que completa o outro (Kupfer \& Bernardino, 2009). Importante precisar que este declínio ao qual fazemos alusão, nada tem a ver com uma eventual carência da pessoa do pai, visto que o que está em jogo é a função significante do Nome-do-pai como limite ao gozo.
} 
se passa dentro da escola saia conforme o planejado. Vemos na atualidade professores destituídos da posse do saber, não mais responsáveis pela transmissão dos conhecimentos da cultura das gerações precedentes e que não se colocam como o grande Outro representante da cultura, mas sim como um pequeno outro semelhante na sua pessoalidade ao aluno. A educação antes autoritária tornou-se permissiva e atenta só aos desejos dos alunos (Lipovetsky, 2005). Ao destituir-se da posição de representante simbólico, o enlace social entre professor e aluno danificou-se e ficou comprometido. Nesse sentido, os alunos não ocupam mais a posição de castrados e não lidam com o professor como se ele fosse o mestre. A indiferença cresce e esse fenômeno pode ser nitidamente percebido no ensino, com a perda do prestígio e da autoridade do professor.

Lipovetsky (2005) destaca que o mestre de hoje é banal, o que gera certa apatia escolar e um desafeto pelo saber. O esvaziamento das tradições públicas e a falta de engajamento com um futuro são marcas do descompromisso do homem contemporâneo com a civilização, resultado do que Hannah Arendt (1957/1997) veio a chamar de crise da autoridade e da tradição. O sujeito contemporâneo, de acordo com Lipovetsky (2005), pauta-se em viver o presente com a máxima intensidade, não mais articulado a um passado e tensionado por um futuro, devido à "perda do sentido da continuidade histórica. . . a erosão do sentimento de pertencimento às gerações anteriores" (p. 33).

Atualmente, numa sociedade que não é mais pai-orientada e verticalizada como antigamente, assistimos homens, mulheres e crianças ocuparem posições iguais e alternarem papéis. Há uma horizontalidade que condensa em si implicações importantes para a constituição do sujeito (Forbes, 2012). Numa composição inédita, imbricam-se o pai "enfraquecido", destituído de saber, com os experts em educação, que prometem soluções para qualquer desvio, visando o aluno ideal. Como resultado, assistimos atualmente pais desautorizados na educação de seus filhos, frente ao saber técnico do discurso médico e às contingências da vida moderna, abstendo-se cada vez mais de frustrar a criança. Em consonância com tal horizontalização, a modernidade, supostamente, teria se voltado de forma exclusiva para o futuro, fato que teria se consumado em detrimento de todo vínculo simbólico com o passado e a tradição.

Os objetivos em relação ao futuro se tornam imprecisos ao sujeito diante da multiplicidade de opções trazidas pela cultura. Resta uma dúvida angustiante frente à multiplicação dos Nomes-do-Pai, uma vez que não há apenas um único caminho a ser seguido e o destino do sujeito pode ser modificado ao longo da vida. O que escolher se torna pergunta essencial e angustiante para o sujeito. A ausência de um norte e de uma orientação nas 
escolhas da vida são reflexo do que Forbes $(2010,2012)$ veio a designar como uma sociedade desbussolada ${ }^{29}$. Levando-se em conta que a função do pai é estabelecer pontos de ancoragem ao sujeito, a falta de referência e de princípios norteadores comuns garantidos pelo pai faz com que os valores não se tornem constitutivos. Devido à ausência da regulação antigamente fornecida pelas tradições, as crianças não mais se organizam por valores culturais partilhados. A subjetividade pós-moderna encontra-se, assim, vazia de identidade pela falta de um modelo de autoridade (Forbes, 2012; Gorostiza, 2007).

Enfim, com base no que foi exposto e voltando à questão da relação entre o declínio da imago social paterna e os impasses pedagógicos contemporâneos enfrentados pelas crianças, entre eles o TDAH, partimos do entendimento de que esses impasses podem ser lidos como sintomas endereçados pelas crianças, pois "aí, onde o pai não acode ao chamado, o sujeito pode chegar a oferecer sacrifícios - o de si e o dos outros - como agônico e desesperado intento de fazer existir sua autoridade" (Gorostiza, 2007, p. 77). Isso significa que mesmo sob o custo provocado pelo sintoma, o sujeito manifesta por meio de seu comportamento agitado e desatento um apelo ao outro. Com seu sintoma, a criança busca responder aos encontros contemporâneos com a inconsistência do Outro e reclamar uma escuta.

A literatura psicanalítica sobre esse tema revela a importância do registro simbólico para a organização do corpo da criança. Assim, uma falha nesse momento de constituição do psiquismo, que diz respeito ao corte derivado da interdição paterna na relação mãe-bebê, acarretará possivelmente manifestações comportamentais tal como as descritas no diagnóstico médico de TDAH.

No âmbito da imagem corporal, Kupfer e Bernardino (2009) supõem que ao faltar certa estabilização psíquica proposta pelo saber da função paterna - que "oferece uma simbolização da falta, uma resposta ao real da angústia de castração e uma contenção imaginária para o corpo" (p. 51) - a criança se vê submetida ao saber médico, que nada tem a lhe oferecer sobre a sua angústia, a não ser calar e silenciar seu corpo por intermédio de medicamentos. O limite do gozo do Outro, do interdito na relação mãe-filho, é insuficiente. Assim, a decadência do saber paterno em sua dimensão simbólica produz consequências.

\footnotetext{
${ }^{29} \mathrm{O}$ homem desbussolado, sobre o qual Forbes (2010) discursa, encontra-se - devido a falta de um norte e de uma estabilização simbólica fornecidas pelo Nome-do-pai - assujeitado ao imperativo de gozo frente ao discurso do capitalismo, que "promove a redução do sujeito de desejo a consumidor" e o incita a isso que chamamos de imperativo de gozo. Mostra-se identificado ao seu sintoma, como uma modalidade altamente condensada do seu gozo, tornando-se assim "presa fácil do discurso preguiçoso da psiquiatria contemporânea que já não se esforça em captar a particularidade das estruturas clínicas, limitando-se a classificar as doenças com base em uma classificação sumária de sofrimentos".
} 
Diante disso, resta à criança responder, por exemplo, através de uma agitação motora difusa, que encena no corpo uma falha na construção de seus contornos imaginários, a falha de uma imagem corporal incapaz de conter o transbordamento da angústia.

Reconhecemos aí o quadro de TDAH, que pode ser entendido pela Psicanálise como uma reação no corpo ao declínio da imago paterna. Nessa perspectiva, os sintomas são compreendidos como uma forma de apelo pela intervenção da função paterna, devido a dificuldades no processo de constituição do sujeito capturado pelo desejo materno (Kupfer \& Bernardino, 2009). Resta à criança, conforme aponta Mrech (2010), se alienar no discurso da ciência imperante e se colar aos significantes (diagnósticos) que lhe são dados a partir da função de nomeação que a referida ciência possui atualmente e que antes era ocupada pelo pai. A identificação ao nome TDAH, propiciada pelo avanço desse discurso, nos permite

vislumbrar de que maneira a ciência passa a prevalecer como discurso na contemporaneidade, e que se constitui numa sobreposição à função paterna de algo que chamou para, ou seja, algo que se refere a uma função do desejo materno que, na medida em que impera e passa a ser desempenhada pelo social, revela uma mudança de posicionamento que aponta para o enfraquecimento do Nome-do-Pai - na contemporaneidade o discurso da ciência é quem vem a assumir esse papel de nomeação. (Mrech, 2010, s/p)

Tenderlaz (2006), psicanalista argentina, relaciona o TDAH com as operações de alienação e separação ${ }^{30}$ propostas por Lacan no seminário XI na apreensão da constituição subjetiva, ao classificar "o sujeito em sua dependência significante ao lugar do Outro" (p. 80). Para a autora, esse transtorno refere-se a uma dificuldade vivenciada pela criança no momento da operação de separação que "retorna no real do corpo na forma de uma agitação maníaca. A falha simbólica, advinda daí, dá lugar ao excesso que se revira no corpo impedindo que a criança mantenha sua atenção em algo" (Tenderlaz, 2006, p. 81).

Quando o sintoma que se sobressai refere-se à desatenção - e não à agitação - a mesma compreensão acima destacada se aplica. Nesses casos, entende-se que a criança mantém-se sob os cuidados maternos como objeto, pois ainda não efetivou a operação de separação. Permanece alienada aos significantes advindos do campo do Outro. Para que o campo simbólico da criança se constitua, é necessário que o Outro lhe empreste seus significantes. Uma falha simbólica constituída a partir daí deixa a criança aprisionada no significante do campo do Outro primordial, encarnado na mãe, conservando-se no lugar de objeto. Por esta razão, Tenderlaz (2006) considera que, "por se tratar de um conjunto de

\footnotetext{
${ }^{30}$ Alienação e separação são as duas operações de causação do sujeito. A alienação instaura a divisão originária e fornece a base para a inscrição do sujeito no simbólico (Lacan, 1964).
} 
manifestações sintomáticas que convoca o olhar atento do Outro, a criança se mantém na posição de objeto de seus cuidados, conservando ao máximo o laço fálico” (p. 81).

Nominé (1997) faz uma interessante apreciação sobre as crianças ditas hipercinéticas que não se fixam em lugar nenhum. Para o autor, essas crianças convocam os outros a cuidarem delas por conta de suas dificuldades e permanecem assim essencialmente assujeitadas ao Outro.

Logicamente existem crianças com dificuldades de atenção, impulsivas e agitadas, mas será necessário, clinicamente, compilar tais manifestações sob o nome de TDAH, termo incapaz de designar um sujeito? Há um mal real que, de acordo com Stiglitz (2006), podemos pensar de acordo com os termos de laço e não laço com o Outro - sendo a desatenção um não laço com a palavra do Outro - ou em termos de um excesso pulsional - sendo a hiperatividade e a impulsividade manifestações de um corpo que não está regulado pelo simbólico. Porém, não existem elementos consistentes que justifiquem a criação da classe dos TDAH, a qual nada nos diz acerca da relação da criança com a aprendizagem, de sua constituição subjetiva, e para isso há que se fazer distinção entre o mal real e sua construção social. Entretanto, assistimos, reiteradamente, as escolas responderem às manifestações da criança com alguns automatismos e certezas evidenciados pela apelação a laudos diagnósticos preestabelecidos que desencadeiam o uso de remédios (Zelmanovich, 2014). A prescrição de um medicamento para tratar de um mal-estar que acomete a criança toma o orgânico como causa, encerra e silencia qualquer pergunta pela verdade que o sintoma pode encarar, provocando ressonâncias determinantes na relação do sujeito com o seu sofrimento. De acordo com Birman (1999), essa sedação indiscriminada da angústia humana por meio dos psicofármacos representa um marco da atualidade e merece atenção especial, pois não implica o sujeito em sua problemática.

Cabe ressaltar que não estamos nos posicionando contra o uso de medicamentos, que por vezes possuem efeitos benéficos, mas sim pelo uso cauteloso deles, já que entendemos que "a medicação desresponsabiliza" (Tallis, 2006, p. 35), pois, se não há sujeito, não há quem possa se responsabilizar e formular perguntas a respeito daquilo que se passa consigo mesmo. Como dito anteriormente na introdução deste trabalho, quando tomamos a Psicanálise como referencial teórico buscamos incomodar, balançar certezas e "devolver ao sintoma sua dignidade", torná-lo “digno oponente", segundo as palavras do próprio Freud falando a respeito dos sintomas neuróticos (1914b/1996). A ética da Psicanálise está ancorada, sobretudo, na implicação do sujeito, e é essa a maior contribuição que a Psicanálise pode oferecer quando se propõe a pensar sobre o TDAH. 
3.4 O discurso do capitalista e o mercado de saber: mudanças na educação

Lacan apresenta o esquema dos quatro discursos pela primeira vez no Seminário 17, intitulado O Avesso da Psicanálise, que ocorreu entre 1969 e 1970 (Lacan, 1969-70/1992). A teoria dos discursos, considerada um dos instrumentos mais ativos para a Psicanálise, representa as diferentes modalidades de laço social ${ }^{31}$ e a posição a partir da qual o sujeito fala em cada uma delas. Baseado nos conceitos de pulsão e de linguagem, Lacan propôs nesse seminário que o mal-estar freudiano - estabelecido pelo conflito das relações ambivalentes do sujeito frente ao processo civilizatório, que lhe impõe uma renúncia pulsional em prol de sua própria existência (do sujeito) - é justamente o mal-estar dos laços sociais de discurso. O enquadramento da pulsão pela linguagem, decorrente do processo civilizatório, abre as possibilidades para que as relações humanas sejam estabelecidas. Logo, o que Lacan propôs, segundo Quinet (2009), é que os laços sociais são, na realidade, formas de "aparelhamento" do gozo pela linguagem.

Os quatro lugares ocupados pelo agente do discurso foram nomeados a partir de sua posição discursiva, sendo eles: discurso do mestre, discurso da universidade, discurso do analista e discurso da histérica. Tomando como ponto de partida o discurso do mestre, Lacan escreve os demais discursos numa operação de quarto de giro de um matema que resulta numa nova fórmula. Não iremos aqui discorrer a respeito da fórmula de cada um dos discursos, tampouco dos lugares e dos elementos que os compõem, formalização esta que pode ser encontrada no Seminário 17 (Lacan, 1969-70/1992). No entanto, vale mencionar que esses quatro discursos referem-se às quatro formas por meio das quais as pessoas se relacionam entre si: governar, educar, psicanalisar e fazer desejar.

Governar corresponde ao discurso do mestre/senhor, em que o poder domina; educar constitui o discurso universitário, dominado pelo saber; analisar corresponde ao laço social inventado no inicio do século XX por Freud, em que o analista se apaga como sujeito por ser apenas causa libidinal do processo analítico, e fazer desejar é o discurso da histérica dominado pelo sujeito da interrogação. (Quinet, 2009, p. 17)

Apesar de falar apenas em quatro posições discursivas, mais tarde, em 1972, Lacan veio a definir o discurso do capitalista como uma subversão, uma nova modalidade do discurso do mestre, que corresponderia às construções do mundo capitalista moderno frente às

\footnotetext{
${ }^{31}$ Laço social é aquilo que permite ao sujeito fazer vínculo com a sociedade, com a cultura. É consequência do processo de constituição do sujeito que passa pela exclusão de parte do gozo (Petri, 2000).
} 
pressões exercidas pelo empuxo ao consumo e ao gozo. Do mesmo modo que Freud preocupou-se em pensar sobre o mal-estar na civilização, Lacan atentou para o modo como este mal-estar se manifesta na modernidade como efeito do discurso do capitalista, laço social dominante em nossa época. O sofrimento manifesto atualmente, segundo Freire (2007), está relacionado à busca pelo prazer e o evitamento da dor, características do sujeito hedonista, que traz em si "a marca do imediatismo, com sede de experiências emocionais que viriam camuflar um profundo sentimento de vazio" (p. 84). A sociedade atual encontra-se, assim, cada vez mais pautada exclusivamente pelo presente e ávida pelas últimas novidades do mercado, tão propagadas pelo discurso social em uma cultura individualista como a nossa, que apregoa o prazer acima de tudo (e de todos).

A cultura, tendo se tornado um comércio, faz com que os saberes também virem mercadoria produzida pelo capitalismo. A oferta de objetos que viriam suturar a falta é apresentada num continuum desenfreado, oferecendo a ilusão de que o sujeito pode alcançar satisfação completa. Os seres humanos cercam-se, então, cada vez mais, de objetos (celulares, computadores, carros) e não de outros seres humanos, e por esse motivo, temos que a característica principal do discurso do capitalista é o fato de ele não promover o laço social, já que o sujeito passa a se relacionar diretamente com os objetos-mercadoria oferecidos pelo capitalismo (mercado), com a finalidade de gozar sem perdas (Mrech, 2010). Consequentemente, prevalece o imperativo do consumismo, no qual os objetos são buscados no real e não no simbólico, para dar conta da falta. Somado a isso, a falta de valores morais faz com que o sujeito acredite que pode tudo. Ninguém o protege de suas pulsões e nada o detém frente ao desejo de gozar. Esta desregulação pulsional e a satisfação sem limites, sempre na iminência de ocorrer, são resultados da sociedade de excessos na qual vivemos, marcada pelos valores da lógica capitalista de mercado.

A esse respeito, Freire (2007) comenta que "a eficácia reguladora da função paterna é menos garantida hoje, quando o empuxo ao gozo com o objeto da pulsão é intensamente promovido pela cultura do consumo" (p. 63). Na vigência desse discurso, portanto, o que é visado é o sucesso individual engendrado pela quantidade de ter os objetos-mercadoria, que são envoltos de uma falsa completude, mascarando a castração do sujeito (a incompletude inerente ao ser humano).

O discurso do capitalista imperante na atualidade e sustentado pelos modelos classificatórios da tecnociência que dominam a sociedade ajuda-nos a compreender algumas questões trazidas ao longo deste trabalho e que têm a ver justamente com a tentativa insistente do discurso da ciência em oferecer respostas prontas para qualquer ocorrência do sujeito, de 
modo a tamponar o sujeito do desejo e negar a castração. $\mathrm{O}$ discurso da ciência responde à demanda de gozo por meio da oferta de soluções que trazem em si a mensagem de que o sujeito não tem implicação em seu sintoma.

A psiquiatria atual, pretendendo-se científica, vai encontrar seu sentido no discurso do capitalista, ela propicia uma ilusão de controle do próprio sujeito sobre seu mal-estar a partir de paliativos químicos produzidos pelo saber científico unido aos interesses da indústria farmacêutica. (Infante, 2011, p. 68)

Atualmente, conforme discutido, o professor não é mais o representante simbólico supremo, detentor do saber, a quem os alunos devem se submeter. Uma maior liberdade individual, na qual a diferença simbólica é escamoteada e que num rápido olhar pode parecer atraente e favorável, possui consequências importantes, como já assinalado. Nesse cenário, onde a hierarquia não mais é imperante e o enlace não está mais dado a priori, assistimos a um esvaziamento do simbólico. $\mathrm{O}$ sujeito não se subordina às regras culturais e não possui valores interiorizados, resultado do pai degradado da modernidade. Esse vazio de identidade busca ser preenchido pelas ofertas infindáveis de objetos de consumo, marca característica do discurso do capitalista.

Acontece que educar passa necessariamente por transmitir um conhecimento via laço social, o que exige renúncias e interditos que o sujeito nem sempre, para não dizer dificilmente, consente em receber.

Majoritariamente, o laço social observado nas escolas é aquele em que o aluno está situado no lugar de objeto e do lado do professor está o saber universal sobre o outro. Estão identificados com a posição de quem sabe sobre o outro e não numa posição de querer saber. Como consequência, a não correspondência ao ideal de aluno justificaria para muitos professores, por exemplo, a postura de encaminhar um aluno para o neurologista com suspeita de TDAH.

Nesse discurso que marca a contemporaneidade, o saber objetivado aparece como mais um gadget (termo usado por Lacan para se referir aos objetos de consumo curto e rápido que engendram necessidades no lugar de desejos) forjado pela ciência e buscado de modo desenfreado pelo sujeito, na certeza de que sua posse trará satisfação. Os especialistas, para os quais as crianças são frequentemente encaminhadas com suspeita de TDAH, garantiriam que o processo de escolarização transcorresse sem entraves. Tentar-se-ia evitar o que é inerente às vicissitudes da educação - caracterizada por um constante processo de vir a ser -, desconsiderando aquilo que é próprio do ato educativo e que diz respeito à imprevisibilidade, a tudo o que ocorre na relação com a alteridade e que não pode ser controlado. 
Entretanto, o fato de que o sujeito escapa ao controle da educação é não apenas mascarado, mas negado, com a busca de respostas prontas em livros, manuais ou com os próprios especialistas, o que acaba por afastar o professor da criança e dificultar que ele a perceba em sua singularidade. Por esse motivo, dizemos que o discurso do capitalista é segregador e não regulador dos laços sociais.

Marcados pelo discurso do capitalista, muitos professores se cercam do saber de profissionais de outros campos (ou o que é ainda mais comum, eles próprios buscam em cursos de Psicopedagogia saberes que lhes fornecem a ilusão de que é possível controlar e dominar tudo), na busca de que tudo saia conforme o esperado. O que escapa ao controle e mostra o limite da prática educativa é negado por muitos professores que "procuram se afastar para ficar com o 'ideal' da Educação: o modelo ideal, o professor como ideal, a escola como ideal, a Educação como ideal" (Mrech, 2005, p. 29). A ilusão pedagógica à qual estão submetidos demonstra a esperança de constituir crianças ideais idênticas ao enunciado pedagógico. Entretanto, a impotência dessa ilusão retorna sob as mais diversas formas, configuradas nas tão divulgadas dificuldades escolares. Importante lembrar que nunca tivemos tantos saberes adultos sobre as crianças e ao mesmo tempo tantas famílias e professores sem saber o que fazer a respeito delas.

$\mathrm{O}$ interesse da ciência ${ }^{32}$ é colocado em evidência através do discurso do capitalista, que nos mostra esse esforço em querer dominar e controlar tudo, o que pela Psicanálise já sabemos ser estruturalmente impossível. A ciência em nossa sociedade tem comparecido mais em sua dimensão aplicativa do que em sua dimensão investigativa. Ao falar da castração, como dito anteriormente, Freud forjou um conceito fundamental para nomear aquilo que escapa, a impossibilidade de ter tudo, a falta essencial e constitutiva do ser humano. Essa corrente de pensamento vai na direção oposta àquela praticada frequentemente no interior das escolas, por meio de sequências didáticas planejadas, controles sobre o comportamento dos alunos, campanhas para evitar bullying, programas, testes e avaliações para identificação precoce de dislexia e TDAH, entre tantas outras práticas.

Vemos assim de que modo o discurso tecnocientífico comparece nas escolas em diversas vertentes, numa tentativa incessante de dar conta de tudo. Pais e alunos tornam-se

\footnotetext{
${ }^{32}$ Concebemos ser valioso precisar que as concepções de ciência, ou ideais de cientificidade, alteraram-se ao longo da história. Passamos de uma concepção racionalista e empirista para uma concepção construtivista, como bem discute a filósofa Marilena Chaú (2010). Chauí (2010) contribui, dizendo que uma das grandes diferenças da ciência antiga para a atual, está na valorização da técnica, o que reforçou e legitimou a crença no poder da ciência. Os avanços tecnológicos do século passado, e sobretudo deste século, deram origem a uma doutrina que vê como única fonte correta de conhecimento a razão.
} 
consumidores de uma educação à qual é conferida o status de mercadoria. O saber da escola e o saber dos especialistas que ali comparecem com seus laudos entram com o valor de troca, característica deste mesmo discurso. O declínio do simbólico surge nesses saberes que vêm de fora como pacotes prontos e são adquiridos por professores que não se questionam a respeito dessa lógica. A autoridade que se esboça é, portanto, "a do saber especializado e as práticas de avaliação e questionários invocam este tipo de autoridade da expertise" (Gorostiza, 2007, p. 77).

Conforme acompanhamos no capítulo anterior, os estudos de Ariès (1978) e de autores brasileiros e estrangeiros contribuíram para desmistificar um conceito único de criança, chamando a atenção para o fato de que existem "crianças" e não "A-Criança", justamente pelos aspectos sociais, culturais, econômicos e políticos que envolvem essa fase da vida do ser humano. Lajonquière (2010), ao desenvolver uma análise sobre a infância, apontou que o final do século XX testemunhou o surgimento do que ele veio a chamar de "um fantasma singular, A-criança”, naturalizado pelo discurso médico-psico-pedagógico (p. 21).

Ocorre que, atualmente, os saberes coletivizados falam sobre $A$-Criança genérica, uma abstração que já propõe um afastamento entre o professor e cada criança de "carne e osso", colocando em seu lugar uma generalização que visa apagar as diferenças (Lajonquière, 2010, p. 19). O discurso do capitalista nas escolas comparece em tais pretensões universalizantes, que ditariam o modo correto do professor agir em cada ocasião com crianças que apresentam determinados comportamentos considerados fora do padrão. Mas isso acaba por afastá-los da criança real que está diante deles e que resiste ao ideal. Este saber genérico e anônimo que comparece no saber dos especialistas e é facilmente incorporado à prática pedagógica dos professores. Diz respeito a um saber vazio e sem sujeito, já que $A$-Criança não equivale à criança singular que o professor tem à sua frente. A pretensa eficácia pedagógica endossada por esses saberes implicam, assim, no "desaparecimento da distância entre um aluno real e a criança ideal” (Lajonquière, 199, p. 93), na tentativa de apagar essa diferença factual e instaurar uma equivalência em seu lugar.

Tratar-se-ia, então, de uma relação não mais entre sujeitos, mas, antes, entre um saber sobre um objeto, marca elementar do discurso do capitalista, que não faz laço social. Nesse sentido, A-Criança seria mais um entre tantos outros objetos que o sujeito poderia apreender, e aquilo que nela escapa ao controle "tende a ser apagado, ou reinterpretado dentro da estratégia montada" (Voltolini, 2008, s/p). Podemos pensar, como exemplo do modo como isso está armado, quando vemos diversos diagnósticos dados a uma mesma criança numa tentativa incessante de dar conta de qualquer sintoma fora do esperado. Assim, não raramente, 
quadros de TDAH incluem em si diversas comorbidades, como depressão, transtorno bipolar, síndrome das pernas inquietas, dentre outros.

Os especialistas creem saber, graças a elucubrações científicas de ocasião, sobre as necessidades e interesses "da criança" ou de uma criança genérica. Em nome desse saber genérico, falam de A-criança a outros, ao Outro. Quando dirigem a palavra a uma criança o fazem inevitavelmente em nome desse saber sem nome próprio, o saber dA-Criança. Portanto, os especialistas não falam com uma criança singular com nome e sobrenome. $\mathrm{O}$ "falar com uma criança" está em função de reconhecimento, por parte do velho, da própria implicação subjetiva em uma educação, quer dizer, de como é perlaborado aquele estrangeiro ao "si mesmo adulto" que o (des)encontro com o pequeno ser realimenta. (Lajonquière, 2010, p. 215)

Ao defender um olhar individualizado e práticas educativas democráticas, vemos que as escolas, na realidade, partem da concepção de um aluno-objeto virtual tomado como ideal pelo discurso científico e expresso nos saberes (psico)pedagógicos ${ }^{33}$ hegemônicos dos especialistas, para os quais comumente as crianças-sujeito são encaminhadas com suspeita de TDAH. Ao defender a concessão de um espaço para falar sobre a criança, o que fica escamoteado nas escolas é que não se fala mais com a criança, tomando-a como sujeito e escutando o que ela tem a dizer sobre si, mas, antes, erige-se um conhecimento por cima dela, a despeito dela.

Muitos professores se dirigem às crianças a partir deste lugar de saber sobre o outro e, com isso, reproduzem práticas que discriminam e ocultam o sujeito, ao englobar manifestações singulares de sofrimento sob um mesmo rótulo descritivo, anunciado pela ciência como TDAH. Rotulações diagnósticas como esta, suplantam a singularidade da criança, tornando-a suporte corporal da voz alheia e atravessando o sujeito dentro da escola (Guarido, 2007).

Neste mesmo cenário, ainda encontram-se os medicamentos, consumidos como objetos que viriam acabar com o sofrimento. A banalização do diagnóstico de TDAH leva ao uso abusivo desses remédios, ao encarar qualquer mal-estar como uma doença que deva ser tratada. Não é à toa que Freud, já advertido sobre esse risco, provavelmente num tom premonitório do que viria a ocorrer no próximo século, fez a seguinte colocação:

O serviço prestado pelos veículos intoxicantes na luta pela felicidade e no afastamento da desgraça é tão altamente apreciado como um benefício, que tanto indivíduos quanto povos lhes concederam um lugar permanente na economia de sua libido. Devemos a tais veículos

\footnotetext{
${ }^{33}$ Termo cunhado por Leandro de Lajonquiére em seu livro, resultado da tese de livre-docência, "Infância e Ilusão (Psico)Pedagógica: escritos de psicanálise e educação", ao analisar as ilusões que comparecem no campo educativo, na medida em que pretende refletir sobre a conexão entre Psicanálise e Educação. O autor realiza uma crítica a noção de infância idealizada e às teorias e práticas criadas a partir desta para justificar os impasses escolares e eximir os professores da responsabilidade por sua prática educativa.
} 
não só a produção imediata do prazer, mas também um grau altamente desejado de independência do mundo externo, pois sabe-se que, com o auxílio desse "amortecedor de preocupações", é possível, em qualquer ocasião, afastar-se da pressão da realidade e encontrar refúgio num mundo próprio, com melhores condições de sensibilidade. (Freud, 1930/1996, p. 86)

Importante precisar aqui - ainda pensando nas consequências do discurso da ciência tomado pelo discurso do capitalista - que "o significante-mestre capital é quem comanda o saber científico: é ele quem financia as pesquisas, patrocina pesquisadores, induz a elaboração do saber, obrigando este a dobrar-se à 'política dos resultados"” (Quinet, 2009, s/p). Logo, o saber científico subsumido pela tecnologia é obrigado a produzir objetos, que na psiquiatria são os medicamentos, e que, como vimos, são transformados em objetos de consumo. Portanto, como adverte Quinet (2009), todo o investimento financeiro comandado pelas indústrias farmacêuticas em pesquisas em psiquiatria estaria subordinado aos interesses do mercado, ocultando uma intenção perversa, na qual o objetivo final não seria mais criar novos remédios para novos males, mas, antes, novos males para os remédios desenvolvidos ${ }^{34}$. Em suas palavras: "Em vez de termos drogas cada vez mais eficazes para combater novos males decorrentes da transformação da sociedade, será que não são os 'males' que agora são criados e categorizados em novas síndromes para serem então tratados pelas novas drogas?" (Quinet, 2009, p. 22).

Isso explicaria, por exemplo, o número cada vez maior de diagnósticos derivados da constante mutação da nosografia psiquiátrica e incluídos às edições do DSM e CID (Classificação Internacional de Doenças). A lógica epistêmica desses manuais diagnósticos, com sua tendência nominalista, age em perfeita consonância com o progresso da indústria farmacológica (Forbes, 2010). Vemos surgir novas categorias diagnósticas, que viriam a justificar a utilização de medicamentos por mais e mais pessoas. Numa evolução que acompanha o desenvolvimento da ciência, vemos que "o 'invólucro formal do sintoma' varia segundo a época: a histeria muda de cara, a psicose de vestes, a obsessão de ideias" (Quinet, 2009, p. 10). Como refutar a hipótese de que quanto mais subdividida for a classificação dos

\footnotetext{
34 “No Brasil”, de acordo com Escudeiro, "grupos de pesquisa e de esclarecimento à população (sobre o TDAH) são financiados pelas indústrias farmacêuticas que fabricam os medicamentos indicados no tratamento... As empresas que comercializam os medicamentos Concerta, Straterra, Ritalina e Dexedrina, todos largamente usados no lucrativo mercado do TDAH, financiam as pesquisas clínicas de associações que afirmam seguir, dentre os valores que norteiam seus programas, a ética na pesquisa e universalização dos conhecimentos" (Escudeiro 2007 citado por Kupfer, 2011, p.144).

Apesar de não caber aqui entrar na discussão da indústria farmacêutica, acreditamos ser preciso advertir o público sobre os laços fincanceiros existentes entre os autores do DSM e a mesma. Para isso citamos as pesquisas de Itaborahy \& Ortega (2013) O metilfenidato no Brasil: uma década de publicações e A Ritalina no Brasil: produções discursos e práticas. $\mathrm{O}$ uso da ritalina é considerado um dos fenômenos farmacêuticos mais extraordinários de nosso tempo, o que justifica tal ponderação crítica (Stiglitz, 2006).
} 
problemas passíveis de serem tratados por fármacos melhor para aqueles que obtêm ganhos econômicos com essa conduta médica.

A ligeireza (e imprecisão) com que as pessoas são transformadas em anormais é diretamente proporcional à velocidade com que a psicofarmacologia e a psiquiatria contemporânea expandiram seu mercado. Não deixa de ser surpreendente que o que foi apresentado como avanço na capacidade de curar tenha levado a ampliar um uma progressão geométrica a quantidade de doentes mentais. (Jerusalinsky \& Fendrik, 2011, p. 6)

Esta lógica é tão surpreendente que a quinta edição do DSM, lançada em 2013, possui 900 páginas - comparadas às 150 da primeira edição - e nela estão incluídos transtornos que nos soam bastante curiosos, para não dizer absurdos, como o Internet Gaming Disorder, que poderia ser traduzido por uma espécie de distúrbio caracterizado por pessoas viciadas em jogar jogos na internet. Por mais que, de fato, existam sujeitos que passem horas em frente ao computador jogando, o que um diagnóstico como esse poderia realmente nos revelar?

Outro transtorno recentemente incluído é o chamado "transtorno disruptivo de desregulação do humor", dado a crianças e jovens que apresentem ao longo de um ano, e ao menos três vezes por semana, sintomas de irritabilidade persistente. Não precisamos ir longe para ver crianças com ataques de birra e adolescentes contestadores serem diagnosticados e medicados em virtude desse transtorno.

O que fica evidente, portanto, nos manuais do DSM é "uma clara tendência nominalista que trata o sintoma pela via de nomeá-lo e estandardizá-lo, ao mesmo tempo em que lhe designa um objeto de consumo, por meio do qual se produz a medicalização do sofrimento" (Barton, 2007, p. 128).

Outra decorrência ainda da insistência do discurso do capitalista nas escolas, enunciado pelo discurso psiquiátrico, diz respeito à desautorização e à renúncia que assistimos frequentemente dos professores em relação ao ato educativo. Os professores, como aponta Guarido (2007), deixam de agir em nome próprio, pois desconfiam de sua competência para educar e ensinar, para dar voz aos especialistas com suas proposições universalizantes sobre o sujeito. Respondem ao discurso da ciência quando creem e não contestam, duvidam ou se interrogam a respeito desse saber imposto como verdade inquestionável. Ao acreditar que o discurso da ciência detém o saber preciso que irá dar conta do mal-estar na educação, desinvestem-se de seus saberes, esvaziam-se de sua criatividade e inventividade frente às dificuldades inerentes ao processo educativo em nome de um saber homogeneizado e genérico dos especialistas. Assistimos professores capturados e paralisados frente aos sintomas dos alunos e respondendo a isso através da responsabilização da criança 
por suas dificuldades. O resultado disso é o alarmante número de crianças sendo encaminhadas a especialistas e diagnosticadas com TDAH. Em relação à criatividade, a nossa pesquisa de campo mostrará algo diferente.

3.5 O terceiro ensino de Lacan: mais-a-se-pensar

A importância do terceiro ensino de Lacan em relação às contribuições para refletir sobre o TDAH como marca representante dos impasses pedagógicos contemporâneos nos leva a percorrer um caminho belissimamente traçado por Mrech (2005), ao discorrer sobre as decorrências desse ensino de Lacan nas articulações entre Psicanálise e Educação ${ }^{35}$. Mas antes disso, comentemos um pouco sobre que contemporâneo é esse ao qual nos referimos e que repercussões ele produz no mundo em que vivemos, especialmente quando falamos em Educação.

Conforme discutido anteriormente, vivemos hoje na sociedade do espetáculo, onde o simbólico caiu e o imaginário ocupa lugar de destaque. A cultura contemporânea globalizada caracteriza-se pelos vazios e não sensos que aparecem na linguagem. Sem a pressa de julgamentos prêt-à-porter, que trazem uma visão nostálgica de tempos anteriores para falar da ruína da modernidade e da moralidade rigorosa, Gilles Lipovestsky (2005), filósofo francês que discute a questão atual da cultura da modernidade, enxerga na pós-modernidade - à qual ele dá o nome de hipermodernidade - a era do vazio, na qual, com menos submissão, o imaginário transborda. "Tudo se move. Tudo muda. Tudo é fluxo. A modernidade escorreu para a pós-modernidade" (p. 64).

O excesso e o vazio, dois movimentos aparentemente antagônicos, coabitam e atravessam a subjetividade gerando novas angústias, uma vez que tudo pode ser questionado pela falta de uma moral imperativa dominante outrora ocupada pelo pai, chefe de família. $\mathrm{O}$ sujeito encontra-se desamparado num mundo onde tudo é efêmero e provisório. Segundo Lipovetsky (2005), nessa nova fase da modernidade, calcada por uma ideologia individualista

\footnotetext{
${ }^{35}$ Jacques- Alain Miller estabeleceu uma periodização na obra de Lacan, dividindo-a em três períodos de ensino. A saber: o primeiro ensino é apoiado no imaginário, momento em que Lacan (1985), baseado no estruturalismo, conjura que "O inconsciente é o discurso do Outro" (p.118). O segundo ensino privilegia o simbólico e reflete a passagem do grande Outro para o objeto a, com o consequente aforismo "O inconsciente é estruturado como a linguagem". Finalmente, o terceiro ensino privilegia o real, o gozo através da linguagem e da lingua e tudo aquilo que é da ordem do particular, revelando que "Não há relação sexual", ou seja, não é possível ler o que ocorre com o sujeito apelando para referenciais da cultura (Mrech, 2005).
} 
hedonista, as leis não mais imperam como antigamente e já não podemos nos referir ao sujeito e ao social pelas noções de disciplina e alienação. Como destaca Freire (2007), o desprestígio do Nome-do-pai promovido pelo discurso do capitalista "rebaixa o valor simbólico do ideal e promove os objetos de satisfação a máxima da civilização" (p. 78). Como consequência, a sociedade do consumo desenfreado e com ritmo acelerado impera, fazendo com que o sujeito se ligue aos objetos-mercadoria, que são trocados e descartados a todo momento.

Perguntamo-nos se as manifestações contemporâneas de desatenção, agitação e impulsividade das crianças, aparentemente cada vez mais numerosas, não poderiam ser expressões deste excesso de informações e de excitações a que essas crianças estão expostas e submetidas e que invadem o seu psiquismo, que, talvez, ainda não tenha condições de processar e organizar tudo isso que se passa ao seu redor.

Como pontua Mrech (2005), “o que a sociedade contemporânea não quer ver? O real, o inconsciente e a própria subjetividade humana" (p. 24), já que somos confrontados a todo momento com a incompletude do ideal. A ideia iluminista de que com a razão seria possível dominar, controlar e alcançar a verdade é denunciada também por Lacan, ao postular que a razão não tem possibilidade de controlar tudo. Lacan nos diz que há algo que sempre escapa, chamado de Real, um registro que não pode ser capturado como o simbólico ou o imaginário e que resiste a todos os esforços da ciência, que crê tudo poder avaliar. O real escapa da linguagem e está sendo deixado de lado sem que os sujeitos se deem conta disso. O real da Educação nos adverte de que o ensino tem efeitos indeterminados e imprevisíveis.

Em seu terceiro ensino, localizado a partir de 1974, com O Seminário 20, Lacan (1972-73/1992a) introduz alguns novos conceitos, entre eles o de falasser, para dizer que o sujeito cindido como havia postulado é antes de tudo um ser na fala, que possui um corpo e que está continuamente mudando. A partir dessa consideração, Lacan se preocupa em trabalhar com o impermanente, e o corpo adquire importância fundamental.

O sujeito é atravessado por modalidades de gozo que desconhecemos. Em seu último ensino, Lacan, comenta Mrech (2005), passa a se preocupar cada vez mais com tudo o que seja da ordem do singular, do particular (diferentemente do universal ao qual se dedicava inicialmente), o que o leva a localizar o sintoma como uma criação, uma invenção do sujeito para dar conta do Real.

O que isso tem a ver, então, com os sintomas que se apresentam frente à educação contemporânea, especialmente em relação ao TDAH? Muito, já que tudo o que ocorre com o sujeito passa pela cultura e seu corpo é apanhado pela grade cultural que o envolve. Entender tais manifestações como produto de nossa época e de formas de subjetivação próprias às 
crianças na contemporaneidade nos permite resgatar o sujeito em cena. Nesse sentido, notamos que hoje faltam palavras ao sujeito para dizer de si. A palavra não é mais importante, as imagens adquirem importância e há uma dificuldade desse sujeito de se localizar frente à linguagem.

Podemos fazer uma articulação com esse sintoma do contemporâneo quando pensamos nas crianças caracterizadas e rotuladas com TDAH, que encenam corporalmente algo que não pode ser falado, um sintoma singular e subjetivo, construído justamente ali onde não houve espaço para a palavra e onde surge o ato "hiperativo" ou "desatento". Na falta de palavras para traduzir o seu mal-estar, o sujeito reage colocando o seu corpo em cena. Essa falta de uma mediação simbólica deixa o corpo entregue ao funcionamento pulsional desorganizado, numa descarga compulsiva.

Zelmanovich (2014) refere-se a uma irrupção pulsional, que deixa o sujeito fora do discurso, distinguindo assim "as lógicas que comandam as estruturas subjetivas das crianças ‘desbordadas', expostas a suas próprias pulsões desreguladas” (p. 192) como modo de responder à demanda do Outro, encarnado na sociedade dos adultos.

$\mathrm{O}$ que se vive ultrapassa em muito aquilo que pode ser colocado em palavras, pois vivemos num mundo além do sentido. Vive-se sem saber o que se vive em grande parte das escolas. Assim, apesar de responder a algo posto no social como produção dos tempos atuais, o sujeito comparece ali com sua singularidade e é no encontro com a cultura que constrói o seu sintoma. Por isso, dizemos tratar-se, antes de tudo, de um sintoma subjetivo, ainda que este dialetize com o que seria chamado de sintoma social ${ }^{36}$ (Kupfer, 2011).

Sintomas como estes, que não fazem demanda ao outro e que comprometem o laço social, são característicos do momento atual. O sujeito encontra-se preso na esperança de que alguém responda por seu desejo e não demanda uma ação com o outro. O corpo assume importância enquanto que a palavra perde seu lugar de nomeação do sujeito. Outro sintoma típico dentro das escolas hoje está ligado ao "não querer saber", também confundido como sinal de um aluno desatento e distraído que poderia ter TDAH. O aluno encontra-se desinteressado, não quer estudar, desrespeita os professores, isenta-se de responsabilidade e quer que seus pais e a escola resolvam a sua situação.

\footnotetext{
${ }^{36}$ A noção psicanalítica de sintoma social é utilizada por alguns autores para se remeter a indissociabilidade do sujeito em relação ao âmbito social, e pode ser pensada como o "engendramento de sentidos que são tecidos socialmente, uma vez que o particular e o coletivo são partes de uma mesma trama" (Bastos, 2003, s/p). Como destaca Souza (1993): "o sintoma social não é como uma epidemia, fruto da inoculação por um grupo de indivíduos, do mesmo agente patógeno, tornando-os todos afligidos do mesmo modo pelo mesmo mal. Um sintoma social é formado por sujeitos que ocupam lugares distintos em sua estruturação. Como o sintoma particular, ele também é sustentado por uma fantasia... A pluralidade de sujeitos que compõe a sociedade se organiza em torno dessa construção, segundo a diversidade das possíveis entradas” (p.82).
} 
Frente a esse desbussolamento, uma alternativa é a responsabilização do sujeito pelo seu inconsciente, podendo assumir e bancar suas escolhas. A perspectiva da Psicanálise não exime ninguém e responde ao desbussolamento e mal-estar a partir de novos laços sociais. Para a Psicanálise, importa a história singular do sujeito, o caminho de constituição do sujeito, cujos processos são singulares. Importa o que ocorreu para que uma criança esteja tão ansiosa e por que apresenta um ou outro comportamento, o que a faz viver dentro do circuito da angústia e da ansiedade. A ética da Psicanálise busca escutar o mal-estar do sujeito na vida. Ao invés de lidar com aquilo que move a criança e a deixa tão agitada e ansiosa, no caso a criança diagnosticada com TDAH, por que se opta por medicá-la, dar-lhe um remédio que a aquiete, em vez de escutar o que ela tem a falar sobre aquilo que a acomete? Não existe uma desculpabilização, e o que a medicação e os rótulos diagnósticos tratam de fazer é justamente isso. Voltolini (2001) novamente nos ajuda quando propõe que a Psicanálise tem a missão de transformar a queixa entendida como dificuldade em um enigma, fazendo "advir ali onde há um sofrimento/gozo um espaço de questionamento, não queixoso, mas um tipo de questionamento no qual o sujeito se sinta implicado no que sofre/goza, responsabilizando-se (não se culpando) por aquilo que é da ordem do ato" (p. 110).

Retomando, Mrech (2005) se preocupa em pensar nas decorrências do terceiro ensino de Lacan para as contribuições na conexão entre Educação e Psicanálise e realiza colocações precisas. Ao afirmar que os saberes são sempre incompletos e limitados, esclarece a importância de o professor se dar conta disso no processo de transmissão e na aprendizagem singular do aluno, uma vez que aprender é sempre aprender com o outro. Daí coloca-se a importância do aspecto relacional que, de acordo com Mrech (2005), foi abandonado e não por acaso vem reclamar seus efeitos na cultura atual das mais diversas formas. O professor ocupa um lugar para os alunos e deve pensar de modo reflexivo que lugar é este que a sociedade propõe que ele ocupe, para então se descolar disso e se abrir a novas possibilidades e envolturas, podendo se ver com cada aluno "enganchando-o desejantemente naquilo que ele ensinou" (Mrech, 2005, p. 156). Não se pode levar o aluno a aprender sem o seu engajamento, sem o seu desejo, e isso não pode ser controlado. 
3.6 A ética da Psicanálise: responsabilidade subjetiva

A prevalência do slogan "prazer a qualquer preço e para todos", em evidência no campo da educação em nossa época, reflete-se em "transtornos" de aprendizagem, professores desautorizados e pais desnorteados. Ao afirmar que sempre haverá uma falta, algo que escapa, a Psicanálise se contrapõe à lógica da sociedade dita hipermoderna endossada pelos valores de uma cultura capitalista.

Numa frente oposta ao discurso do capitalista, a Psicanálise parte da premissa fundamental da impossibilidade de suturar a falta humana devido à perda inicial do objeto do desejo. Como consequência da castração, nenhum objeto seria capaz de satisfazer plenamente o sujeito, havendo, portanto, uma inevitável insatisfação e mal-estar na civilização. Ocorre que a castração e a falta fundamental são as condições humanas que instauram o desejo e movem o sujeito em direção aos objetos do mundo, em direção ao desejo de conhecer e de saber. O sujeito castrado, ao saber dos limites do próprio corpo, detém parâmetros corporais para se implicar e se responsabilizar por suas escolhas. Diante dos determinantes discursivos da nossa época, a Psicanálise denuncia, portanto, a urgência de interferir na lógica do imperativo do gozo imposto pelo discurso do capitalista: goze a qualquer custo. Frente ao “imperativo do TER, a Psicanálise propõe a ética da falta-a-ter, que se chama desejo, e a gestão, não do capital financeiro, mas do capital da libido" (Quinet, 2009).

Com seu discurso, a Psicanálise expressa um compromisso ético e político a respeito do mal-estar característico de nossa época, pois pretende permitir que o ato educativo sobrevenha à predominância e à permeabilidade do discurso da ciência no cotidiano escolar. A ética da Psicanálise é chamada para mostrar a responsabilidade dos professores na manutenção de determinadas formas de tratar e compreender os sintomas das crianças. Trata de produzir um estalo discursivo que venha a gerar uma inflexão no saber, oposta a inflagem trazida pelo discurso científico, funcionando, assim, como um "lembrete crônico do que o outro campo tende a recalcar" ${ }^{, 37}$ Entendemos, assim, em consonância com a ampla literatura que aborda a interface Psicanálise e Educação - em especial os fenômenos e sintomas presentes na educação de hoje - que a Psicanálise possui o seu valor por promover que algo possa ser deslocado,

\footnotetext{
${ }^{37}$ R. Voltolini (comunicação pessoal, 8 de novembro de 2008, no $7^{\circ}$ Colóquio do Lepsi, IP/FE-USP, São Paulo)
} 
discutido, no sentido de balançar as certezas e permitir que o sujeito possa criar novos significados para suas falas, podendo rever seus conceitos e modos de atuação.

Ao reproduzir o discurso social hegemônico vigente e encaminhar a "especialistas" alunos que apresentem comportamentos compreendidos como sinais de TDAH, muitos professores isentam-se da responsabilidade por sua prática educativa. Desautorizados de seu saber, renunciam à educação e destituem-se de sua tarefa ao atribuir este saber ao outro que, supostamente, detém as respostas sobre a educação das crianças. A isso damos o nome de instrumentalização dos laços sociais, que está relacionada a tudo o que foi discutido ao longo deste capítulo sobre o desamparo na contemporaneidade e a resposta ofertada pela ciência e avidamente acolhida pelos sujeitos para dar conta de preencher esse sentimento de vazio (Pereira, 2012).

O discurso da ciência, ao responder à demanda de gozo do sujeito, oferecendo soluções instantâneas que visam suprimir o sofrimento - encarnadas na prescrição de medicamentos - acaba por transmitir a mensagem de que tal sofrimento, sendo um acontecimento que se passa exclusivamente no corpo biológico do sujeito, pode ser tratado quimicamente. O que não se computa aí é que tal lógica nega e exime todo envolvimento do sujeito com seu sintoma, já que o foco é a doença e não o ser que sofre. Inversamente, a Psicanálise trabalha pela busca da responsabilização do sujeito frente àquilo que o faz sofrer, tendo com alvo de análise o discurso, as palavras e as falas. A Psicanálise se orienta, portanto, pela vertente de implicar o sujeito, convocando-o a se posicionar frente ao seu sofrimento e a não se colar a um significante (diagnóstico) ofertado de modo corriqueiro.

Por isso, acreditamos que a contribuição mais importante que a Psicanálise, como leitora da cultura, tem a fazer sobre o TDAH, tanto para as escolas e seus professores quanto para as crianças e suas famílias, é o fato de considerar que "por nossa posição de sujeito, sempre somos responsáveis" (Lacan, 1966/1998, p. 873). É preciso assumir a própria causalidade para encontrar uma saída inventiva que toque o sujeito frente às vicissitudes da educação e da cultura humana. Nesse sentido, Lacan afirma que a Psicanálise comparece para possibilitar que o sujeito queixoso possa se implicar por aquilo que sofre... e goza.

Tentamos analisar e enfatizar neste capítulo que responsabilizar-se por aquilo que diz respeito ao sujeito é a saída saudável que este deve encontrar para articular-se no mundo e inventar uma solução que dê conta de seu mal-estar na civilização.

Os professores devem buscar um estilo próprio de ensinar e lidar com as contingências do dia-a-dia, substituindo um ideal inatingível e impossível, ligado à imagem do aluno ideal, por um ideal subjetivado, que diz respeito à possibilidade singular 
do sujeito responder aos impasses pedagógicos contemporâneos, encontrar sua "justa medida" (Lacan, 1972-73/1992b). 


\section{PERCURSO METODOLÓGICO}

A concepção de investigação que embasa este trabalho é o modelo de pesquisa clínicoqualitativa, "considerado como uma particularização e refinamento dos métodos qualitativos genéricos" (Turato, 2010, p. 38). A opção pelo trabalho com esta pesquisa se dá pelo objetivo de compreender os fenômenos humanos e estudar o objeto específico em sua profundidade, no caso, a fala dos professores acerca dos sentimentos, atitudes e ideias sobre a criança diagnosticada com TDAH, para então buscar interpretar quais significações eles atribuem a este fenômeno. Esta proposta é garantida pela pesquisa clínico-qualitativa, uma vez que ela permite o acesso do pesquisador a questões de foro íntimo por meio de entrevistas em profundidade (Britten et al., 1995, citado por Turato, 2010). Turato concebe esta metodologia, definindo-a como:

O estudo e a construção dos limites epistemológicos de certo método qualitativo particularizado em settings da Saúde, bem como abarca a discussão sobre um conjunto de técnicas e procedimentos adequados para descrever e compreender as relações de sentidos e significados dos fenômenos humanos referidos neste campo. (p. 240)

O método clínico-qualitativo é concebido por Turato (2010) como um meio de conhecer e interpretar as significações que os indivíduos dão aos fenômenos do campo do binômio saúde-doença. Partindo-se de algumas considerações centrais, que foram apresentadas na parte inicial do trabalho, este método mostrou-se ideal devido aos pilares que o sustentam, sendo eles: valorização da angústia e ansiedade humanas, atitude clínica de acolhida do sofrimento humano por meio da escuta e atitude psicanalítica na coleta dos dados e no referencial teórico para discussão dos resultados.

O trabalho está dividido em duas partes. Primeiramente, realizou-se uma vasta pesquisa bibliográfica, com o objetivo de situar a atual discussão em torno do TDAH, discutir criticamente e contextualizar alguns conceitos que norteiam este trabalho. Em seguida, passamos para a etapa da pesquisa de campo com a entrevista de professores, na qual o referencial teórico norteador escolhido foi a Psicanálise. Por meio de uma escuta psicanalítica, atenta ao inconsciente, àquilo que não sabemos que sabemos e o falamos, às intercorrências e ao não esperado foi possível capturar a fala das entrevistadas em suas sutilezas, por meio de uma atenção flutuante. Isto foi possível graças à experiência da pesquisadora no campo da 
Psicanálise, conquistada após alguns anos de escuta, análise pessoal, formação e supervisão. Tal atitude e orientação clínica são elementos fundamentais para permitir que o sujeito fale sobre sua própria experiência de modo singular, realizando associações livres e favorecendo que ele possa vir a se responsabilizar por aquilo que fala e, possivelmente, até elaborar-se subjetivamente.

O levantamento bibliográfico permitiu-nos contextualizar o tema do TDAH a partir de diferentes vertentes, seguindo o percurso que deu origem ao chamado transtorno. A isso se seguiu uma análise crítica do que vem sendo compreendido como TDAH, discussão esta embasada por consagrados autores que têm se dedicado a estudar o assunto já há algum tempo. Apresentamos ainda, brevemente, a questão das avaliações psicológicas, já que este é um critério valioso no diagnóstico médico de TDAH. Nesta etapa, a Psicanálise nos ajuda a compreender o fenômeno a partir da noção de sintoma e de outros conceitos psicanalíticos fundamentais.

Hipóteses iniciais inevitavelmente fizeram parte do trabalho, já que partimos de uma inquietação para a escolha do tema e da pesquisa. Entretanto, é importante ressaltar que não tratamos de comprovar algo, o que teria a ver com uma pesquisa de concepção positivista, mas sim de suspeitar e deixar-nos levar pela possibilidade de nos surpreender, de descobrir e de nos deparar com o inesperado. Não abandonamos nossa suspeita, mas tratamos de dialogar com ela a todo o momento, para não cair na armadilha de uma pesquisa banal, de comprovar o que já estava dito ou de buscar nos achados dados que reafirmassem e comprovassem as hipóteses da pesquisadora. Ademais, não acreditamos, tampouco pretendemos, ter alcançado nenhuma conclusão definitiva, levando em consideração que a Psicanálise pretende "chegar a uma visão harmônica de uma parte da realidade", mas que resta sempre incompleta e sujeita a revisões (Freud 1922/1923, p. 268).

Apresentamos a seguir os elementos da pesquisa realizada.

\section{Participantes}

Foram realizadas entrevistas com nove professoras do Ensino Fundamental I de diferentes escolas particulares da cidade de São Paulo. O tamanho da amostra não foi previamente fixado por tratar-se de uma pesquisa qualitativa. Portanto, considerou-se que o 
número final só poderia ser fechado durante a fase de coleta de dados, até que as questões colocadas inicialmente tivessem sido respondidas e constatássemos que elementos novos não poderiam mais ser depreendidos. Consideramos que o corpus abrangeu dados suficientes para que pudéssemos elaborar uma compreensão do discurso das professoras sobre o TDAH. Das participantes, todas lecionavam em escolas de nível socioeconômico elevado, localizadas nas zonas oeste e sul da cidade. As entrevistadas tinham entre 26 e 50 anos de idade e de 5 a 28 anos de atuação como professoras. Os seguintes critérios de inclusão foram utilizados: ser professora polivalente (de todas as disciplinas, estando com os alunos integralmente durante o período escolar), ter ao menos cinco anos de experiência em sala de aula (para que tivessem a vivência abrangente desta atuação e com maior possibilidade de terem se deparado com crianças diagnosticadas com TDAH), ser professora de escola particular de Ensino Fundamental I (para buscar o que vem sendo feito na rede particular e por professores das séries iniciais, pois o diagnóstico surge neste momento da vida escolar da criança) e atuar em escolas selecionadas dentre as primeiras do ENEM nos últimos dois anos (este critério foi utilizado para investigar qual formação e que tipo de informações os professores de escolas particulares de nível elevado têm buscado para dar conta da questão do TDAH, tendo em vista que discussões sobre as problemáticas da escola pública, associadas às más condições de trabalho e aos baixos salários pagos, já são numerosas e repletas de autores de grande renome que a discutem com proeza. Nosso interesse situa-se, portanto, no outro polo, já que a maioria dos estudos dirigem-se para o sistema público e, partindo da hipótese de que as coisas vão mal e as críticas estão postas, o que se passa nas escolas particulares que supostamente têm em sua rede professores que podem pagar por cursos de aprimoramento? Teriam eles uma capacidade de reflexão crítica maior? O que os motiva como professores?

Para facilitar a apresentação dos resultados e preservar a confidencialidade das entrevistadas, estas serão chamadas por: Vera, Roberta, Clara, Juliana, Débora, Meri, Marta, Rose e Ângela.

\section{Procedimentos}

As entrevistas semidirigidas foram registradas com o auxílio de um gravador digital por escolha da pesquisadora e desenrolaram-se a partir de algumas questões disparadoras que serviram como instrumento auxiliar: O que você entende por TDAH? O que é para você uma 
criança desatenta/agitada? O que você pensa sobre o fato de algumas destas crianças serem medicadas? O que muda saber ou não do diagnóstico para a sua prática educativa?

Para assegurar omitir os dados pessoais das entrevistadas, fez parte do procedimento das entrevistas a explicação da pesquisa e a apresentação do Termo de Consentimento Livre Esclarecido (TCLE) de acordo com a Comissão Nacional de Ética em Pesquisa (CONEP) (ver Anexo).

O contato inicial com as participantes ocorreu por e-mail ou por telefone, com o convite para a participação na entrevista e agendamento numa data e local conveniente para elas. A escolha ocorreu por indicação e facilidade de vínculos institucionais. Os procedimentos foram realizados fora das escolas, em ambiente preservado e tranquilo, na maioria dos casos na própria casa da entrevistada, com cuidado especial para o setting e com a duração média de uma hora. As entrevistas foram transcritas integralmente, analisadas à luz da Psicanálise e posteriormente descartadas.

Durante as situações de entrevista foram levados em conta os seguintes elementos fundamentais da Psicanálise: inconsciente, escuta flutuante, associação livre, interpretação e transferência. O sujeito do inconsciente está presente em qualquer enunciado e supõe um saber que não se sabe. As questões disparadoras tomaram rumos distintos para cada entrevistada, seguindo as associações livres que foram se desenrolando ao longo da entrevista. Visamos privilegiar a fala das professoras, tentando localizar as múltiplas relações que as guiam e o modo próprio de atuação que inventam em sua prática educativa cotidiana.

Em relação à análise das entrevistas, após sucessivas leituras do material obtido, foram realizados recortes e seleção de vinhetas com a consequente eleição de categorias, que dialogam a todo o momento com a bibliografia levantada. Tal estratégia de análise se deu devido à repetição de alguns assuntos e para facilitar a apresentação dos resultados encontrados. A Psicanálise foi utilizada para a discussão das categorias apresentadas.

Finalmente, o trabalho que nos propusemos a realizar possui sua riqueza maior nas próprias entrevistas e na escuta do que cada professora teve a dizer quando confrontada com o que pensa sobre o TDAH. Não pretendemos tirar conclusões abrangentes e definitivas, mas, antes, abrir campo e espaço para que haja implicação do professor frente ao seu ato de educar, o que inclui o olhar que ele dirige às manifestações das crianças. A Psicanálise nos faz refletir sobre o que falamos e fazemos. Traz certo incômodo e força o sujeito a sair do lugar comum para se posicionar frente ao real. Apresentamos peculiaridades de determinado grupo de professores e com isso já podemos perceber o quão controversa e incômoda é a questão do 
TDAH para a classe docente, sendo preciso abordar este tema de modo a contribuir para uma reflexão e posicionamento críticos. 


\section{APRESENTAÇÃO E DISCUSSÃO DAS ENTREVISTAS}

Dificeis problemas com que se defronta o educador - como ele tem de reconhecer a individualidade constitucional da criança, de inferir, a partir de pequenos indícios, o que é que está se passando na mente imatura desta, de dar-lhe a quantidade exata de amor e, ao mesmo tempo, manter um grau eficaz de autoridade. (Freud, 1933/1996, p. 147)

Após sucessivas escutas e leituras do material gravado e transcrito, na busca de características por vezes compartilhadas entre as professoras e em muitos momentos singulares, foi-nos possível realizar algumas considerações a respeito das significações e dos significantes que marcam o lugar daquilo que estas professoras vêm entendendo como agitação, desatenção e TDAH. Para facilitar a apresentação dos achados, optamos por separálos por temas, agrupados de acordo com concordâncias e dissonâncias encontradas na fala das entrevistadas e elencadas pela pesquisadora. Utilizaremos algumas vinhetas para ilustrar a análise das entrevistas e mostrar como a Psicanálise, em sua escuta e enquanto referencial teórico, nos permite fazer com que o dito fale, recriando novas significações e propiciando, muitas vezes, uma mudança de posição frente ao dito. Importante salientar que apesar da escolha pela divisão das entrevistas em categorias de análise, os temas se cruzam a todo momento e, assim, nunca encerramos a discussão apenas dentro daquilo que seria concernente ao tema do enunciado. Circulamos a todo momento pela teoria apresentada nos capítulos teóricos, visando conferir embasamento e densidade para a nossa discussão.

No início dos encontros, foi bastante frequente a fala espontânea das professoras ao contarem um pouco sobre a formação acadêmica e o percurso profissional que seguiram. $\mathrm{O}$ Termo de Consentimento Livre Esclarecido, apresentado antes do início das entrevistas, foi recebido em todos os encontros com naturalidade e rapidamente o documento foi lido e assinado na intenção de dar logo início à entrevista. Vera e Débora o receberam com indiferença e não se preocuparam em guardar consigo o documento assinado. 
O que os professores têm buscado?

Em relação à formação de graduação, todas cursaram Faculdade de Pedagogia, sendo que Vera e Juliana também são psicólogas, embora não atuem nesta área. Dentre as nove professoras entrevistadas, seis fizeram especialização em psicopedagogia, sendo que duas delas também atendem em consultório particular. Relatos frequentes, encontrados no discurso de várias professoras, dizem respeito à busca pela psicopedagogia para dar conta de um saber sobre a criança com dificuldade de aprendizagem ou com algum outro diagnóstico. "Eu comecei a trabalhar com essas crianças e ai eu senti a necessidade de fazer a psicopedagogia pra entender um pouco melhor por que tinha muitas crianças que a gente percebia um atraso ali”, diz Débora. "A psicopedagogia te dá ferramentas para a escola, para atingir mais, $e$ você trabalha com as dificuldades especificas que cada vez a gente vê mais." "Senti necessidade de fazer a psicopedagogia pra entender um pouco melhor por que tem muitas crianças que a gente percebe um atraso”.

Quando indagada a respeito da grande procura por este curso por parte das pedagogas, Roberta responde:

Acho ótimo que façam (a psicopedagogia), porque a pedagogia é muito fraca, é muito fraca. Hoje em dia, a maior dificuldade da escola é achar bons profissionais porque agora as babás e as empregadas resolveram fazer pedagogia. (Roberta)

O olhar preconceituoso e elitista desta professora evidencia uma realidade comum atualmente e que diz respeito à constante busca por especializações, uma vez que a graduação na maioria das vezes não basta para se alcançar sucesso na carreira profissional. Como resultado, vemos cada vez mais a oferta e a demanda por cursos de aperfeiçoamento e aprimoramento, com o objetivo de circunscrever e delimitar campos de atuação e de conhecimento cada vez mais específicos, que almejam desvendar um saber sobre o ser humano, que em última instância pretende se apresentar como "O" saber portador da verdade.

Localizamos nas falas das entrevistadas uma preocupação em analisar a queixa escolar e encaminhá-la para o especialista, considerando que isso é tarefa do professor. Débora realiza o seguinte comentário a esse respeito: 
Apesar da professora não diagnosticar e não agir sem acompanhamento externo de um especialista, a gente tem que pelo menos identificar para encaminhar, né? Então eu senti uma necessidade de fazer um curso a mais e fiz a psicopedagogia. (Débora)

Observamos por meio desta fala elementos muito semelhantes àqueles encontrados na literatura médica sobre o TDAH, que mostram que se acredita ser papel do professor identificar o transtorno. Chama a nossa atenção como de fato o discurso médico está incorporado na prática desta professora, que para além do ato educativo, entende que é sua função identificar comportamentos que possam caracterizar uma desordem psiquiátrica.

Juliana, que também é psicóloga e fez psicopedagogia, nos conta que no momento está fazendo um curso de psiquiatria para estudar mais sobre o TDAH. Possui especialização em dislexia e sobre isto faz o seguinte comentário:

Comecei a me interessar por essas dificuldades. Fiz uma especialização em transtornos de aprendizagem. Comecei a pesquisar e ir atrás e eu descobri que existia a dislexia. Ai fui no Simpósio Internacional de Dislexia no Brasil e comecei a identificar um monte de coisa e aí que eu comecei a me interessar por essa [TDAH]. Agora, nesse curso [de psiquiatria] vejo todas as outras síndromes e transtornos que eu vejo é um número grande de pessoas que tem. Estou estudando o TDAH com ênfase na hiperatividade e com ênfase na desatenção. (Juliana)

Esta colocação de Juliana nos faz pensar no modo como as pessoas passaram a se reconhecer nos tratados de psiquiatria, encontrando um nome para o mal-estar que as acomete, um lugar que os situe entre os demais, talvez uma identificação ou ainda uma explicação científica para aquilo que não se enquadra e não é aceito socialmente. Esta professora considera que a sua prática educativa foi bastante influenciada por seus estudos na área da psicopedagogia e da psiquiatria:

Eu acho que a visão muda muito, porque você começa a enxergar mais o individual e ter conhecimentos de outras coisas que você não imaginava. Então, você não entende em sala de aula porque o aluno tá fazendo aquilo e agora você começa a imaginar que deve ser por causa daquilo. Você começa a entender melhor e a sua ação, a sua prática, fica com mais qualidade. Você consegue atingir os seus alunos melhor. (Juliana)

Outra questão que nos chama a atenção é a referência que duas professoras fazem entre crianças de inclusão e crianças com TDAH, colocando-as quase que em pé de igualdade e localizando aí as dificuldades que as motivaram na busca pela psicopedagogia. Essa é uma questão que merece ser destacada, pois crianças com o diagnóstico médico de TDAH estão sendo tratadas no interior das escolas, muitas vezes, como crianças de inclusão, ou seja, possuem um currículo adaptado, realizam provas em situações distintas das demais - o que 
muitas vezes é entendido como um benefício -, além de não serem reprovadas. Roberta, quando perguntada sobre o motivo da procura pelo curso, comenta:

Sempre gostei de trabalhar com inclusão, sempre me interessei pelo tema e achei que a psicopedagogia me daria embasamento em relação a isso. Então, eu fui buscar uma ferramenta para poder trabalhar também fora da escola, porque aqui eu atendo dificuldade de aprendizado. Então tem alguns Asperger, os TDAH, alguns déficit de atenção. Então, fora da escola eu atendo casos de inclusão, né? (Roberta)

Indagada pela pesquisadora sobre o termo "aluno de inclusão", Roberta oferece exemplos como Asperger, síndrome de Down, demais síndromes, dislexia e o TDAH, afirmando que sempre que há um diagnóstico trata-se de um caso de inclusão. Lembremos que a associação ao termo "inclusão" remete a um preconceito, pois desde o seu surgimento, o termo esteve vinculado à ideia de normalização, a uma forma pejorativa de se referir a crianças e adolescentes portadores de alguma deficiência física ou mental, que deveriam ser integrados ao ambiente escolar. Assim, nivelar o TDAH com a inclusão escolar trará consequências para a posição a partir da qual esta criança será falada pelo discurso pedagógico e a partir do qual construirá não apenas sua relação com o aprendizado, mas a sua própria subjetividade.

O excerto acima, além de destacar o recurso que determinada classe social possui ao psicopedagogo como um "apoio" escolar, revela algo que possivelmente não seja notado facilmente pelo leitor, tampouco por aquele que enunciou a frase. Referir-se à criança como “o Asperger”, “o disléxico”, “o hiperativo”, prática comum atualmente no interior de muitas escolas, acaba por suplantar a subjetividade do sujeito, que passa a ser reconhecido socialmente por um distúrbio ou por um traço prevalente e não mais por aquilo que lhe é singular e único.

Inserir a criança no laço social como "a TDAH” é reduzi-la ao registro médico e, como bem coloca Vorcaro (2011) ao referir-se ao que ela chama de efeito bumerangue da classificação psicopatológica da infância, "amputar sua singularidade subjetiva" (p. 228). Trata-se, como diz a autora, de casos em que o nome próprio da criança é substituído pela identidade social conferida pelos diagnósticos. Os efeitos disso na produção discursiva que antecipa os possíveis destinos para o sujeito poderia ser articulado à ideia das profecias autorrealizadoras. Deixemos isso, porém, ao leitor apenas a título de nota, a fim de se ter em mente a dimensão que uma nomeação aparentemente ingênua e desapercebida pode ter. Parafraseamos novamente Vorcaro (2011) para insistir que a "valência do déficit assume um 
estatuto imaginário tal que o sobredetermina, submetendo uma criança a avatares que constringem sua subjetivação" (p. 229).

Rose, que já trabalha há 18 anos como professora e tem um filho diagnosticado com TDAH, pretende seguir a carreira com o chamado "coaching educacional", que conforme ela explica, "é um life coach. Estabelece metas com alunos e com a família”. Isto nos leva a um outro ponto extremamente relevante para a nossa reflexão e que está relacionado às questões da escola particular de elite e à classe dominante que a frequenta. Rose é também professora particular, recurso este frequentemente buscado por alunos destas escolas para tentar suprir qualquer dificuldade em alguma disciplina. Não obstante esta saída de enfrentamento para a dificuldade de aprendizagem, agora essas crianças possuem um tutor que lhes ajudará também na organização e manejo do comportamento na escola. Fazemos um breve parênteses aqui para lembrar que os filhos das classes abastadas, desde antigamente, já possuíam a figura do tutor ou preceptor, que cuidava de aspectos relacionados à sua educação. Muda-se a roupagem e o título, mas a lógica é a mesma para a "nobreza" atual, qual seja, a existência de um terceiro mediando a relação entre pais e filhos.

De acordo com Rose, quando o aluno recebe um diagnóstico de TDAH, "ele precisa sempre de um apoio a mais, porque a escola não dá conta de dar o suporte que esse aluno precisa. Ele precisa também de um tempo maior para fazer a prova”. Entram aí o rol dos chamados "benefícios" obtidos em função de um laudo psiquiátrico dentro das escolas. Sobre isso Meri comenta que "ele tem uma prova diferenciada, a escola faz uma adaptação", enquanto Débora diz que na escola onde trabalha "a família contrata uma pessoa por fora, que fica o tempo todo com a criança na escola". "A partir do momento que vem um diagnóstico, esse aluno é avaliado de forma diferente. Ele não vai fazer uma prova. A gente faz uma prova diferente para ele”, relata Débora ao se referir às condições especiais que o aluno com TDAH possui. Nestes casos, enxergamos como tanto o aluno quanto a professora e a família são eximidos de responsabilidade. Já que a escola crê que pouco pode fazer além de oferecer essas condições especiais, a família acredita que precisa apelar para a ajuda de terceiros no processo de educação da criança, sendo que organização e disciplina de estudos deveriam partir de casa. Além disso, a criança parece ter que pouco se esforçar, já que esse exército de especialistas está a seu dispor, a fim de garantir que ela passe de ano.

Ainda que esta análise possa parecer simplista, grosso modo tais práticas engendram esse tipo de lógica, e as nefastas consequências disso para o sujeito não são sequer consideradas. Por fim, Rose ainda comenta: "Noventa por cento de meus alunos particulares são usuários de Ritalina”, um dado que vem se somar ao nosso entendimento de que a 
responsabilização por aquilo que é entendido como um impasse escolar é colocada alhures. A culpa é do cérebro... mas a criança paga com seu corpo.

Marcamos aqui um ponto importante de diferença entre a escola pública e a escola particular de elite, em relação a esse apoio em terceiros e os recursos com os quais as crianças de escolas particulares de elite podem contar. Isto revela um privilégio de determinado grupo social em relação ao próprio processo de educação e ao chamado fracasso escolar.

É espantoso o relato de Débora ao se referir à escola de elite em que trabalha:

A família vê que o filho tá indo mal na escola... Eu já vi casos onde o dinheiro rola solto. Então ela paga. Está indo mal na escola, e com os benefícios que tem o TDAH, meu filho agora é desatento. Eu já vi várias famílias fazerem isso. Aqui tá o diagnóstico, pronto agora ele não pode mais vir com nota vermelha. (Débora)

Trata-se de uma lógica perversa, mas que, como podemos ver, é suportada no interior dessas escolas de elite, que atendem a classe economicamente favorável detentora de um grande poder de decisão sobre o destino escolar de seus filhos. Ao dizer que "o dinheiro rola solto”, Débora pretende falar que com dinheiro se faz aquilo que se quer, porque dinheiro é símbolo de poder em nossa civilização.

De volta à análise sobre o interesse pela formação, Marta, por sua vez, que também já trabalha há 20 anos em sala de aula e irá se aposentar, gostaria de fazer psicopedagogia para atender em consultório, pois considera ter muita experiência com crianças com as mais variadas questões e dificuldades de aprendizagem. Entretanto, essa escolha parece estar relacionada ao desejo de continuar trabalhando com educação, ainda que não em sala de aula.

Porque sala de aula é extremamente desgastante e eu não quero perder esse pique. Quero parar antes que eu perca esse, sabe, esse tesão mesmo que eu tenho, e essa compreensão, essa paciência. Acho que tudo isso tem a ver também não só com conhecimento, mas com paciência mesmo, com conseguir olhar o outro e conseguir criar estratégias, criar atividades. Acho que isso uma hora vai se esgotar na sala de aula. (Marta)

Entendemos que essa paciência à qual Marta faz alusão talvez se refira à capacidade de aceitar o ritmo diferente do outro, aceitar que o outro possua uma forma singular de se apropriar do conhecimento e de se relacionar com os outros e se portar no mundo, que não coincide com o ideal que se tem em mente - que por ser ideal é impossível de ser alcançado.

Dentre as entrevistadas, Clara, apesar de ter realizado o curso de psicopedagogia, parece possuir uma clareza distinta das demais, pois não indica ter a ilusão de encontrar 
respostas prontas ou soluções mágicas para lidar com as dificuldades dos alunos em sala de aula. Como ela bem coloca: "Fui fazer a psicopedagogia pra entender melhor como a criança aprende”. Além deste curso de pós-graduação, Marta fez especialização em Educação Infantil e realizou diversos cursos na área de leitura e escrita. Foi a única professora a revelar que pretende estudar Psicanálise no ano seguinte:

No ano que vem vou fazer um do Sedes sobre Freud. Gosto de Psicanálise e gosto bastante de estudar. Acho que faz toda diferença... Então, busco os cursos porque gosto tanto do que eu faço, sou tão apaixonada pelo que faço, que eu quero fazer melhor sempre. Poxa, eles tão ali, o professor é tão importante. (Clara)

Chamou muito a nossa atenção diversas colocações desta professora, que serão apresentadas nas categorias a seguir, no sentido de se colocar como sujeito implicado diretamente no processo de escolarização das crianças. Clara considera que é papel fundamental do professor envolver o aluno e dar conta da agitação por meio de aulas envolventes, inventivas e interessantes.

Acho que os agitados vão ficando menos agitados. Acho importante o professor olhar o que tem e não o que falta. Não dá para ter alunos ideais nem a sala ideal. Você tem que trabalhar com essas crianças para elas crescerem. (Clara)

Essa mesma busca por alguma formação que se some à prática pedagógica - e não que a suplante, no sentido de ir além daquilo que é próprio deste campo para colar-se ao discurso médico que impera na educação - pode ser encontrada na fala de Meri. Recém-formada em letras, voltou os seus estudos para a área da linguagem e diz ter sempre se interessado por literatura infantil e português. Por achar a pedagogia muito ampla foi que resolveu se especializar na faculdade de letras. "Eu não fui fazer psicopedagogia como a maioria das pedagogas fazem. Eu não considero... Particularmente não concordo com este curso de psicopedagogia." Neste caso, vemos que, apesar de o avassalador discurso médico tecnocientífico comparecer atualmente dentro das escolas, encontramos ainda notáveis casos de resistência e de oposição como este, frente à esmagadora e incessante medicalização das questões escolares.

As entrevistas revelam que muitas das professoras apontam o interesse em conhecer a criança sob todos os ângulos como responsável pela opção pela psicopedagogia, numa busca de otimizar a prática educativa. Vimos nos capítulos anteriores o processo por meio do qual a infância tornou-se objeto do discurso médico-científico que ultrapassou a família e a escola 
nos cuidados dispensados à criança. A pretensão da modernidade, que toma a criança como aposta do futuro, faz com que o interesse em cuidar dela e evitar qualquer intercorrência que possa colocar em risco este ideal torne-se justificada. Os conhecimentos buscados sugerem uma preocupação em evitar justamente aquilo que é inerente à vida de qualquer criança, que constitui a crônica de sua vida e que designa um lugar singular a partir do qual ela irá se posicionar frente ao mundo.

O ideal de criança que repousa, latente ou explicitamente, no imaginário destas professoras reforça e é reforçado pelo ideal que elas têm para si próprias, pois a idealização é inerente a todo ser humano. Há o desejo e a ilusão de que quanto maior o saber mais será possível ordenar, normalizar, corrigir a situação e evitar tudo aquilo que é indesejado durante o processo de escolarização de uma criança. O que é buscado frequentemente em cursos de atualização, de psiquiatria e, em especial, de psicopedagogia, diz respeito ao interesse em descobrir o modo de controlar o comportamento e garantir o aprendizado dos alunos, como se houvesse uma fórmula mágica que pudesse ser ensinada.

Temos um exemplo disso na fala de Débora, quando ela menciona "os especialistas que vão nos orientar para o que deve ser feito". Porém, advertidos pela Psicanálise, estamos informados sobre a impossibilidade estrutural de evitar que ocorram descontinuidades e intercorrências neste processo. As vicissitudes da aprendizagem são particulares e não há técnica alguma capaz de controlar tal processo. Caracterizada por Freud como profissão impossível, a educação, ao investir na transmissão de uma lei e de um saber herdado das gerações precedentes, inevitavelmente irá fracassar na tentativa de alcançar um ideal. Cada sujeito se conduz em uma direção por ele mesmo determinada e que sempre estará além ou aquém do previsto.

\section{O que é uma criança agitada?}

Agitada? É uma criança inquieta, que não para muito sentada, precisa sempre se colocar, $e$ às vezes ela se atropela um pouquinho na hora de esperar sua vez. É uma criança que está o tempo todo precisando de coisas para fazer. (Rose)

As professoras entrevistadas foram unânimes em admitir que a agitação da criança diz respeito a uma inquietação. Seis professoras associam a agitação corporal a uma questão motora, na qual a criança precisa estar sempre em movimento e fazendo algo. 
Uma criança muito agitada é aquela que não consegue se concentrar naquilo que ela tá fazendo, corporalmente, e às vezes também emocionalmente, né? (Clara)

Uma criança agitada não para quieta num lugar, está toda hora levantando. Tem sempre um motivo para levantar. Eles estão querendo sempre fazer alguma coisa. Termina uma atividade e querem saber o que é depois, têm uma ansiedade. (Vera)

São apontadas atitudes descritas como descontrole e impulsividade. Notamos nos excertos abaixo inúmeras menções a desorganização do material, excesso de fala e dificuldade em escutar o outro.

É uma criança que tem uma certa dificuldade de se controlar, de ficar mais tempo sentada no lugar, né, que se agita muito corporalmente, que fala muito sem controle, não consegue ouvir o outro, atropela a fala tanto dos amigos quanto do professor, e uma agitação corporal também, né, de não ficar parada, de não ficar sentada.(Marta)

Ela levanta mil vezes do lugar e pede para ir ao banheiro muitas vezes. Não espera a vez para falar, não respeita este tipo de combinado, é impulsiva e quando vê ela já bateu no amigo mesmo não querendo fazer isso. (Clara)

Uma criança agitada não necessariamente tem a ver com alguma coisa que é ruim. É uma criança que levanta, não consegue ficar sentada, que fala sem esperar que o outro termine, deixa as coisas cair. A gente sempre tem essa criança em sala. (Ângela)

A respeito da desorganização do material, Juliana comenta que "normalmente a mesa dela é bastante desorganizada, acaba deixando cair as coisas e tal"'.

Também foi comum a referência à faixa etária e àquilo que é próprio da idade, como coloca Meri: "Eu acho que tem uma agitação normal que é própria da idade, que isso não é problema nenhum. A gente até espera que as crianças sejam bem saudáveis”. Juliana entende que "com sete, oito anos eles não têm uma competência, uma habilidade de concentração muito grande". Semelhante ao fragmento anterior, Rose aponta que "crianças de seis e sete anos precisam muito circular, são muito corporais. Acho que a agitação tem muito a ver com a característica da faixa etária”.

Clara, que em seus 18 anos como professora diz nunca ter levantado a hipótese de que algum aluno tivesse TDAH, considera “que as crianças no geral são agitadas porque é impossível você querer que uma criança fique ali sentadinha cinco horas. Eu acho que a criança tem uma energia, ela gosta de correr, de brincar". Notamos que hoje o espaço para o corpo, para brincar e correr foi drasticamente reduzido, ao passo que as exigências disciplinares aumentaram. O recreio nas escolas foi encurtado e as aulas de Educação Física 
já não parecem ser mais suficientes para uma energia que sabemos ser consubstancial à infância e que exige um espaço de descarga motora (muitos colégios norte-americanos nem possuem recreio). Há uma disparidade entre um corpo que é contido e exigido em seus aspectos cognitivos e uma infância que, como sabemos, está mergulhada constantemente num excesso de informações e de estímulos digitais.

Como discutimos no Capítulo 3, nossa época é marcada pela velocidade e pelo imediatismo, e isso, logicamente, se reflete no comportamento das crianças, que demandam um outro espaço e tempo escolar. Assim, pensar em longas aulas expositivas, nas quais os alunos devem permanecer sentados em suas carteiras prestando atenção no que o professor fala, nos parece não só incongruente mas também indutor daquilo que tantas vezes é entendido como manifestação de comportamentos hiperativos e desatentos.

O próximo fragmento nos apresenta um exemplo sobre o aspecto da idealização da criança:

O F. não consegue manter a atenção na atividade por um tempo. Não consegue... Quer dizer, não consegue dentro dos padrões que a gente considera atenção. Porque a gente tem isso de achar que o aluno que presta atenção, ele fica sentado, te olhando, que consegue ficar ali parado. Mas não. As vezes, o aluno está andando pela sala porque não consegue ficar sentado e está me ouvindo o tempo todo, ele pode estar até virado de costas. (Marta)

Aparece aqui a alusão à criança ideal, "A" criança, que corresponderia à criançaboneca que ficaria quieta em sua carteira olhando para a lousa, imagem sobre a qual opera, ainda que muitas vezes de forma não manifesta, o imaginário de muitos professores. Inevitavelmente, todo ser humano possui ideais para si e também para a infância, para a criança. O que a Psicanálise pode acrescentar para nós é a importância de estarmos advertidos sobre esse fenômeno inconsciente para que possamos levar em consideração o modo como isso incide sobre nós e determina nossos atos, julgamentos e pré-concepções.

As entrevistas nos revelam que algumas professoras parecem possuir esse discernimento de que, embora partilhem de um ideal de aluno comportado, quieto e atento, na prática as coisas não funcionam assim, e aquele aluno agitado que aparenta estar disperso está na realidade muito "ligado" no que está sendo dito e, da sua própria maneira, está participando da aula. Sobre esse aspecto, Rose e Marta comentam:

Eu reparo muito que, às vezes, a gente tem um ranço da educação de que a criança agitada, ela tumultua, e a tendência do professor é sossegá-la. Mas esta criança é participativa do jeito dela e é extremamente produtiva. (Rose) 
A gente tem um ranço muito forte de escola conservadora que para aprender tem que ficar quieto, que para aprender tem que prestar atenção, que só aprende quem escreve direitinho, a gente carrega esse ranço. Eu mesma faço um esforço e acho que muitas situações eu consigo deixar de lado e ver que aquele menino está aprendendo, mesmo que ele não entregue o trabalho como o outro. (Marta)

Dentre as entrevistadas, quatro professoras associam diretamente a criança agitada à criança com o diagnóstico de TDAH, como é o caso de Roberta que ao ser perguntada sobre a criança agitada prontamente responde: "Eu acho assim, sobre o transtorno de déficit de atenção e hiperatividade (...) são casos que fogem ao extremo”. Contudo, outras professoras fazem questão de marcar essa diferença entre a agitação e o TDAH.

Agora, tem o agitado, que é uma criança, né, dentro dos padrões assim e tem aquelas que dentro da agitação têm umas características mais específicas. (Marta)

Uma criança agitada, daquilo que a gente vê na sala de aula, é uma criança que... E que não necessariamente tem a ver com alguma coisa que é ruim assim. É uma criança que levanta, que fala sem esperar que o outro termine, que chama a gente por diversas vezes, que deixa coisa cair. Isso que a gente tem ideia de uma criança assim. (Ângela)

Meri compartilha dessa mesma opinião e a expressa:

Então, é diferente. Eu acho que tem uma agitação natural da idade e tem uma que não é esperada, que é essa agitação com baixíssima concentração, com uma inquietação constante, com movimento do corpo aparente, constante, uma desorganização do material, uma desorganização do próprio corpo. (Meri)

Débora considera que a criança agitada é antes de tudo uma criança angustiada e que isso gera reações motoras de inquietação.

Ela não dá conta do recado, sabe? Ela fica aflita, fica ansiosa. E ela chega na sua mesa e você pede para ela reler e ela não tá dando conta. Você percebe na cara dela, você vê a fisionomia da criança de frustração, sabe? E a autoestima no pé. É uma criança que você vê que não tá dando conta do recado e que ela precisa de um suporte, um suporte externo.

De modo similar, Roberta comenta:

Uma criança agitada é aquela que não consegue realmente se controlar, você vê que independe da vontade, ela sofre com aquilo. Eu já tive caso de crianças que você vê, eles falam "eu não consigo", eles querem melhorar, eles querem se esforçar, mas eles não conseguem. É diferente daquela criança que é bagunceira, né, que é por natureza, falta um pouquinho de limite aqui e ali. (Roberta) 
Esse suporte externo ao qual Débora faz referência nos faz pensar num apoio que viria a ajudar a criança frente às suas dificuldades. Deixemos o leitor com um questionamento, ou antes, uma provocação: os medicamentos não entrariam neste cenário como uma espécie de apoio que essa criança solicita? E a melhora, que por vezes é atribuída à administração de psicofármacos à criança, não estaria associada justamente ao fato de ela se sentir apoiada, amparada em suas angústias e reconhecida em suas dificuldades?

Não pretendemos oferecer respostas a essa hipótese vislumbrada neste momento da apresentação das entrevistas, mas percebemos como as questões que permeiam a fala das professoras não se encontram isoladas e estanques, mas se relacionam mutuamente na medida em que uma confere significado a outra num continuum que só poderá ser compreendido $a$ posteriori.

Muitas entrevistadas localizam um sofrimento na agitação motora da criança, uma vez que percebem que ela não consegue controlar os chamados "impulsos" que a acometem e invadem. Neste ponto, a Psicanálise concorda com tal afirmativa, mas de um outro lugar, pois considera esta agitação como um sintoma psicomotor que não está localizado no nível da consciência e do controle egoico. Situa-se no inconsciente, lugar ao qual não temos acesso direto e que nos invade com seu chamado e imposição de escuta.

Acompanhamos por meio das falas das entrevistadas que a agitação está presente em todas as salas de aula e que o modo como isso é tomado pelo professor apresenta nuances variadas. Novamente vemos tratar-se do ideal de criança e de aluno que é tomado como modelo, pois o entendimento do que seria uma agitação normal, condizente com a faixa etária à qual muitas das professoras fazem menção, e o que seria considerado excessivo são critérios extremamente subjetivos.

Conforme discutido na parte teórica deste trabalho, reside justamente aí uma das críticas fundamentais ao diagnóstico clínico de TDAH, que se baseia sobretudo na observação dos professores sobre o comportamento do aluno na escola. O que é entendido como excessivo para uma professora pode não ser para outra. Por exemplo, Meri diz que a agitação a preocupa quando "vem com um olhar disperso, movimento constante do corpo e falta de organização, diferente da agitação normal e esperada. Ai sim me preocupa e eu levanto a hipótese observando as atitudes das crianças na sala”. "Tem o agitado dentro dos padrões e tem aquele com características específicas", comenta Marta. O que se entende por agitação normal e esperada? Que padrão é esse? Tratar-se-ia antes de um limiar de incômodo que a agitação provoca para este professor? 
Com isso, queremos dizer que cada sujeito tem um olhar, uma forma de pensar e uma reação própria frente àquilo que se lhe apresenta. Consideramos importante precisar isso, para que os professores sejam alertados sobre suas idealizações, pois entender que a agitação da criança se refere a um transtorno psiquiátrico tem consequências que muito provavelmente não são consideradas quando tal hipótese é levantada no interior das escolas.

No próximo relato, a professora reflete sobre esse aspecto quando diz:

A maioria dos professores sempre levanta a hipótese: "Será que ele tem TDAH?". Acho que os professores têm que pensar antes, porque se vai para o neuro, com certeza, vai sair com alguma coisa... O olhar do professor pode mudar muito. Você tem que esgotar todas as possibilidades para pensar em algo. Pode ser uma fábrica de gerar pacientes e você vê os neuro enriquecendo com tudo isso. (Rose)

Destacamos a expressão utilizada por Rose, "fábrica de gerar pacientes", para comentar sobre o aspecto econômico presente na proliferação de diagnósticos de TDAH entre crianças e jovens atualmente. De acordo com a própria observação desta professora, o que vemos de fato ocorrer é a valorização do aspecto lucrativo em sua dimensão gananciosa, visto os lucros exorbitantes das indústrias farmacêuticas. Para os laboratórios, quanto mais diagnósticos forem dados, mais remédios prescritos e consequentemente mais dinheiro envolvido. Não é à toa, portanto, que vemos pesquisadores, hospitais e grupos de apoio a famílias e crianças com TDAH serem apoiados e financiados pelos laboratórios que produzem a Ritalina e o Concerta.

Serão todas as crianças de hoje desatentas?

Várias professoras se referem à criança desatenta pela via da distração e da falta de concentração e de organização. Para a maioria, a desatenção não está necessariamente associada a uma agitação. "Não tem essa coisa de se movimentar", diz Juliana. O mesmo vale para Clara, quando afirma que crianças com dificuldade de concentração se controlam corporalmente, mas não estão atentas, e Ângela, que comenta: "A desatenta não necessariamente é agitada. O perfil dela pode ser desatenta, mas ela não tem esse comportamento de levantar toda hora e falar".

Percebemos que, na maioria das vezes, quando perguntadas sobre o que pensam a respeito da desatenção, as professoras começam a discorrer sobre algumas características do 
comportamento da criança e rapidamente associam isso ao TDAH. A seguir, são trazidas algumas vinhetas que nos revelam a preponderância da interpretação medicalizante acerca da desatenção.

Tenho este ano dois alunos extremamente desatentos, mas que não são agitados. Eles estão assim, por exemplo, copiando alguma coisa da lousa ai eles param, ficam olhando para a janela, a porta. Ás vezes, o lápis mesmo, ficam olhando para o lápis e fica desatento mesmo. Não tem agitação, essa coisa de se movimentar. Ficam meio desligados. Eu suspeito que tenham um transtorno. Esses dois eu acho que têm um déficit de atenção, teria que ser averiguado. (Juliana)

Está o tempo todo se distraindo com o estojo. Para pegar um lápis, ela fica o tempo todo demorando para pegar esse lápis, aí na hora que ela pega o lápis ela tá se preocupando em pegar a borracha. Alguém do lado fala alguma coisa e ela já vai para outro assunto... Ela tá sempre em movimento, ou mexendo no estojo, ou mexendo na mochila, ou apagando e escrevendo várias vezes o cabeçalho. Se você olhar, ela tá sempre fazendo alguma coisa. Eu acho que ela tem um déficit de atenção. (Vera)

É uma criança angustiada, que parece que sai fora, né, não se concentra e não presta atenção no que eu falo... Não considera nada do que eu falo e não registra aquilo, tem dificuldade com o enunciado. Não entende e precisa muito mais da minha intervenção. Acho que a gente tem em média pelo menos um aluno com déficit de atenção por sala. (Débora)

Estas professoras demonstram pensar num "corpo-doente" e não em problemas ocorridos no desenvolvimento, em suas etapas maturacionais, conforme a teoria piagetiana, por exemplo. Ao pensar-se num "corpo-doente", espera-se que o médico intervenha para solucionar o caso. Estas professoras presumem quase que "naturalmente" a existência de distúrbios orgânicos, o que revela o poder do discurso médico, ou, mais precisamente, do discurso tecnocientífico.

Em alguns relatos, notamos como as professoras, a partir do momento em que levantam a suspeita de que a criança tenha TDAH, já partem de pressupostos que possivelmente revelar-se-ão verdadeiros, dada a permeabilidade da criança ao discurso que vem do outro. A Psicanálise nos revela a potência do olhar do outro na constituição do sujeito. O sujeito do qual ela nos fala é efeito de discurso. Que esperança é depositada na criança quando se entende que haveria uma limitação de ordem neurológica afetando sua capacidade de concentração? Como poderá essa criança de fato se sair bem na escola quando o outro, que deveria apostar no seu futuro, lança nela, antes, uma "profecia" como, por exemplo, a que encontramos na fala de Débora: “A criança com o déficit de atenção não vai conseguir ler $e$ entender direito. Tem esta limitação”. "Uma criança de déficit de atenção não dá conta, não entende”, assinala Roberta. Para Meri, "essa criança precisa muito mais da intervenção do 
professor para entender o enunciado. Ela não consegue responder sem ter ajuda do professor no momento". "Eles vão acabar apresentado dificuldade por não conseguir prestar atenção”, diz Juliana.

Sabemos que a incidência de um transtorno sobre o ideal que a criança condensa constitui "uma lesão que pode atingir a rede de significações nas quais a criança se estrutura como sujeito" (Vorcaro, 2011, p. 227). Sendo assim, o efeito da nomeação de um transtorno ou até mesmo de sua suspeita ativa acepções que as professoras trazem consigo sobre as possibilidades da criança e isso afeta diretamente a sua subjetivação. Em consequência disto, o fato de que um aluno desatento demande sempre ajuda e indique não estar compreendendo os enunciados, tal como foi exemplificado por algumas professoras, diz mais respeito, possivelmente, ao fato de ele estar respondendo a partir do lugar onde foi colocado e sobre o qual são depositados estes saberes do que a algo que estivesse posto antes disso. As falas das professoras sobre o aluno desatento condensam, portanto, uma série de concepções que mantém a criança exposta a uma desmedida operação de aderência imaginária a essas concepções.

É importante ressaltar que, tal como foi discutido no item anterior sobre a agitação, percebemos aqui que a referência à criança desatenta traz em si a alusão a um ideal de aluno. Apesar disso, algumas professoras puderam reposicionar suas falas ao se darem conta desse padrão de aluno que é comumente tomado como indicação e exemplo de atenção na escola aquele que fica sentado em sua carteira, calado e olhando para a lousa. A surpresa com as crianças supostamente desatentas fez Ângela questionar esse modelo de atenção e de postura da criança.

A criança desatenta está, em determinados momentos, parece que tá longe daquilo que você tá falando... e às vezes também só parece que tá longe, porque se você retoma ou pergunta, ela é capaz de responder. Mas na hora você fala: "Nossa, parece que estava em outro mundo". (Ângela)

Rose, por sua vez, parece se intrigar com a desatenção constante da criança:

São crianças que não estão inteiradas no que tá acontecendo. Então, ela escuta, porém, ela não está processando o que você tá falando. Às vezes, ela pode até estar te olhando, mas ela não tá te ouvindo, prestando atenção no que você está dizendo. Então, ela está de corpo presente, mas ela perde algumas coisas. Talvez a maior parte das coisas... Será, talvez, por que elas estejam prestando atenção em outras coisas, algo que seja mais importante para ela? (Rose) 
Este fragmento nos revela uma regularidade encontrada em muitas das entrevistas e que está relacionada à percepção de certo desinteresse e apatia dos alunos pelo aprendizado escolar. Tais situações, de acordo com as professoras, costumam ser percebidas frequentemente dentro das escolas. Para esta discussão, iremos nos remeter ao mal-estar contemporâneo, decorrente de uma sociedade cujas relações privilegiam o prazer e o ter em detrimento do ser. Neste cenário, a transmissão de saberes e de valores de uma geração para a outra fica bastante comprometida.

Em alguns relatos, notamos como as professoras parecem encontrar cada vez mais dificuldade para envolver o aluno e cativar sua atenção.

Elas ficam mexendo no material do estojo, ou trazem coisas de casa, pegam o caderno de desenho e começam a desenhar durante a aula enquanto eu explico. Estão sempre fazendo outra coisa. Parece que não estão interessadas em nada. (Meri)

Lógico que quando a gente dá uma aula interessante eles ficam concentrados. Penso no quanto que eu estou contribuindo para que essas crianças estejam desatentas e agitadas não porque elas tenham um transtorno, mas porque a sociedade está fazendo isso com ela e na escola não tá interessante. (Juliana)

Ela está sempre arranjando alguma coisa para conversar, nunca está interessada na aula. Sempre quer saber o que será feito a seguir. "Posso desenhar?" "Posso pegar um gibi?" Eles não conseguem ficar sentados muito tempo. Então, eu tento assim: se vou dar língua portuguesa, depois preciso dar um momento de relaxar para fazer um desenho, fazer algo fora da sala, uma brincadeira. (Vera)

A criança desatenta, você precisa mostrar para ela a importância de vir para a escola, o porquê ela vem para a escola, a importância do que ela está aprendendo, reposicionar ela na sala e retomar o que ela tá fazendo pra voltar o foco dela, porque ela se perde. Tem a tendência a não prestar atenção no que tá fazendo... Tem uma série de coisas para pensar, ainda mais nesse mundo com computador, brinquedos, filmes. Então, eles têm uma gama de coisas para pensar muito interessantes, que competem com a escola. Então, eles são desatentos não porque são desatentos, mas porque eles têm muita coisa para pensar. (Rose)

Encontramos nestas descrições certo desconforto em torno do contexto escolar atual.

Parece haver um desencontro e uma dificuldade do adulto de se endereçar à criança (e ao jovem) nos dias de hoje de modo a chamar sua atenção para os conhecimentos provenientes do universo escolar.

Para ampliar essa reflexão, recorreremos ao conceito de nativos digitais e imigrantes digitais, formulado por Marc Prensky (2001). Segundo o autor, o motivo do declínio da educação nos EUA refere-se ao fato de os alunos terem mudado radicalmente, "os alunos de hoje não são os mesmos para os quais o nosso sistema educacional foi criado”, frisa Prensky 
(2001, p. 1). Ele atribui a responsabilidade por essa mudança à rápida difusão da tecnologia nas últimas décadas e entende que, por terem nascido cercados e já utilizando diversas ferramentas da era digital, os alunos de hoje processam as informações de um modo bastante diferente dos adultos das gerações anteriores. O autor chama esses "novos" alunos de hoje de nativos digitais, ou seja, "falantes nativos da linguagem digital dos computadores, videogames e internet", distinguindo-os dos imigrantes digitais, que apesar de aprenderem a utilizar a mesma linguagem fluentemente, carregam consigo um "sotaque" inevitável (p. 1). Tal sotaque, que persiste ainda que o aprendizado seja rigoroso, pode ser identificado, por exemplo, na leitura de manuais, necessidade de imprimir mensagens de e-mail para lê-las e ligações para checar se a pessoa recebeu o e-mail.

O problema referente à educação reside na linguagem utilizada pelos professores (imigrantes) para ensinar os alunos (nativos). Um aspecto evocado por muitas professoras diz respeito a uma inquietude por parte dos alunos que sempre querem saber o que será feito a seguir. Entendemos que essa atitude pode não estar relacionada a uma hiperatividade, à qual é comumente associada, mas sim ao modo acelerado como os alunos de hoje processam as informações. Assim, uma explicação longa e exaustiva sobre um determinado assunto pode se transformar rapidamente numa aula entediante e desinteressante para a criança, que se apresenta aos olhos do adulto como desatenta. Os nativos digitais preferem realizar diversas tarefas ao mesmo tempo, estão acostumados com a rapidez de baixar músicas, filmes e mandar mensagens instantâneas.

Esta discussão nos leva a compreender as mudanças na educação contemporânea, relacionadas ao que Gilles Lipovetsky (2005) chama de sociedade hipermoderna, e Bauman (1998), de sociedade pós-moderna. Os autores utilizam-se destes conceitos para evidenciar que, atualmente, os professores necessitam "estabelecer novos laços sociais, criar outras maneiras de lidar com a educação, as escolas, os alunos e a sociedade” (Mrech, 2005, p. 19). As mídias eletrônicas introduziram a diversificação e tornaram obsoletos muitos dos conhecimentos ensinados nas escolas. Mrech (2005) localiza aí os impasses enfrentados atualmente pela educação, quando parte de concepções que "tendem a se direcionar pelas vertentes universalistas de educação, enquanto a sociedade e a cultura estão se encaminhando de forma vertiginosa para parâmetros cada vez mais imprecisos de estruturação" (p. 21).

Os parâmetros de trabalho do professor mudaram, analisa Mrech (2005). Assim, é digno que as professoras entrevistadas se perguntem como educar e capturar a atenção dos alunos, seduzidos a todo o momento pela realidade virtual. "O educar não diz mais respeito a apenas transmitir informações, passar um conteúdo. O educar e o ensinar atuais 
também implicam o professor e o aluno como sujeitos, na construção de algo novo", aponta Mrech (2005, p. 22).

De acordo com Melman (2009), na contemporaneidade há uma crise relacionada a uma negação daquilo que é transmitido pelas figuras de autoridade em geral.

O problema não é que esses valores tradicionais lhes pareçam desusados ou antipáticos, mas que eles [os adolescentes] têm o sentimento que tais valores não os preparam mais para enfrentar o mundo social no qual eles já estão mergulhados precocemente e que eles têm que enfrentar. (Melman, 2009, p. 129)

Cabe aqui fazer um parêntesis para animar algo que desenvolveremos adiante: a consequência da perda da tradição na sociedade moderna, tema extensamente analisado por Arendt (1957), ao relacioná-lo à desautorização e à crise da autoridade. Se nas sociedades contemporâneas a escola é responsável por apresentar a tradição às novas gerações por meio da sistematização do conhecimento, havemos de convir que a autoridade foi diretamente atingida pela crise da tradição. Enxergamos o reflexo disso na fala de muitas professoras sobre o desrespeito em sala de aula.

Uma cultura que não exige uma renúncia ao prazer, mas, antes, oferece a ilusão de que é possível gozar sem limites, acaba por enfocar a valorização narcísica. No tocante a isso, qualquer entrave ao qual a criança tenha que se submeter e se assujeitar tende a ser rechaçado na busca deste ideal de felicidade e satisfação. A falta de limites, a indisciplina, a desvalorização do saber, não submissão a regras e o desrespeito à autoridade são alguns dos exemplos trazidos por essas professoras e que entendemos estarem relacionados a certo tipo de discurso que reina na atualidade e que determina um imperativo de gozo. Estamos nos referindo aqui à formulação lacaniana do discurso do capitalista que, de acordo com Voltolini (2011a), sob o matema que lhe foi forjado,

escreve um circuito fechado que enoda sujeito e objeto numa relação de complementaridade e de êxtase, anuncia um tipo de laço no qual o gozo ocupa um papel hegemônico em comparação com o desejo. "Goze!" é, sobretudo, um mandamento capitalista.

Por outro lado, como todos sabem, o capitalista é aquele cuja fórmula se ouve sempre: "espero não ter deixado 'nada a desejar"'. (p. 36)

A vigência deste discurso prevalecente em nossos dias afeta diretamente tudo aquilo que se passa no campo educativo, na medida em que é via educação que o sujeito se depara com limites, restrições, contornos e frustrações, que visam em última instância promover o laço social e inserir o sujeito na cultura. Daí decorrem os vários impasses da educação 
contemporânea, relacionados à socialização, ou seja, a tudo aquilo que se passa na relação com a alteridade, já que "educar é socializar” (Voltolini, 2011b, p. 36).

A partir de uma leitura psicanalítica sobre a insistência da desatenção nas escolas, podemos entender ainda que tal desatenção estaria em alguns casos relacionada a um sintoma, ou seja, a uma mensagem endereçada ao outro, no sentido de dizer que aquilo que lhe está sendo ofertado está desconectado com o seu desejo. A recusa expressa por esse desinteresse, indiferença e falta de atenção pode bem ser uma resposta subjetiva frente a um tal mal-estar. A escola e os professores, por seu lado, ignoram muitas vezes a implicação que possuem para com a desatenção do aluno e a localizam em termos patogênicos quando levantam a hipótese de um déficit. Por essa falta de questionamento, entendemos que, com suas práticas, as escolas podem acabar favorecendo a perpetuação dos problemas sobre os quais se queixam.

Como as professoras manejam os impasses em sala de aula? Estratégias de enfrentamento.

Verificamos que, independentemente da presença de um diagnóstico médico de TDAH, todas as professoras desenvolvem estratégias próprias para lidar com os alunos que se apresentam agitados e desatentos em sala de aula e parecem satisfeitas com o alcance de suas ações. Muitas intervenções referem-se a mudar a criança de lugar na sala de aula, sentar-se ao seu lado para ajudar na tarefa, pedir para sair da classe e tocar o corpo da criança para atrair sua atenção. Marta, por exemplo, procura “colocá-lo num lugar mais privilegiado, né, estabelecer alguns combinados com a criança. Então, às vezes, eu preciso colocar a mão nele e falar: 'Vamos acalmar, senta'”. Ângela possui uma compreensão sobre a importância de se atentar para o fato de que as crianças possuem ritmos diferentes e por isso diz que:

Procuro ter essas crianças mais próximas. Propiciar que ela possa estar do lado de uma parceria, de um outro colega que também possa ajudar, retomar sempre. Eu procuro sempre, sei lá, se a criança está me chamando muito, chegar perto e perguntar: "Você está precisando de alguma coisa, eu posso te ajudar com o quê?". Ou então: "Espera um pouquinho que eu já venho". Procurar ter uma conversa, não de ficar toda hora chamando a criança e expondo, isso eu percebi que começa a gerar mais agitação ainda. Então, é estar sempre mais próximo e falando mais baixo... E procurar acho que, se eu vejo que ela terminou a atividade, então pega um livro pra ler... porque, por exemplo, eu tenho uma criança que é bem agitada, mas se ela termina e pega um livro, ela fica ali um tempo lendo o livro e ela gosta. (Ângela) 
A estratégia acima seria uma dentre tantas outras possíveis e benéficas para todos os alunos e que pode ser oferecida a todos os professores porque as crianças possuem um tempo próprio para realizarem as tarefas. Acontece que quando se pensa sobre "A" criança, pressupõe-se um ritmo desejável, natural e esperado, baseado na ideia construída como "universal" e se esquece de que cada criança possui o seu ritmo particular.

Juliana descreve sua atuação da seguinte forma:

Quando eu percebia que ele tava ficando muito agitado, eu pedia para ele sair. "Vai até o banheiro, vai buscar alguma coisa para mim, pega um livro que eu tô precisando." Para ele sair. Ele precisa sair. (Juliana)

Os excertos abaixo apresentam outros exemplos dessas estratégias.

Quando alguém está muito agitado, eu dou umas dicas, falo: "Respira, fica tranquilo". E a criança vai fazendo isso melhor. Essas crianças que têm essa questão da concentração, eu chamo a atenção de diversas formas - "Ah, presta atenção que agora a próxima coisa que eu perguntar é você que vai responder" - e isso ajuda. E às vezes, quando é demais, a criança tem que sair da situação. Quando está numa roda(...) chega uma hora que eu falo: "Não, você não tá conseguindo ficar. Você vai sentar e quando você achar que você consegue você me procura e você volta". (Clara)

Tem uma criança agitada na sala que eu percebi que ela precisa estar o tempo todo trabalhando. Eu preciso ocupar essa criança para que ela consiga administrar esta energia vital excedente que ela parece ter, pra ela produzir e não virar uma criança que está o tempo todo chamando a atenção. (Rose)

Clara, que, como foi dito anteriormente, considera extremamente difícil encontrar uma criança com o diagnóstico de TDAH e revela que ela própria nunca aventou essa hipótese em seus quase 20 anos dentro de sala de aula, nos conta muitos de seus manejos:

Eu faço assim: falo baixo, eu uso mil estratégias para eles prestarem atenção, eu canto muito, então, eles sabem que quando começo a cantar eles têm que fazer silêncio. Às vezes, eu conto e brinco que, "ah, vamos ver, hoje contei até dez, amanhã vou contar até cinco". Faço um desafio e é muito bacana. Eu trabalho também com metas, então, quando começa o mês, a gente faz uma roda e cada um pensa na sua meta. Lógico que não é fácil, é um trabalho de formiguinha, de dia a dia. (Clara)

Vera aborda a questão de ajudar a diminuir a ansiedade:

Dou um momento para fazer um desenho ou eu dou um momento para ler um livro, pra fazer um relaxamento. As vezes, eu faço uma atividade fora da sala, faço uma leitura, uma brincadeira fora da sala, pra voltar depois de novo e produzir. Porque se eles ficarem 
muito tempo sentados, e um atrás do outro, é muito pra eles. É uma estratégia minha que ajuda bastante. (Vera)

Esta professora mostra uma preocupação em observar o que é importante para o aluno agitado e comenta sobre um caso em que ela percebia que a criança tinha a necessidade de correr:

Eu comecei a fazer o seguinte: eu percebi que aquele aluno tem essa necessidade de correr, ele fica inquieto muito tempo sentado. Então, vai ter vezes que eu vou deixar ele sair correndo. Percebi que ele precisava daquilo.

Estas vinhetas puderam nos mostrar os múltiplos repertórios que as professoras inventam, no encontro singular com cada criança, para dar conta dos embaraços escolares. Todas desenvolvem intervenções baseadas na experiência que possuem e buscam criar condições de tornar possível o aprendizado. Mais adiante, poderemos articular isso frente à interpelação da entrevistadora sobre o valor e o sentido do diagnóstico de TDAH na prática educativa, uma vez que essa busca pelo manejo mais adequado e por estratégias de enfrentamento parecem independer de tal informação. Assim, levantaremos por enquanto apenas duas interrogações sobre o motivo do interesse e da insistência dos educadores em identificar um transtorno por detrás de um comportamento: a serviço de que e de quem isso está posto? Em que essa informação muda sua prática e suas intervenções?

Ao entendermos que o vínculo educativo entre professor e aluno é da ordem do particular, deduzimos que é impossível estandardizar respostas prontas que deem conta de garantir que tal vínculo tenha sucesso. Para que haja um encontro produtivo, é necessária uma invenção que suporte o vazio instalado diante de um saber. O professor precisa tolerar não saber antecipadamente estratégias que podem ser aplicadas, a fim de deixar espaço para que algo seja construído a partir dessa relação. Assim, o que funciona para um professor não necessariamente funcionará para outro. E mais: o que funciona para um professor com uma criança poderá também não funcionar com outra criança, ainda que ambas apresentem questões que pareçam semelhantes. Portanto, é justamente neste encontro que o professor poderá colocar as suas marcas, sem a intenção de homogeneizar ou padronizar estratégias. A vinheta a seguir aponta esse tipo de reflexão sobre a implicação e responsabilidade do professor:

Eu acredito muito nessa coisa de cada criança, não tem como saber antes de conhecer o aluno o que vai dar certo. Mesmo que você tenha uma criança lá que seja um bom aluno, ele 
também precisa de uma atenção especial. A gente dá uma aula para todos, mas cada um está lá de um modo diferente. Um desatento, outro de outra forma. (Ângela)

Nos próximos fragmentos, as professoras abordam esse mesmo aspecto, ressaltando a importância do olhar individualizado e do vínculo que o professor consegue estabelecer com a criança.

Você precisa ter um olhar para cada um. Uns precisam de mais atenção, outros precisam de menos. Tem alunos que justamente o que eles precisam é de menos atenção. Então, eles solicitam e você precisa largar para que eles se desenvolvam, porque você sabe que ele é capaz. Tem aqueles que precisam da sua ajuda e eles não solicitam. Então, eu acho que não existe uma receita, uma estratégia que você fala: aplica essa na sua sala que vai funcionar. Então, depende muito do perfil do grupo, como o grupo funciona entre ele e com a professora. Eu acho que no fim a professora faz toda a diferença. (Roberta)

Eu percebo que tem muito da minha postura em relação a ele. Eu valorizo tudo o que ele sabe, porque ele é extremamente inteligente e ele adora ciências, né? Então, sempre que eu posso eu deixo ele fazendo outras coisas que a classe não tá fazendo e tudo bem, porque eu sei que ele tá aprendendo. Eu consegui criar um vínculo importante com ele e se ele se agita basta eu conversar com ele e pedir para sair um pouco da sala. Eu entendo que quando ele não aguenta ele sai da sala, vai tomar uma água e volta e tudo bem. (Marta)

Sempre falta alguma coisa aqui e outra ali. Eu tento olhar para cada criança, pra o grupo dos 28 e pra cada um e ver o que eles estão precisando naquele momento pra aprender, né? Às vezes, é um colo, às vezes, é contar uma coisa, às vezes, é uma bronca. As crianças são diferentes, e é o desafio do professor lidar com essas crianças, com essa diversidade e tentar ajudar cada um a caminhar no processo de aprendizagem. (Clara)

Em Algumas Reflexões sobre a Psicologia do Escolar, Freud (1914c/1996), ao testemunhar suas experiências como estudante do liceu, afirma: "É difícil dizer se o que exerceu mais influência sobre nós e teve importância maior foi a nossa preocupação pelas ciências que nos eram ensinadas, ou pela personalidade de nosso mestres" (p. 248).

$\mathrm{O}$ autor se referia neste discurso a esse algo a mais na personalidade daquele que professa e que influencia e toca o aprendiz. Faremos agora um paralelo da importância concedida a este "algo" para nos remeter ao olhar do professor frente aos impasses escolares. Inferimos a partir da colocação de Freud que é antes a personalidade do professor, e não a técnica ou o saber antecipado, que fará a diferença nas atitudes e no modo de lidar com a criança. Este algo a mais que não pode ser ensinado não é um dom que tampona uma falta, tampouco um saber que apaga as incertezas, mas diz respeito à construção de um saber-fazer a partir das experiências singulares vividas no cotidiano do exercício docente.

Nessa direção, a Psicanálise propõe que os professores se autorizem a inventar maneiras próprias de lidar com isso que insiste e que diz respeito ao exercício de uma 
profissão impossível e que não enveredem na busca da instrumentalização técnica de ferramentas teóricas derivadas do conhecimento científico acerca do desenvolvimento e tratamento de crianças, mas que caminhem por lugares desconhecidos e encontros inesperados.

Sabemos, pela Psicanálise, da inevitabilidade de um mal-estar permanente advindo do encontro com o outro. Isso não quer dizer, entretanto, que o sujeito não possa ter ações para dar conta dessa tarefa incessante, pois, por princípio, sempre haverá problemas. Novamente fazemos referência aqui ao impossível da educação, que não é o mesmo que irrealizável ou impraticável. Nunca se ensina de uma mesma forma, pois os alunos e o contexto sempre mudam, exigindo, assim, uma constante reformulação por parte daqueles que educam.

A Psicanálise evidencia, portanto, que nunca haverá como atingir uma prática idealmente perfeita (nem um professor idealmente perfeito), pois a conjuntura é sempre outra e não pode ser prevista. Pelo fato de cada ser humano ter sua própria singularidade, não há uma forma única de organização que dará conta de tudo e deixará todos contentes.

Como pudemos perceber nos excertos apresentados, estas professoras encontram maneiras de enfrentar o mal-estar no contexto escolar e criam condições de enfrentamento. Apesar da insistente demanda ao suposto saber dos "especialistas" (seja em reuniões de orientação, seja em cursos de especialização) sobre como educar o aluno e como fazer para ensiná-lo, respostas que sabemos ser impossíveis, o que ocorre no dia-a-dia com estas professoras parece nos falar ainda de um outro cenário. Ainda que algumas pareçam iludidas sobre a existência de uma receita sobre formas pragmáticas de atuação para superar e, quem sabe, evitar o mal-estar na educação, observamos que no encontro com o real da situação apresentada no dia-a-dia em sala de aula, elas dão conta de inventar modos singulares de atingir a criança.

Ainda em relação a esse mal-estar e aos impasses da educação, entendemos, por meio de uma leitura psicanalítica, que isso deriva da impossibilidade de educar as pulsões. Elas continuam sempre a ser parciais e não se ligam a um objeto específico. O que queremos afirmar com isso? Pretendemos dizer que, ao contrário do que é postulado pela ciência moderna, a razão não é capaz de controlar tudo e eliminar a barbárie, justamente pelo fato de que as pulsões não podem ser domesticadas. O ideal do Iluminismo, de que a razão daria conta de impedir os conflitos e de que por meio da educação o ser humano poderia alcançar níveis elevadíssimos, revelou-se falacioso com a Primeira Guerra Mundial, que chacoalhou tal pretensão ao mostrar que a ciência poderia matar os homens, e com a Segunda Guerra Mundial, que evidenciou a barbárie à qual a civilização poderia chegar. 
A respeito disso, vale citar Adorno (2006), que em virtude de tal realidade já havia concluído que a educação não necessariamente é um fator emancipatório e que, após Auschwitz, é imprescindível a existência de uma crítica permanente para evitar que aquilo se repita. Como um país tão educado e culto como a Alemanha pode chegar à barbárie do nazismo? A educação, portanto, não é capaz de evitar a barbárie, mas sem ela estaríamos muito mais expostos a esse risco, pois é preciso que haja recalque. A despeito do reconhecimento dessa impossibilidade, a ciência moderna insiste na ilusão de que seria possível eliminar completamente o mal-estar na civilização. E os professores, balizados por essa lógica e pela aderência ao discurso científico, creem e continuam a buscar um modo de evitar a ocorrência de impasses na educação, iludidos por essa falácia que a ciência pretende vender $^{38}$ como verdadeira.

Os efeitos nefastos da incidência do discurso médico hegemônico sobre o discurso pedagógico nos tempos contemporâneos revelam-se na medicalização desmedida, que apela para o silenciamento dos conflitos humanos, negando-os como inerentes à constituição da subjetividade e ao encontro com o outro.

Afinal, quem é a criança com TDAH? Entre o esperado e o inesperado.

A análise dos sentidos atribuídos aos comportamentos agitados, impulsivos e desatentos das crianças nos leva a interrogar: afinal, o que quer dizer Transtorno de Déficit de Atenção e Hiperatividade? Como é a criança que os professores entendem, supostamente, padecer dessa enfermidade? A partir de que critérios levantam tal hipótese?

Conforme será apresentado no próximo item, apesar de a maioria das professoras serem contundentes em suas críticas à banalização desse diagnóstico, notamos contradições em suas falas, pois muitas identificam a presença do transtorno em um ou mais de seus alunos e realizam encaminhamentos partindo dessa suspeita.

São crianças diferentes das só agitadas, é uma coisa incontrolável. São muito impulsivos, muito mais do que aqueles que são agitados e, quando você pede, eles param. Esses não.

\footnotetext{
${ }^{38}$ A escolha do verbo vender não é aleatória, mas sim proposital. Pois é por meio de um mercado de saber (cursos, congressos, manuais, etc) e de drogas psicotrópicas que incitam ao consumo que o discurso científico vende a ilusão de que é sim possível eliminar completamente os conflitos e atingir a felicidade plena. Sobre este assunto, recomendamos a leitura de "Por que a Psicanálise", obra fundamental da psicanalista Elizabeth Roudinesco (2000).
} 
Alguns que eu suspeito que tenham algum transtorno. Esses que são muito fortes. Estes dois eu acho que eles têm um déficit de atenção, teria que se averiguar mais. E de hiperatividade eu tenho... é, acho que mais uns dois ali. O resto eu me questiono muito. (Juliana)

Diante da surpresa da entrevistadora, ao contrapor Juliana com a própria fala questionando como seria pensar que numa sala de 25 alunos haveria quatro com questões de ordem neurológica (de acordo com a sua compreensão sobre a causalidade do TDAH), obtivemos a seguinte resposta:

...neurológica, exatamente. Eu acho normal. Acho uma porcentagem grande, por isso que eu acho que os professores têm que saber mais desses assuntos. Para agir de forma mais adequada. Saber do assunto muda a prática, o olhar. Não é porque fulano é mal educado ou por causa da família, é uma dificuldade da criança mesmo, tem outra causa. Agora, cuidado para não generalizar e banalizar a coisa. Tem uns professores que "ah, todo mundo é hiperativo, todos tem déficit de atenção". E não é assim. Por isso, acho que o professor tem que ficar mais bem informado para não ficar generalizando demais, tem que fazer curso para saber o que fazer, se especializar e saber mais.

É notável como esta professora, que discursa em vários momentos ao longo da entrevista sobre uma preocupação com a banalização do diagnóstico de TDAH, paradoxalmente não se dá conta de que ela própria está, nitidamente, inserida nesta lógica medicalizante. Tomamos sua fala como um ato falho, que irrompe através deste dito e que diz respeito à expressão do sujeito do inconsciente.

Foi por intermédio dessas formações (atos falhos, lapsos, sintomas, sonhos) que Freud postulou, em sua Psicopatologia da Vida Cotidiana, que tudo aquilo que irrompe aponta para a existência de um outra cena, na qual habita um desejo não admitido pela consciência.

Além disso, a ideia de que o saber técnico orientaria o professor no sentido de saber exatamente como lidar com as crianças diagnosticadas com TDAH nos mostra novamente o atravessamento e a permeabilidade da escola ao discurso médico hegemônico, que engendra o discurso do especialista. A lógica das especialidades pretende afirmar que professor capacitado é sinônimo de professor especialista em técnicas de trabalho e que quanto maior o saber mais será possível controlar o comportamento da criança e evitar tudo aquilo que escapa ao esperado.

Escolhemos este excerto para destacar isso, pois nele a professora ressalta a importância de os professores buscarem saberes sobre a especificidade das crianças para guiar as suas ações. Qual a possibilidade de existência de um saber sobre "A" criança agitada e desatenta? Além disso, que auxílio traria ao professor uma informação tão generalizante? Não acreditamos que o recurso a soluções prêt-à-porter possua qualquer vantagem. Levantamos 
aqui estas questões para instigar o leitor a nos acompanhar na análise das entrevistas e mais adiante refletiremos mais detidamente sobre este assunto.

Para enriquecer nossa discussão, faremos uma breve alusão ao viés totalitário da ciência, colocado em operação no discurso do capitalista, e aos efeitos disso na educação. A predominância desse discurso na contemporaneidade pode ser atestada pela proliferação de simpósios, eventos, congressos e cursos que têm o objetivo de instrumentalizar o professor a lidar com o TDAH. Na vigência desse discurso, o saber é transformado em mercadoria e o sujeito acredita que estar de posse dele propiciaria o domínio e o alcance dos resultados almejados.

A perspectiva capitalista pode ser vislumbrada na fala desta professora, que acredita que o mercado pode oferecer aquilo que fará com que os profissionais da educação saibam precisamente o que fazer. Lacan (1969-70/1992) refere-se a essa questão, ainda que articulada prioritariamente ao discurso do universitário ${ }^{39}$ dizendo ser "impossível deixar de obedecer ao mandamento que está aí, no lugar do que é verdade do discurso da ciência - Vai, continua. Não para. Continua a saber sempre mais" (p. 98).

No próximo fragmento, a professora relata seu entendimento sobre as características da criança com TDAH, segundo essa mesma lógica medicalizante.

Eu acho que, em média, pelo menos um aluno por sala a gente sempre tem com TDAH. A criança não se concentra, não presta atenção no que eu falo, não registra e precisa muito mais da minha intervenção... Tem uma agitação constante. Não conseguem permanecer por muito tempo escutando. Permanecem um tempo muito menor que os outros. A agitação normal, quando o professor se coloca dentro da sala e dá uma bronca, ela consegue se controlar. A criança que estou te descrevendo com problema é uma criança que não consegue se controlar mesmo. (Meri)

Como discutido na parte teórica do trabalho, vemos atualmente a predominância de uma leitura dos sofrimentos psíquicos a partir de uma base biológica, revelada pelo grande número de diagnósticos psiquiátricos dentro das escolas. Nas entrevistas aqui apresentadas, encontramos referências a esta compreensão médica que situa os alunos entre portadores de transtornos. Verificamos, assim, que essa amostra evidencia como de fato o campo educativo está invadido de forma marcante pelo discurso psiquiátrico sobre as "disfunções" comportamentais e os sofrimentos das crianças. Os excertos acima destacados mostram o abuso da nomeação do diagnóstico de TDAH diante da observação de certos

\footnotetext{
${ }^{39}$ No discurso do universitário, o saber tem lugar dominante, ocupa o lugar da ordem outrora ocupado pelo mestre. O mestre não está mais na posição de domínio e em seu lugar permanece o imperativo categórico de saber sempre mais.
} 
comportamentos, indicando aquilo que Guarido (2007) entendeu ser uma "psiquiatrização do discurso escolar" (p. 158). Segundo a crença contemporânea baseada no discurso científico, "tudo no psiquismo pode ser reduzido ao substrato orgânico e a alma talvez não seja mais do que algumas secreções químicas" (Voltolini, 2012, p. 110).

As vinhetas a seguir mostram algumas palavras e expressões que as professoras entrevistadas empregam para justificar a categorização de uma criança sob o diagnóstico de TDAH. Diversas falas, salientadas aqui em negrito, referem-se à questão do autocontrole, como se a criança fosse "possuída" e não conseguisse dominar seu corpo.

Eu acho assim... Ficou meio banalizado, tudo é TDAH, qualquer coisa é TDAH. São casos que fogem do extremo assim, então, sobe pela parede, crianças muito agitadas mesmo, que você vê que independente da vontade não conseguem realmente se controlar e sofrem com aquilo... Foge da curva, destoa do grupo. É aquele que, quando você dá uma dura, todo mundo para e respeita e ele não consegue. Ele não controla, age por impulsos. A criança agitada, você puxa a rédea ela responde, ela consegue. O hiperativo não. (Roberta)

Com a hiperatividade a criança fica muito agitada, ela tem trejeitos, ela tem reações. Você fala olha, relê essa questão e a criança não dá conta. É uma criança angustiada, insegura, é uma criança que não dá conta, ela não consegue ler as propostas. Ela tem capacidade, é inteligente, mas não consegue. Tem uma ansiedade interna muito forte, ele percebe que fica dificil e cansa, não aguenta, porque ele é impaciente, ansioso. Tem uma criança que com três anos eu já achava que tinha déficit, porque ela tinha essa vontade de fazer algo, mas não durava cinco minutos e ele rabiscava tudo depois. Agora com quatro anos ele foi diagnosticado. (Débora)

Essa criança chama a atenção do professor porque não consegue se aquietar. Tem traços dela, na postura dela que não permitem. É uma falta de atenção, porque não conseguem ter um ponto fixo de concentração. Diferente das outras, diante de uma intervenção não consegue ficar quieta na carteira, não consegue guardar o material, se movimenta o tempo todo, precisa o tempo todo da ajuda do professor para se organizar. Fala o tempo todo, não espera o tempo certo, fala junto comigo. Não é só falta de educação. Eu percebo que ele não consegue mesmo com as minhas intervençães, mesmo com consequências. Constantemente tem essa agitação, constantemente desatenta, constantemente não ouve o outro. (Meri)

O transtorno, eu penso é algo que extrapola e não controla. Não é agitação só por agitação, da faixa etária da criança saudável e ativa e não é o desatento normal da criança, que tem uma série de coisas para pensar, ainda mais nesse mundo com computador, brinquedos e filmes. (Rose)

Quando Roberta marca a diferença entre a criança agitada e a criança dita hiperativa, pensamos que em parte ela tem razão. Entretanto, a criança taxada de hiperativa não sofre necessariamente de um distúrbio orgânico que requer remédios para ser tratado. É possível que essa "hiperatividade" seja resultado de um conflito psíquico, configurando-se como um sintoma, uma construção do sujeito, e a "calma" reivindicada pela criança não deveria vir por 
intermédio de medicamentos, que iriam calar seu apelo ao outro, mas sim no ato de limite (recalcamento e castração) imposto pelos adultos que se encarregam de educá-la.

Sobre as afirmações categóricas das professoras a respeito de uma impossibilidade referente à determinada condição atribuída à criança, destacamos mais uma vez o poder das verdades professadas pelo outro na constituição do sujeito. Se partimos da crença de que a criança diagnosticada com TDAH não consegue se controlar, se estabelecemos um juízo como este a priori a respeito do futuro, é muito provável que isso venha de fato a se efetivar como uma verdade. A partir daí, o encontro entre professor e aluno passará a ser mediado por este significante, que remete a certezas e que traz consigo uma série de concepções do professor sobre as possibilidades e limitações do aluno. Ao identificar "O" hiperativo decorrência do que Lajonquiére (1999) identifica como a criação d'A criança - e destacar suas limitações, vemos que estas professoras se remetem a uma generalização da criança a partir de tal diagnóstico ou de um traço predominante de seu comportamento. Como consequência, desaparece a singularidade das crianças e ganha relevo o discurso sobre "O" TDAH. Esse aspecto, identificado no discurso destas professoras, vai ao encontro do que afirma Voltolini, quando diz que "A" criança não corresponde às crianças com as quais nos encontramos diariamente, ao contrário, nos afasta delas, uma vez que aumenta nossa ignorância sobre elas nos predispondo para o encontro com um objeto e não com um sujeito. Para construirmos "A" criança foi crucial o concurso da Ciência, escrita assim com maiúscula para indicar sua transformação num discurso mais do que em uma forma de saber entre outras ${ }^{40}$.

Ao operar com a redução e com uma tendência à homogeneização, vemos que os fragmentos acima destacados, ilustram essa disposição universalizante do discurso pedagógico, apoiado nos saberes produzidos pela ciência e que pretendem enunciar verdades absolutas sobre os sujeitos. "A definição d'A criança serve para fins sobretudo instrumentais... tudo que nela escapar ao controle tende a ser apagado, ou reinterpretado" segundo os imperativos da ciência, ressalta Voltolini ${ }^{41}$.

Outro aspecto encontrado com certa regularidade em alguns fragmentos refere-se ao quanto algumas professoras demonstram o que entendemos ser um certo incômodo e inquietação com a questão da TDAH, manifestando um estado de confusão.

Transtorno de déficit de atenção e ansiedade... não sei ao certo... Ah, me vem essa imagem de uma criança com dificuldade de se prender, de prestar atenção e de estar sempre ansioso

\footnotetext{
${ }^{40}$ Voltolini (comunicação pessoal, 8 de novembro de 2008, no $7^{\circ}$ Colóquio do Lepsi, IP/FE-USP, São Paulo)

${ }^{41}$ Idem
} 
querendo fazer outra coisa, sempre num movimento de ansiedade e atenção. Não presta atenção porque está prestando atenção em outra coisa e por estar ansioso não consegue se prender às coisas. Não sei direito. (Vera)

Fez um exame neurológico e detectou, eu acho, o déficit de atenção. Pode ser num exame neurológico? Teve algum exame que detectou que ela tinha que ser medicada. (Vera)

Eu acho que ainda tá muito confuso pra gente essa questão toda de como a gente lida. Não é uma coisa que é tranquila... acho que ainda é muito confuso para a gente, professor, saber dessas diferenças. "Ah, é o transtorno de... ah, é hiperatividade, é, dislexia." Sabe assim? As coisas ficam assim ainda muito confusas. (Ângela)

Chamou a nossa atenção a reflexão de Marta, pois tão logo começou a discorrer sobre o que entende ser as características comportamentais da criança com TDAH, frente à indagação da entrevistadora, ela se permitiu esboçar um questionamento.

Acho que é uma criança que tem uma atividade, agitação excessiva que o atrapalha nas relações sociais e no contato com a aprendizagem e não consegue manter a atenção por um tempo maior. Acho que deve ser isso... mas eu questiono... porque tem o F., que é muito inteligente, então, se ele é inteligente é porque consegue prestar atenção. No entanto, ele tem um diagnóstico de déficit de atenção. Eu me questiono. Mas é um diagnóstico médico, que foi dado por especialistas, né, psiquiatra e neurologista. E, no entanto, como ele consegue reter tanta coisa na cabeça se ele não tem atenção? Não é a atenção que a gente considera a normal. Mas eles que sabem. (Marta)

No entanto, a pregnância do discurso médico é tamanha que, mesmo perplexa ante o diagnóstico de um de seus alunos, esta professora acata e consente, pois concebe que o especialista é o detentor do saber e da verdade a respeito da criança.

A posição de Clara salienta uma compreensão que vai na contracorrente do que está posto no discurso (psico)pedagógico hegemônico, como vimos na literatura sobre o tema. Ela acredita que:

[É] muito difícil encontrar. Deve ser quando a coisa fica num extremo e que a família e a escola não conseguem lidar... Muitas vezes é uma questão familiar, um sintoma da família, então, vamos tratá-lo para encobrir o que tava acontecendo. Acho que é o que muitas vezes acontece. (Clara)

Do excerto destacado acima, podemos extrair mais um elemento que merece ser realçado, referente ao incômodo provocado pelos sintomas disruptivos. Vejamos abaixo alguns fragmentos discursivos que ilustram esta questão: 
Eu já conhecia ele na escola, já tinha ouvido comentários, porque sempre foi uma criança que incom... Sempre teve toda essa história. Já tinha escutado. (Vera)

É uma criança que tem essa queixa de desatenção, na maioria das vezes crianças que incomodam os professores. A criança que fica quietinha e não presta atenção, eu acho que essas crianças não chegam tanto aos consultórios... A criança atrapalha, você começa a falar ela te interrompe, não consegue esperar muito, a todo momento você fala o nome dela, $\mathrm{n}$ vezes por dia. O tempo todo você tem que apontar para a criança: "Olha os combinados". Então, dá muito trabalho. (Clara)

O TDAH, eu acredito que é desde pequeno que começa. A família começa a ficar incomodada pela agitação e não dá conta. (Juliana)

Por meio destas vinhetas, percebemos que o TDAH é primordialmente reconhecido por estas professoras, por meio dos comportamentos barulhentos das crianças, ou seja, pelo incômodo despertado. Assim como observam os autores que realizam uma análise crítica da psiquiatria contemporânea, notamos também aqui que é quando as crianças entram em conflito com as expectativas e demandas parentais e de seus professores que elas costumam ser identificadas como portadoras de TDAH. São aquelas crianças que causam perturbação na sala de aula, que contrariam regras e demandam bastante trabalho.

Novamente é a não correspondência ao ideal de aluno que justifica essa compreensão medicalizante, que atribui a responsabilidade à criança. $\mathrm{O}$ que está em jogo parece ser a tolerância e as exigências sociais, já que não existe uma fronteira clara entre a hiperatividade, a atividade mais intensa e a atividade dita "normal".

Tomemos como exemplo uma família da classe favorecida economicamente, cujos pais são profissionais bem-sucedidos. Espera-se que essa criança, que frequenta uma escola de elite, vá bem. No entanto, ela apresenta uma série de dificuldades de aprendizagem e de comportamento. Como pode essa criança, que tem acesso a todos os recursos (pensados em termos materiais), ir mal na escola? Este não esperado, medido por meio de valores silenciados, passa a ser "o agente secreto que maneja os fios dos critérios de medição dos transtornos, o critério decisivo para a avaliação da maior ou menor gravidade dos comportamentos agrupados em siglas" (Fendrik \& Jerusanlinsky, 2011, p. 33). Em vez de o professor tentar entender, por exemplo, por que o aluno está desobedecendo, o que o está deixando inquieto, o problema é rapidamente transposto para o cérebro alterado da criança.

O resultado, como sabemos, é a desresponsabilização dos adultos, a estigmatização da criança e a medicação como solução coercitiva ao conflito. Frente a isso, preocupamo-nos com aquelas crianças introvertidas e quietas e que podem estar sofrendo muito, mas 
passam muitas vezes despercebidas, pois não chamam a atenção dos professores, porque não incomodam nem importunam. Isso é apenas algo a ser anotado, mas que não será discutido aqui.

Somos todos TDAH?

A vulgarização do TDAH comparece não apenas no entendimento medicalizante que a maioria das professoras possui a respeito do comportamento dos alunos através de ditos e de não ditos, mas também em suas falas referentes àquilo que circula atualmente no discurso social. Apesar de verbalizarem uma leitura crítica sobre a proliferação de diagnósticos de TDAH na contemporaneidade, poucas professoras puderam se ver implicadas e imersas nessa mesma lógica. As próximas vinhetas revelam a percepção de tal banalização.

Hoje todo mundo é tachado de TDAH. Procurou o neuro, vai lá, é TDAH. Ritalina é dada como xarope... Eu acho que banaliza um pouco, tem que cuidar para não aumentar o número de diagnósticos à toa assim. Porque vai tachar todo mundo, tá com dificuldade na escola, vamos procurar e fazer um diagnóstico. (Roberta)

Os professores têm a tendência a diagnosticar, banalizar mesmo. Em sala de professores eu ouço: "Ah, ele é o doente". Cem por cento dos professores falam isso. Tem essa dificuldade de lidar com a criança inquieta. A familia e os outros professores sempre levantam a hipótese: "será que ele tem TDAH?". Acho que os professores devem pensar em estratégias. Se você vai para o neuro, você vai sair com alguma coisa.... Eu tenho um filho diagnosticado. Ele passou por oito neuros até eu aceitar que ele tinha o transtorno (...) Mas tem um monte de alunos agitados que as colegas ficam torcendo para eles tomarem Ritalina. (Rose)

Hoje em dia é um perigo. As pessoas estão generalizando tudo. Então, tudo é TDAH, ou tudo é TDA. Eu acho que são casos e casos. (Juliana)

Hoje isso tá assim: "Ah, é déficit de atenção, dá ritalina". A criança vai lá no médico uma, duas vezes, e é o déficit de atenção e tomam Ritalina que tá tudo bem. Eu tenho um pouco de preocupação. As coisas estão ficando muito... como vou dizer... o fácil acesso. (Vera)

Existem muitos diagnósticos que não são reais. Veem que a criança é agitada e pronto: é hiperativo. Diagnósticos a rodo. É muito mais fácil diagnosticar. (Débora)

Em outros fragmentos, as professoras fazem críticas às famílias, responsabilizando-as pelo aumento do número de diagnósticos de TDAH. Analisaremos essa questão mais adiante, porquanto nos limitaremos a apresentar os excertos que fazem referência a este assunto. 
Hoje em dia vejo famílias se preocupando demais e indo procurar alguma coisa por achar que isso vai resolver a situação da criança. (Ângela)

É muito comum a criança que não tem limite, que também é o perfil das famílias da nossa sociedade hoje, achar que as crianças que não têm limite têm déficit de atenção. E aí não dá conta desse aluno em sala de aula e ficam torcendo para que essas crianças se mediquem. (Rose)

Hoje, qualquer coisa vem mãe pra mim: "Porque minha filha é um pouco agitada, eu acho que ela é hiperativa". A filha que é um pouco desatenta, "ah, acho que é déficit de atenção". (Vera)

Tem muitas mães que vão por conta própria, porque acham que o filho tem alguma coisa e querem resolver o problema como se fosse uma coisa assim, "vamos solucionar logo isso". E muitas vezes os pais levam no neuro para ver se tem alguma coisa... Acho que existe muito um modismo de a criança sem limite, então, vamos encaminhá-la. E para os pais fica confortável também... E para muitos professores. (Clara)

Não acho que seja tanto quanto falam... Acho que banalizam muito. Vira moda, modismo. Ah, todo mundo é TDAH, todo mundo tem dislexia, porque fica mais fácil dar um nome e falar: “Olha, pronto...". Fica fácil pros próprios professores, para o próprio aluno e para a família dar um nome para a coisa. (Juliana)

Estas duas últimas vinhetas destacam o aspecto da desresponsabilização provocado pela patologização e medicalização da educação, tão disseminada atualmente. Frente ao diagnóstico de TDAH e às dificuldades escolares, a responsabilidade, outrora atribuída ao método de ensino inadequado ou à educação familiar imprópria, recai sobre o cérebro da criança, deixando todos desimplicados, como bem puderam analisar estas professoras.

Existem também situações em que as próprias crianças se colocam como "objeto da ciência", ou seja, elas assumem que estão doentes e usam a "doença" como "desculpa" para as dificuldades e para "obrigar" a professora a ser menos exigente. Não seria este o ganho secundário da doença, sobre o qual Freud nos adverte? A "salvação" se daria no sentido de a própria criança ter um argumento científico no qual se apoiar para explicar seu mau desempenho - e este não ser entendido, por exemplo, como preguiça, falta de vontade ou falta de empenho.

Façamos uma breve pausa aqui para a observação que se segue. Sabemos que as chamadas virtudes morais alteram-se profundamente ao longo do tempo. O ócio, que para gregos e romanos era tão valorizado, como condição para o exercício da política e do espírito, torna-se "vício da preguiça" do homem livre, ao passo que o trabalho surge como a grande virtude (Chauí, 2010, p. 449). Lutero já dissera que "mente desocupada, oficina do diabo". 
Em nossa época, o ócio está associado à preguiça, indolência e moleza, o que não acontecia em outras épocas. O próprio termo "escola" deriva, segundo Chauí (2010), “do termo grego scholé, que significa ócio. Logo, o ócio estava relacionado à possibilidade de conhecimento, ao passo que o trabalho era tido como uma pena e desonra reservada aos escravos" (Jorge \& Bastos, 2014, p. 23).

Sobre isso, indaga Chauí: "Quando e por que se passou ao elogio do trabalho como virtude e se viu no elogio do ócio o convite ao vício, impondo-se negá-lo pelo neg-ócio?” (Chauí, 1999, citada por Jorge \& Bastos, 2014, p. 23). Com isso, queremos apenas deixar para o leitor a questão de como o ócio, rejeitado e escondido atualmente, já foi outrora valorizado. Conforme a época, o sujeito é incitado a se posicionar de uma ou outra forma perante a sociedade.

Juliana considera que o diagnóstico é conveniente para o aluno, pois ele usa isso como muleta.

[Ele] usa isso como muleta, como bengala. Ah, mas não pode fazer isso comigo porque eu tenho aquilo... Usa o diagnóstico para justificar uma dificuldade, o que não é correto e vai atrapalhar, na verdade.(Juliana)

Tem criança que se esconde atrás disso. Então diz: "Você não precisa exigir tanto de mim, porque minha mãe descobriu que eu tenho uma coisa ai". (Clara)

Tem criança que se coloca atrás de um diagnóstico e diz: "Olha aqui, eu sou disléxico, ta, não consigo fazer. Ah, agora eu vou ter mais tempo para fazer a prova". (Roberta)

Semelhantes a esses fragmentos anteriores, a seguir as professoras expõem o mesmo contexto salientando o papel das famílias na manutenção desta lógica.

Tem família que fala: "Ele tem o diagnóstico" e aí cruza os braços, esperando da escola... os beneficios. "Pronto, já fiz o que precisava" e ficam esperando. (Ângela)

Às vezes, são os pais que vão atrás do neuro para conseguir o diagnóstico e levar na escola. A escola nem pediu nem, assim, falou nada e eles já querem resolver. (Marta)

Nas escolas de elite estudadas, vimos como as famílias muitas vezes buscam o diagnóstico de TDAH para "justificar" o impasse escolar enfrentado pela criança, mesmo que tal diagnóstico tenha que ser comprado. Este é um exemplo da época em que vivemos, marcada pelo capitalismo desenfreado, onde tudo tem seu preço, tudo pode ser comprado. 
Se você não pega um profissional muito bom, ele pode dar o diagnóstico de TDAH porque a familia vê que o filho tá indo mal na escola e tem família que vai lá, eu já vi casos assim. $O$ (...) é uma escola elitizada, eu já vi casos onde o dinheiro rola solto. Então, ela paga. Está indo mal na escola, e com os beneficios que tem o TDAH, "meu filho agora é desatento, é isso, é aquilo". Eu já vi família que diz: "Então, ele tem déficit de atenção". Chegou o diagnóstico, pronto, ele vai receber os beneficios. Eu já vi várias famílias fazerem isso. "Aqui tá o diagnóstico, pronto, agora ele não pode mais vir com nota vermelha”. (Debora)

Interessante notar ainda como muitas professoras, ao discursarem sobre o que entendem ser a banalização do diagnóstico, remetem-se à própria infância. Sabemos que a criança interpela a todo o momento o adulto em sua própria infância. Algumas pessoas se pegam como ponto de referência, o que pode tanto facilitar quanto atrapalhar ou até abrir espaço para pensar de um modo diferente. A seguir serão trazidos alguns fragmentos que revelam as associações livres despertadas nas entrevistadas pela lembrança da criança e da aluna que foram.

Hoje em dia eu percebo muito na escola e nas falas das pessoas, eu acho que as coisas estão muito mais popularizadas. Tudo é déficit de atenção, tudo é bullying, tudo é algum transtorno, e isso me preocupa. Porque na minha época... Porque eu, por exemplo, era aluna, devia ter várias crianças com dificuldade de atenção, e nunca era... não entrava onde a gente entra hoje. Não lembro desse diagnóstico. Nossa, gente eu já fui chamada de tanta coisa quando era pequena. (Vera)

Quando eu era aluna, não se falava disso. Eu tinha amigas que falavam muito, eu mesma era supertagarela, e a professora vivia chamando minha atenção. Também não parava quieta. Mas antes não tinha isso de diagnóstico, eram alunos dificeis e agitados só. (Marta)

É um número muito grande, por isso que eu duvido do diagnóstico e do medicamento, porque eu tomo por base a minha experiência como aluna, né? Na sala onde eu estudei a gente nunca teve isso, nunca ouvi falar quando era aluna. Sempre teve alunos agitados, que chamavam a atenção por comportamento e levavam bronca. Eu mesma sempre fui assim, falava muito na aula, levava bronca e tinha minhas consequências. Eu não lembro de ter amigo tomando remédio. Eu acho que as crianças tinham que se adaptar ao sistema, ao formato da escola e pronto. (Meri)

Tendo visto que o diagnóstico de TDAH baseia-se, fundamentalmente, em critérios subjetivos, a partir dos quais o adulto interpretará o comportamento "esperado" ou "não esperado" da criança, vemos aqui a importância e o peso deste modelo de referência que o adulto toma para si a partir de sua própria infância. Estas professoras que em diversos momentos da entrevista questionam o diagnóstico de TDAH provavelmente o façam partindo de suas próprias experiências quando alunas, uma vez que, como podemos observar nas falas supracitadas, consideravam-se agitadas e tagarelas e nem por isso foram diagnosticadas devido a esses comportamentos. 
Destacamos em negrito, no discurso de Meri, a frase em que ela sublinha o fato de que antes as crianças tinham que se adaptar. Sobre isso nos propomos a pensar no quanto, atualmente, tudo gira em torno de um imediatismo de gozo. É quase como se a criança não aceitasse e não pudesse ser contrariada, frustrada ou repreendida. Este mesmo aspecto pode ser verificado no próximo excerto:

Vejo uma dificuldade muito grande de lidar com as frustrações... Parece que o filho não pode levar uma bronca. Já teve mãe que veio falar: "Ele falou que você foi brava com ele ontem". E eu falo: "Fui mesmo, eu preciso ser brava às vezes, faz parte da vida". Mas as famílias não aceitam. (Clara)

Analisemos esta atual conjuntura tomando como pano de fundo o discurso do capitalista proposto por Lacan. Comecemos nos remetendo brevemente à condição básica da existência da civilização, que é o sacrifício de um gozo pleno, cujo emblema é o pai da horda primitiva - sobre o qual Freud (1913/1996) nos fala em Totem e Tabu ${ }^{42}$-, que goza de todas as mulheres sem restrições em prol do laço feito entre os irmãos sobre um gozo possível e restrito. A ameaça a esta mesma condição ocorre quando algum sujeito almeja um gozo todo. Pois é justamente sobre isso que repousa o que Lacan veio a chamar de discurso do capitalista, que, conforme vimos, incita o sujeito a uma posição de tudo gozar.

Há na contemporaneidade um imperativo de gozo que impele o sujeito numa demanda incessante de prazer, enquanto que toda tensão que venha a se interpor a esse projeto de satisfação plena visa ser eliminada, afastada e banida. Nessa perspectiva, a educação e a socialização, que implicam necessariamente na coibição dos excessos narcísicos, na renúncia para a construção do laço social e na submissão às regras coletivas, acabam inevitavelmente sofrendo consequências, uma vez que, como afirma Freud (1911/1996), "podemos descrever a educação como um incitamento à dominação do princípio do prazer e à sua substituição pelo princípio da realidade" (p. 242).

Além disso, os adultos encarregados de educar a criança, ao apelarem antes a um diagnóstico médico para descrever e nomear um impasse ao invés de insistirem em que a criança reconheça e aceite os limites e regras impostos pelo ambiente escolar, acabam como

\footnotetext{
${ }^{42}$ Neste trabalho, inspirado pela pesquisa antropológica evolucionista do fim do século XIX, Freud (1913) parte de um poderoso mito para tratar da implicação dos membros de uma sociedade no estabelecimento da Lei do incesto e na legitimação simbólica da autoridade. Sucintamente, este mito nos conta que o pai primevo detinha a posse de todas as mulheres enquanto que os outros viviam excluídos. Num certo dia, todos os filhos se rebelam, matam e devoram o cadáver do pai, o que põe fim a horda patriarcal e instaura a sociedade fraterna. Nenhum dos filhos ocupou o lugar do pai pois, como todos desejavam ter a posse das mulheres, tal qual o pai primevo tinha e por ser este um desejo impraticável devido a rivalidade - os irmãos instituem a lei contra o incesto abrindo mão das mulheres para poder viverem juntos.
} 
consequência alimentando essa lógica pregada pelo discurso do capitalista. O sujeito segue, assim, impelido ao gozo e resiste a "curvar-se" à lei e a abdicar de qualquer coisa que se interponha na busca de um prazer pleno.

Faremos uma pausa aqui para refletir sobre as regras impostas socialmente. Quais regras são imprescindíveis? Esse é o grande alvo da educação: tentar determinar precisamente e antecipadamente qual seria o melhor método, aquele que garantiria o controle dos resultados e o sucesso entendido a partir de uma sequência lógica matemática, na qual dois fatores associados sempre chegam a um mesmo resultado.

A Psicanálise, por sua vez, sabe da "delicada" função da educação que ao mesmo tempo deve frear as pulsões, direcionando-as para uma curiosidade intelectual e permitindo a manutenção do convívio civilizatório, sem com isso reprimir por demasiado e conduzir o sujeito a uma neurose que o obrigue a viver suas angústias com muito sofrimento. Essa "justa medida" não é algo que possa ser previsto e controlado, pois, como sabemos, tudo aquilo que se passa na relação com o outro é da ordem do inesperado.

Eu falo por mim, eu sempre fui uma criança que sempre teve muita dificuldade na escola, muita, mas eu sempre superei minhas dificuldades sem nunca ter sido tachada de nada. Não, ah, não se falava assim. (Roberta)

Frente à alegação esboçada na vinheta acima, a pesquisadora interrogou a professora sobre essas crianças, que em sua época de escola, enfrentavam dificuldades mas não eram diagnosticadas. Quem eram esses alunos? "Pois é, eram os maus alunos." E hoje em dia quem são os maus alunos? "Hoje não tem mais, hoje tem disléxico, hoje tem TDAHs (risos)". Encontramos com bastante regularidade associações semelhantes, nas quais as professoras evocam esse mesmo aspecto após a interpelação da pesquisadora. Isso nos sugere que entre estas professoras há uma crítica e uma inquietação, ainda que veladas, e uma hesitação sobre o que seria de fato esse diagnóstico que assola as crianças na atualidade.

Eu não lembro, naquela época não se falava disso. A gente tinha as crianças bagunceiras, o mau aluno... Então, eu não entendo porque antes não se falava. Antes era a criança desatenta, era a criança bagunceira, tinha outros nomes. A gente passou a falar sobre isso agora. Eu acho que... não sei também porque não sou especialista. Mas eu percebo que essa criança hoje tem dificuldade para se manter concentrada porque tem tantas coisas acontecendo ao mesmo tempo que fica difícil para ela manter. Parece que a atenção dela fica dividida em muitas faces. Ai ela tem dificuldade para se concentrar e estabelecer até o fim o que ela se propõe, e levanta várias vezes por isso. (Ângela) 
Antes não tinha diagnóstico. Tinha alunos dificeis, agitados, considerados maus alunos. (Marta)

Vemos na fala de Ângela que, apesar do embaraço provocado pelo questionamento da pesquisadora sobre quem eram esses alunos antigamente, que hoje muito provavelmente já estariam sendo medicados com Ritalina, ela ainda supõe que os especialistas detenham o saber sobre isso e que não caberia a ela, então, questionar.

Esse discurso representa bem o paradoxo do "sujeito dividido como produto da ciência... que acredita desacreditando na ciência" (Quinet, 2009, p. 21). Queremos com isso dizer que apesar de possuir suas dúvidas e interrogações o sujeito crê na verdade da ciência e a coloca como detentora de um saber completo sobre a experiência humana.

Mal-estar contemporâneo na educação e suas implicações

Os dados obtidos a partir das entrevistas nos servirão de base, aqui, para exemplificar um modo possível de verificar as consequências, na educação, de uma sociedade desbussolada, na qual os sujeitos encontram-se imersos na angústia e inseridos numa era do vazio (Forbes, 2012). Entendemos que os impasses pedagógicos contemporâneos, evidenciados pela alta incidência do diagnóstico de TDAH nas escolas, expõem um certo malestar enfrentado no campo pedagógico. Para tal reflexão, abordaremos alguns aspectos teóricos discutidos ao longo do trabalho e que nos auxiliarão neste percurso.

Conforme foi apontado pela maioria das professoras, atualmente as famílias estão com dificuldade para lidar com o comportamento das crianças e estabelecer limites. Tendo a Psicanálise como referencial teórico, entendemos que isso está relacionado ao declínio da imago paterna, da autoridade que coloca limites claros, tudo isso associado ao discurso do capitalista, que nega a castração e promove um empuxo ao gozo. Tudo pode! Goze... sempre. Presenciamos atualmente uma realidade na qual, frente às dificuldades inerentes à educação de qualquer criança, muitos pais abandonam aquelas que seriam tarefas de sua responsabilidade - delegam ou esperam que terceiros a realizem, afinal, são levados a acreditar que existem especialistas que teriam supostamente uma expertise no assunto - e entendem que a falta de limites da criança esteja relacionada a um transtorno psiquiátrico e não à falta de contornos que seriam promovidos pela castração, pela interdição, em última 
instância, pela própria inadimplência e omissão parental. As falas trazidas a seguir revelam a percepção generalizada das professoras acerca da falta de limites da criança.

Hoje a gente vê uma falta de limite grande, uma coisa das crianças não terem mesmo essa questão de regras. Então, chega na escola e não quer respeitar os combinados. (Clara)

É muito comum a criança que não tem limite, que também é o perfil das famílias da nossa sociedade hoje, achar que as crianças que não têm limite têm déficit de atenção. E aí não dá conta desse aluno em sala de aula e ficam torcendo para que essas crianças se mediquem. Tem essa dificuldade de lidar com a criança inquieta... A mãe quando procura o médico pode estar falando dela mesma, das coisas que ela não dá conta da relação com o filho. E aí o médico dá Ritalina. (Rose)

A mãe e a psicóloga decidiram que ela ia começar a tomar Ritalina, estava muito difícil para a mãe lidar. (Vera)

Aquele menino (diagnosticado com TDAH) tinha uma questão de limite mesmo, faltou ali uma questão de educação e de limite... Na verdade, é um comportamento péssimo, porque não teve educação, é uma questão de falta de educação. Não é questão médica nem terapêutica, e esse é o mais difícil. Você vê que não teve educação mesmo, não tem valor, não tem limite, não tem respeito com o outro. E isso é o mais difícil de lidar... É uma questão atual, eu vejo uma reclamação de educação mesmo, as famílias hoje delegam tudo para a escola. São coisas básicas, de cumprimentar o adulto, os professores, respeitar o servente. Parece que os pais esperam que a escola ensine isto... E a gente acaba tendo que fazer, né, porque se você não faz vai ter que conviver com um menino que está o tempo todo desrespeitando. (Marta)

Eu acho que hoje falta muito limite, as crianças não têm limite em casa. A gente trabalha hoje com outro tipo de criança, e eu acho que hoje elas estão sendo rotuladas por uma coisa que falta em casa mesmo. Falta pulso. (Roberta)

Não tem a ver com TDAH, tem a ver com limite. A criança não tem a vida organizada, não tem família organizada que tenha compromisso com essa criança. Foi criada pela babá. É colocado medo nela, tem medo de pernilongo. O pai renega o filho. E os comportamentos dele são para chamar a atenção dos pais. (Meri)

As professoras se queixam que as famílias estão delegando às escolas aspectos básicos da educação que deveriam ser tratados no ambiente privado do lar. Isso nos leva a um ponto relevante para nossa reflexão: por que atualmente muitos pais estão abdicando da educação de seus filhos? Parece que não suportam a ideia de terem que impor limites às crianças e que, frente a eles, haverá inevitavelmente conflito e recusa. Muitas famílias parecem não admitir que educar exige trabalho, constância e persistência.

A reflexão psicanalítica acerca do declínio da imago social do pai, ou seja, de sua função simbólica, nos permite compreender as queixas copiosamente presentes nos discursos de todas as professoras entrevistadas, com relação à percepção da falta, da fragilidade e do 
enfraquecimento de uma autoridade que imponha limites. Enquanto o prestígio do "pai" representava antigamente a adesão a uma tradição, a uma filiação simbólica, temos como consequência da crise da tradição deflagrada pelo enfraquecimento das figuras de autoridade na modernidade a falta de uma referência simbólica. A metáfora paterna, relacionada à interdição e interpretada por Lacan como Nome-do-Pai, vem perdendo a sua força, e a imagem do pai vem se tornando vaga e desacreditada. Como decorrência do atual estado das coisas, verificamos que as salas de aula refletem essa conjuntura, tal como apontam as professoras entrevistadas, envolvendo desautorização, questionamento de regras e desrespeito por parte dos alunos. Tendo em vista que a função paterna é "submeter o sujeito à lei na perspectiva da castração", fica evidente para nós o efeito produzido pelo esfacelamento e declínio da imago paterna (Pereira, 2008, p. 60).

Outra consequência da decadência da imago paterna é o individualismo exacerbado, que revela uma concepção de homem "autoengendrado" a partir de suas potencialidades e dons naturais e não mais referenciado a uma herança cultural, a uma precedência histórica (Lajonquiére, 1999). O sujeito moderno encontra-se sob o imperativo de abandonar a tradição mesma que o funda, à maneira emblemática de um self made man do mercado capitalista.

A questão da falta de um solo comum e do culto ao individualismo "representa uma tendência do empuxo ao narcisismo, enquanto enfatiza a relação do sujeito consigo mesmo" (Voltolini, 2011b, p. 42). O imperativo dos ideais narcísicos sob os quais a sociedade se organiza nos tempos atuais faz com que tudo o que dele se distancie seja segregado e excluído. Frente a essa lógica, não nos soa estranho a ampla divulgação e proclamação do diagnóstico de TDAH entre pais e professores para se referir ao comportamento "desajustado" da criança.

A fim de ampliar ainda mais essa discussão, refletiremos sobre as decorrências do discurso do capitalista, já que o individualismo não é senão um dos produtos deste discurso. $\mathrm{O}$ mal-estar da civilização atual dominada pela ciência, conforme discutido no Capítulo 3, é fruto do discurso capitalista, que não promove o laço social. O outro é abstraído, enquanto que a preocupação do sujeito é gozar e para isso se cerca de objetos do desejo oferecidos pela sociedade - os gadgets (engenhocas) sobre os quais Lacan nos fala. Frente a esse imediatismo do gozo, qualquer entrave e limite imposto pela castração (que vem do outro) é repelido e afastado. Nesse sentido, podemos articular tal conceito com o declínio da autoridade, bem como com os achados da pesquisa que refletem a dificuldade das professoras hoje em dia com a imposição de limites. 
Avançando em nossa reflexão, segundo essa perspectiva, numa sociedade regida pelo discurso do capitalista, a educação entra com seu valor de troca, inerente ao capitalismo. Assim, as perguntas que norteiam o sujeito balizam-se em: de que me serve isso? Para que eu preciso? Tais perguntas são sustentadas pela lógica de uma cultura hedonista que prima pelo prazer. O princípio do utilitarismo rege os sujeitos que se guiam na seguinte busca: o que eu ganho em troca?

O sujeito demanda as razões do que lhe é ensinado porque "tendo perdido o sentido que só a tradição e seu lastro simbólico poderiam conferir, divaga em busca de um sentido individual, utilitário: Professor, de que vai 'me' servir isto que estamos aprendendo?" (Voltolini, 2011a, p. 44). Entretanto, sabemos que "é a renúncia ao imediatismo do prazer que permite acessar o conhecimento" (Voltolini, 2012, p. 112). Partilhamos da hipótese, engendrada desde a Psicanálise, de que esse declínio do sentido do conhecimento passa pela lógica do discurso do capitalista. $\mathrm{O}$ desejo assolado por este mesmo discurso impede que o sujeito se lance nos caminhos da busca pelo conhecimento. Deixemos aqui apenas sublinhada essa questão que assola a educação contemporânea, que sofre da falta de referências simbólicas, alertando para o fato de que autoridade nenhuma é capaz de sustentar a degradação dos laços sociais produzida pelo discurso do capitalista.

Diante das considerações acima, constatamos as consequências na educação de um sujeito desbussolado, imerso no vazio e na falta de sentido atribuída ao conhecimento. Conforme vimos no Capítulo 3, a contemporaneidade sustenta a pluralização dos Nomes-doPai (frente ao declínio da unidade da função paterna) e produz o sujeito desbussolado como efeito.

\footnotetext{
Alijado do passado e da massa humana que o precede, fechado em seu próprio circuito e prometido a um desenvolvimento sem rumo, não é de se estranhar que o indivíduo esteja perdido, em busca de sentido. (Voltolini, 2011a, p. 42)
}

Outro efeito desse desbussolamento, tal como foi encontrado nas entrevistas, refere-se ao fato dos sujeitos não quererem se responsabilizar pelas suas escolhas. Como consequência, vemos algumas crianças se escondendo atrás de diagnósticos. Esse aspecto já foi interpretado em nossa análise das entrevistas, mas ainda assim vale a pena frisar novamente como algumas crianças usam o diagnóstico como "arma" para atingir seus objetivos e ter uma "desculpa" diante dos pais e professores para as suas dificuldades, sem ter que assumi-las em função de sua falta de empenho. 
Voltando para a análise das entrevistas e a articulação dos achados com o mal-estar contemporâneo na educação, exposto pelo número vertiginoso de diagnósticos de TDAH, seguimos com a apresentação de algumas vinhetas. Conforme veremos, entendemos que a idealização da criança é outro aspecto que impulsiona e justifica para muitos pais a busca pelo diagnóstico psiquiátrico.

A família encontra um nome para aquilo que o filho tem. A falha não é nossa, nós não erramos. Ele tem TDAH e está sendo medicado. A familia nos procura e fala: "Olha, encontramos o que ele tem!", achando que ai vão tratar e o filho volta a ser aquilo que eles esperam dele, que seria sem problemas e dificuldade. (Clara)

Os pais não aguentam. Eles chegam e falam: "Fui lá no neuro e deu mesmo uma questão na atenção". Eles querem muito uma justificativa, "por que o meu filho não aprende, por que o meu filho não está tão bem quanto eu acho que ele deveria estar?”. (Clara)

Hoje em dia eu vejo também famílias se preocupando demais e indo procurar alguma coisa e achar que isso vai resolver a situação da criança. Então, você tem os dois lados: às vezes, gente que não quer mexer nisso, porque deve ser dificil você ver que o seu filho tem questões que dão nisso, e tem outro que vão procurar e que a criança nem tem alguma questão que você chamaria pra falar. (Ângela)

Encontramos nestas vinhetas a referência à criança ideal, representada narcisicamente no imaginário dos pais. As narrativas destas professoras nos mostram como, de fato, muitas famílias optam pelo caminho "mais fácil" da medicação, pelo efeito rápido que ela produz sobre o comportamento da criança. Às vezes, a dificuldade dos próprios pais em suportar a angústia de ter um filho que não corresponde àquele imaginado e idealizado faz com que a medicalização ganhe tamanha força e repercussão. Para eles, muitas vezes é preferível um filho com TDAH do que ter que admitir que ele seja um mau aluno, pois com isso isentam-se de responsabilidade, já que entendem que o problema é um infortúnio localizado no cérebro da criança e que não lhes diz respeito. O filho com mau desempenho escolar pode ser motivo de vexame social, o que levaria muitas dessas famílias a pensar: O que os outros falarão de nós e de nosso filho? Como é possível isso na nossa família?

A Psicanálise, conforme discutido anteriormente, nos permite concluir sobre o reconhecimento da impossibilidade de a criança real ser igual a criança idealizada. Entretanto, o não reconhecimento dessa criança real acaba por validar e conduzir os adultos, feridos em seu narcisismo, por ações cujas consequências não podem ser dimensionadas.

O fragmento abaixo escancara uma realidade que pensamos ser própria a esta parcela da sociedade, cujos filhos estudam em escolas de elite, tal como apresentado no Capítulo 2. 
Para certos pais, o resultado escolar é valioso apenas para que a criança conclua a escolaridade obrigatória e, nesses casos, o rendimento acadêmico de fato tem pouca importância. Dentro desta lógica, o apelo aos laudos psicopedagógicos com suas explicações sobre o TDAH trazem apenas "certo sossego moral àquele que o recebe em mãos, que dessa forma pode continuar a fazer aquilo que já fazia" (Lajonquiére, 1999, p. 59). Apontamos aqui o engodo de tal lógica para assinalar as consequências embutidas nesta forma hegemônica de tratar as chamadas dificuldades escolares.

Já tive crianças medicadas com Ritalina, crianças de sete anos, porque a mãe queria que ele se concentrasse da uma as sete, então ele tomava Ritalina para isso... Eu acho que os pais querem dar para solucionar um problema perante a sociedade. "Meu filho tá bem, meu filho consegue acompanhar a escola e isso é que importa." E ai você tapa o sol com a peneira... Se ele tá com diagnóstico e tratamento, ele não tira nota abaixo da média. Ele nunca é um aluno ruim. (Débora)

Entretanto, não é em todas as famílias que o diagnóstico é encarado, a princípio, como solução para os problemas da criança. Como aponta esta professora, "tem pais que negam, que não querem fazer um tratamento e que não querem buscar ajuda, que não buscam o diagnóstico e dizem: 'meu filho não tem nada'”. Antes, porém, de concluir apressadamente que essas famílias possuem um entendimento crítico e se posicionam contra a patologização das questões escolares, seguimos ainda com a fala desta mesma professora, pois "quando eles veem que começa a aparecer nas notas, aí eles vão procurar ajuda”.

Logo, caímos na mesma lógica acima apresentada, pois mais importante que a presença ou não do diagnóstico é o sucesso escolar da criança. Para estas crianças, cujos pais pertencem à elite econômica, parece que os fins justificam os meios. Assim, para manter o status quo e garantir que a criança permaneça com seu grupo escolar, vale tudo, até a prescrição de drogas para manter a atenção e acalmar a agitação. Nesses casos, ainda que a ferida narcísica de ter que assumir que o filho sofre de um transtorno faça com que os pais neguem e rechacem o encaminhamento da escola, no fim, o sucesso escolar é que é privilegiado. Vale ressaltar que esse funcionamento que nos parece perverso é não só sustentado senão incentivado no interior das próprias escolas. A respeito disso, seguimos com a fala de Débora:

Se ela não tem o diagnóstico, você não tem nenhuma ação com ela. Ela é regular se não tem o diagnóstico. Ela vai ter que dar conta de tudo... E se os pais falam que o filho não tem nada, ele é regular. Mas ai ele vai começar a ir muito mal na escola, porque não dá conta, é muito para ele, precisa de ajuda... O professor vai buscando sempre provar para os pais que tem algo, que seu filho precisa de ajuda... A função do professor, eu acredito que é buscar cada 
vez mais provas para o pai dar um passo atrás e falar "ok, vou buscar ajuda". O mais difícil hoje é convencer o pai que o filho tem alguma coisa. (Débora)

Em outros fragmentos, as professoras versaram sobre aquilo que entendemos ser este mal-estar contemporâneo provocado pela medicalização da educação, evidenciado e posto em circulação no discurso social. Perante alguns questionamentos intencionais da pesquisadora, como, por exemplo, o que pensam a respeito de medicar crianças com TDAH, algumas professoras puderam re-elaborar seus discursos. Acreditamos que isso foi possível porque a pesquisa no campo da Psicanálise permite e propicia muitas vezes uma re-significação subjetiva, pois a todo o momento faz com que o sujeito se dê conta e se implique subjetivamente com o seu dito, e é isso o que anima esse tipo de pesquisa.

Eu percebo hoje em dia que tem uma cultura do remédio, então, realmente eu não sei isso de diag... O quanto essa criança é analisada até que esse remédio seja dado? Eu tenho um pouco de restrição com isso, tenho um certo medo, porque eu percebo que as crianças estão tomando cada vez mais esses medicamentos. (Meri)

Eu acho muito sério, tenho medo disso.... Acho que é um caminho mais fácil. Não acho que seja fácil para um pai bancar e falar "vou dar remédio para o meu filho", mas por outro lado parece que é uma mágica, né, um remedinho mágico que a criança vai ficar calma e tranquila. E eu acho que a gente, enquanto escola, pai, sociedade, acaba pagando um preço por isso. Porque a criança não fica ela de verdade. Mas sei lá se existem casos que a criança precisa tomar mesmo um remédio... Eu nunca vi nenhum. (Clara)

Ai, sinceramente eu não sei... Tenho uma sensação e acho difícil. Tenho questões com muitas coisas... Tenho um pouco de preocupação, porque eu acho que as coisas estão ficando muito... como vou dizer... é o fácil acesso. Será que tudo bem uma criança de oito anos ser medicada? Será que é por aí, começar com uma medicação? Tenho um pouco de receio, tá ficando uma coisa muito... e isso me incomoda. (Vera)

$\mathrm{Na}$ vinheta acima, a professora expõe uma postura crítica reflexiva e utiliza a expressão "fácil acesso", de acordo com a nossa compreensão, para se referir à predominância do discurso médico-científico a fim de explicar qualquer ocorrência do sujeito em termos de disfunções. Vale lembrar que a ciência no discurso do capitalista age transformando os medicamentos em objetos de consumo (gadgets) e produzindo novas categorias diagnósticas que seriam tratáveis pela utilização de tais remédios (Quinet, 2009). Assim, como já apontado no Capítulo 3, ao invés de novos remédios serem desenvolvidos para tratar os males, vemos que a ciência produz os "males", pseudonovos males, "para que sejam tratados por medicamentos que ela fabrica" (p. 22). Sobre isso, consideramos valioso, portanto, encontrar no discurso desta professora uma observação sobre a sua preocupação a respeito de como as 
pessoas vêm se apropriando em nossos dias do discurso da ciência e de sua evolução na psiquiatria.

A seguir, Rose evoca a vitimização que assola a sociedade para se referir àquilo que encontramos na literatura concernente a desresponsabilização provocada pela medicalização. Os sujeitos não se implicam com aquilo que acontece em suas vidas. Esta é uma característica da sociedade em que vivemos.

Estamos na era do sintético, do medicamento, da forminha. Não encaixou, você já é diferente. Há uma dificuldade da nossa sociedade em lidar com as diferenças. Nossa sociedade tem baixa tolerância. Você deve se encaixar em um perfil... A gente fica vitimizado... Talvez não seja a palavra, você fica refém dessa sociedade, do que se espera. (Rose)

Além disso, entendemos que o emprego do termo "refém" faz alusão novamente ao domínio exercido pela ideologia científica sobre o nosso corpo e psique, na direção de buscar tudo explicar, tudo entender e tudo remediar. Quando se está refém, significa que há um aprisionamento involuntário, onde o "refugiado" deve aceitar e obedecer incontestavelmente, caso contrário arcará com sérias consequências. Não há espaço para o sujeito, para o desejo. Fazendo um paralelo com a nossa pesquisa, podemos articular essa compreensão na referência que a professora faz ao tipo esperado e valorizado de indivíduo, sobre o qual todos os ideais são edificados e que justifica a exclusão e a falta de tolerância da sociedade.

Dentre as entrevistadas, uma professora, enquanto se referia ao TDAH e à agitação da criança, fez uma pausa em sua fala e apresentou uma inflexão em seu discurso, mostrando-se implicada como sujeito frente à atual compreensão organicista e medicalizante que domina a sociedade.

As crianças com TDAH são muito agitadas... Mas, na verdade... Acho que a escola colabora com isso. Eu também. Não só a escola, né, a sociedade, essa agitação toda e excesso de informação, excesso de tudo, eu acho que colabora para as crianças ficarem mais agitadas... (risos) Até a gente fica mais agitado com tudo isso. (Juliana)

Neste próximo excerto, a professora evoca as consequências do diagnóstico na vida da criança.

Diagnosticar uma criança é muito sério, né, no fim. Ela vai carregar isso para o resto da vida. Não podemos olhar e dizer: "É agitado, é a personalidade dele ser agitado". O que isso traz para mim? Interfere no aprendizado dele essa agitação? São tantas coisas para se pensar. (Débora) 
Tenho um filho com TDAH. Fui a oito neuropsicólogos até aceitar. Sempre desconfio do diagnóstico. Com TDAH vêm as comorbidades, TC, fono. Tenho aluno de oito anos que toma ansiolítico, Ritalina, Concerta. (Rose)

Chamou muito a nossa atenção o posicionamento distinto de Clara, que ao longo de toda a entrevista evidenciou uma postura crítica reflexiva sobre o TDAH. Destacou-se como a professora, entre todas as entrevistadas, foi a que mais vezes se referiu à medicalização na educação com preocupação. Em seus 20 anos de profissão, diz jamais ter cruzado com uma criança com TDAH, mas, alertada por aquilo que é divulgado pela mídia e pela ciência, acredita que deva existir, só acha que deve ser muito difícil encontrar, já que ela mesma nunca viu uma criança que padeça desse transtorno amplamente difundido na sociedade atual.

Parece que descobrimos a fórmula mágica. Eu acho perigoso, não acho que deva dar remédio para ninguém. Eu acho que deve existir casos... Mas muito poucas crianças com TDAH. Nunca vi. (Clara)

\section{Ritalina "Concerta"?}

Partimos da provocação do subtítulo acima, que brinca com o nome dos dois medicamentos mais utilizados no Brasil para o tratamento do TDAH, para analisar precisamente o que as professoras entrevistadas pensam a respeito da prescrição de psicofármacos para crianças diagnosticadas com esse transtorno. Quais seriam as decorrências de um discurso que traduz o comportamento inesperado do sujeito em termos biológicos, resultado de alterações cerebrais e passível de ser corrigido pelo uso de medicamentos.

Primeiramente, a maioria dos relatos sugere uma preocupação com os efeitos colaterais da medicação. Os efeitos adversos de apatia, letargia e inapetência são notados pela maioria das professoras com bastante preocupação, ainda quando apontam notar uma melhora no desempenho e postura do aluno em sala de aula.

Já tive aluno que tomava o remédio e aí me vinha uma sensação de apático demais com o remédio. (Ângela) 
Esse remédio mexe muito, tira a fome, então, eu não sei o quanto, para uma criança, tudo bem começar a tomar um remédio desse e que pode dar essas reações contrárias. (Vera)

Eu observo que ele come pouco. Vejo de efeito colateral do remédio a perda do apetite. (Roberta)

Ele passou a não comer, porque tira o apetite, a Ritalina. Ele passou a ficar mais aéreo, ele perdeu a personalidade dele... Teve alteração do comportamento. Acalmou como um calmante. (Débora)

A criança começou a tomar remédio e achei muito complicado, não sei se a dose estava errada e a criança ficou pra lá de agitada. Chegou a jogar um caderno em mim. (Clara)

Um aspecto curioso, como nos conta Rose, é que a criança "não toma o remédio nas férias nem nos finais de semana. Só para ir à escola”. Daí decorre o fato de a Ritalina ter sido apelidada popularmente pela mídia de "droga da obediência”, uma vez que ela exerce uma função de controle sobre o corpo do sujeito que, na maioria das vezes, torna-se apático. Importante dizer que essa contenção é sinal de toxicidade, ao acalmar a criança provocando um efeito zumbi. Sobre esse mesmo aspecto, vemos os seguintes excertos:

Ele toma de manhã para ficar bem para a aula de natação e nas outras atividades que faz de manhã e depois toma à tarde para vir à escola. O pai até brinca que precisaria sobrar um pouco para a noite, porque ele fica muito agitado. (Marta)

É um calmante. Ela acalma e se concentra mais, mas continua, né? Porque se parar a Ritalina, volta tudo. Ela não é um remédio que vai curar, não é curativo. Então, dá remédio. Acaba o ano e nas férias fica sem Ritalina e é ela mesma. Quer dizer, você não está fazendo um trabalho de resgate da criança confiar nela e evoluir. Você tá pensando no hoje e não no amanhã. (Débora)

Através da vinheta acima, a professora nos fala de uma restrição que possui em relação à Ritalina, pois a seu ver ela apenas encobre, maquia a situação, que volta a se apresentar tal como era tão logo o tratamento seja interrompido.

Ela toma o remédio para se controlar. Tem um resultado imediato. Talvez por isso os profissionais da área mediquem logo. A criança consegue se concentrar, fica mais calma. Só não sei quais as con... (Meri)

Tendo já discutido os valores propagados pela sociedade atual apoiada no discurso do capitalista, fica fácil compreender o porquê dessa busca ao subterfúgio da medicação, devido à rapidez dos resultados obtidos. Sabemos da existência de uma tentativa do ser humano de 
evitar viver a angústia. Muitos adultos encarregados de cuidar e de educar aqueles seres que chegam ao mundo depois de nós não suportam aguardar e não sustentam a posição de uma espera confiante, apostando que o sujeito possa dar conta dos impasses enfrentados. Por esse motivo recorrem prontamente aos medicamentos. Logo, o apelo aos remédios no mundo contemporâneo é a expressão direta de uma cultura que visa negar o mal-estar estrutural do sujeito, o qual, por ser estrutural, não pode ser negado.

A explicação aceita pelas professoras e que validaria o uso da Ritalina, apesar dos efeitos colaterais observados, vai na direção de um certo reducionismo ao biológico e de uma tradução da subjetividade em termos neuroquímicos, conforme sugerem as vinhetas a seguir.

Ao mesmo tempo eu perguntei para o médico o que acontece, por que ele não dá conta, e ele explicou que ele não produz os neurônios que correspondem à atenção. A medicação entra pra fazer essa função. Como o diabético precisa e o que tem problema no rim precisa tomar. Ele precisa tomar para dar conta disso. (Rose)

Uma vez fui no psiquiatra e ele me explicou de um jeito simples mas que esclareceu. Ele falou que o cérebro tem... ele envia essas substâncias que são os hormônios. Como chama mesmo a substância do bem-estar que se fala tanto? Serotonina. Isso, todas as ninas ai que o cérebro é responsável. Que o corpo normalmente tem que produzir isso. Quando a pessoa não produz tanto, ai vêm as questões da depressão, da fobia, do TDAH. O remédio atua nisso, pra ajudar essa substância a se produzir de um jeito artificial, com esse empurrãozinho do remédio. (Marta)

Esse tipo de compreensão, que vê a solução no uso de remédios, apoia-se no saber da ciência em sua dimensão técnica. A tomada do saber médico e do fenômeno subjetivo a partir do funcionamento orgânico confere à medicação o poder de regular a subjetividade. $\mathrm{Na}$ contramão de uma consideração sobre a complexidade subjetiva e a divisão do sujeito, o discurso médico atual faz parceria com a lógica de um capitalismo que idealiza o consumo como a fonte de uma satisfação irrestrita. O medicamento entra aqui como um bem a ser consumido. Frente às alterações nos neurotransmissores, a solução exata estaria nos remédios, que viriam ajustar essa desregulação.

A exaltação aos benefícios da Ritalina, a nosso ver, vem contribuindo crucialmente para o aumento do número de crianças diagnosticadas com TDAH e inclusive para a produção do aluno hiperativo e desatento. Ampliam-se os critérios e os sinais de identificação do transtorno e como consequência mais e mais pessoas se identificam e são identificadas com comportamentos que caracterizariam o TDAH.

No relato a seguir a professora questiona se os resultados se devem efetivamente à medicação. 
Ele tá muito melhor, mais fácil de lidar. Mas eu não sei se atribuo isso à medicação. Tenho feito tantas coisas também. E a terapia ajudou muito. (Meri)

Remetemo-nos a seguir, a um fragmento relativo ao "apoio químico" oferecido pelo medicamento. Entendemos que, mais que o efeito da droga sobre o cérebro, há um efeito subjetivo que não passa pela lógica consciente e que diz respeito à criança se sentir acolhida e ouvida em seu "sintoma", naquilo que expressa em seu comportamento. Como discutimos no Capítulo 3, de acordo com uma leitura psicanalítica o TDAH pode ser interpretado muitas vezes como um sintoma, ou seja, uma construção singular do sujeito com um pedido de ajuda endereçado ao outro. Daí, obviamente decorrem as consequências de buscar tratar isso, rapidamente, pela via da eliminação proposta pela administração de medicamentos, que visa obturar talvez a única saída encontrada pelo sujeito para dar conta de seu sofrimento.

Ao patologizar e medicalizar prontamente o que entendemos ser um sintoma manifesto pela criança, acaba-se roubando o tempo necessário para que ela possa elaborar e superar momentos de crise. Assim, as tentativas de cura por meio de psicofármacos correm o risco de atropelar o tempo psíquico que o sujeito necessita para recuperar sua capacidade de simbolização. Vale destacar aqui que o uso dos remédios no âmbito da escolarização como um recurso extra para garantir a aprendizagem possui efeitos que não são contabilizados quando opta-se por esta solução. Guarido (2008) adverte-nos sobre isso ao ressaltar:

Seus efeitos de subtração de: responsabilidade, de profundidade reflexiva e da dimensão simbólica das experiências humanas. Quando os remédios assumem a posição de serem instrumento para que o aprendizado ocorra, estamos novamente diante de uma perspectiva técnica, que reduz a potência do encontro humano como formativo, abrindo espaço, no campo da educação, pra que esta seja reduzida a uma técnica de estimulação das habilidades e competências. (p. 102)

Eu sou adepta da medicação em alguns casos. Eu acho que tem crianças aí que foge ao controle, que precisam às vezes de um apoio químico, né? (Roberta)

Paralelamente à sala de aula eu também sou professora particular e 90\% dos meus alunos são usuários de Ritalina. Então, o aluno que tá numa escola hoje e é diagnosticado, ele precisa sempre de um apoio a mais, porque a escola não dá conta de dar o suporte que esse aluno precisa. (Rose)

Novamente citamos o posicionamento crítico de Clara, que censura a utilização de psicofármacos para tratar o comportamento de crianças. Esperamos poder encontrar posturas semelhantes a essa entre cada vez mais professoras. 
Ele tomava o Concerta. Eu inclusive detesto o nome desse remédio, porque eu não acho que tem que consertar uma criança. E com o remédio era uma judiação: o menino dormia na sala de aula, ficava dopado. Tinha um efeito péssimo. Eu não acho que é bom para nenhuma criança. (Clara)

\section{Causalidade}

Os dados indicam que o entendimento a respeito do TDAH restringe-se à predominância de uma visão médico-organicista. O que mais nos chama a atenção é o fato de que as entrevistadas, quando perguntadas a respeito da compreensão que possuíam sobre o dito transtorno, respondiam que entendem como fator causador a realidade física e orgânica, o fato de que há algo que se passa no cérebro da criança. Segundo o referencial da psiquiatria biológica, partem do princípio de que há um substrato orgânico explicativo para a etiologia.

Do que vejo é uma criança que nasce com isso. É genético. (...) Eu acredito também. É desde pequeno que começa. (Juliana)

A causa da hiperatividade? Ah, eu acho que é físico, eu acho que é biológico. Eu entendo como um transtorno biológico mesmo. Não é... É o que eu te falei, eu vejo diferença entre falta de limites e o TDAH. Eu acho que são coisas diferentes. Um é biológico, e o outro é comportamental. Ainda que o biológico tenha efeitos comportamentais, né?

Na cabeça, primeiro, o que eu acho é orgânico, eu não sei dizer se é uma questão cerebral, né? Eu acho que é desorganizado, que ela não consegue centrar, e os estímulos viram muito mais intensos, porque não consegue controlar. (Roberta)

Causalidade... Acho que isso deve ser... genético talvez, não sei. Eu não sei de onde vem isso, mas acho que deve ser algum fator genético, de inquietação. (Meri)

Ainda que duas professoras levantem o aspecto emocional e afetivo, buscando articulá-lo ao comportamento descrito como desviante, elas não concebem que uma causalidade psíquica possa estar exclusivamente relacionada a isso. Por esse motivo, a maioria das professoras considera importante o diagnóstico médico e o tratamento psicopedagógico. Os fatores afetivos, quando elencados, são secundários. Mesmo quando alguma professora aparenta possuir termos de entendimento sobre o assunto, usando expressões como "angustiada" e "baixa autoestima", na verdade, ao longo da entrevista isso se revela de outra forma. As professoras, portanto, não se questionam se aquilo que observam como desviante no comportamento do aluno não seria um sintoma analítico. 
A causa, acho que seja emocional. Junto com alguma coisa no cérebro, questões nervosas. Não pode ser só emocional. É químico, né, uma coisa mais química, acho que pode ser sim uma coisa mais química. Como depressão, que tem causas emocionais e causas químicas, que não sei se uma leva a outra, eu acho que uma leva a outra, né? (Marta)

Nos fragmentos a seguir, as professoras iniciam o relato buscando articular o comportamento desordenado da criança com a vivência familiar. No entanto, rapidamente abandonam o que imaginávamos ser uma consideração dos aspectos psíquicos inconscientes em prol de uma visão organicista.

Era uma criança que passou por muita coisa, uma mãe drogada, foi abandonada e já tava solta. Teve um histórico complicado, de autoconfiança. E acredito que isso leve a um déficit a um... Mas, na verdade, é porque é orgânico, né? Durante a gravidez ela se alimentou disso. Já nasceu com isso. (Débora)

Talvez a rotina dessa criança prejudique também, pode ter um fator ai da dinâmica da familia que resulta nisso... Mas acho que deve ter algo a mais, porque outras crianças, mesmo com muitas atividades e, às vezes, com uma rotina mais agitada, conseguem se concentrar, e essa criança não. Eu acho que deve ter algum fator genético. (Marta)

Conforme os achados generalizantes da literatura médica sobre o TDAH, as professoras parecem estar imersas num campo de dúvidas e contradições a respeito do que seria a criança com esse transtorno, mas, ainda assim, o discurso médico prevalece amplamente como um discurso esclarecedor. As interpelações da pesquisadora - destacadas em negrito nas próximas vinhetas, sendo que algumas serão repetidas para uma visualização mais clara - propiciaram momentos de suspensão no que parecia um discurso "pronto", encontrado na mídia leiga com informações sobre o TDAH. Entretanto, a permeabilidade ao discurso médico-científico é tamanha que as professoras não se autorizam questionar e duvidar daquilo que é defendido pelos ditos especialistas no assunto.

A causa?... Neurológica? ...

\section{Eu não sei. Quero saber o que você entende como causa.}

Ah, eu não sei, acho que o ambiente influencia tanto, pensar nos estímulos, eu imagino essas coisas como causa. Pensaria muito mais nos estímulos, nas situações que essa criança vive pra estar o tempo inteiro ansiosa, com essa dificuldade de atenção. Agora, a partir do momento que toma um remédio, eu imagino então que tenha alguma coisa. Alguma coisa neurológica... Tinha feito um exame neurológico, e acho que tinha detectado. O déficit de atenção. Pode ser num exame neurológico?(Vera)

Acho que uma área do cérebro funciona diferente. Foi o que o neuro me explicou. Acreditei no neuro e tive que aceitar. Tem uma região do cérebro pouco estimulada e a Ritalina age aí. (Rose) 
A causa, acho que seja emocional. Junto com alguma coisa no cérebro, questões nervosas. Não pode ser só emocional. É químico, né, uma coisa mais química, acho que pode ser sim uma coisa mais quimica. Como depressão, que tem causas emocionais e causas químicas, que não sei se uma leva a outra, eu acho que uma leva a outra, né? Uma vez fui no psiquiatra, $e$ ele me explicou de um jeito simples, mas que esclareceu. Ele falou que o cérebro tem... ele envia essas substâncias que são os hormônios. Como chama mesmo a substância do bemestar que se fala tanto? Serotonina. Isso, todas as ninas aí que o cérebro é responsável, que o corpo normalmente tem que produzir isso. Quando a pessoa não produz tanto, ai vêm as questões da depressão, da fobia, do TDAH. O remédio atua nisso, pra ajudar essa substância a se produzir de um jeito artificial, com esse empurrãozinho do remédio. Acho que o remédio ajuda nisso. A terapia também ajuda nisso, ele disse. Acho que uma coisa tá ligada à outra. Você poderia me responder, né?

\section{E você, concorda com isso?}

... Eu acho que o emocional vem em primeiro lugar, principalmente para uma criança. $O$ meio que ela vive influencia tanto, né? (Marta)

O TDAH é orgânico, é uma disfunção no cérebro, como falam os médicos.

Para você o TDAH está localizado no registro orgânico. E os aspectos emocionais? Haveria uma causa psíquica?

Então, eu acho... Depende do caso. Tem criança que é orgânico cerebral, e eu acho que deve ter criança... É difícil isso, né? (Débora)

É orgânico.

\section{Você não acha que tenha causalidade psíquica?}

... Não sei, não sei. Nenhum transtorno, a gente acaba. A gente contorna, a gente ajuda a criança a lidar com aquilo, a conviver com aquilo. Nenhum disléxico é ex-disléxico, mas ele aprende a criar estratégias para chegar lá.

Então o TDAH, ele vai carregar na vida?

Vai carregar. Vai carregar... Vai? Será?(Roberta)

A causa... Será que isso é...é genético? É orgânico? Eu acho que ainda tá muito confuso pra gente essa questão toda de como a gente lida. (Ângela)

A consequência de encarar o impasse escolar em decorrência de uma alteração orgânica acarreta a medicalização e lógicas simplistas de tratamento, como temos assinalado, as quais excluem a subjetividade daquele que enuncia por meio de seu comportamento um certo sofrimento e mal-estar. A tomada do discurso médico pela pedagogia pode ser testemunhada nos achados das entrevistas realizadas e nos mostra, então, segundo aponta Priszkulnik (2008), os efeitos de "um discurso científico sobre a doença compreendida como 
uma entidade nosológica que acomete o paciente... e não permite considerar o campo da subjetividade e a experiência subjetiva, enquanto experiência singular" (p. 2).

O tratamento proposto convoca o saber dos especialistas mais uma vez, e nele são depositadas as esperanças de resolução e dissolução do problema. Conforme aponta a passagem a seguir, percebemos como a professora se exime de responsabilidade frente à criança.

Tem um tratamento com o especialista. Precisa de todo o processo de tratamento, uma equipe. Ai vem o relatório do especialista e são eles que se responsabilizam pelo diagnóstico. Aí a gente trabalha com a criança sempre com as orientações, porque eles falam como trabalhar e o que fazer em cada caso. As orientações dos especialistas são fundamentais. (Débora)

Frente a essa concepção majoritariamente organicista, não nos soa estranho os tão comentados especialistas, para os quais essas crianças são encaminhadas, sejam eles neuropsicólogos, psiquiatras e psicopedagogos - estes últimos na proposição de um tratamento ortopédico, no sentido de uma reeducação psicopedagógica para fortalecer o ego.

Casos especificos de algum transtorno a gente encaminha para uma avaliação neuropsicológica. A avaliação neuropsicológica dá uma clareada. Ou um neuro, né? (Roberta)

O tratamento tem que ser com o especialista. Tem que procurar um neurologista, um psiquiatra para fazer os exames realmente. Um neuropsicólogo para saber se é mesmo um TDAH. Fazer todos os testes, né? E ai tem o tratamento certo. (Juliana)

Novamente, na vinheta acima destacada, observamos a presença da ilusão (psico)pedagógica de que o saber médico poderia identificar precisamente, por meio de um exame, aquilo que escapa no comportamento da criança e, a partir disso, recomendar o tratamento exato. A lógica das avaliações persegue a busca de certezas apoiada na crença de que é possível dar conta de exterminar o mal-estar estrutural e, portanto, as dificuldades na escola.

Imagem de criança

Embora apenas duas professoras tenham se referido diretamente à imagem de criança que possuem, optamos pela escolha dessa categoria de análise, pois acreditamos que a 
referência encontrada em ambos os discursos conjuga uma ideia que perpassa o imaginário de todos os adultos: a da criança inocente.

Como apresentamos no Capítulo 3, Freud, com a teoria da sexualidade infantil, desvendou a criança perverso-polimorfa, tendo abalado profundamente a ideia que se tinha das crianças como seres inocentes e ingênuos. No entanto, apesar dessa concepção ter sido desmistificada pelas descobertas do autor há mais de um século, persiste nos adultos o ideal da criança pura e inocente. Tomemos como exemplo os dois fragmentos abaixo, nos quais as professoras referem-se ao modo como a criança recebe os chamados benefícios provenientes do diagnóstico (vide que as interpelações estão destacadas em negrito).

No primeiro ano as coisas ainda são mais tranquilas, a meu ver, porque as crianças são mais ingênuas,(...) eles ainda não, não notam grandes diferenças. Então, essa terceira pessoa dentro da sala de aula, a gente não deixa eles perceberem, né? Não deixamos muito exposto, porque justamente... para não expor a criança.

\section{E você acredita que ele não perceba?}

Não percebe, ele é ingênuo, a mãe disse que o neuro falou que ele tem dois anos de atraso. Ele é ingênuo mesmo e não percebe. (Roberta)

Eu já tive aluno que não recebia bem ser diferenciado. Então, não queria receber os beneficios, porque queria ser igual a todos. Então, a gente combinava com a familia: "Olha, amanhã vai ter uma prova", então, a família tirava mais cedo ou ele faltava. Porque ai ele não percebia. E no dia seguinte fazia a outra avaliação.

\section{E você acha que ele de fato não sabia? Não falava com os amigos?}

Não, porque a diferença era porque ele faltou, então, agora vai fazer sozinho. (Débora)

Diferentemente de outros momentos da entrevista, em que percebemos que a interpelação da pesquisadora propiciou por vezes que as professoras revissem as suas colocações, aqui, parece-nos que nada foi mobilizado a partir disso. Há uma certeza inabalável na ingenuidade da criança, que permite que tais estratégias armadas no interior das escolas para garantir que a criança com TDAH passe de ano sejam sustentadas e apoiadas. Essa concepção de infância, portanto, é que faz com que o adulto acredite poder tapear e esconder a verdade da criança, na ilusão de que ela não percebe as reais intenções do outro.

Detenhamo-nos um pouco aqui para pensar nas ações conduzidas por esse entendimento. Um ponto interessante para reflexão nos faz pensar que os professores não levantam a hipótese de que a criança possa se fazer passar por hiperativa e desatenta. Desconsideram que essa imagem de ingênua e inocente possa inclusive ser encenada por 
ela, fingindo não notar aquilo que o adulto acredita esconder. O que ela obtém com isso? Segue eximida de responsabilidade e vitimizada pela própria condição da qual, acreditase, ela padece.

Certas crianças, na posição de doentes, não se incomodam ao serem identificadas com um diagnóstico e até gozam com essa situação, ao passo que outras, na mesma posição de doentes, se rebelam e, nesses casos, o diagnóstico acaba por agravar e acentuar ainda mais a agitação - que pode, inclusive, ser o único modo que a criança encontrou para se expressar subjetivamente. Porém, essas reflexões só serão possíveis se uma leitura diferente puder ser feita e se as respostas às indagações não forem buscadas unicamente no campo médico científico - para o qual alterações comportamentais $=$ alterações neuroquímicas no cérebro $\rightarrow$ terapêuticas medicamentosas.

Qual o lugar do diagnóstico? Diagnóstico para que(m)?

Tendo visto que as professoras entrevistadas dão conta de inventar modos singulares de lidar com a criança agitada e desatenta em sala de aula, independentemente da presença ou não de um diagnóstico de TDAH, perguntamos: afinal, qual seria, então, a importância dessa denominação? Em que altera, no cotidiano escolar, saber ou não se o comportamento, tido como inconveniente ou inesperado, deriva de um suposto transtorno psiquiátrico?

Para além das decorrências advindas desse tipo de nomeação, passando pela psiquiatrização do discurso escolar e por uma desresponsabilização generalizada, já tratadas ao longo da análise das entrevistas, interessa-nos, neste momento, discutir os efeitos da interpelação da pesquisadora ao propiciar uma possível retificação subjetiva na maioria das professoras. Acreditamos que isso foi possível devido ao referencial psicanalítico, que embasou não apenas a análise dos resultados, mas, principalmente, que guiou as entrevistas. Em virtude disso, a importância da escuta psicanalítica neste trabalho é que ela "implica o outro em uma confrontação com seu próprio dizer, contribui para que se instalem, no lugar de certezas, perguntas e questões referentes às interpretações que os professores dão às atitudes 'estranhas' de seus alunos" (Bastos, 2005, p.146). Tomemos os fragmentos a seguir como exemplo do que viemos a chamar de retificação subjetiva: 
Você me fez pensar... Pro professor não muda, né? E para mim? Porque a gente acaba nem... Eu acabo nem... Eu sei que tem. Fulano tem lá o diagnóstico, mas o que eu tenho que fazer para tornar o aprendizado dele, aqui na escola, uma coisa significativa pra ele e que isso não fique...? Porque eu me preocupo muito que fique, ah, o fulano nunca consegue, tá sempre, sabe sempre o bagunceiro que é assim mesmo. Eu acho que isso é complicado no grupo e tem uma linha muito tênue para deixar a criança marcada. (Ângela)

A agitação é a mesma. Não mudaria então, né? Muda que aquele tem a justificativa científica e o outro não. Tem que trabalhar de qualquer forma. O com TDAH é o doente, e o outro é o sem educação. O professor determina muitas coisas com uma frase. Tem uma grande responsabilidade e em sala de professores eu ouço: "Ah, ele é o doente". Cem por cento dos professores falam isso. (Rose)

Isso que você tá falando... De repente, o que mudaria ou não? É bem isso: eu acho que é só se tivesse orientações, se você chegasse com orientações. Uma criança com déficit de atenção é seríssimo e tem que ter tais orientações. Então seria bom eu saber. Agora, se uma criança com déficit de atenção é uma criança com dificuldade de atenção como eu vejo, ai é do professor sentir e saber como lidar com essa criança. E pensar nas estratégias com o déficit de atenção, com a hiperatividade, com a falta de educação que não tem nenhuma patologia e você tem que saber fazer algo com essa criança. Não tinha parado para pensar nisso, mas é isso mesmo...

Agora já tô pensando diferente. Com você me perguntando o que mudaria, eu fiz uma coisinha aqui na minha cabeça. Já mudei uma coisa. Não mudaria, quer dizer, não mudaria a não ser que você me dissesse que tem certas orientações. Mas, aí, é como uma mãe que também chegaria e me contaria de orientações que é legal ter com o filho. É isso mesmo. Só que hoje em dia é tudo déficit de atenção, bullying. (Vera)

... Ah, entendi o que você falou.... Então, olhando para esse ponto, não tinha pensado. Só se existisse alguma orientação mesmo... Olha, criança hiperativa tem que fazer tal coisa. Então, acho que não precisaria mesmo saber mesmo. Achei bem interessante isso, você me fez pensar. Porque é exatamente isso. Eu com os meus alunos, eu tento olhar um pouquinho o que cada um pode me dar. Um pouquinho do que cada um tem. Então, não adianta eu pedir para um aluno... Tem um que é mais agitado e tem que sair mais um pouco, tem que ir no banheiro mais vezes que o outro, tem que dar uma corrida, eu deixo. Então, se eu tivesse um aluno hiperativo, não sei que ele é hiperativo, mas eu sei que ele é muito agitado. Meu olhar seria: "Nossa, essa criança é agitada". Eu ia também tratar do mesmo jeito do agitado. (Meri)

Por intermédio dos excertos acima, verificamos que apesar de as professoras se darem conta de que para a prática educativa a simples nomeação do diagnóstico em nada interfere ou facilita, persiste uma ilusão de que isso poderia ser importante na elucidação de práticas e orientações a serem tomadas com essas crianças agitadas e desatentas e de que isso asseguraria o controle da situação. As professoras buscam, portanto, aplacar a angústia e, para tanto, perseguem respostas seguras. Percebemos, assim, que o discurso médico-científico, com seus ideais de saberes e certezas sobre o comportamento humano, atravessa o discurso pedagógico e insiste em fazer-se presente apesar das próprias críticas e discernimentos que pudemos verificar na fala das professoras. $\mathrm{O}$ engodo proclamado pela mídia leiga que divulga 
os saberes da ciência e a suposta existência de uma medida exata para dar conta dos impasses na educação é, por razões óbvias, altamente atrativo e perseguido pela pedagogia.

A próxima vinheta expõe essa condição de assujeitamento ao saber dos especialistas e a consequente desautorização do ato educativo.

Eu acho que muda, porque se a criança tem um diagnóstico sério nessa área, eu espero que o profissional que a acompanha me passe algumas intervenções possiveis de serem feitas em sala de aula... Então, eu espero sim que esse profissional me passe algumas estratégias, o que deve ser feito, ele que sabe.

\section{E vamos supor que essa criança passe pela avaliação e nada seja diagnosticado.}

Aí eu como professora tenho que dar conta.

\section{Mas se for genético, você deixaria de ter que dar conta?}

Não, mas aí eu precisaria de uma formação maior nisso. Então, eu conto com uma conversa maior com esse profissional pra ele me ajudar em sala de aula. (Marta)

Seguindo com os demais relatos a respeito do diagnóstico, para que e para quem, temos os seguintes excertos:

Ter o diagnóstico desse aluno ou não? Eu acho que muda a forma como ele (professor) vai lidar com esse aluno. Porque ele sabendo que ele tem, ele vai, como te falei, usar de alguns recursos que, mesmo que ele não tenha feito a psicopedagogia, ele sabe que pode usar, porque esse aluno tem um transtorno, uma dificuldade, não é porque tem manha, frescura, $e$ esse ele sabe que não e ele pode estar usando esse recurso para ajudar na verdade. (Juliana)

Eu acho que hoje em dia você percebe que tem alguma coisa que é maior do que ele. Não que o diagnóstico mude alguma coisa pra gente, a gente não trata dele. Mas, sei lá, ele tem aquilo, você sabe que ele precisa de uma atenção especial ali pra conseguir e mostrar o que ele é capaz... Eu acho assim, eu fiquei pensando. Há um tempo atrás, essas crianças, quando a gente tinha um aluno assim, ficava sempre aquele rótulo de uma criança que é assim mesmo, desde pequeno é desatento, como se fosse uma coisa voluntária. "Ele faz isso, porque é bagunceiro", porque era uma coisa que a criança, por características, não conseguia ir bem na escola ou não conseguia estar sempre atento e se portar ou era sempre o bagunceiro por conta disso. Eu acho que hoje em dia a gente consegue entender que vai além daquilo se ele quer ou não quer. Há uma coisa que impossibilita, é tanta agitação ali que ele não controla e não consegue manter-se concentrado. Então, eu acho que tirou-se um pouco essa coisa de achar que era culpa. Agora ele é assim mesmo. (Ângela)

Acho que muda um pouco assim. Pelo menos você compreende um pouco melhor o porquê daquelas atitudes daquele aluno, pra você não ficar achando que é só porque não tá a fim mesmo, que não faz porque não quer. Acho que quando você compreende um pouco mais, você olha de outro jeito. (Marta) 
Muda porque tem mais tolerância, dá mais tempo para a prova, explico duas vezes. Há uma discriminação dentro da escola. (Rose)

O que muda é a relação, que fica diferente. Você vai cobrar de uma criança que não tem o diagnóstico muito mais, você vai cobrar que ela tenha um comportamento controlado. E a criança com o diagnóstico você sabe que ela não tem controle mesmo desses impulsos dela. (Débora)

As vinhetas acima destacadas nos sugerem pensar nas crianças que realmente enfrentam dificuldades de aprendizagem e são encaradas pelos professores como manhosas e preguiçosas. Será que nessas situações o diagnóstico médico não poderia inclusive ajudar de certa forma? A criança manhosa recebe castigos e intolerância do outro frente ao seu comportamento, ao passo que a criança tida como doente, mas com os mesmos comportamentos que a anterior, obtém, por sua vez, tolerância do outro, que enxerga sua dificuldade como uma impossibilidade de apresentar-se de outra forma.

Numa lógica como essa, ser doente é melhor e mais conveniente do que ser preguiçoso, pois a preguiça estaria associada a uma falta de caráter - antigamente já foi considerada doença dos escravos, como vimos em Scliar (2007). Ampliemos essa discussão pensando sobre quais são os problemas de caráter que entram na esfera da moral, na qual ter preguiça torna a criança culpada. Como essa criança, desta família, pode ter problemas de caráter?

Agora, com o diagnóstico, isso não se revela dessa forma, pois a criança tem uma doença! Muitas famílias nem questionam o aspecto genético da doença, ou seja, a herança genética, no sentido de pensar qual lado da família transmitiu isso. A herança genética só pode ser pensada dentro de uma genealogia: avós, pais, criança. Talvez, seja o individualismo, negando as gerações, que facilite nem pensar no "lado da família" e, ao invés disso, pensar apenas que está na criança. Será que, então, até nesse aspecto os pais não se abstêm de alguma responsabilidade? E talvez de culpa?

Arguida sobre a questão de como lidar com alunos que imponham as mesmas dificuldades para os professores embora não tenham o diagnóstico de TDAH - e, então, no que mudaria ter-se ou não um "nome" para essa agitação e desatenção, uma vez que o professor deve encontrar uma estratégia em sala de aula -, Juliana surpreende-se e responde:

Usa... é... tem que usar [estratégias] com todos. O que eu digo é que, na verdade, é assim que, se os professores pudessem lidar dessa forma com todos, se eles tivessem essa visão, não precisava nem ter o diagnostico, né? (risos). Funciona para todo mundo, funciona para os dois grupos. O diagnóstico, é preciso ter hoje em dia, porque as pessoas não sabem como lidar. (Juliana) 
Frente às perguntas sobre os benefícios decorrentes do diagnóstico, se este não ajudaria também as demais crianças e se as estratégias criadas pelas professoras não seriam vantajosas para todos os alunos, no sentido de favorecer a aprendizagem, Débora, que defende a importância de se ter um diagnóstico, produz uma inflexão em sua fala e faz a seguinte colocação:

Para todas... Mas acho que as com déficit de atenção precisam muito mais de ajuda... Mas as outras também precisam... todas precisam confiar... todas precisam ter esse resgate. (Débora)

A seguir, as professoras comentam sobre como os manejos que desenvolvem em sala de aula independem da notícia do diagnóstico.

Antes ela não tomava Ritalina. Por esse viés que você tava falando, se, por exemplo, eu não soubesse nada, como de fato no começo do ano eu não sabia e fiz mesmo assim um trabalho com ela... Sem saber "olha é um transtorno, tem dificuldade de atenção, tem que tomar remédio", eu falei: "Ela tem dificuldade de atenção". Eu tenho que fazer o que eu posso. (Vera)

Eu acho que mesmo não sabendo que o F. tinha, eu iria ter que agir dessa forma, porque o dia-a-dia ali, ou eu crio estratégias ou eu faço diferente ou eu enlouqueço e as outras crianças enlouquecem comigo. Eu acho que eu ia tentar as mesmas coisas. (Marta)

Outros relatos avançam ainda mais na consideração sobre valorização do diagnóstico na atualidade. Algumas professoras discorrem amplamente sobre o assunto, questionando os motivos da alta demanda e prevalência do TDAH no interior das escolas, como podemos comprovar nos excertos a seguir:

Eu acho que, na verdade, a gente tem que lidar com a criança na sala de aula, o objetivo da gente... Tá tudo bem, tem lá um diagnóstico, mas e na sala de aula? Porque é como se o diagnóstico... O que a gente vê, às vezes, a família fez ali um diagnóstico e pra ela isso aí basta. Só que, assim, na sala de aula eu acho que, assim, o diagnóstico vira um detalhe, porque o importante é você buscar maneiras de que ele consiga se desenvolver de uma maneira que ele possa aprender, participar do grupo, se sinta bem e atuante ali naquele grupo. Tudo bem ter o diagnóstico, tem, mas isso não vai mudar a questão daquele aluno, naquele grupo, naquela sala, com aquela professora. (Ângela)

Pra mim não tem necessidade, eu acho. Tem isso que você comentou... Não mudaria, porque eu já olhei antes para ela como uma criança com dificuldade de atenção. Se isso, a dificuldade de atenção que eu olhei e notei, não foi nem uma coisa que eu falo de dificuldade de atenção como uma patologia... E uma dificuldade de atenção é uma característica dela, ela tem um pouco mais de dificuldade de atenção. (Vera) 
Entretanto, vale ressaltar que, apesar do questionamento disseminado pela escuta e pelas colocações da pesquisadora frente à importância concedida pela professora ao diagnóstico de TDAH, duas delas parecem não se mobilizar com a interpelação realizada.

\begin{abstract}
A partir do momento que ela tem o diagnóstico... Se ela não tem o diagnóstico, você não tem nenhuma ação com ela. Ela é regular se ela não tem diagnóstico. Ela vai ter que dar conta de tudo. A partir do momento que vem um diagnóstico, esse aluno é avaliado de forma diferente. Ele não vai fazer uma prova. A gente faz uma prova diferente para ele... Ele nunca ia com uma nota abaixo da média. Por isso, é importante o diagnóstico. A criança com algum déficit, ela não tira nota vermelha, porque ela não pode ser reprovada com o diagnóstico de déficit de atenção. Ele nunca é um aluno ruim. (Débora)
\end{abstract}

Eu acho que o apoio que você tem dos profissionais, dos especialistas... Eu acredito muito no trabalho de parceria. Você tem um neuro que te fala, então é isso, a maneira, as defasagens dele são essas, o ponto estratégico é esse (...) Escola não faz trabalho sozinha e família não faz esco... trabalho sozinha. (Roberta)

Consideramos que a importância da Psicanálise reside na indagação que ela promove sobre as pretensas verdades cristalizadas e diagnósticos-rotuladores oferecidos pelo discurso científico hegemônico e em sua presença interrogativa no campo educativo. A Psicanálise pretende clarear o que revela o comportamento agitado e desatento para cada criança em particular, dentro de certa escola, numa dada sociedade e perante sua família. Partindo do princípio de que o sujeito está, por princípio, implicado em todo ato, ela considera fundamental criar condições para que ele se interrogue a respeito das causas desses episódios, pois o saber advindo desse processo pode produzir efeitos subjetivos (Lajonquiére, 1999).

Notavelmente, testemunhamos o discurso de Clara frente ao propósito do diagnóstico de TDAH dentro das escolas, o qual independe da interpelação da pesquisadora para revelar um entendimento crítico.

Sabe, o diagnóstico revela, assim, ah, só deu um nome para aquilo que a gente já sabia que existia. A gente já sabia que existia uma desatenção, e nós trabalhamos com essa criança tendo isso. Não muda saber. É só um nome (risos). Então, ah, deu alguma coisa no processamento auditivo, uma coisa que também aparece muito, né, esse processamento auditivo. A gente já sabia que pra essa criança é complicado entender ordens. Eu já sabia que tinha algo ali e agora só vem com um nome. Pra mim não muda a minha prática... Deu o nome para aquilo que a gente já sabia que existia. Gente, vai mudar, o nome? Eu acho que não. Não muda, porque é o nosso trabalho. A gente tem crianças diferentes, e é desafio do professor lidar com essas crianças, com essa diversidade e tentar ajudar cada um a caminhar no processo de aprendizagem. (Clara) 
Para ampliar a nossa discussão, remetemo-nos a afirmação de Infante (2011) para lembrar que "um diagnóstico não nos informa tão somente sobre uma doença supostamente dada na natureza: ele a produz. Aspecto sempre negligenciado pelo positivismo empedernido do saber médico" (p. 63). 


\section{CONSIDERAÇÕES FINAIS}

Este trabalho foi mobilizado, fundamentalmente, por um incômodo provocado pelo número enorme e crescente de crianças diagnosticadas com Transtorno de Déficit de Atenção e Hiperatividade (TDAH). A constatação, não apenas da quantidade de encaminhamentos que partem das escolas para os chamados especialistas, mas também da aderência social à compreensão médica patologizante sobre o comportamento das crianças, é sem dúvida alguma motivo para espanto e justifica nosso interesse pelo tema. Fomos conduzidos a investigar o que estaria se passando no campo educativo que tem levado muitos professores a levantar, tão facilmente, a hipótese de TDAH e encaminhar a queixa baseados nesta suposição. Debruçamo-nos para isso sobre a fala dos professores, protagonistas do campo educacional, para ouvir o que eles pensam sobre o TDAH, que sentidos e significações atribuem a esse suposto transtorno que tomou dimensões "assustadoras" na contemporaneidade.

Partimos da percepção de um ciclo repetitivo, no qual as escolas, confrontadas com as dificuldades das crianças, seja de aprendizagem seja de indisciplina, solicitam às famílias uma intervenção e encaminham o aluno na maior parte das vezes ao psiquiatra ou ao neurologista na espera confiante de uma intervenção eficaz. A prescrição de Ritalina é prática corrente suportada pela escola, visto que a medicação é administrada de acordo com o horário escolar. A partir de uma leitura cuidadosa e diversificada sobre o assunto, pudemos realizar a seguinte consideração: a escola se tornou o dispositivo que valida o saber médico.

Se atualmente o discurso médico-psiquiátrico converteu-se no principal dispositivo regulador do normal e do patológico na infância, isso se dá graças as instituições de assistência a infância - a família, a escola, o conselho tutelar, as clínicas privadas, as unidades de saúde - que demandam à medicina uma intervenção medicamentosa sobre a criança. (Kamers, 2013, p. 160)

A escolha da amostra desta pesquisa - professores de escolas particulares de "elite" de São Paulo - se deve a diversos aspectos, entre os quais, conforme apontado anteriormente, salientamos a falta de estudos ${ }^{43}$ dirigidos a este escopo, possivelmente devido às críticas feitas por aqueles que estudam as questões da escola pública brasileira e seu tão reconhecido fracasso. Haveria talvez um preconceito velado que de certa forma intimidaria estudos como

\footnotetext{
${ }^{43}$ No capítulo 2 citamos alguns pesquisadores que recentemente tomaram a escola de elite como temática
} específica de estudo. 
este. Nós, no entanto, acreditamos ser muito importante que trabalhos voltados para essas escolas se tornem mais presentes. Vemos que o fracasso escolar não ocorre exclusivamente nas escolas públicas, mas também nas escolas particulares, ainda que em número menos expressivo e subdimensionado, muito possivelmente pelo apoio externo com o qual as crianças podem contar e assim reverter os resultados negativos. As características singulares dessa parcela ínfima da sociedade têm muito a revelar sobre o modo como o fracasso escolar é entendido e manejado pelas escolas e pelas famílias desse grupo social favorecido economicamente. Por essa razão, prioritariamente, consideramos valioso pesquisar como a questão dos encaminhamentos e diagnósticos de TDAH está nessas escolas, para a partir daí pensar sobre certos tipos de funcionamento e certas tomadas de decisão.

A partir da análise dos dados obtidos na pesquisa de campo, foi-nos possível chegar a alguns resultados, talvez previstos, baseados em nossa revisão bibliográfica e estudo sobre o tema. Contudo, também chegamos a muitos resultados peculiares, que entendemos estarem relacionados em grande parte com a escolha dessa amostra específica que foi tomada para o propósito deste trabalho.

Tal como encontrado na literatura que aborda criticamente as questões decorrentes da medicalização da educação, em nossa pesquisa, observamos também que o entendimento a respeito do TDAH restringe-se à predominância de uma visão médico-organicista. O que mais nos chama a atenção é o fato de que as entrevistadas, quando perguntadas a respeito da compreensão que possuíam sobre o dito transtorno disseram entender como fator causador a realidade física e orgânica, que há algo que se passa no cérebro da criança. Os dados indicam que a causalidade psíquica não é sequer suposta por essas professoras. A dimensão da pregnância da denominação do diagnóstico de TDAH transformou-se no que poderíamos chamar de pão-nosso-de-cada-dia e já não nos surpreende tanto encontrar mais e mais casos de diagnósticos e encaminhamentos partindo desta suspeita desde o interior das escolas.

Outro aspecto presente copiosamente na fala das entrevistadas diz respeito à demanda incessante pelo saber dos chamados especialistas para a efetivação do ato educativo. A procura pelo curso de Psicopedagogia, unanimidade entre essas professoras, está assentada nessa busca por "ferramentas" 44 que estariam baseadas num saber sobre a criança. Essas profissionais partilham, assim, de um ideário social que possui enorme projeção em nossa época e que supõe os especialistas como detentores da chave e solução para todos os problemas. Creem que eles poderão lhes assegurar, precisamente, o que pode e deve ser feito

\footnotetext{
${ }^{44}$ Ressaltamos em itálico palavras e expressões utilizadas pelas professoras ao longo da entrevista e que enriquecem nossas colocações finais.
} 
em sala de aula e têm a ilusão de que o saber técnico as orientará a saber como lidar com as crianças diagnosticadas com TDAH.

Notamos entre as entrevistadas um apelo pelas nomeações diagnósticas, que as faz levantar a hipótese de que a criança sofre de um transtorno. Buscam nomear impasses e vicissitudes próprias ao processo de escolarização, como se isso fosse a solução a partir da qual se teria a fórmula perfeita para evitar a sua ocorrência. Isso evidencia aquilo que encontramos na literatura e apresentamos no Capítulo 1, referente à medicalização das questões escolares, à presença marcante do discurso médico tecnocientífico. Os efeitos da incidência deste último sobre o discurso pedagógico na contemporaneidade revela-se nessa imensa patologização, que provoca o silenciamento dos conflitos humanos, negando que eles sejam inerentes à constituição da subjetividade e ao encontro com o outro. A Psicanálise, por sua vez, como tanto enfatizamos, nos adverte sobre a impossibilidade de não haver descontinuidades, intercorrências e impasses no campo da educação, na vida.

Pudemos verificar que paira sobre o imaginário dessas professoras certa imagem de criança idealizada, a qual possivelmente ancore muitas suposições. Entretanto, as entrevistas nos revelaram que algumas professoras parecem discernir que, embora partilhem de um ideal de aluno comportado, quieto e atento, na prática as coisas não funcionam assim e aquele aluno agitado, que aparenta estar disperso e distraído está, na verdade, atento a tudo aquilo que se passa ao seu redor. Basta para isso pensar nos "nativos digitais", que, como vimos, conseguem fazer com sucesso várias coisas ao mesmo tempo: ouvir música, assistir TV, falar ao celular e ainda fazer pesquisa na internet. Ainda que algumas professoras se refiram, por exemplo, a uma agitação "dentro do esperado", denotando a existência de um ideal ou padrão de agitação a partir do qual levantariam a hipótese do transtorno, pareceu-nos que a maioria delas está alertada sobre suas idealizações.

Procurar ter uma conversa, não de ficar toda hora chamando a criança e expondo, isso, eu percebi que começa a gerar mais agitação ainda. Então, é estar sempre mais próximo, e falando mais baixo... E procurar acho que, se eu vejo que ela terminou a atividade, então, pega um livro pra ler... Porque, por exemplo, eu tenho uma criança que é bem agitada, mas se ela termina e pega um livro, ela fica ali um tempo lendo o livro e ela gosta. (Ângela)

Utilizamos o excerto acima como exemplo de uma professora que respeita o ritmo diferente de cada aluno e não trata todas as crianças como "a criança anônima" e universal preconizada pelo discurso pedagógico, apoiado nos saberes produzidos pela tecnociência ao pretender enunciar verdades absolutas sobre os sujeitos. 
Observamos também que todas as professoras se referiram à agitação como uma inquietação, ao mesmo tempo em que disseram que hoje em dia as salas de aula estão, em geral, mais agitadas. Pensamos ser importante precisar isto para pensar na sociedade hipermoderna na qual vivemos, onde o efêmero, o imediato e o excessivo predominam, e os efeitos disto sobre o sujeito, tal como discutido no Capítulo 3. Como algumas professoras puderam perceber, as crianças "pedem" espaço para se movimentar, precisam dar vazão à "energia vital excedente", que cada vez mais é aprisionada em cadeiras por longas jornadas escolares. Há uma disparidade entre um corpo que é contido e exigido em seus aspectos cognitivos e uma infância que, como sabemos, está mergulhada constantemente num excesso de informações e de estímulos digitais. O brincar espontâneo está cada vez mais restrito, o horário para o recreio encurtou, e as aulas de Educação Física também foram cortadas. Será que as escolas não estariam promovendo e induzindo esses mesmos comportamentos sobre os quais se queixam? E ainda, não estariam as crianças, por meio dessa agitação, demandando uma divisão diferente do período que passam na escola para a realização de diversas tarefas? À escola caberia "escutar" as enunciações e refletir sobre as movimentações das crianças, concedendo um tempo um pouco maior ao brincar, o que possibilitaria à criança experienciar e descobrir o mundo através do entrelaçamento entre o seu desejo e o aprender. ${ }^{45}$

Isso nos remete à questão colocada por Cruz (2001): “Crianças desatentas ou crianças desatendidas?" (p. 204). Atualmente, conforme visto, as crianças acabam sendo atendidas como consumidores, com a oferta de uma infinidade de produtos que prometem o alcance da felicidade e o êxito escolar (entre os quais, os medicamentos), e, no entanto, são desatendidas por essa mesma sociedade, que não consegue reconhecer sua inquietude e movimentação, colocando-as como doenças. Algumas dessas professoras, marcadas pelos imperativos de produção, não param para pensar na relação entre uma sociedade inquietadora e a inquietude das crianças, as quais podem estar denunciando com seu comportamento algo sobre esse desencontro, sobre o mal-estar que enfrentam. Não concedem tempo à infância e desconsideram aquilo que é próprio a essa etapa da vida: as brincadeiras, as trocas sociais e os movimentos em direção ao outro.

Por esse motivo, convocamos a Psicanálise que, com seu saber, nos prova que os efeitos mais decisivos na história de um sujeito não são produtos de causas biológicas, pois "o corpo não é sua anatomia nem sua psicologia" (Fernandez, 2001, p. 206). Isso se articula aos

\footnotetext{
${ }^{45}$ Em países como a Suécia, a Itália e a França, que valorizam o brincar e possuem uma visão não medicalizante, a prevalência do TDAH é de $0.5 \%$ a $1 \%$, quando comparada a estatística americana que em 2011 afirmava ser entre 5\% a $13 \%$ (Lloyd, Stead \& Cohen, 2007).
} 
argumentos teóricos do discurso do capitalista de Lacan, apresentados no Capítulo 3, que avançou na discussão sobre a cultura, sobre a importância do social no sujeito, marcando-o.

Destacamos abaixo dois trechos das entrevistas, nos quais podemos perceber que as professoras se dão conta de que carregam em si um ideal compartilhado socialmente, ao mesmo tempo em que conseguem se descolar disso para enxergar a criança em sua singularidade.

Eu reparo muito que, às vezes, a gente tem um ranço da educação de que a criança agitada, ela tumultua, e a tendência do professor é sossegá-la. Mas esta criança é participativa do jeito dela e é extremamente produtiva. (Rose)

A gente tem um ranço muito forte de escola conservadora, que para aprender tem que ficar quieto, que para aprender tem que prestar atenção, que só aprende quem escreve direitinho. A gente carrega esse ranço. Eu mesma faço um esforço e acho que muitas situações eu consigo deixar de lado e ver que aquele menino está aprendendo mesmo que ele não entregue o trabalho como o outro. (Marta)

Sobre isso, destacamos o que consideramos ser o achado com maior destaque e relevância desta pesquisa, que diz respeito a inventividades das professoras no manejo dos impasses escolares com estratégias de enfrentamento que lhes são singulares. Para além da visão medicalizante observada com frequência e do recurso aos especialistas como donos da verdade, todas as professoras entrevistadas dão conta de desenvolver estratégias próprias para lidar com os alunos que se apresentam agitados e desatentos em sala de aula, independentemente da presença ou não do diagnóstico de TDAH. Percebem, por exemplo, crianças com ritmos mais rápidos e que precisam de "descargas motoras" mais frequentes, crianças que precisam estar sempre em alguma atividade, crianças que se beneficiam de uma leitura após o término de algum trabalho, entre outras.

Diversamente à paralisação sobre a qual lemos em alguns estudos sobre esta temática, com professores desorientados sobre o que fazer, encontramos em nossa pesquisa resultados que não coincidem (exatamente) com isso. Esperávamos que esse desbussolamento sobre o qual tanto se fala aparecesse generalizadamente também nos laços sociais das instituições educativas, com educadores não sabendo o que fazer nem como lidar com a criança que não se subordina à lei ou que é diagnosticada com TDAH. Entretanto, para a amostra de professoras que entrevistamos, vimos que isso não confere. As professoras entrevistadas dão conta de lidar com os impasses escolares em sala de aula - claro que não completamente - no encontro singular com cada criança e sobre o qual não se tem a priori qualquer receita ou fórmula mágica. Suas intervenções e invenções peculiares provêm de suas práticas, a partir 
das quais criam, dia após dia, algo que funcione para cada criança em particular. Não partem de uma receita que indica os ingredientes próprios necessários, uma medida padrão, e que num passo a passo garantiria o sucesso da receita. Advertidos pela Psicanálise, sabemos que isso não procede no campo da educação, onde lidamos com sujeitos e não com objetos distinção esta aparentemente simples e banal, mas sobre a qual nem sempre se está advertido. Assim como observa Bastos (2004), vemos que essas professoras "se veem lançadas a criar o próprio fazer pedagógico considerando o singular inevitável que as desafia em cada aluno" (p. 36).

Observamos, contudo, que persiste no imaginário das professoras a busca pela segurança de um diagnóstico e pela "receita" sobre formas pragmáticas de atuação para superar ou evitar o mal-estar na educação. Alimentam a ilusão de que os saberes psicopedagógicos poderiam lhes receitar o que deve ser feito em sala de aula. A aderência ao discurso médico-científico é tamanha que os professores têm dificuldade de se descolar disso para poder considerar sua prática singular, que não coincide com os tratados científicos sobre o assunto. Algumas das professoras entrevistadas respondem ao discurso do capitalista quando não contestam, não questionam, tampouco duvidam deste saber imposto como uma verdade inquestionável, mesmo quando sua prática parece dizer o contrário.

As professoras buscam, portanto, aplacar a angústia e para isso perseguem respostas seguras sobre como conduzir a tarefa educativa - ainda que o exercício da prática pedagógica lhes evidencie a inexistência de tal afiançamento. Por essa razão, se apegam ao discurso médico tecnocientífico com suas pretensas explicações universalizantes sobre tudo aquilo que se passa com o humano, visando identificar, medir, classificar e controlar. Parece que a essas professoras é difícil suportar não saber antecipadamente as estratégias que podem ser aplicadas em sala de aula frente a um comportamento disruptivo.

Percebemos que o discurso médico-científico, com seus ideais de saberes e certezas sobre o comportamento humano, atravessa o discurso dessas professoras e insiste em se fazer presente, apesar das próprias críticas e discernimentos que pudemos verificar na fala das próprias professoras. Um nítido exemplo disso encontra-se na vinheta abaixo:

Mas é um diagnóstico médico que foi dado por especialistas, né, psiquiatra e neurologista. E, no entanto, como ele consegue reter tanta coisa na cabeça se ele não tem atenção? Não é a atenção que a gente considera a normal. Mas eles que sabem. (Marta) 
Muitas professoras se referiram com hesitação ao diagnóstico de TDAH quando se puseram a pensar em quem eram essas crianças antigamente, no tempo em que elas eram alunas, com questões semelhantes de comportamento. Quem eram esses alunos?

Pois é, eram os maus alunos. E hoje em dia quem são os maus alunos? Hoje não tem mais, hoje tem disléxico, hoje tem TDAHs (risos). (Meri)

Observamos, portanto, que a despeito de possuírem um fazer criativo e se questionarem sobre o dito transtorno, essas professoras, em muitos momentos, se permitem ser expropriadas de seu saber, por privilegiar os conhecimentos especializados e o domínio das técnicas pelos especialistas.

Apesar de verbalizarem sobre uma banalização e vulgarização do diagnóstico de TDAH em nossa época, chamando a atenção para o "fácil acesso" e inclusive para lógicas funestas de mercado, nas quais tal diagnóstico é vendido às famílias por seus "benefícios", vemos que muitas professoras não se dão conta de que elas próprias estão imersas e respondem ao discurso dos especialistas. Como pode uma mesma professora fazer crítica à epidemia de sobrediagnóstico e de sobretratamento de TDAH e ao mesmo tempo identificar entre quatro de seus 25 alunos o transtorno? Pensaria ela ter tido o infortúnio do destino de ter reunido em sua sala quase $20 \%$ de crianças com problemas neurológicos? Como essa professora não se assombra com tamanha porcentagem? Retomamos aqui uma interrogação realizada durante a análise das entrevistas e sobre a qual nos propomos refletir agora, referente ao motivo do interesse e da insistência dos professores em identificar o transtorno. A serviço de que e de quem isso está posto? Em que sentido essa informação auxilia a práxis educativa e suas intervenções?

Para além dos fatores acima elencados, referentes ao interesse em evitar o mal-estar e tudo aquilo que fuja do esperado, acreditamos ser necessário ir mais além para discutir essa questão. Em primeiro lugar, destacamos a importância concedida ao diagnóstico pelas famílias e pela própria criança, que, conforme apontam as professoras, encontram uma explicação para o "ir mal na escola". Alunos justificam suas atitudes em referência ao diagnóstico, e o mesmo fazem as famílias, explicando-se perante a sociedade sobre o fracasso escolar de seu filho ou o comportamento inadequado, resultados de uma alteração neuroquímica e não de uma educação imprópria. Os efeitos disso, como sabemos, é uma desresponsabilização generalizada: ninguém tem nada a ver com isso, a culpa é do cérebro e 
de certos componentes seus que se encontram desajustados, ao que vem a tecnociência e o mercado de consumo com a oferta de uma resposta exata: Ritalina "Concerta".

Partimos, então, para o segundo ponto, considerado uma análise mais acurada/profunda sobre os motivos da busca incessante pelo diagnóstico médico, que acreditamos estar articulada àquilo exposto pela professora na vinheta abaixo:

A maioria dos professores sempre levantam a hipótese "será que ele tem TDAH?" Acho que os professores têm que pensar antes, porque se vai para o neuro, com certeza, vai sair com alguma coisa... O olhar do professor pode mudar muito. Você tem que esgotar todas as possibilidades para pensar em algo. Pode ser uma fábrica de gerar pacientes e você vê os neuro enriquecendo com tudo isso. (Rose)

Esta professora parte de uma percepção tantas vezes negligenciada e que explica muito o sucesso do qual goza a psiquiatria na contemporaneidade, que diz respeito aos interesses da indústria farmacêutica e à valorização do aspecto lucrativo em sua dimensão gananciosa. Sabemos, por certa literatura especializada de autores críticos, ainda em número reduzido, que certos psiquiatras, trabalhando junto a essas indústrias, realmente procuram "inventar" novas doenças para que determinados remédios tenham o consumo aumentado a fim de que os lucros dispararem ${ }^{46}$. Vemos a lógica do DSM agir em perfeita consonância com o progresso da indústria farmacológica, ligado à ampliação arbitrária do que se constitui como problema mental e a transformação de fases normais da vida em distúrbios mentais e da angústia cotidiana em problema de saúde mental. A lógica capitalista de mercado agencia esta epidemia de TDAH entre as crianças que assistimos na atualidade, visto que os lucros exorbitantes almejados, e alcançados pelas indústrias farmacêuticas, justificam o número cada vez maior de diagnósticos e, consequentemente, da venda de remédios para tratar o transtorno.

Para avançar na compreensão dos dados "epidêmicos" de prevalência do TDAH entre as crianças, convidamos ainda o leitor a nos acompanhar com o raciocínio que se segue. Sabemos que a educação e o estudo elevam o padrão dos países. Os fracassados escolares poderiam questionar as "sociedades desenvolvidas". Teriam todos as mesmas condições de estudar e ter êxito? As crianças com TDAH não ajudariam a desfocar as reflexões sobre as desigualdades sociais, cada vez mais pronunciadas? Sabemos que esse rótulo diagnóstico pode funcionar como um álibi na explicação do porquê de a escola regularmente falhar em

\footnotetext{
${ }^{46}$ A respeito do conflito de interesses ao qual estamos nos referindo, relembremos que dos 137 membros do painel do DSM-V, 56\% são psiquiatras que relatam ter vínculos financeiros com a indústria farmacêutica. Allen Frances, redator-chefe do DSM-IV, fez críticas severas sobre a nova versão do manual alertando para o poder do marketing da indústria farmacêutica, engendrando falsas epidemias e modismos em matéria de diagnósticos psiquiátricos e medicalizando a aflição cotidiana (St Onge, 2013).
} 
oferecer as condições necessárias que garantam o aprendizado dos alunos. As perguntas formuladas podem ser relativamente respondidas quando pensamos na análise depreendida por Werner (2001) a respeito da grande aceitação social dos diagnósticos e do papel regulador das explicações médicas nos EUA a partir da década de 60, numa época de franca prosperidade econômica, com o interesse do governo em justificar o fracasso escolar dos alunos em termos orgânicos.

Uma outra questão despertada pela pesquisa nos levou a investigar o que estaria acontecendo em nossa época com as crianças, o que revela esse número alarmante de casos de TDAH? Observamos que, na medida em que a criança transformou-se em portadora dos ideais sociais do adulto, podemos pensar que o que está em cena nessa sociedade tomada por uma lógica narcísica onipresente é o empuxo ao gozo, a satisfação plena e sem limites. Assim, como coloca Petri (2012), “o ideal de felicidade atualmente celebrado pela sociedade de consumo é francamente incompatível com a ideia de regras e limites para o gozo" (p. 151). Vetorizada por isto, a validação de um diagnóstico ofusca as questões sobre as quais o sujeito deveria se responsabilizar e que implicariam em perdas narcísicas. Assim, defendendo-se de sua própria castração, muitos pais, professores e muitas crianças aceitam o diagnóstico de TDAH para tentar "esconder de si mesmos" as dificuldades que encontram em exercer seus respectivos papéis. Nessas condições, os benefícios do diagnóstico são "exaltados", e as consequências adversas não são, realmente, levadas em conta.

Retomando, pensamos, enfim, ter podido responder à questão que nos colocamos acima, sobre a busca até insistente pelo diagnóstico do TDAH que muitos empreendem. Cremos que ela advém, em grande parte, da permeabilidade do campo educacional a certo discurso médico, que, balizado por lucros exorbitantes, incita as pessoas a identificarem o TDAH. Com base nas considerações apresentadas, percebemos que, de certa forma, a escola se tornou cúmplice desse certo saber médico, ainda que nem sempre alertada sobre as consequências de tal apoio inadvertido.

Em relação ao questionamento feito às professoras sobre o interesse e a valorização do diagnóstico de TDAH, obtivemos resultados interessantes. Foi-nos possível verificar que a interpelação da pesquisadora sobre o interesse pedagógico pelo diagnóstico propiciou, em muitas professoras, uma retificação subjetiva, graças à escuta psicanalítica sobre a qual esta pesquisa se assenta, com sua presença interrogativa no campo educativo. Por retificação subjetiva entende-se a possibilidade de uma pessoa se confrontar com o seu dizer, de reavaliar certezas e abrir-se para uma nova compreensão sobre o fenômeno, ou ainda, de poder falar a partir de uma outra posição, de um outro lugar no laço social. Frente à provocação realizada - 
em que muda para a sua prática educativa saber ou não se aquela criança tem TDAH? -, a maioria das professoras que, num primeiro momento, defendiam a importância de terem conhecimento da presença do dito transtorno, surpreenderam-se quando puderam se dar conta de que em nada mudaria a prática educativa, pois elas já desenvolviam estratégias de enfrentamento e alternativas em sala de aula que independem do mesmo.

Avancemos aqui, retomando o que foi apontado acima, com relação à percepção dessas professoras da banalização do diagnóstico entre muitas famílias que frequentam essas escolas de elite e as questões próprias à escolarização dessa classe social favorecida economicamente. De acordo com nossos achados, muitas famílias "buscam" o diagnóstico de TDAH - quando não o compram, segundo o relato de uma professora -, para que seus filhos obtenham todos os "beneficios" 47 advindos dessa nomeação: não reprovar, fazer prova adaptada, ter mais tempo que os demais colegas durante a avaliação, não ir com nota baixa. Tudo isso, como vimos, é para muitas dessas famílias mais importante do que o próprio rendimento acadêmico, pois o que mais interessa é passar de ano e obter o diploma.

Abrimos um parêntese aqui para revelar que, em algumas das escolas pesquisadas, o TDAH é considerado caso de inclusão, o que traz uma série de especificidades no trato escolar, consideradas positivas para a criança e para a família. Porém, isso traz consigo diversas consequências, quando pensamos no lugar a partir do qual a criança é falada e reconhecida e de onde responde. Conforme pudemos acompanhar na fala de algumas professoras sobre "O" TDAH, "O" desatento e "O" hiperativo, vimos como essas crianças perdem seus nomes próprios e passam a ser reconhecidas em um distúrbio. Alertamos aqui para o efeito da nomeação de um transtorno, as afirmações a respeito de uma impossibilidade e os juízos de valor, que funcionam como verdades que podem se refletir decisivamente na vida da criança. Com isso, queremos afirmar que as formações discursivas da esfera médica e educacional podem aprisionar o sujeito à dimensão imaginária de ser uma criança portadora de problema.

Um aspecto diferencial das crianças que frequentam essas escolas de elite, evidenciado no discurso das professoras, é o acesso a terceiros que medeiam a relação da criança com a família e da criança com a escola. Professores particulares, psicólogos, psicopedagogos e até a figura do "coaching educacional" são utilizados frequentemente como

\footnotetext{
${ }^{47}$ Em janeiro de 2008, a Secretaria de Educação Especial, declarou que crianças diagnosticadas com TDAH necessitam de um atendimento educacional especializado, classificando-as no grupo de transtornos funcionais específicos (assim como a dislexia, disortografia e discalculia). Frente a proposição desta lei vemos escolas altamente dependentes de certas práticas médicas.
} 
recurso não só no enfrentamento das dificuldades escolares vivenciadas pela criança, mas também em sua própria educação. Marcamos aqui um ponto importante de diferença entre a escola pública e a escola particular de elite, em relação a esse apoio em terceiros e aos recursos com os quais as crianças de escolas particulares de elite podem contar. Isso revela um privilégio de determinado grupo social em relação ao próprio processo de educação e ao chamado fracasso escolar.

Como poderíamos pensar no grupo não "privilegiado"? Os pais, na maioria das vezes, não possuem condições de pagar alguém fora da escola para ajudar a criança e também não assumem a responsabilidade pela educação dela por vários motivos. Portanto, esperam que a escola assuma a educação dos seus filhos. Segundo Cortella (2014):

A escola foi soterrada nos últimos 30 anos com uma série de ocupações que ela não dá conta e não dará. Em uma sociedade em que os adultos passaram a se ausentar da convivência com as crianças, seja por conta do excesso de trabalho, da distância nas megalópoles ou da falta de paciência para conviver com aqueles que têm menos idade, a escola ficou soterrada de tarefas. As famílias confundem escolarização com educação. É preciso lembrar que a escolarização é apenas uma parte da educação. Educar é tarefa da família. Muitas vezes, o casal não consegue, com o tempo de que dispõe, formar seus filhos e passa a tarefa ao professor, responsável por uma classe de 35 ou 40 alunos, tendo de lidar com educação artística, religiosa, ecológica, sexual, para o trânsito, contra a droga, português, matemática, história, biologia, língua estrangeira moderna, etc. ( $\mathrm{s} / \mathrm{p})$

Como já aludido na análise das entrevistas, as professoras entrevistadas se referem copiosamente à falta de limites das crianças e ao fato de os pais estarem delegando às escolas aspectos da educação de seus filhos que não competem a elas. Há, portanto, uma percepção compartilhada pelas professoras sobre a ausência de limites ofertados pelos responsáveis pela criança. Tratamos neste estudo de verificar os efeitos na escola de uma época - marcada pela valorização e hegemonia do discurso médico cientifico - em que a função paterna fraqueja e o sujeito encontra-se carente de referências.

Isso vai ao encontro do que é exposto por Forbes (2011), e apresentado no Capítulo 3, como reflexo de uma sociedade desbussolada. Muitos pais encontram-se perdidos e desorientados em sua função e parecem ter se esquecido de que ter filho dá trabalho, exige paciência e implica em frustrar e colocar limites. Se forem guiados pela lógica hedonista de uma sociedade capitalista que valoriza acima de tudo o prazer e o gozo ilimitado e infinito, ficará cada vez mais difícil às famílias disciplinar seus filhos e, com isso, acabarão passando para eles a ideia de que podem tudo. Assim, temos a desimplicação e o consequente declínio da educação de seu lugar humanizador, fatores que são cúmplices do discurso médico 
tecnocientífico e sustentados pelos adultos que deveriam zelar por aqueles seres que chegam ao mundo depois de nós (Voltolini, 2001).

Entre as entrevistadas, encontramos um exemplo de notável resistência ao discurso medicalizante sobre as manifestações da infância que parece ser comum no campo pedagógico. Clara, que ao longo de seus mais de 20 anos de formação e atuação afirma jamais ter encontrado uma criança com TDAH, tampouco ter pensado nessa hipótese frente ao comportamento de algum aluno, refere-se com grande preocupação à patologização das vicissitudes e impasses escolares. Ela considera que é papel fundamental do professor cativar o aluno e dar conta da agitação por meio de aulas envolventes, inventivas e interessantes.

Acho que os agitados vão ficando menos agitados. Acho importante o professor olhar o que tem e não o que falta. Não dá para ter alunos ideais nem a sala ideal. Você tem que trabalhar com essas crianças para elas crescerem. (Clara)

Isso nos remete a uma passagem de Freud (1932/1996), encontrada em Novas Conferências Introdutórias sobre Psicanálise, sobre a posição delicada da educação, visto que é impossível que um mesmo método seja bom para todos os sujeitos, dado suas particularidades.

A educação tem de escolher seu caminho entre o Cila da não interferência e o Caríbdis da frustração. A menos que o problema seja inteiramente insolúvel, de a educação atingir o máximo com o mínimo de dano. Será, portanto, uma questão de decidir quanto proibir, em que hora e por que meios. (p. 182)

Ainda que o autor estivesse se referindo, nesse texto, prioritariamente às práticas educacionais entre a repressão, inibidora da curiosidade intelectual, e a frustração, necessária para a manutenção da civilização, entendemos que se trata, sobretudo, da "justa medida", que deve ser encontrada pelo agente educativo por meio de um estilo singular que testemunhe um saber que o habita.

Cabe efetuar algumas considerações finais, à luz da Psicanálise, na compreensão de como a escola tem, em geral, feito eco a certo discurso médico quase hegemônico. As constatações às quais chegamos com nossa pesquisa, nos levaram a refletir sobre a permeabilidade ao discurso da ciência, seja pela compreensão organicista sobre as vicissitudes da criança seja pelos encaminhamentos realizados ou pelo ideal de uma normalização tantas vezes partilhado entre os professores. Em relação a este último aspecto, a Psicanálise pode nos acrescentar a importância de estarmos advertidos sobre esse fenômeno inconsciente, para que possamos levar em consideração o modo como isso incide sobre nós e determina nossos atos, julgamentos e pré-concepções. 
Entendemos que a maior contribuição deste trabalho encontra-se na elucidação e constatação da necessidade de debates sobre a complexidade do tema. Desejamos contribuir para a expansão do pensamento crítico sobre as questões que permeiam o diagnóstico de TDAH tão em voga atualmente. Ainda que não seja possível generalizar os resultados encontrados neste trabalho, dado o número limitado da amostra e o caráter qualitativo da pesquisa, podemos indicar que existe uma percepção médica e biologizante das dificuldades e do sofrimento das crianças. Este trabalho pretende ser um disparador para alimentar o debate, que incentive o discurso pedagógico a tentar não colaborar para a manutenção de uma lógica calcada nos valores capitalistas que acreditam que o mercado oferece aquilo que o fará saber o que fazer.

Privilegiamos destacar também os determinantes sociais que hoje se impõe como valores e se refletem não só no modo como a cultura lê as manifestações da infância, mas na própria forma como esta se apresenta. Observamos que essa "epidemia" de TDAH em nossa época está sendo engendrada por uma sociedade capitalista calcada nos lucros e na ganância e que tem como representante o poder da indústria farmacêutica.

A Psicanálise visa o resgate do sujeito na cena, possibilitando que ele se encarregue daquilo que é seu, porque enquanto estiverem fora dele os motivos e causas, supondo-se que estejam nos genes ou nos neurotransmissores, não se tem muito a intervir, a não ser mesmo com medicações que visam "fazer" funcionar melhor um organismo biológico. Na busca de soluções e respostas simples, parciais, imediatas e insuficientes, deixa-se o sujeito psíquico em uma posição de impotência e passividade frente à situação, sem desenvolver possibilidades de lidar com conflitos em um nível que envolva também o intrapsíquico e não apenas o intersubjetivo.

Acreditamos ainda que com este trabalho possamos contribuir para futuras interlocuções com os profisssionais da Educação, para que eles possam perceber as modalidades pelas quais um organismo sofre os efeitos da linguagem e a responsabilidade que possuem no enfrentamento das dificuldades escolares enfrentadas pelos alunos. Afinal, Freud (1910) já havia nos alertado que é tarefa da escola oferecer apoio e amparo aos alunos nessa época da vida que demanda o afrouxamento do vínculo com a família.

A escola nunca deve esquecer que ela tem de lidar com indivíduos imaturos a quem não se pode ser negado o direito de se demorarem no seu desenvolvimento e mesmo para alguns um pouco desagradáveis. (Freud, 1910/1996, p. 217) 


\section{REFERÊNCIAS ${ }^{48}$}

Adorno, T. W. (2006). Educação e emancipação (4a ed.). Rio de Janeiro: Paz e Terra.

Agamben, G. (2009). O que é o contemporâneo? e outros ensaios. Chapecó, SC: Editora Argos.

Agência Nacional de Vigilância Sanitária (ANVISA). Estudo aponta crescimento no consumo de metilfenidato. Recuperado em 10 de junho de 2014 de, $\mathrm{http}: / /$ portal.anvisa.gov.br/wps/wcm/connect/c4038b004e996487ada1af8a610f4177/bolet im_sngpc_2_2012+corrigido+2.pdf?MOD=AJPERES

Ajuriaguerra, J. (1973/1983). Manual de psiquiatria infantil (2a ed.). São Paulo: Masson.

Almeida, A. M. (2003). Um colégio para a elite paulista. In A. M. Almeida \& M. A. Nogueira (Orgs.), A escolarização das elites: Um panorama internacional da pesquisa (2a ed., pp. 135-174). Petrópolis, RJ: Vozes.

Almeida, A. M., \& Nogueira, M. A. (2002). A escolarização das elites: Um panorama internacional da pesquisa (2a ed.). Petrópolis, RJ: Vozes.

Akkari, A. J. (2001). Desigualdades educativas estruturais no Brasil: Entre estado, privatização e descentralização. Educação e Sociedade, 12(74), 163-189.

Arendt, H. (1957/1997). Entre o passado e o futuro. São Paulo: Perspectiva.

Ariès, P. (1960/1981). História social da criança e da família. Rio de Janeiro: LTC.

Associação Brasileira do Déficit de Atenção (ABDA). (2011). TDAH e transtorno do uso de substância. Recuperado em 10 de maio de 2014, de http://www.tdah.org.br/br/textos/textos/item/138-tdah-e-transtorno-do-uso-desubstância.html

Ballion, R. (1977). L'argent et l'école. Paris, França: Pernoud/Stock.

\footnotetext{
${ }^{48}$ De acordo com o estilo APA - American Psychological Association
} 
Barbosa, R. (1947) Reforma do ensino primário e várias instituições complementares da instrução pública. In Obras Completas (Vol. 10, t.1-4). Rio de Janeiro: Ministério da Educação e Saúde.

Barkley, R. (2002). International Consensus Statement on ADHD. Clinical Child and Family Psychology Review, 5(2). Recuperado em 29 de agosto de 2010, de http://www.russellbarkley.org/images/consensus\%202002.pdf

Bastos, M. (2005). Inclusão escolar: Inclusão dos professores? In F. A. G. Colli (Org.), Travessias inclusão escolar: A experiência do grupo ponte Pré-escola terapêutica Lugar de Vida (pp. 133-149). São Paulo: Casa do Psicólogo.

Bauman, Z. (1998). Globalization: The human consequences. New York: Columbia Univesity Press.

Baughman, F. A. (2006). The ADHD fraud: How psychiatry makes "patients" of normal children. Oxford, UK: Traffoed Publishing

Bekerman, J. (2011). Não há classificação que não seja arbitrária e conjuntural. In A. Jerusalinsky \& S. Fendrik (Orgs.), O livro negro da psicopatologia contemporânea (pp. 23-29). São Paulo: Via Lettera.

Bello, J. L. P. (2001), História da Educação no Brasil, recuperado em 9 de abril de 2014, de http://www.pedagogiaemfoco.pro.br/heb14.htm

Bernardino, L. M. F. (2006). A abordagem psicanalítica do desenvolvimento infantil e suas vicissitudes. In L. M. F. Bernardino (Org.), O que a Psicanálise pode ensinar sobre a criança, sujeito em constituição (pp. 19-43). São Paulo: Escuta.

Birman, J. (1999). Mal-estar na atualidade: A Psicanálise e as novas formas de subjetivação. Rio de Janeiro: Civilização Brasileira.

Bordieu, P. (1998). A Escola conservadora: as desigualdades frente à escola e à cultura. In M. A. Nogueira \& A. Catani (Orgs.), Escritos de educação: Pierre Bordieu (pp. 39-64). Petrópolis, RJ: Vozes.

Brandão, Z., \& Lellis, I. (2003). Elites acadêmicas e escolarização dos filhos. Educação e Sociedade. São Paulo: Cortez, 24(83), 509-526. 
Bregguin, P. (2002). The ritalin fact book: What your doctor won't tell you about ADHD and stimulant drugs. Cambridge, MA: Perseus Group Book.

Caliman, L. V. (2008, setembro). O TDAH: entre as funções, disfunções e otimização da atenção. Psicologia em estudo, 13(3), 559-566. Recuperado em 9 de junho de 2010, de http://www.scielo.br/scielo.php?script=sci_arttext\&pid=S1413$73722008000300017 \& \operatorname{lng}=$ pt\&nrm=iso

Caliman, L. V. (2009). A constituição sócio-médica do "fato TDAH". Psicologia e Sociedade, 21(1), 135-144. Recuperado em 9 de junho de 2010, de http://www.scielo.br/scielo.php?script=sci_arttext\&pid=S010271822009000100016\&lng $=$ pt\&nrm $=$ iso

Caliman, L. V. (2010). Notas sobre a história oficial do transtorno de déficit de atenção/hiperatividade TDAH. Psicologia Ciência e Profissão, 30(1), 45-61. Recuperado em 20 de junho de 2014, de http://www.scielo.br/scielo.php?script=sci_arttext\&pid=S1414-98932010000100005

Caminha, E. M. S. (2006). Panorama histórico de 500 anos de educação no Brasil. Monografia, Universidade Candido Mendes, Rio de Janeiro.

Cattani, A. D., \& Kieling, F. S. (2007). A escolarização das classes abastadas. Sociologia (Porto Alegre), 9(18), 170-187.

Cauvilla, W. (1999). Sobre um momento da constituição da ideia de infância: Ponto de vista de um historiador. Estilos da Clínica, 4(6), 72-79. Recuperado em 30 de março de 2014, de http://pepsic.bvsalud.org/scielo.php?script=sci_arttext\&pid=S1415$71281999000100007 \& \operatorname{lng}=\mathrm{pt} \& \operatorname{lng}=\mathrm{pt}$

Chauí, M. S. (2010). Convite à filosofia. (3a ed.). São Paulo: Ática.

Collares, C. A. L., \& Moysés, M. A. A. (1996). A história não contada dos distúrbios de aprendizagem. Caderno Cedes, 28, 31-47.

Collares, C. A. L., \& Moysés, M. A. A. (1997). Inteligência abstraída, crianças silenciadas: as avaliações de inteligência. Revista Psicologia USP, 8(1), 63-89. Recuperado em 10 de junho de 2011, de http://www.scielo.br/scielo.php?pid=S0103$65641997000100005 \&$ script $=$ sci_arttext 
Collares, C. A. L., \& Moysés, M. A. A. (2011). Dislexia e TDAH: uma análise a partir da ciência médica. In Conselho Regional de Psicologia de São Paulo, Grupo Interinstitucional Queixa Escolar (Org.), Medicalização de crianças e adolescentes: conflitos silenciados pela redução de questões sociais a problemas de indivíduos (pp. 71110). São Paulo: Casa do Psicólogo.

Cortella, M. S. (2014, 17 de maio). A escola passou a ser vista como um espaço de salvação. O Estado de São Paulo, entrevista Bia Reis.

Costa, J. F. (1989). Ordem médica e norma familiar. Rio de Janeiro: Graal.

Coutinho, G., Mattos, P., Schmitz, M., Fortes, D., \& Borges, M. (2009). Concordância entre relato de pais e professores para sintomas de TDAH: resultados de uma amostra clínica brasileira. Revista de psiquiatria clínica, 36(3), 97-100. Recuperado em 27 de maio de 2010 , de http://www.scielo.br/scielo.php?script=sci_arttext\&pid=S010160832009000300003\&lng $=$ pt\&nrm $=$ iso

Cortella, M. S. (2002). A escola e o conhecimento: Fundamentos epistemológicos e políticos. (6a ed.). São Paulo: Cortez.

Cunha, A. S. (2012). Famílias não tradicionais e problemas na escola. In M. R. Pereira (Org.), A Psicanálise escuta a educação: 10 anos depois (pp. 109-122). Belo Horizonte, MG: Fino Traço.

Dallabrida, N. (2001). A fabricação escolar das elites: O ginásio catarinense na Primeira República. Florianópolis, SC: Cidade Futura.

Del Priore, M., \& Venâncio, R. (2010). Uma breve história do Brasil. São Paulo: Planeta do Brasil.

DSM V (2013). Manual Diagnóstico e estatístico de transtornos mentais. Recuperado em 10 de abril de 2014, de http://www.dsm5.org/Pages/Default.aspx

Fernandéz, A. (2001). Os idiomas do aprendente: Análise das modalidades ensinantes com famílias, escolas e meios de comunicação. Porto Alegre, RS: Artes Médicas.

Forbes, J. F. (2010). Inconsciente e responsabilidade. Tese de doutorado em Psicologia, Programa de Pós-Graduação em Psicanálise, Universidade Federal do Rio de Janeiro. 
Forbes, J. F. (2012). Inconsciente e responsabilidade: Psicanálise do século XXI. São Paulo: Manole.

Foucault, M. (1997). A arqueologia do saber. Rio de Janeiro: Forense Universitária.

Freire, A. B. (2007). Apostar no sintoma. Rio de Janeiro: Contra Capa Livraria.

Freitas, M. C., \& Kuhlmann, M. J. (2002). Os intelectuais na história da infância. São Paulo: Cortez.

Freud, S. (1897/1996). Extratos dos documentos dirigidos a Fliess - Carta 69. In Edição Standard Brasileira das obras psicológicas completas de Sigmund Freud (J. Salomão, trad., Vol. I, pp. 69-91). Rio de Janeiro: Imago.

Freud, S. (1905/1996). Três ensaios sobre a teoria da sexualidade. In Edição Standard Brasileira das obras psicológicas completas de Sigmund Freud (J. Salomão, trad., Vol. VII, pp. 13-92). Rio de Janeiro: Imago.

Freud, S. (1908a/1996). Um estudo autobiográfico. In Edição Standard Brasileira das obras psicológicas completas de Sigmund Freud (J. Salomão, trad., Vol. XX, pp. 13-92). Rio de Janeiro: Imago.

Freud, S. (1908b/1996). Sobre as teorias sexuais infantis. In Edição Standard Brasileira das obras psicológicas completas de Sigmund Freud (J. Salomão, trad., Vol. IX, pp.187-204). Rio de Janeiro: Imago.

Freud, S. (1910/1996). Contribuições para uma discussão acerca do suicídio. In Edição Standard Brasileira das obras psicológicas completas de Sigmund Freud (J. Salomão, trad., Vol. XI, pp. 243-45). Rio de Janeiro: Imago.

Freud, S. (1911/1996). Formulações sobre os dois princípios do funcionamento mental. In Edição Standard Brasileira das obras psicológicas completas de Sigmund Freud (J. Salomão, trad., Vol. XII, pp.273-288). Rio de Janeiro: Imago.

Freud, S. (1913/1996). Totem e Tabu. In Edição Standard Brasileira das obras psicológicas completas de Sigmund Freud (J. Salomão, trad., Vol. XIII, pp. 199-216. Rio de Janeiro: Imago. 
Freud, S. (1914a/1996). Sobre o narcisismo: uma introdução. In Edição Standard Brasileira das obras psicológicas completas de Sigmund Freud (J. Salomão, trad., Vol. XIV, pp. 85-119). Rio de Janeiro: Imago.

Freud, S. (1914b/1996). Recordar, repetir e elaborar. In Edição Standard Brasileira das obras psicológicas completas de Sigmund Freud (J. Salomão, trad., Vol. XII, pp. 161-171). Rio de Janeiro: Imago.

Freud, S. (1914c/1996). Algumas reflexões sobre a psicologia do escolar. In Edição Standard Brasileira das obras psicológicas completas de Sigmund Freud (J. Salomão, trad., Vol. XIII, pp. 285-288). Rio de Janeiro: Imago.

Freud, S. (1915/1996). A pulsão e seus destinos. In Edição Standard Brasileira das obras psicológicas completas de Sigmund Freud (J. Salomão, trad., Vol. XIV, pp. 85-119). Rio de Janeiro: Imago.

Freud, S. (1916-17/1996). Conferência XXIII. Os caminhos da formação dos sintomas. In Edição Standard Brasileira das obras psicológicas completas de Sigmund Freud (J. Salomão, trad., Vol. XVI, pp. 265-279). Rio de Janeiro: Imago.

Freud, S. (1917/1996). Conferência XVIII - Fixação em Traumas - O Inconsciente. In Edição Standard Brasileira das obras psicológicas completas de Sigmund Freud (J. Salomão, trad., Vol. XVI, pp. 265-281). Rio de Janeiro: Imago.

Freud, S. (1924-25/1976). Um estudo autobiográfico. In Edição Standard Brasileira das obras psicológicas completas de Sigmund Freud (J. Salomão, trad., Vol. XX pp. 13-92). Rio de Janeiro: Imago.

Freud, S. (1930/1996). O mal-estar na civilização. In Edição Standard Brasileira das obras psicológicas completas de Sigmund Freud (J. Salomão, trad., Vol. XXI, pp. 65-149). Rio de Janeiro: Imago.

Freud, S. (1932/1996). Novas Conferências Introdutórias sobre Psicanálise. In Edição Standard Brasileira das obras psicológicas completas de Sigmund Freud (J. Salomão, trad., Vol. XX, pp. 191-270). Rio de Janeiro: Imago.

Freud, S. (1937/1996). Análise terminável e interminável. In Edição Standard Brasileira das obras psicológicas completas de Sigmund Freud (J. Salomão, trad., Vol. XXIII, pp. 224270). Rio de Janeiro: Imago. 
Freud, S. (1940/1996). Esboço de Psicanálise. In Edição Standard Brasileira das obras psicológicas completas de Sigmund Freud (J. Salomão, trad., Vol. XXIII, pp. 168-246). Rio de Janeiro: Imago.

Garcia, R. (2012, 31 de março). Indústria influencia manual de psiquiatria: cresce influência da indústria sobre manual de psiquiatria. Jornal Folha de São Paulo, Caderno Cotidiano/Saúde, p. 8.

Garcia-Roza, L. A. (2005). Freud e o inconsciente (21a ed.). Rio de Janeiro: Jorge Zahar.

Gorostiza, L. (dez. 2007). O pai e a autoridade. Opção Lacaniana: Revista Brasileira Internacional de Psicanálise, 50, 75-79.

Guarido, R. (2007). A medicalização do sofrimento psíquico: considerações sobre o discurso psiquiátrico e seus efeitos na Educação. Educação e Pesquisa, 33(1), 151-161. Recuperado em 18 de março de 2010, de http://www.scielo.br/scielo.php?script=sci_arttext\&pid=S151797022007000100010@lng=pt\&nrm=iso

Guarido, R. (2008). O que não tem remédio, remediado está: medicalização da vida e algumas implicações da presença do saber médico na educação. Dissertação de Mestrado, Faculdade de Educação, Universidade de São Paulo.

Guarido, R. (2011). A biologização da vida e algumas implicações do discurso médico sobre a educação. In Conselho Regional de Psicologia de São Paulo, Grupo Interinstitucional Queixa Escolar (Org.), Medicalização de crianças e adolescentes: conflitos silenciados pela redução de questões sociais a doenças de indivíduos (pp. 27-41). São Paulo: Casa do Psicólogo.

Heywood, C. (2004). Uma história da infância: Da Idade Média à época contemporânea no Ocidente. Porto Alegre: Artmed.

Houaiss, A. (2002). Sintoma. Dicionário eletrônico da Língua Portuguesa. Rio de janeiro: Objetiva

Houaiss, A. (2002). Sinal. Dicionário eletrônico da Língua Portuguesa. Rio de janeiro: Objetiva

Instituto Brasileiro de Defesa dos Usuários de Medicamentos (IDUM). Recuperado em 4 de abril de 2014, de http://www.idum.org/site/index.php 
Infante, D. P. (2011). Psiquiatria para que e para quem? In A. Jerusanlinsky \& Fendrik, S. (Orgs.), O livro negro da psicopatologia contemporânea (pp. 63-73). São Paulo: Via Lettera.

Jorge, M. A. C., \& Bastos, F. C. P. (2014). Trabalho e capitalismo: uma visão psicanalítica, 21-33 Recuperado em 29 de maio de 2014, de http://www.uva.br/trivium/edicao1/artigostematicos/2-trabalho-e-capitalismo.pdf

Kamers, M. (2013). A fabricação da loucura na infância: psiquiatrização do discurso e medicalização da criança. Revista Estilos da Clínica, 18(1), 153-165. Recuperado em 29 de maio de 2014, de http://pepsic.bvsalud.org/scielo.php?script=sci_arttext\&pid=S $15-71282013000100010 \& \operatorname{lng}=\mathrm{pt} \& \mathrm{tlng}=\mathrm{pt}$

Kupermann, D. (2011). A criança, o infantil e o que o psicanalista (não) sabe. Revista Estilos da clínica: o declínio dos saberes, 16(2), 324-337.

Kupfer, M. C. (2007). Educação para o futuro: Psicanálise e educação. São Paulo: Escuta.

Kupfer, M. C., \& Bernardino, L. M. F. (2009). As relações entre construção da imagem corporal, função paterna e hiperatividade: Reflexões a partir da Pesquisa IRDI. Revista Latinoamericana de Psicopatologia Fundamental, 12(1), 45-58. Recuperado em 27 de maio de 2010, de http://www.scielo.br/scielo.php?script=sci_arttext\&pid=S1415$47142009000100004 \& \operatorname{lng}=$ pt\&nrm=iso

Kupfer, M. C. (2011). Educação terapêutica para crianças com transtornos globais do desenvolvimento: uma alternativa à medicalização da educação. In A. Jerusanlinsky \& S. Fendrik (Orgs.), O livro negro da psicopatologia contemporânea (pp.141-161). São Paulo: Via Lettera.

Lacan, J. (1953/1998). Função e campo da fala e da linguagem em Psicanálise. In J. Lacan, Escritos (pp. 238-324). Rio de Janeiro: Jorge Zahar.

Lacan, J. (1972). Du discours psychanalytique. Conférence à l'université de Milan. Recuperado em 20 de dezembro de 2011, de http://pagespersoorange.fr/espace.freud/topos/psycha/psysem/italie.htm

Lacan, J. (1969-70/1992). O seminário, livro 17: O avesso da Psicanálise. Rio de Janeiro: Jorge Zahar.

Lacan, J. (1972-73/1992a). O seminário, livro 20: Mais, ainda. Rio de Janeiro: Jorge Zahar. 
Lacan, J. (1972-73/1992b). O seminário, livro 23. O Sinthoma. Rio de Janeiro: Jorge Zahar.

Lacan, J. (1964/1998). O seminário, livro 11. Os quatro conceitos fundamentais de Psicanálise. Rio de Janeiro: Jorge Zahar.

Lacan, J. (1966/1998). A ciência e a verdade. Escritos. Rio de Janeiro: Jorge Zahar. (pp. 869892).

Lacan, J. (1978/1998). Função e campo da fala e da linguagem em Psicanálise. In: Escritos. São Paulo: Perspectiva.

Lacan, J. (1957/1999). O seminário, livro 5. As formações do inconsciente. Rio de Janeiro: Jorge Zahar.

Lajonquière, L. (1997). Dos erros e em especial daquele de renunciar à educação. Estilos da Clínica, 2(2), 27-43.

Lajonquière, L. (1999). Infância e ilusão (psico)pedagógica: Escritos de Psicanálise e educação. Petrópolis, RJ: Vozes.

Lajonquière, L. (2003). A infância que inventamos e as escolas de ontem e de hoje. Estilos da Clínica, 8(15), 140-159.

Lajonquière, L. (2006). A Psicanálise e o debate sobre o desaparecimento da infância. Educação \& Realidade, 3, 89-106. Recuperado em 10 de junho de 2014, de http://www3.fe.usp.br/secoes/inst/novo/laboratorios/lepsi/biblioteca/estante/01.pdf

Lajonquière, L. (2010). As figuras do infantil. Petrópolis, RJ: Vozes.

Laurent, E. (2004). Desangustiar? Revista Digital de la escuela de Orientacion Lacaniana, 11/12, 21-23. Recuperado em 2 de setembro de 2010, de http://virtualia.eol.org.ar/012/default.asp?notas/laurent-01.html

Laplanche, J., \& Pontalis J. B. (2001). Vocabulário da Psicanálise. Lisboa: Moraes.

Legnani, V., \& Almeida, F. (2008). A construção diagnóstica de Transtorno de Déficit de Atenção/Hiperatividade: Uma discussão crítica. Arquivo brasileiro de psicologia , 60(1), 
2-13. Recuperado em 21 de maio de 2010, de http://pepsic.bvsalud.org/scielo.php?script=sci_arttext\&pid=S1809-

$52672008000100002 \& \operatorname{lng}=$ es\&nrm=iso

Lei Geral do Ensino, de 15 de outubro de 1827 (1827, 15 de outubro). Manda criar escolas de primeiras letras em todas as cidades, vilas e lugares mais populosos do Império. Recuperado em 20 de junho de 2014, de http://www.planalto.gov.br/ccivil_03/Leis/LIM/LIM-15-10-1827.htm

Lei n ${ }^{\circ}$ 9.394, de 20 de dezembro de 1996. (1996, 23 de dezembro). Estabelece as Diretrizes e Bases da Educação Nacional. Diário Oficial da União, seção 1.

Lipovetsky, G. (2005). A era do vazio: Ensaios sobre o individualismo contemporâneo. São Paulo: Manole.

Lloyd, G., Stead, J., \& Cohen, D. (2007). Critical new perspectives on ADHD. New York: Routledge.

Lutero, M. (1530/1995). Uma prédica para que se mandem os filhos à escola [1530]. In: . Martinho Lutero: Obras selecionadas (Vol. 5, pp. 326-363) São Leopoldo: Comissão Interluterana de Literatura.

Mannoni, M. (1977). A criança atrasada e a mãe. (2a ed). Lisboa: Moraes.

Marcelli, D. (1982/1998). Manual de psicopatologia da infância de Ajuriaguerra (5ª ed.). Porto Alegre: Artmed.

Marino, A. S., \& Baptista, M. T. D. S. (2007). A história como paradigma na construção de sujeitos de direitos. Mnemosine, 3(2), 194-221.

Melman, C. (2009). Que espera o adolescente da sexualidade e da morte? In C. Melman (Org.), Adolescente, sexo e morte (pp. 129-143). Porto Alegre: CMC.

Mezan, R. (2008). Freud: A trama dos conceitos (4a ed.). São Paulo: Perspectiva.

Ministério de Educação e do Desporto. (1998). Referencial curricular nacional para educação infantil. Brasília, DF: MEC. 
Monteiro, H. R. (2008, outubro). Construindo saúde: a dimensão do sofrimento docente Salto para o futuro [Edição especial: Saúde do professor em questão]. 19, pp. 3-9 Recuperado em 18 de junho de 2014, de http://www.tvbrasil.org.br/fotos/salto/series/182457Saudeprof.pdf

Moretto, M. L. T. (2006). O psicanalista num programa de transplante de fígado: A experiência do "Outro em si". Tese de Doutorado em Psicologia Clínica, Instituto de Psicologia, Universidade de São Paulo.

Mousnier, R. (1957). Os séculos XVI e XVII: Os progressos da civilização européia. São Paulo: Difusão Européia do Livro.

Mrech, L. M. (2005). O impacto dos Terceiro Ensino de Lacan: Novas contribuições para algumas articulações possíveis entre Psicanálise e Educação. In L. M. Mrech (Org.), $O$ impacto da Psicanálise na Educação (pp. 143-159). São Paulo: Avercamp.

Mrech, L. M., Sanada, E. R., Nubile, M. V., \& Valione, Y. (2008). A criança na contemporaneidade: Sujeito ou objeto? Trabalho apresentado no $7^{\circ}$ Colóquio do Lepsi, IP/FE-USP, São Paulo. Recuperado em 2 de outubro de 2011, de http://www.proceedings.scielo.br/scielo.php?pid=MSC0000000032008000100046\&scrip $\mathrm{t}=$ sci_arttext\&tlng $=\mathrm{PT}$

Moysés, M. A. A. (1992). Fracasso escolar: Uma questão médica? Série Idéias, 6, 29-31. São Paulo: FDE. Recuperado em 9 de abril de 2011, de http://www.crmariocovas.sp.gov.br/amb_a.php?t=007

Nasio, J.-D. (1993). Cinco lições sobre a teoria de Jacques Lacan. Rio de Janeiro: Jorge Zahar.

Nasio, J.-D. (1997). Lições sobre os sete conceitos cruciais da Psicanálise. Rio de Janeito: Jorge Zahar.

National Institute of Mental Health (1998). Diagnosis and treatment of Attention Deficit Hyperactivity Disorder. Consens Statement,16-18, 16(2), 1-37. Recuperado em 20 de agosto de 2010, de http://consensus.nih.gov/1998/1998Attention DeficitHyperactivityDisorder110html.htm

Nogueira, M. A. (2003). Estratégias de escolarização em famílias de empresários. In A. M. Almeida \& M. A. Nogueira (Orgs.), A escolarização das elites: Um panorama internacional de pesquisa (2a ed., pp. 49-65). Petrópolis, RJ: Vozes. 
Nogueira, M. A. (2004). Favorecimento econômico e excelência escolar: Um mito em questão. Revista Brasileira de Educação, 26, 133-144.

Nogueira, M. A. (2010). Classes médias e escola: novas perspectivas de análise. Currículo sem Fronteiras, 10(1), 213-231.

Nogueira, C. M., \& Nogueira, M. A. (2002). A sociologia de Pierre Bordieu: Limites e contribuições. Educação e Sociedade, 23(78), 15-35. Recuperado em 10 de junho de 2014 , http://www.scielo.br/scielo.php?script=sci_arttext\&pid=S010173302002000200003

Nominé, B. (1997). O sintoma e a família: Conferências belohorizontinas. Belo Horizonte, MG: Escola Brasileira de Psicanálise.

Oliveira, M. M. (2004). As origens da educação no Brasil: Da hegemonia católica às primeiras tentativas de organização do ensino. Ensaio: aval. pol. públ. Educ., 12(45), 945-958.

Patto, M. H. S. (1990). A produção do fracasso escolar. São Paulo: T. A. Queiroz.

Patto, M. H. S. (1997). Para uma crítica da razão psicométrica. Revista Psicologia USP, 8(1), 47-62. São Paulo: Instituto de Psicologia, Universidade de São Paulo.

Patto, M. H. S. (2002). A produção do fracasso escolar: Histórias de submissão e rebeldia (2a ed.). São Paulo: Casa do Psicólogo.

Pereira, M. R. (2008). A impostura do mestre. Belo Horizonte: Argvmentvm.

Pereira, M. R. (2011). As crianças de hoje são mais sabidas. In Revista Estilos da Clínica: o declínio dos saberes, 16(2), 338-347. São Paulo: USP-IP.

Pereira, M. R. (2012). A orientação clínica como questão de método à psicologia, Psicanálise e educação. In M. R. Pereira (Org.), A Psicanálise escuta a educação: 10 anos depois (pp. 23-34). Belo Horizonte, MG: Fino Traço/FAPEMIG.

Petitat, A. (1994). Produção da escola/produção da sociedade: Análise sócio-histórica de alguns momentos decisivos da evolução escolar no ocidente. Porto Alegre: Artes Médicas. 
Petri, R. (2000). O lugar do profissional no tratamento institucional da criança psicótica: Analista ou educador? Dissertação de Mestrado, Instituto de Psicologia, Universidade de São Paulo.

Petri, R. (2008). Os impasses psíquicos na contemporaneidade e suas implicações no processo ensino/aprendizagem. Trabalho apresentado no $7^{\circ}$ Colóquio do Lepsi, IP/FEUSP, São Paulo. Recuperado em 10 de junho de 2012, de http://www.proceedings.scielo.br/scielo.php?pid=MSC0000000032008000 100072\&script $=$ sci_arttext

Postman, N. (1999). O desaparecimento da infância. Rio de Janeiro: Graphia.

Prensky, M. (2001). Digital Natives Digital Immigrants. In M. Prensky On the horizon. NCB University Press, 9(5). Recuperado em 10 de abril de 2014, de http://www.marcprensky.com/writing/

Priszkulnik, L. (2000). Clínica(s): Diagnóstico e Tratamento. Psicologia USP, 11(1), 11 28. Recuperado em 18 de abril de 2010 de, http://www.scielo.br/scielo.php?script=sci_arttext\&pid=S0103$65642000000100002 \& \operatorname{lng}=$ pt\&nrm $=$ iso

Priszkulnik, L. (2008). Prevenção: saúde mental e Psicanálise. Trabalho apresentado no $7^{\circ}$ Colóquio do Lepsi, IP/FE-USP, São Paulo. Recuperado em 2 de maio de 2014, de http://www.proceedings.scielo.br/scielo.php?script=sci_arttext\&pid=MSC000000003200 $8000100002 \& \operatorname{lng}=$ en\&nrm=abn

Priszkulnik, L. (2009). A criança que a Psicanálise freudiana descortina: considerações. In Dante de Rose Junior (Org.), Esporte e atividade fisica na infância e na adolescência: Uma abordagem multidisciplinar (2a ed., pp. 11-22). Porto Alegre, RS: ARTMED.

Quinet, A. (2009). Psicose e laço social: Esquizofrenia, paranóia e melancolia (2a ed.). Rio de Janeiro: Jorge Zahar.

Rafalovich, A. (1970/2008). Framing ADHD children: A critical examination of the history, discourse and everyday experience of Attention Deficit/Hiperactivity Disorder. United Kingdom: Lexington Books.

Rebasa, S. (2006). De la respuesta farmacológica al sintoma analítico. In G. Stiglitz (Org.), $D D A$, ADD, ADHD, como ustedes quieran: El mal estar y la construcción social (pp. 8390). Buenos Aires: Grama Ediciones. 
Rohde, L. A., \& Benczik, E. (1999). Transtorno de Déficit de Atenção e Hiperatividade: O que é? Como ajudar? Porto Alegre: Artes Médicas.

Roudinesco, E. (2000). Por que a Psicanálise? Rio de Janeiro: Jorge Zahar.

Roudinesco, E. \& Plon, M. (1998). Dicionário de Psicanálise. Rio de Janeiro: Jorge Zahar.

Santiago, A. L. (2005). Inibição intelectual na Psicanálise. Rio de Janeiro: Jorge Zahar.

Santos, C. (2008). O lugar de criança é na escola: Lutero e sua contribuição para a educação do século XVI. Monografia, Universidade do Paraná.

Saviani, D. (2006). O legado educacional do "longo século XX" brasileiro. In D. Saviani et al., O legado educacional do século XX no Brasil (pp. 9-58). Campinas, SP: Autores Associados.

Scliar, M. (2007). História do conceito de saúde. Physis: Revista de Saúde Coletiva, 17(1), 29-41. Recuperado em 27 de maio de 2010, de http://www.scielo.br/scielo.php?script=sci_arttext\&pid=S0103$73312007000100003 \& \operatorname{lng}=$ pt\&nrm=iso

Smolka, A. L. B. (2002). Estatuto de sujeito, desenvolvimento humano e teorização sobre a criança. In M. C. Freitas \& M. J. Kuhlmann (Orgs.), Os intelectuais na história da infância (pp. 7-9). São Paulo: Cortez.

Soneville, J. J. (1992). Maria Luiza Marcílio: História da escola em São Paulo e no Brasil um clássico na literatura sobre educação. Revista da FAEEBA - Educação $e$ Contemporaneidade, 1(1), pp.103-113

Souza, M. P. R. (2004). A queixa escolar e o predomínio de uma visão de mundo. In A. Machado \& M. P. R. Souza (Orgs.), Psicologia escolar: Em busca de novos rumos (pp. 19-39). São Paulo: Casa do Psicólogo.

Souza, M. P. R. (2011). Retornando à patologia para justificar a não aprendizagem escolar: A medicalização e o diagnóstico de transtorno de aprendizagem em tempos de neoliberalismo. In Conselho Regional de Psicologia de São Paulo, Grupo Interinstitucional Queixa Escolar (Orgs.), Medicalização de crianças e adolescentes: Conflitos silenciados pela redução de questões sociais a doenças de indivíduos (pp. 5769). São Paulo: Casa do Psicólogo. 
Souza, R. F. (2004). Lições da escola primária. In D. Saviani et al. O legado educacional do século XX no Brasil (pp. 35-84). Campinas, SP: Autores Associados.

St-Onge, J. C. (2013, 23 de maio). Estamos todos loucos? A influência da indústria farmacêutica sobre a Psiquiatria. Blog Direito Sanitário: Saúde e Cidadania.

Stiglitz, G. (2006). La clase de los DDA o la rebelion de las singularidades. In G. Stiglitz (Org.), DDA, ADD, ADHD, como ustedes quieran: El mal estar y la construcción social (pp. 11-18). Buenos Aires: Grama Ediciones.

Tallis, J. (2006). La medicación desresponsabiliza. In G. Stiglitz (Org.), $D D A, A D D, A D H D$, como ustedes quieran: El mal estar y la construcción social (pp. 35-42). Buenos Aires: Grama Ediciones.

Tendlarz, S. E. (2006). La atención que falta y la actividad que sobra: reflexiones sobre el ADD. In G. Stiglitz (Org.), DDA, ADD, ADHD, como ustedes quieran: El mal estar y la construcción social (pp. 75-82). Buenos Aires: Grama Ediciones.

Turato, E. R. (2010). Tratado de metodologia da pesquisa clínico-qualitativa: Construção teórico-epistemológica, discussão comparada e aplicação nas áreas da saúde e humanas (4a ed.). Petrópolis, RJ: Vozes.

Voltolini, R. (2001). Do contrato pedagógico ao ato analítico: Contribuições à discussão da questão do mal-estar na educação. Revista Estilos da Clínica, 6(10), 101-111.

Voltolini, R. (2008). A escola e os profissionais d'A criança. Trabalho apresentado no $7^{\circ}$ Colóquio do Lepsi, IP/FE-USP, São Paulo. Recuperado em 2 de outubro de 2011, de http://www.proceedings.scielo.br/scielo.php?pid=MSC0000000032008000100012\&scrip $\mathrm{t}=$ sci_arttext

Voltolini, R. (2011a). Educação sem sociedade. In L. M. Mrech \& M. R. Pereira (Orgs.), Psicanálise, transmissão e formação de professores (pp. 35-47). Belo Horizonte, MG: Fino Traço.

Voltolini, R. (2011b). Educação e Psicanálise. Rio de Janeiro: Zahar. 
Voltolini, R. (2012). O conhecimento e o discurso do capitalista: a despsicologização do cotidiano social. Revista Estilos da Clínica, 17(1), 106-121. Recuperado em 16 de junho de 2014, de http://pepsic.bvsalud.org/pdf/estic/v17n1/v17n1a08.pdf

Vorcaro, A. (2011). O efeito bumerangue da classificação psicopatológica da infância. In A. Jerusalinsky \& S. Fendrik (Orgs.), O livro negro da psicopatologia contemporânea (pp. 219-231). São Paulo: Via Lettera.

Werner, J. (2001). Saúde e educação: Desenvolvimento e aprendizagem do aluno. Rio de Janeiro: Gryphusin.

Zelmanovich P. (2014). A equação família-escola: Entre o reenvio da impotência e a dialética alienação e separação. In R. Voltolini (Org.), Retratos do mal-estar contemporâneo na educação (pp. 181-195). São Paulo: Escuta. 


\section{ANEXO \\ Termo de Consentimento Livre e Esclarecido}

(De acordo com a Resolução 196/96 do Conselho Nacional de Saúde)

Eu, Marianna da Gama e Silva, estou realizando uma pesquisa que pretende analisar os sentidos e significações atribuídos por professores ao diagnóstico de TDAH. Nesta pesquisa, o(a) professor(a) será convidado(a) a participar através de uma entrevista, de modo que possa falar sobre a sua experiência com estes casos. O(a) professor(a) poderá participar desta pesquisa mediante este termo de consentimento livre e esclarecido.

Serão modificados, em todas as circunstâncias, os dados pessoais entre outras informações de identificação do(a) entrevistado(a) e da Instituição onde trabalha. As informações serão preservadas durante a inclusão dos dados das entrevistas e na análise de resultados. Os dados obtidos serão utilizados em uma dissertação de Mestrado, no Instituto de Psicologia da Universidade de São Paulo (IPUSP), em eventos científicos e em publicações em periódicos científicos.

As entrevistas, previamente agendadas, serão realizadas fora do ambiente de trabalho do entrevistado, em recinto preservado. A entrevista será gravada, e terá a duração de, aproximadamente, uma hora. Ao término da pesquisa, o material gravado será inutilizado. $\mathrm{O}(\mathrm{a})$ professor(a) poderá solicitar quaisquer informações que achar necessário e poderá retirar seu consentimento a qualquer momento sem penalidades. $\mathrm{O}(\mathrm{a})$ professor(a) poderá se recusar a falar sobre qualquer assunto que julgar necessário e poderá não autorizar a utilização total ou parcial dos dados. 
$\mathrm{O}(\mathrm{a})$ professor(a) poderá entrar em contato com a pesquisadora através do telefone (11) 99406-1136 ou por e-mail mariannagesilva@gmail.com a qualquer momento desta pesquisa ou posterior a ela. $\mathrm{O}(\mathrm{a})$ professor(a) terá a disposição uma cópia deste documento.

$\mathrm{Eu}$, $\mathrm{RG} \mathrm{n}^{\mathrm{o}}$

após tomar ciência da proposta desta pesquisa, através da pesquisadora responsável e ratificado no texto acima, considero-me plenamente esclarecido(a), sabendo que poderei, a qualquer momento, rever esta posição e solucionar dúvidas. Estou de acordo com a minha participação, como voluntário(a), nesta pesquisa e dou permissão para ser entrevistado(a) e para estas entrevistas serem transcritas em papel.

São Paulo,

Assinatura do professor

Assinatura da pesquisadora

-Comitê de Ética em Pesquisa com Seres Humanos do Instituto de Ciências Biomédicas da USP. Prof. Lineu Prestes, 2415, Cidade Universitária, São Paulo, SP. Tel. (11) 3091-7733.

- Orientadora da pesquisa: Prof.a. Dra. Léia Priszkulnik. Departamento de Psicologia Clínica do Instituto de Psicologia da USP. Tel. (11) 3091-4173. 